UNIVERSIDADE DE SÃO PAULO

FACULDADE DE EDUCAÇÃO

\title{
A PRÁTICA DOCENTE DO PROFESSOR DE FÍSICA DO TERCEIRO GRAU
}

AGUIDA CELINA DE MÉO BARREIRO

1996 
UNIVERSIDADE DE SÃO PAULO

FACULDADE DE EDUCAÇÃO

\section{A PRÁTICA DOCENTE DO PROFESSOR DE FÍSICA DO TERCEIRO GRAU}

AGUIDA CELINA DE MÉO BARREIRO

Tese apresentada à Faculdade de Educação, da Universidade de São Paulo, para obtenção do título de Doutor em Educação, área de concentração Didática, sob a orientação do

Prof. Dr. Marcos Tarciso Masetto 


\section{SUMÁRIO}

\section{RESUMO}

\section{ABSTRACT}

1. INTRODUÇÃO

2. RECUPERANDO UM POUCO DA HISTÓRIA 18

2.1 O CAMPUS DA USP EM SÃO CARLOS 18

2.2. O INSTITUTO DE FÍSICA DE SÃO CARLOS 23

2.3 BACHARELADO EM FÍSICA 31

2.4 LICENCIATURA DIURNA EM FÍSICA 32

2.5 LICENCIATURA NOTURNA EM CIÊNCIAS EXATAS 41

3. REPENSANDO A PRÁTICA DOCENTE 46

4. OS CAMINHOS DA INVESTIGAÇÃO 100

5. DA PRÁTICA AO RELATO 113

6. A BUSCA DE SIGNIFICADOS: que caminhos se abrem? 173

$\begin{array}{lr}\text { 7. BIBLIOGRAFIA } & 188\end{array}$

$\begin{array}{ll}\text { ANEXO 1 } & 195\end{array}$

$\begin{array}{lr}\text { ANEXO 2 } & 196\end{array}$ 
Comissão Julgadora

Marcos Tarcisio Masetto - Faculdade de Educação - USP

Elsa Garrido - Faculdade de Educação - USP

Maria Ligia C. Carvalhal - Inst. de Ciências Biomédicas USP

Cleide M. Nébias - UNESP - Campus Marília

Myrtes Alonso - PUC -SP 
Ao João Carlos, companheiro constante nos planos e realizações 
Aos nossos filhos: André, Gustavo e Daniel.

\section{AGRADECIMENTOS}

Ao Prof. $\mathrm{D}^{\mathrm{r} .}$ Marcos Tarciso Masetto, meu orientador, pela competência e segurança.

À Prof ${ }^{\text {a. }} \mathrm{D}^{\text {ra. }}$ Myriam Krasilchik pela aceitação desde o primeiro momento.

À Prof ${ }^{\text {a. }} \mathrm{D}^{\text {ra. }}$ Maria da Graça N. Mizukami pelas sugestões e críticas.

À Prof ${ }^{\text {a. }} \mathrm{D}^{\text {ra. }}$ Myrtes Alonso pelas contribuições e pela forma como foram feitas.

À Prof ${ }^{\text {a. }} D^{\text {ra. }}$ Cleide M. Nébias pela competência, dedicação e amizade.

À Prof ${ }^{\text {a. }} D^{\text {ra. }}$ Miriam C. P. Porto Foresti, minha amiga e incentivadora.

À amiga-irmã Vera Lúcia B. Méo pela leitura e correção.

À $\mathrm{D}^{\text {ra. }}$ Denise A. Teixeira pela amizade e firmeza.

Aos professores, sujeitos da pesquisa, sem os quais não teria sido possível realizá-la.

Aos meus amigos do N.K.P.A.F.

Aos meus queridos João Carlos, André, Gustavo, Daniel, Liliane, Tereza e Tula, pela paciência, estímulo e carinho.

Nos momentos em que o cansaço, o desânimo e a sensação de não conseguir foram mais fortes, sempre tive mão segura, ombro amigo e uma palavra-luz:

é o companheiro da vida em comum, que compartilha, sustenta e confia;

são os filhos com a sabedoria e sensibilidade que os corações jovens já demonstram;

são as futuras noras que acompanham e encorajam;

são os familiares que apoiam e "torcem";

são os amigos, que além de "coisas prá se guardar", são pessoas para se lembrar e agradecer;

É, sobretudo, Deus. 


\section{RESUMO}

O presente trabalho caracteriza-se como um Estudo de Caso, com o objetivo de compreender a prática docente de professorespesquisadores do Instituto de Física de São Carlos, da Universidade de São Paulo. Foi utilizada a abordagem qualitativa de pesquisa educacional. Foram observadas as aulas ministradas no segundo semestre de 1994, de quatro professores, em disciplinas do Bacharelado e da Licenciatura, bem como realizadas duas entrevistas estruturadas com cada um deles. $\mathrm{O}$ elemento norteador na seleção dos professores foi a preocupação demonstrada também com o ensino, num ambiente profissional caracterizado pela projeção nacional e internacional na pesquisa em Física Teórica e Experimental. A análise dos dados foi realizada a partir de nove categorias criadas para essa finalidade e que englobam os principais aspectos da dinâmica de sala de aula. São as seguintes categorias: Planejamento, Execução, Docência, Interação, Avaliação, Binômio Ensino/Pesquisa, Características dos Professores, Experiências Anteriores e Dimensão Pessoal/Profissional. Nas conclusões buscou-se oferecer subsídios para futuros encaminhamentos quanto à formação continuada de professores de Física e de áreas correlatas, no ensino superior. Enfatizou-se a prática reflexiva por meio da tomada de consciência, direcionada ao processo de ensino e de aprendizagem.

Palavras-chave:

Formação pedagógica do professor universitário

Prática reflexiva

Saberes docentes 


\begin{abstract}
The present work aims to understand the teaching practice at graduate level used by Physics teacher-researchers. It is a Case Study on four teachers who carry out activities in teacher education and in bachelorship at the Physics Institute of São Carlos - USP. The choice of teachers was based in the evidence that their actuation also denotes preoccupation with the teaching practice in a professional environment which is characterised by the national and international projections in research on Theoretical and Experimental Physics. The qualitative approach in educational research was used. Two interviews were done with each one of the four teachers and observation of their lessons throughout the second semester of 1994 was carried out. The data analysis was carried out from nine categories that were created for this purpose and which embody the main aspects found in the classroom. The conclusions aim to offer subsidies for future applications concerning the continued education of Physics teachers and teachers from proximal fields. The reflective practice and awareness directed to the learning and teaching processes are emphasised.
\end{abstract}

Key words:

Higher education pedagogy

Reflexive practice

Knowledge of professors 


\section{INTRODUÇÃO}

A realização deste trabalho deu-se paralelamente ao início da construção de minha própria prática docente universitária, com os consequentes questionamentos sobre a atuação no ensino superior.

Ao assumir o magistério superior, em 1990, no Instituto de Física de São Carlos, e ao iniciar o doutorado, em 1991, na Faculdade de Educação da USP, passei a desempenhar os papéis de docente ao lado dos colegas professores e dos alunos do curso de Licenciatura e de pesquisadora na pós-graduação em Educação.

Vivenciando essas situações, minhas preocupações centralizaram-se, inicialmente, na estruturação do desempenho como professora, nas dificuldades que sentia e nas dúvidas relativas à prática de sala de aula de alunos adultos.

O distanciamento temporal, do meu próprio curso de formação, tornava as imagens tênues. Eram as vivências do exercício profissional no $1^{-}$grau e as do mestrado as mais próximas e mais presentes.

Como estruturar a atuação de professora-formadora de adultos de um curso profissionalizante? Como conduzir minha prática? Como os professores universitários realizam seu trabalho docente? 
A tais questionamentos vinham juntar-se outros, que denominei de técnicos, tais como: Que programação desenvolver? Que bibliografia utilizar? Que técnicas e recursos seriam mais adequados?

Num primeiro momento, a recorrência a alguns professores mais experientes permitiu os passos iniciais. A busca nos programas desenvolvidos em outras universidades e na literatura, assim como a participação em eventos científicos foram proporcionando, com a prática, delineamento mais nítido e seguro.

Os caminhos, portanto, vão sendo buscados, pesquisados, construídos, praticados e reconstruídos sucessivamente.

Os caminhos da aluna/professora/pesquisadora estavam por ser descobertos. As preocupações, então, centralizaram-se no modo como os professores pesquisadores do ensino superior estruturam sua prática docente. E como esta mesma prática é estruturada especialmente numa instituição e numa área do conhecimento - a Física - onde a primazia parece pertencer à pesquisa?

No interesse pela investigação da prática pedagógica do docente de $3^{\circ}$ grau, seja ele formador de professores e/ou de pesquisadores, existem dificuldades por não ser a docência encarada como a questão primeira. Concordo com Nóvoa quando afirma que a formação dos professores enfrenta resistências de setores conservadores e de setores intelectuais, em que

" uns e outros têm do ensino a visão de uma actividade que se realiza com naturalidade, isto é, sem necessidade de qualquer formação específica, na sequência da detenção de um determinado corpo de conhecimentos científicos"1 (1992a, p.21).

Os problemas educacionais têm sido tratados por docentes do ensino superior, ao longo do tempo, como questões sujeitas mais ao jeito pessoal de cada profissional.

"Os cientistas ou pesquisadores, apesar do ambiente
científico, e de viverem ou, para e da pesquisa,
quando tratam de assuntos educacionais, em vez de
apresentarem resultados de pesquisas educacionais,
apresentam gratuitas opiniões pessoais, não raro

${ }^{1}$ Nas citações de autores portugueses foi respeitada a ortografia vigente em Portugal. 
passionalmente. Ou seja, não têm para com os temas educacionais a mesma atitude científica que manifestam em relação ao objeto cotidiano de suas atividades técnica ... Conscientes do "status" de suas ocupações, realizam uma suspeita operação de didata, planejador de currículo, planejador de recursos humanos e até inventor de revoluções educacionais” (Salgado, J.A., 1978, apud Masetto, 1982, p. 44).

Repetidas vezes exteriorizaram que para ensinar é só preciso jeito, "jogo de cintura" e um pouco de "didática" - nominação dada ao manejo de sala de aula - ao lado do "bom", "sólido", "consistente" conhecimento específico da matéria.

Raras referências foram feitas à necessidade do conhecimento pedagógico ou do como se realiza a aprendizagem pelo aluno adulto. A preocupação com o interlocutor que vai ler uma publicação é frequente, não se fazendo acompanhar, no entanto, da mesma intensidade quando se trata do interlocutor-aluno adulto que vai ser ensinado.

Na história educacional, as pesquisas sobre a sala de aula do aluno-criança, do adolescente e do professor têm sido intensificadas a partir dos anos 70, pelos diversos especialistas, que focalizaram fatores incidentes sobre a análise deste espaço e de seus autores.

O $3^{\circ}$ grau tem se constituído em foco de atenção a partir da década de 90 e, ainda hoje, é generalizada a preocupação com a sala de aula dos pequenos.

A questão da Prática Docente tem sido investigação constante em minha trajetória pessoal/profissional.

No ano de 1990 iniciei minhas atividades universitárias junto ao curso de Licenciatura em Física, Química e Matemática, como docente de Psicologia da Educação, do Instituto de Física e Química de São Carlos, da Universidade de São Paulo.

Tal fato deu-se após treze anos no magistério de $1^{\circ}$ grau, séries iniciais, e de dois anos como coordenadora pedagógica de projeto da Secretaria da Educação do Estado de São Paulo, que criou os Centros de Formação e Aperfeiçoamento do Magistério (CEFAM), integrando a equipe que implantou o referido projeto em São Carlos. 
A integração ao CEFAM surgiu do interesse em verificar o que ocorria nos dois extremos do processo - o de formação (cujo meu único balizador era o da própria formação) e o da atuação como professora, nas séries iniciais .

A experiência com o CEFAM durou pouco tempo, porque passei a integrar o quadro de docentes do recém-criado curso de Licenciatura, no Instituto acima citado.

A preocupação com a formação e atuação de professores permanecia. Aprenderia, mais tarde, que "o professor é a pessoa. E uma parte importante da pessoa é o professor" (Nias,1991, apud Nóvoa, 1992a, p.25).

No tripé ensino, pesquisa e extensão, o primeiro é relegado a plano secundário. A academia não prestigia adequadamente a dimensão pedagógica e os próprios docentes desenvolvem atitude de dedicação à pesquisa, adotando a postura de que uma sólida bagagem na área específica do conhecimento é garantia necessária e suficiente para a atuação docente.

O trabalho proposto, não se insere naquilo que se configuraria como Avaliação ou como Intervenção. Trata-se de um estudo para compreensão da prática pedagógica que docentes-pesquisadores de Física - cuja atuação é denotativa da preocupação também com o ensino realizam nas suas salas de aula de Bacharelado e de Licenciatura, neste momento determinado de realização da pesquisa.

Entende-se tal estudo como de importância em termos pedagógicos e educacionais, já que alguns professores e muitos alunos universitários manifestam a necessidade de que a competência pedagógica seja alcançada e/ou aprimorada.

Masetto aponta ser este "momento crucial e adequado para se estudar, pesquisar, analisar e ousar propor pistas ou encaminhamentos visando aperfeiçoar as condições de aprendizagem em sala de aula de $3^{\underline{o}}$ grau” (1991, p. 11).

A análise da prática pedagógica de professorespesquisadores supõe, por um lado, conhecer o que a pessoa concebe sobre o que faz, o sentido que ela atribui à sua atuação como docente e o como entende a execução do seu ensino, embora tenha tido uma formação muito 
mais voltada para a pesquisa. Por outro lado, supõe também, conhecer aquilo que ela realmente faz e como é a sua atuação.

A proposta é a de compreender como se configura a atuação desse profissional que não teve formação/destinação, explicitamente, para a docência, já que se formou para ser pesquisador, mas que, na sala de aula, tem uma prática denotativa da preocupação com o ensino, além daquela evidenciada na pesquisa e/ou extensão.

Em outras palavras, trata-se de compreender a prática docente de professores que não tiveram formação pedagógica, e encontrar as bases em que eles elaboraram/organizaram o seu conhecimento pedagógico.

Uma alternativa que responderia de pronto é a de que sendo docente do Bacharelado, o professor-pesquisador teria, por este fato, um repertório mais ou menos comum com seus alunos, já que a destinação deles é relativamente semelhante à sua. Seus alunos serão professores universitários mais voltados para a pesquisa ou desenvolverão pesquisas em grandes empresas. Embora essa condição seja verdadeira, ela não é suficiente para explicar uma atuação bem sucedida pois, se o fosse, todos os docentes pesquisadores seriam igualmente bem sucedidos nas atividades de ensino.

Além disso, o professor-pesquisador que ensina na Licenciatura tem, por alunos, futuros professores cujo repertório de interesse e destinação é diferente do seu. Passa, então, a ter preocupação com aquele que vai atuar nas escolas de $2^{\underline{o}}$ grau e que, supostamente, não seria sua clientela, não tendo sido, portanto, formado para capacitá-la.

Assim, considero importante conhecer este processo sob a ótica do professor de Física e sob a minha ótica de profissional não pertencente a esta área específica - a Física.

Por meio do estudo da prática docente do professor de Física no $3^{\underline{0}}$ grau, objetiva-se refletir sobre ela e, se possível, tentar iluminar a compreensão e tecer encaminhamentos sobre o ensino no Bacharelado e na Licenciatura e a consequente formação de futuros pesquisadores e futuros professores.

Parto do pressuposto de que os professores de Física, no $3^{\underline{0}}$ grau, nem sempre são formados para atuarem como professores e se 
formam pedagogicamente na própria atuação docente, ou seja "aprendem fazendo", inicialmente por imitação ou bom-senso e, posteriormente, pela incorporação de experiências bem sucedidas possíveis de acontecer no processo de sua formação continuada.

Suponho que exercitem algum tipo de reflexão, embora não sistemática e nem sempre tenham a tomada de consciência de que a condução de seu ensino é produto de ações mais, ou menos, reflexivas.

Entende-se relevante para o Instituto de Física de São Carlos (IFSC/USP), a contribuição decorrente deste estudo sobre o professor cuja atuação é denotativa da preocupação que ele tem também com o ensino, embora o seu curso de formação possa não ter priorizado e não ter sido direcionado para a atuação docente.

Além disso, o IFSC tem tradição e reconhecimento nacional e internacional em pesquisa básica e aplicada, mas nenhuma tradição na pesquisa em ensino. Espera-se que este trabalho possa constituir-se num ponto inicial para reflexões sobre ensino no âmbito desta Unidade.

É preciso enfatizar que em todas as carreiras que formam professores, pesquisadores e tecnólogos, existem pessoas interessadas na reflexão sobre seu papel e desempenho de sua função docente.

Esta é uma característica que tem se tornado mais evidente nos eventos educacionais, no afluxo às disciplinas de Metodologia do Ensino Superior por alunos de pós-graduação das Ciências Biológicas e Exatas que vislumbram oportunidade de preencher lacuna pedagógica deixada pelos seus cursos de graduação e, finalmente, pelas iniciativas institucionais para o aperfeiçoamento, no ensino, por alunos pósgraduandos, através de programas de incentivo à docência.

Em termos da formação dos docentes de segundo grau e de professores-pesquisadores que poderão vir a ser docentes no terceiro grau, espera-se que profissionais envolvidos e instituições formadoras passem a desenvolver e incentivar a atitude da postura reflexiva a ser adquirida e exercitada, a fim de redimensionar as bases da construção da prática pedagógica no ensino superior.

Há necessidade de que seja uma reflexão quanto ao papel da Licenciatura, pois muitas vezes nos defrontamos com concepções, principalmente nos institutos de pesquisa e ensino, de que o trabalho na 
Licenciatura é uma questão menor, frente ao trabalho no Bacharelado, tido como uma questão maior e a visão, dos próprios docentes, de que é um curso mais fácil, fato que, entre outros motivos político-sociais, colabora para o seu desprestígio quando comparada ao Bacharelado.

Algumas vezes, tem-se não apenas concepções, mas exemplos concretos. É o caso da Licenciatura diurna em Física no IFSC. Tendo sido criada em 1988, deixou de existir como opção para aqueles que ingressaram no Bacharelado em Física, excetuando-se os ingressantes até 1992.

As justificativas alegadas foram as de que não havia número razoável de alunos optantes pelo curso. Mesmo existindo alunos matriculados e cursando as disciplinas da Licenciatura, oficialmente não havia optantes, pois eles só poderiam optar depois de integralizado um determinado número de créditos no Bacharelado.

O problema mais grave para a baixa demanda - que não foi mais baixa do que a demanda pelo Bacharelado nos seus anos iniciais, quando da sua criação em 1970²- foi a ausência de divulgação do curso.

No caso da Licenciatura noturna, criada em 1993, não podem ser feitas alegações quanto ao baixo número de alunos, já que este é significativo com relação ao total de matrículas no Instituto. São 120 alunos da Licenciatura noturna, com quatro anos de existência, para 165 do Bacharelado.

Quanto ao número de professores que se envolvem com a Licenciatura, seria desejável que fosse maior, tendo em vista concessão de vagas para contratação, pela Reitoria da USP, em decorrência da criação do curso. Os professores são contratados devido às linhas de pesquisa que desenvolvem e à certeza de que somarão esforços com os docentes existentes, no sentido da projeção científica do IFSC e não no sentido da contratação de profissionais interessados pela Licenciatura ou pelo Ensino de Física ou, ainda, com mestrado/doutorado em Educação. Dessa forma, o contratado é imediatamente incorporado às atividades de pesquisa, orientação, publicações e participação em eventos nacionais e internacionais, ministrando, também, aulas na Licenciatura.

\footnotetext{
${ }^{2}$ A partir de 1973 - ano em que a primeira turma de ingressantes no Bacharelado concluiria o curso - até 1979, a média anual de alunos formados foi de seis. Os números em cada ano foram: 1973 3; 1974 - 8; 1975 - 4; 1976 - 9; 1977 - 10; 1978 - 4; 1979 - 4. (Seção de Atividades Escolares do IFQSC).
} 
Merecem destaque positivo, no entanto, alguns pontos defendidos e que constituem o corpo do curso, tais como: a dotação de uma infraestrutura adequada, principalmente em laboratórios, para aqueles que serão professores no $2^{\underline{0}}$ grau e cuja formação desejável não pode ficar restrita ao livresco e repetitivo, bem como o contato dos alunos com disciplinas pedagógicas desde o início até o final do curso.

Sem dúvida, uma boa infraestrutura, pode proporcionar condição privilegiada de ensino e aprendizagem, além da possibilidade de aquisição, pelos futuros professores, da segurança desejável para um exercício docente diferenciado em que, por exemplo, seus alunos sejam levados às praticas em laboratórios, não permanecendo tão somente em sala de aula tendo apenas o livro didático como recurso.

O que se pode questionar é até que ponto esses aspectos não estariam sendo privilegiados para beneficiar o aprendizado de conteúdo técnico-científico, colocando a formação pedagógica em segundo plano.

Outro ponto a ser considerado, e agora com relação às disciplinas pedagógicas, é que, tendo início já a partir do primeiro ano do curso, seu enfoque fundamental deve ser a questão da formação para atuar na prática docente e não o contrário, ou seja, não apenas apoiar o trabalho técnico-científico secundando a formação pedagógica.

Finalmente, é um avanço ter as disciplinas pedagógicas ao longo de todo o curso. É preciso, no entanto, cuidar da concepção de professor que subjaz à proposta de formação, seja do futuro professor do $2^{0}$ grau, seja do futuro pesquisador que poderá vir a ser professor no $3^{\underline{0}}$ grau. Esta responsabilidade precisa ser compartilhada pelas disciplinas na sua totalidade. Vale garantir que elas sejam integradas entre si e com as demais disciplinas do curso.

A falta de formação pedagógica pode constituir-se em fator dificultador do bom desempenho docente. Nas palavras de Cunha, "para o $3^{\underline{0}}$ grau não há exigências legais que reconheçam a obrigatoriedade da formação pedagógica. Porém, também não há negação expressa de que esse conhecimento não seja útil $e$ necessário" (1994, p.45).

Há processos bem sucedidos de elaboração e organização do conhecimento em benefício do ensino, e mais do que isso, de resultados 
desejáveis em termos de procedimentos didáticos, relação professor-aluno e envolvimento com a disciplina em questão e com o grupo de alunos. O que viabilizou essa condição? Como essa prática destacada se realiza? Que fatores se conjugam e são determinantes? São pontos para reflexão.

No capítulo que se segue a esse, ao descrever o campus da USP em São Carlos e, especialmente, o Instituto onde se realizou o trabalho, mostro a tendência científico-tecnológica, desde o seu início, em 1953.

No ensino, ao curso de Engenharia, criado inicialmente, outros foram acrescentados, ao longo dos anos, estando o presente estudo concentrado no Bacharelado e na Licenciatura, que são descritos com maiores detalhes.

O objetivo do capítulo é o de situar onde foi realizado o trabalho e traçar as características principais desse espaço institucional.

No capítulo 3 é feita a revisão de pesquisas e trabalhos que têm enfocado a prática docente no ensino superior, como também são apresentadas as reflexões teóricas atuais no campo da prática e da formação de professores.

No capítulo 4 são descritos os aspectos metodológicos que nortearam a pesquisa realizada.

A análise dos dados é feita no capítulo 5, que apresenta as situações observadas em sala de aula e as entrevistas realizadas, retratando a prática e as opiniões dos professores quanto aos procedimentos didáticos, relação professor-aluno e dinâmica da sala de aula.

Finalmente, o capítulo 6 apresenta as principais conclusões e propõe encaminhamentos em termos de prática, experiência, reflexão e tomada de consciência, como eixos norteadores profícuos da atuação docente no ensino superior.

"O conflito entre a ação pedagógica e a reflexão dessa ação é a semente de uma nova ação".

M. L. R. Lima 


\section{RECUPERANDO UM POUCO DA HISTÓRIA}

Um breve histórico sobre a criação do Instituto de Física e das demais Unidades do campus da USP, em São Carlos, é apropriado na medida em que permite situar o contexto onde atuam os docentespesquisadores, objeto do presente trabalho.

Nóvoa destaca a importância da dimensão organizacional na formação do professor e define que

"o território de formação é habitado por actores individuais e colectivos, constituindo uma construção humana e social, na qual os diferentes intervenientes possuem margens de autonomia na condução dos seus projectos próprios. (...) É preciso não esquecer nunca que a formação é indissociável dos projetos profissionais e organizacionais" (1992a, p.30-31).

\section{1 - O CAMPUS DA USP EM SÃO CARLOS}

Como será descrito a seguir, o campus da USP em São Carlos, apresenta um caráter essencialmente científico-tecnológico, não obstante figurar entre seus cursos o de Arquitetura e as Licenciaturas. Tendo origem na Escola de Engenharia de São Carlos (EESC), com o desmembramento de alguns de seus Departamentos para dar origem a outras Unidades, que por sua vez desenvolvem cursos de graduação e de pós-graduação, os enfoques predominantes sempre foram a formação de quadros tecnológicos e a pesquisa nas áreas das ciências ditas exatas (Física, Química e Matemática). 
Desde que foi fundada, a USP criou diversos institutos visando ampliar sua atuação acadêmica, artística, científica e tecnológica. Hoje, conta com 35 unidades de ensino e pesquisa e 5 institutos especializados, distribuídos pelas cidades de São Paulo, Bauru, Piracicaba, Pirassununga, Ribeirão Preto e São Carlos.

A USP em São Carlos foi criada no período compreendido entre 1945 a 1964, período este de expansão do ensino superior no Brasil. A industrialização e a urbanização - decorrentes da alocação de recursos econômicos originários da agricultura - que se estendiam pelo interior do Estado, após terem se concentrado em sua capital, criavam necessidades de mão-de-obra técnica especializada para atender aos interesses das indústrias nascentes e da burocracia estatal. Foi nessa fase que surgiram manifestações de estudantes, políticos e empresários, reivindicando instalação de universidades e/ou faculdades em suas respectivas cidades.

Em São Carlos, as primeiras manifestações aconteceram em 1947, inicialmente na Escola Normal de formação de professores e centro da cultura local, onde os estudantes reivindicavam a criação de uma universidade para São Carlos, pleiteando uma Faculdade de Filosofia para cujas instalações eram sugeridas as próprias dependências daquela Escola.

Imediatamente a imprensa e os políticos locais passaram a defender a proposta. Foi apresentado projeto de lei propondo a criação de uma universidade em São Carlos. Consultada pelo Governador do Estado, a USP manifestou-se contra e sugeriu que, no interior, fossem criadas faculdades isoladas subordinadas àquela Universidade.

Assim, no início de 1948, o Projeto de Lei foi alterado propondo a criação da Faculdade de Engenharia de São Carlos, subordinada à USP. Aprovado pela Assembleia Legislativa e vetado pelo então Governador, o Projeto foi sancionado pelos deputados em agosto de $1948^{3}$. A instalação propriamente dita só ganhou novos impulsos em 1950, sob o governo de Lucas Nogueira Garcez. Em 1951 uma comissão da USP manifestou-se favoravelmente à instalação da Escola de Engenharia de São Carlos e sugeriu a criação do curso de Engenharia Civil. O projeto

\footnotetext{
${ }^{3}$ O Projeto de Lei aprovado transformou-se na Lei $n^{-0} 161$, de 26/08/48, cuja redação previa o seguinte: "Art. 1 ${ }^{0}$ - Ficam criadas, no interior do Estado e subordinados à Universidade de São Paulo, os seguintes estabelecimentos de Ensino Superior: I - Escola de Engenharia, em São Carlos; II - Faculdade de Farmácia e Odontologia, em Bauru e Taubaté; III - Faculdade de Medicina, em Ribeirão Preto; IV - Faculdade de Direito, em Campinas; V - Faculdade de Filosofia, Ciências e Letras, em Limeira". Deve-se ressaltar que só foram efetivamente instaladas, pela USP, as unidades de São Carlos e Ribeirão Preto e, mais tarde, a Faculdade de Odontologia em Bauru.
} 
acadêmico foi produzido na USP e em agosto de 1952 o Conselho Universitário aprovou a instalação do novo estabelecimento, elaborou o anteprojeto compondo a estrutura didática e criou cargos docentes, técnicos e administrativos.

Em 1952, uma Comissão Executiva da USP propôs que a Escola de Engenharia de São Carlos (EESC) fosse criada buscando formação mais generalista, em dois cursos: de Engenharia Civil e de Engenharia Mecânica. Em 1953, a EESC realizou seu primeiro vestibular com 50 vagas para ambos os cursos. Esta foi a primeira Unidade em São Carlos.

Em 1956, a administração e parte dos cursos foram transferidas para o que é hoje o Edifício Central da EESC. Gradativamente, novos prédios foram sendo construídos e novos laboratórios instalados.

A aprovação da Lei de Diretrizes e Bases da Educação de 1961, desencadeou, aliada à situação econômico-social, uma série de reivindicações na estrutura das universidades. Com a instauração do regime militar a partir de 1964, tais reivindicações ficaram amortecidas, sendo, entretanto, deflagradas a partir de 1966. Neste ano, ao seu final, foi instalada uma comissão especial para levantar propostas de restruturação da Universidade de São Paulo. A primeira proposta viria ao conhecimento do público em meados do ano seguinte, propondo, entre outros assuntos, a transformação da USP em fundação de direito público. As manifestações das diversas unidades universitárias, apoiando alguns pontos e rejeitando outros, colocou aquelas propostas numa situação de hibernação (Witter, 1984, p.121).

Paralelamente, o regime militar estabelecia um convênio com a USAID, através do MEC (Ministério da Educação e Cultura), passando a contar com a colaboração de assessoria de técnicos estrangeiros no seu projeto de reestruturação do sistema universitário brasileiro. $\mathrm{O}$ paradigma que norteou o projeto de reforma universitária promovido pelo Estado estava assentado nos princípios da racionalidade, eficiência e produtividade (Grígoli, 1990). Essa posição fica clara nas palavras de um dos membros do Grupo de Trabalho da Reforma Universitária para o qual

"seu objetivo primário é racionalizar a organização das atividades universitárias, conferindo-lhes maior eficiência e produtividade" e que "é necessário desideologizar a questão da universidade quando tratarmos de sua eficiência e produtividade no 
terreno da ciência e da tecnologia” (Sucupira, apud São José, 1990, p.118).

Assim, a reformulação estrutural da universidade brasileira, encomendada pelo MEC, em 1965, ao consultor americano Rudolph Atcon, teve como norteador o paradigma norte-americano de racionalidade organizacional, baseado no modelo empresarial de rendimento e eficiência. Segundo Fávero (1991, p.25), o funcionamento desse modelo separava os que "pensam" e os que "fazem" a universidade, criando o organograma de administração superior, centros e departamentos, "sendo estes a menor fração da estrutura universitária" 4

Fávero aponta, também, que no bojo da reforma universitária de 1968 estão presentes os interesses de modificar e disciplinar a universidade, tornando-a de modelo cultural das elites para local de formação de mão-de-obra.

Em 13/06/68, por ocasião de uma palestra de Atcon na USP, foi deflagrado o movimento de reforma universitária, a partir de suas forças internas, com a manifestação estudantil que invadiu a Reitoria da Universidade, manifestou-se contra a presença do assessor do MEC no campus e exigiu o posicionamento do Reitor em exercício sobre suas reivindicações (Witter, 1984, p. 127).

Algumas unidades da Universidade foram ocupadas pelos estudantes e em outras foram instaladas comissões paritárias de professores, alunos e funcionários. Na então Faculdade de Filosofia, Ciências e Letras, em meados do segundo semestre daquele ano, as comissões paritárias chegaram a ser homologadas pela Congregação.

Em São Carlos, a movimentação estudantil levou à instalação do assim chamado Fórum Universitário que se reuniu diariamente nos meses de julho e agosto de 1968, com participação significativa dos estudantes, professores e funcionários, para discutir a Universidade, seus cursos, sua estrutura administrativa e propor medidas, tanto locais como no âmbito mais amplo da USP. Constavam das reivindicações locais, por exemplo, a criação, já para o ano seguinte, dos novos cursos de Matemática, Física, Arquitetura e Planejamento e Engenharia Elétrica. Outras das sugestões aprovadas no Fórum referiam-se à criação dos campi no interior, à extinção das cátedras, à criação de novos

${ }^{4}$ Estatuto da USP. Artigo 51. 
institutos em São Carlos e à criação de fundos específicos no orçamento do Estado para o ensino e pesquisa ${ }^{5}$.

A movimentação de docentes e estudantes, principalmente nas unidades da USP da capital, levou o Conselho Universitário a acelerar a tramitação das reformas. Em setembro daquele ano, numa semana, após aprovação pelo Conselho Universitário e pelo Conselho Estadual de Educação, o Governador do Estado assinava o Decreto que alterava os Estatutos da Universidade possibilitando que as alterações estatutárias fossem efetuadas com maioria simples dos votos do Conselho. Ainda no mesmo mês, eram publicadas nos jornais as resoluções adotadas: extinção das cátedras, a adoção do sistema departamental na estrutura da Universidade e a criação dos campi. Algumas dessas medidas entraram logo em vigor, enquanto outras foram postergadas. As reivindicações mais abrangentes de reestruturação da Universidade foram abandonadas e a reforma acabou sendo feita de cima para baixo (Witter, 1984, p.129-145).

Em dezembro daquele ano, com a promulgação do AI-5 e a imediata aposentadoria compulsória de vários docentes, a movimentação acadêmica arrefeceu. Foram, entretanto, efetivadas algumas das medidas que faziam parte das reivindicações da comunidade acadêmica. Foram criados os Departamentos e extintas as cátedras e, pouco mais de dois anos após, os campi foram instalados, alterando-se, entretanto, a estrutura de liberdade acadêmica inicialmente sugerida.

Em decorrência, o ano de 1970, em São Carlos, foi marcado pelos novos cursos de Engenharia Elétrica, de Engenharia de Produção, do Bacharelado em Matemática e do Bacharelado em Física e a realocação dos docentes da Escola de Engenharia em doze Departamentos ${ }^{6}$.

Em 1971, quatro Departamentos da EESC passaram a integrar duas novas Unidades: os de Matemática e de Ciências de Computação e Estatística formaram o Instituto de Ciências Matemáticas de São Carlos (ICMSC), enquanto os de Física e Ciências dos Materiais e de Química e Física Molecular, constituíram o Instituto de Física e Química de São Carlos (IFQSC). Desse modo ficaram atendidas algumas das reivindicações do Fórum Universitário, que mais interessavam aos docentes

${ }^{5}$ CENTRO ACADÊMICO ARMANDO DE SALLES OLIVEIRA. Fórum universitário: EESC, 1968. Proposta Aprovada. São Carlos : CAASO, 1973. (Texto, 7).

${ }^{6}$ Foram criados os Departamentos de: Física e Ciência dos Materiais, Química e Física Molecular, Matemática, Ciências da Computação e Estatística, Arquitetura e Planejamento, Estruturas, Hidráulica e Saneamento, Geologia, Vias de Comunicação e Transportes, Materiais, Mecânica e Engenharia Elétrica. 
dos departamentos envolvidos, já que lhes davam uma parcela adicional de poder na estrutura universitária, com a relativa autonomia que passavam a ter com o desmembramento da Escola de Engenharia.

No ano seguinte, 1972, foi criado oficialmente o campus de São Carlos, abrangendo a EESC, o ICMSC e o IFQSC.

Os novos Institutos, além da manutenção de cursos de graduação $^{7}$ e pós-graduação, agregaram às suas administrações as disciplinas básicas dos cursos de Engenharia, isto é, as da área da Matemática no ICMSC e as das áreas de Física e Química no IFQSC. O novo campus, ao contrário do que sua comunidade universitária reivindicara em 1968 - um campus nas áreas de artes, ciências e tecnologia - mantinha desde suas origens a conotação científico-tecnológica. Uma pequena alteração só viria na segunda metade da década seguinte com a implantação do curso de Arquitetura, no âmbito da EESC (1985), dos cursos de Licenciatura em Física e em Matemática (1988) e da Licenciatura em Química (1989).

O ICMSC constitui-se, ainda hoje, dos dois departamentos iniciais. A EESC tem suas atividades distribuídas pelos oito departamentos remanescentes do desdobramento das duas novas unidades.

Em abril de 1994, o IFQSC foi desdobrado em duas novas Unidades: o Instituto de Física de São Carlos (IFSC) e o Instituto de Química de São Carlos (IQSC). Na época, o IQSC já contava com dois Departamentos resultantes da divisão do Departamento de Química e Física Molecular. Junto com o desmembramento do IFQSC, o Departamento de Física e Ciência dos Materiais foi dividido, dando origem ao novo Departamento de Física e Informática, ambos formando o atual IFSC.

\section{2 - O INSTITUTO DE FÍSICA DE SÃO CARLOS}

Após esse resumo histórico das várias unidades de ensino e pesquisa que compõem o campus da USP em São Carlos, será descrito, com detalhes adicionais, o Instituto onde foi realizado o presente trabalho.

\footnotetext{
${ }^{7} \mathrm{Na}$ época já estavam instalados os cursos de Bacharelado em Matemática, Física e Química.
} 
Desde seu início e até hoje, o Instituto de Física de São Carlos mantém algumas características que o destacam entre as demais unidades da USP, tais como: pouca rotatividade dos professores ${ }^{8}$; contratação dos docentes em regime de dedicação integral ${ }^{9}$; padrão de pesquisa de excelência nacional e internacional; atualização constante do corpo docente no exterior; prática extensa de publicação de artigos em periódicos de circulação internacional; financiamentos de agências governamentais etc. ${ }^{10}$

O IFQSC - agora IFSC - sempre se destacou por inúmeras razões, entre elas a pesquisa básica e aplicada como o centro de todas as suas atividades. Antes da existência do Instituto, já em 1956, quando o quadro de docentes era composto apenas por aqueles envolvidos com as disciplinas básicas da Engenharia, as atividades de pesquisa tiveram início por este pequeno grupo de pesquisadores que recebeu grande impulso, em consequência do apoio da Fulbright Commission, que permitiu a vinda de professores visitantes de universidades americanas para ministrar cursos e colaborar na implantação de várias linhas de pesquisa teórica e experimental e, ao mesmo tempo, propiciar a ida de vários membros do grupo aos Estados Unidos para estagiarem em renomados laboratórios de pesquisa. Esse programa é citado como sendo o primeiro, a longo prazo, da Fulbright Commission na América Latina ${ }^{11}$.

$\mathrm{Na}$ época, foram estruturadas as primeiras oficinas de apoio que permitiram a construção de equipamentos para a pesquisa e para o ensino. É desse período, a constituição de laboratórios de pesquisa com o apoio do Conselho Nacional de Desenvolvimento Científico e Tecnológico (CNPq) e o Banco Interamericano de Desenvolvimento (BID).

A colocação do IFSC como centro de pesquisa pode ser corroborada pelo seu destaque frente às demais unidades da USP no item publicações de artigos em revistas e periódicos especializados, nacionais e

\footnotetext{
${ }^{8}$ No quadro docente do DFCM (Departamento de Física e Ciência dos Materiais), de 1978, permaneciam 15 dos 18 docentes do quadro de 1972; em 1991 permaneciam 36 dos 44 do quadro de 1978; em 1995 eram 54 do quadro de 55 docentes de 1991. Em 1995 ocorreram aposentadorias e contratações e, atualmente, são 51 docentes ( dados do IFSC ).

${ }^{9}$ No Processo USP, de criação da EESC, já havia a previsão de que para as disciplinas básicas os docentes deveriam ser contratados "obrigatoriamente em regime de tempo integral” (p.121).

${ }^{10}$ Of. CPA no 026/93, que encaminha o relatório da Comissão de Avaliação do DFCM.

${ }^{11}$ Resumo Histórico das Principais Contribuições do Prof. Sérgio Mascarenhas. IFQSC, p.6, s.d.
} 
internacionais. Por exemplo, quanto à Produção Científica, o IFSC 12 ocupou o primeiro lugar entre as 35 Unidades da USP ${ }^{13}$.

Sendo o IFSC uma unidade universitária que ocupa uma posição de destaque no seio dos centros de pesquisa do país, abre-se um campo instigante para o estudo de como ali se processam as relações entre a pesquisa desenvolvida e o ensino ministrado. Por outro lado e mais diretamente relacionado aos objetivos do trabalho, é aquele Instituto um campo interessante de estudos de como se processa, neste ambiente marcado pela procura do conhecimento científico, a prática docente dos professores-pesquisadores que o compõem.

A capacitação para o desenvolvimento da pesquisa exigiu e continua exigindo a implantação e a expansão de uma sofisticada infraestrutura composta de oficinas, laboratórios de apoio, biblioteca, centro de computação, bem como a manutenção de quadro técnico de bom nível profissional. As oficinas de mecânica e de ótica, os laboratórios de eletrônica, de criogenia, de computação e de ensino e os setores de manutenção e da gráfica, formam uma eficiente infraestrutura de apoio ao ensino e à pesquisa.

A infraestrutura para o ensino está concentrada num prédio onde estão instalados os Laboratórios de Ensino de Física (LEF), composto de salas de aula e laboratórios de mecânica, termodinâmica, eletricidade, magnetismo, ótica, física moderna, eletrônica, biologia e microcomputadores, onde são ministrados cursos para alunos de Física, Química, Computação Matemática e Engenharias ${ }^{14}$ e estudados vários fenômenos físicos descobertos neste último século. São mostradas as técnicas modernas de estudo e caracterização dos materiais, através da Ressonância Magnética Nuclear e Eletrônica, Holografia etc.

A estrutura de apoio para estes laboratórios e salas de aula é facilitada por recursos didáticos adicionais, tais como: experimentos demonstrativos, vídeo, retroprojetores em todas as salas, telas de projeção, filmadora, máquina fotográfica, computador, projetor de tela de computador e por oficinas de eletrônica, mecânica e vidraria, onde são elaboradas e construídas experiências a serem utilizadas em aulas.

\footnotetext{
${ }^{12}$ Anuário Estatístico - USP/1995, p.133. Os dados são de 1994 e referem-se à média de trabalhos por docente. O Anuário traz informações da produção científica média por docente em cada Unidade, de 1987 até 1994, e o IFQSC ocupa sempre, pelo menos, a terceira posição.

${ }^{13} \mathrm{Em}$ maio de 1994, com a divisão do IFQSC, em IF e IQ/SC, a USP passou a contar com 35 Unidades.

${ }^{14}$ Todas as informações sobre o LEF foram extraídas de material impresso pelo LEF/IFSC/USP.
} 
Para a realização das atividades de ensino, o LEF conta com o apoio de técnicos experientes em Ensino de Física Experimental. O quadro de monitores do IFSC é composto por alunos da graduação, mestrado e doutorado em Física, além de estagiários de uma escola técnica de São Carlos. Eles também participam da elaboração das aulas e das práticas desenvolvidas.

Mais recentemente podem ser destacadas duas outras características do Instituto: uma delas é a larga experiência no relacionamento com o setor produtivo, inclusive gerando pólo de empresas de alta tecnologia da cidade ${ }^{15}$. A outra é a política de constituição de grupos de pesquisa com linhas bem definidas.

$\mathrm{O}$ estreito relacionamento com o setor produtivo de São Carlos e de todo o Brasil teve início em 1968 e intensificou-se a partir de 1980, através de convênios para a realização de pesquisas com vistas às aplicações tecnológicas. Foi decisiva a participação dos docentes do Departamento de Física e Ciência dos Materiais, na década de 1980 para a implantação e consolidação do Parque de Alta Tecnologia de São Carlos.

Em 1992, por Portaria do Reitor, e em cumprimento ao dispositivo dos Estatutos da Universidade de São Paulo, alguns Departamentos de Unidades da USP passaram por avaliação de suas atividades de pesquisa, ensino e prestação de serviços.

O Departamento de Física e Ciência dos Materiais (DFCM), que se dividiu para originar o atual IFSC, foi avaliado no $1^{-}$ciclo pela Comissão de Avaliação Departamental (CAD) e pela Comissão Permanente de Avaliação (CPA) ${ }^{16}$. De acordo com os objetivos da avaliação realizada, o DFCM foi considerado o melhor dos departamentos da USP avaliados naquela etapa.

A distribuição de docentes por nível de titulação, com $96 \%$ tendo o título de doutor ${ }^{17}$, foi considerada adequada aos fins do

\footnotetext{
${ }^{15}$ No final de 1984 foi criada a Fundação Parque de Alta Tecnologia de São Carlos, com a participação de docentes do IFQSC.

${ }^{16}$ Cópias do Of.CPA no ${ }^{0}$ 026/93, do Coordenador da CPA, anexando o relatório da Comissão de Avaliação do Departamento, enviado ao Diretor do IFQSC (cc. ao Chefe do DFCM) foram distribuidas aos docentes do Departamento.

${ }^{17} \mathrm{Em} 1995$ o IFSC contava com 54 docentes, dos quais 21 no FCM e 33 no FFI. Por categoria eram: 10 Titulares, 17 Associados, 25 Doutores e 2 Assistentes. Atualmente são 51 docentes: 20 do FCM e 31 do FFI. São 10 titulares, 16 associados, 23 doutores e 2 assistentes.
} 
Departamento. Destacou-se, também, a formação e participação de seus docentes em programas de doutorado e pós-doutorado no exterior, resultando num intercâmbio de influência significativa na capacitação de seus profissionais.

A Comissão analisou, ainda, a produção científica, a formação de recursos humanos pelos cursos de pós-graduação, os processos de contratações de docentes, os concursos da carreira docente e as avaliações para recontratação de professores, baseadas principalmente na produção científica, capacidade didática (entendida como a assunção de carga didática de graduação e pós) e orientação de estudantes.

A produção científica foi comparada, na Avaliação, à dos melhores departamentos de universidades do país. A obtenção de recursos de agências financiadoras pelos projetos que o departamento executou foi muito significativa ${ }^{18}$, envolvendo a maioria de seus pesquisadores e permitindo o desenvolvimento de novas linhas de pesquisa, aquisição de equipamentos de primeira geração e estímulo a jovens pesquisadores.

Outra característica que merece destaque é a de que, excetuando as disciplinas básicas oferecidas aos cursos de Engenharia, o DFCM dedicou-se, antes da criação de cursos de graduação, ao fortalecimento de seus grupos de pesquisadores e ao desenvolvimento de seus cursos de Mestrado e Doutorado ${ }^{19}$. A antecedência das atividades de pós-graduação às do curso de Bacharelado e de Licenciatura, mais que uma característica de originalidade perante outras unidades universitárias do país, indica, mais uma vez, a prioridade que a pesquisa tem ao longo do tempo da existência do grupo de Física em São Carlos.

No ensino de pós-graduação, continuam existindo as áreas de Física Básica e Física Aplicada, esta contando com a sub-área Física Computacional. Nas avaliações dos cursos de pós-graduação efetuadas pela CAPES, tem sido obtido o conceito A, tanto no Mestrado como no Doutorado.

Em outubro de 1992, foi criado o curso de pós-graduação interunidades IFQSC/EESC, agora IFSC/IQSC/EESC, de Ciência e Engenharia de Materiais, com funcionamento a partir de 1993.

\footnotetext{
${ }^{18}$ A Comissão de Avaliação cita a cifra de 8 milhões de dólares anuais obtidos em 1992 pelo Departamento junto às agências financiadoras de projetos de pesquisa.

${ }^{19}$ As atividades de pós-graduação foram estabelecidas já em 1961, graças ao apoio do programa Fulbright Fonte: Resumo Histórico das contribuições mais importantes do Prof. Sérgio Mascarenhas, IFQSC, s.d.
} 
Até 1992, o número de alunos matriculados nos cursos de pós-graduação, desde o reconhecimento das suas áreas de Mestrado e Doutorado, foi sistematicamente maior do que o número de alunos matriculados nos cursos de graduação. A relação tem se alterado com a criação das Licenciaturas ${ }^{20}$. Os dados de 1995 apontavam 175 alunos de pós-graduação - 110 do Mestrado e 65 do Doutorado - para 304 alunos de graduação - 184 do Bacharelado, 19 da Licenciatura diurna e 101 da Licenciatura noturna. Em 1996 são 171 de pós-graduação (mestrado: 71 e doutorado 100) para 294 de graduação (Bacharelado: 165; Licenciatura diurna: 9 e Licenciatura noturna: 120).

Percebe-se, portanto, que a relação de alunos de pósgraduação e de alunos do Bacharelado é equivalente. No decorrer da existência do IFSC, anteriormente à criação do curso noturno (de Licenciatura), ou esta relação se mantinha ou o número de alunos de pósgraduação era superior. A partir da implantação da Licenciatura noturna (1993), o número de estudantes de graduação passou a ser maior pelo fato de que, atualmente, apenas esse curso contribui com mais de $40 \%$ dos graduandos. Isso demonstra não só a existência de demanda social para cursos noturnos, como também para o curso de Licenciatura, que está tendo procura significativa.

A participação dos discentes (graduação e pós-graduação) nas atividades de pesquisa é garantida por bolsas de estudos CAPES21, FAPESP ${ }^{22}, \mathrm{CNPq}^{23}$, monitorias no CDCC (Centro de Divulgação Científica e Cultural), nas disciplinas experimentais, ou ainda através de projetos específicos de pesquisa. As bolsas de Iniciação Científica contemplam um número significativo de alunos da graduação ${ }^{24}$.

\footnotetext{
${ }^{20}$ Anuário Estatístico - USP/95, p.30-31. Nos anos de 1989, 90 e 91, para o IFQSC, os números de alunos de graduação foram, respectivamente, 335,319 e 380 , enquanto que os de pós-graduação foram 420, 441 e 408. Nos anos de 1992, 93 e 94, foram respectivamente, 407, 447 e 515 da graduação, para 371, 430 e 443 da pós-graduação. Os dados de 95 e 96 referem-se ao IFSC, lembrando que a separação ocorreu em 1994.

${ }^{21}$ Coordenação de Aperfeiçoamento de Pessoal de Nível Superior - órgão do Ministério da Educação.

${ }^{22}$ Fundação de Amparo à Pesquisa do Estado de São Paulo.

${ }^{23}$ Conselho Nacional de Desenvolvimento Científico e Tecnológico, do Ministério de Ciência e Tecnologia.

${ }^{24} \mathrm{Em}$ 1994, a relação entre o número de alunos matriculados nos cursos do IFSC e o número de bolsas de Iniciação Científica (FAPESP, CNPq, CAPES e outras instituições), foi de 3 alunos/ bolsa. Fonte: Anuário Estatístico - USP, 1995, p.19 e 96.
} 
O IFQSC mantinha, até maio de 1994, um órgão anexo, a Coordenadoria de Divulgação Científica e Cultural (CDCC) criada em 198125, no prédio da Casa de Itália (primeira instalação da EESC), responsável pela integração Universidade-Comunidade. Após a divisão do Instituto, essa Coordenadoria foi transformada em Centro de Divulgação Científica e Cultural, passando a contar com orçamento e pessoal próprio ${ }^{26}$.

Sua criação resultou de um Simpósio de Integração Universidade-Escolas de $1^{\underline{0}}$ e $2^{\underline{o}}$ graus, realizado em São Carlos, com a participação de 250 professores, e com "o objetivo de contribuir para romper, em nível regional, a barreira que tradicionalmente separa o ensino básico do universitário". Entre as sugestões finais constava a criação de um espaço para que se intensificasse o intercâmbio que havia tido início com a realização daquele evento ${ }^{27}$.

Considerado de Utilidade Pública ${ }^{28}$ as realizações do CDCC tiveram início em 1981 e se ampliaram, alteraram ou solidificaram no decorrer desses anos. São: cursos de férias para alunos de $1^{\underline{0}}$ e $2^{\underline{0}}$ graus, plantões de atendimento de monitores aos alunos da rede oficial de ensino, projeção semanal de filmes científicos e culturais, participação no Congresso de Jovens Cientistas, Excursões e Visitas, cursos de atualização científica, em diversas áreas, para professores de São Carlos e região. Possui, ainda, biblioteca especializada, laboratórios de ensino, oficinas, cineclube, experimentoteca, museu vivo de ciências, centro para divulgação da Astronomia (Observatório), Mulher de Vidro (modelo anatômico de tamanho natural) para o ensino de Ciências e Biologia. Anualmente realiza a Feira de Ciências, Letras e Artes de São Carlos - FECLAR - com trabalhos de escolas de $1^{\underline{o}}$ e $2^{\underline{\underline{o}}}$ graus de São Carlos e região ${ }^{29}$.

\footnotetext{
${ }^{25}$ A Coordenadoria de Divulgação Científica e Cultural foi criada pela diretoria do Instituto de Física e Química de São Carlos/USP, pela Resolução n⿳0 1988/80, e seu Regimento foi oficializado pela Portaria n⿳⺈ 172/81 (D.O do Estado de São Paulo de 27/01/81), dando continuidade a um trabalho iniciado em 1979, no I Simpósio de Integração Universidade-Escolas de $1^{\circ}$ e $2^{\underline{0}}$ graus.

${ }^{26}$ Em 17 de maio de 1994, juntamente com a Resolução no 4077 que extinguiu o IFQSC e criou os Institutos de Física e de Química de São Carlos, a CDCC foi transformada em Núcleo de Apoio às Atividades de Cultura e Extensão Universitária, chamando-se NACE-CDCC (Resolução nº 4078). Em 1995 tornou-se Centro de Divulgação Científica e Cultural.

27Integração universidade-escolas de $1^{\circ}$ e $2^{\underline{0}}$ graus. In: Encontro do SINEC,1, São Carlos, 1979. Anais. São Carlos: SINEC,1979.

${ }^{28}$ Lei Municipal no 9187/84 (D.O. do Estado de São Paulo de 05/10/84).

${ }^{29}$ Histórico de Desenvolvimento dos Trabalhos do CDCC. Relatório Interno.
} 
Além dos $1800 \mathrm{~m}^{2}$ no centro da cidade, possui também Observatório no campus da Universidade e uma área ecológica para o treinamento de professores em Ciências Ambientais

Um dos principais projetos do CDCC é a Experimentoteca Pública, um Laboratório de Ciências que se destina aos alunos de $5^{\mathrm{a}}$ a $8^{\mathrm{a}}$ séries do $1^{\underline{0}}$ grau. Há também equipamento específico para Física e Química do $2^{\underline{0}}$ grau.

"A Experimentoteca é formada basicamente por material experimental ou demonstrativo, além de filmes para vídeo, mapas, modelos e jogos. $O$ material experimental possibilita a experimentação por 10 equipes de alunos, trabalhando simultaneamente sobre cada tema, em sala de aula. $O$ programa Experimentoteca prevê a capacitação dos professores usuários do sistema em cursos específicos. A Experimentoteca é projetada de acordo com modernas técnicas de design, permitindo a reprodução em série". 30

As maletas de kits da Experimentoteca, à disposição das escolas de São Carlos e de dez cidades vizinhas, são entregues e recolhidas pelo próprio CDCC mediante requisição dos docentes.

O CDCC tem trabalhos culturais e científicos em andamento, nas áreas de: Astronomia, Física, Química, Biologia, Computação e Matemática, coordenados pelo seu diretor e por docentes do IFSC, IQSC e ICMSC, auxiliados por técnicos especializados de nível superior e alunos de graduação e pós-graduação das diversas unidades envolvidas que se ocupam do atendimento e orientação de usuários, professores da rede de ensino e alunos de $1^{\underline{0}}$ e $2^{\underline{\underline{o}}}$ graus.

Os principais projetos em desenvolvimento no CDCC são financiados pela Fundação VITAE, Ministério da Educação (MEC) e Secretaria de Ciência, Tecnologia e Desenvolvimento Econômico (SCTDE).

\footnotetext{
${ }^{30}$ Relatório encaminhado à USP por ocasião da transformação da Coordenadoria em Núcleo.
} 


\section{3 - BACHARELADO EM FÍSICA}

O curso de Bacharelado em Física no IFQSC (hoje IFSC), iniciado no ano de 1970, foi reconhecido pelo Decreto $\mathrm{n}^{\circ} 82591$ de 07/11/78 e tem por objetivo formar pesquisadores em Física. Seu currículo contempla disciplinas teóricas e de laboratórios básicos e avançados, no curso de quatro anos. Atualmente, existem 165 alunos. A partir do segundo ano letivo do curso, a maioria deles recebe bolsas de Iniciação Científica.

O Bacharelado desenvolveu-se tomando como modelo o curso da Faculdade Nacional de Filosofia. As mudanças na sua estrutura curricular têm ocorrido pela inclusão de novas disciplinas, numa tentativa de modernizá-lo. Cresceu também o número de interlocutores e os meios de aprendizado acessíveis aos alunos de graduação. A monitoria, a participação em congressos científicos, a existência de programas de seminários de grupos e colóquios de interesse geral, a interação com alunos de pós-graduação e com professores visitantes, são alguns exemplos da diversificação dos meios e da diversidade de interlocutores que têm contribuído para enriquecer a formação dos alunos de graduação.

Na Avaliação do Departamento, realizada pela Comissão Permanente de Avaliação da USP, em setembro de 1992, foi observado que "o currículo do curso de graduação parece ser baseado naqueles utilizados em outros países e, por vezes, se adapta às demandas diretas do mercado de trabalho, como é o caso da recente agregação da Física Computacional"31.

O relatório da Comissão destacou também que
"o chefe do Departamento e assessores
manifestaram, apropriadamente, frustração por não
existirem medidas objetivas para medir a eficiência
do ensino, o que os leva a efetuar avaliações
baseadas em impressões intuitivas." (p. 5).

Até o ano de 1992, os alunos da graduação realizavam o levantamento anual das suas opiniões, por meio de questionário elaborado e aplicado por eles mesmos e pelos Assessores Didáticos, a respeito dos

\footnotetext{
${ }^{31}$ Relatório da Comissão Permanente de Avaliação, p.6, setembro/92.
} 
professores e das disciplinas. Os resultados eram mostrados aos professores e afixados em quadro nas dependências do departamento.

Os alunos

"têm a oportunidade de ter contato, durante o curso, com uma infraestrutura de pesquisa básica e aplicada. Como por exemplo, o estudante poderá complementar seus estudos de graduação desenvolvendo pesquisas em laboratórios de crescimento de cristais, ótica, semicondutores, ressonância magnética, eletretos, biofísica e outros. Poderá desenvolver trabalhos na área de física teórica em semicondutores, metais, física atômica, mecânica estatística etc. Após os estudos de graduação, o bacharel poderá optar por continuar a carreira universitária, engajando-se nos cursos de Mestrado e Doutorado do IFSC. Poderá, ainda, se engajar em centros de alta tecnologia (um deles existente em São Carlos), laboratórios especializados, ou atuar como professor universitário"32.

\section{4 - A LICENCIATURA DIURNA EM FÍSICA}

As Licenciaturas diurnas foram implantadas, no Instituto, adotando-se o modelo proposto pelo Parecer $\mathrm{n}^{\mathrm{o}}$ 292/62, do Conselho Federal de Educação, cujo núcleo comum com o Bacharelado se estendia pelos quatro primeiros semestres, diversificando-se o currículo a partir do quinto período letivo.

É interessante situá-las no contexto dos demais cursos de formação de professores, até porque elas surgiram na época em que as sociedades científicas estavam participando ativamente das discussões com o governo central, buscando alternativas para a crise que se instalara a partir da imposição do modelo de Licenciatura curta.

\footnotetext{
${ }^{32}$ Catálogo dos Cursos de Graduação da USP - 1995.
} 
Braga (1988) ${ }^{33}$ comenta a legislação que caracterizou a política governamental referente à formação de professores para o ensino de $1^{\underline{0}}$ e $2^{\underline{o}}$ graus e referente às posições assumidas pela comunidade acadêmica e pelas sociedades científicas, no período 1972-1987. O autor enfatiza a "repulsa e indignação" que a Resolução $\mathrm{n}^{\mathrm{0}}$ 30/74 provocou na comunidade científica do país, expressas nas posições assumidas pela SBPC (Sociedade Brasileira para o Progresso das Ciências) e pela SBF (Sociedade Brasileira de Física). O modelo de Licenciatura preconizado pela Resolução do Conselho Federal de Educação estabelecera que a formação do professor em ciências e matemática, para as últimas séries do $1^{\underline{0}}$ grau, ocorreria exclusivamente num curso polivalente de curta duração. Às manifestações contrárias, da comunidade acadêmica, foram acrescidas as recusas de várias universidades à implantação de Licenciaturas nos moldes preconizados, o que levou o MEC a adiar a obrigatoriedade da implantação da Resolução 30/74 e a criar uma comissão para reexaminar a matéria. O autor constatou ter existido, ao longo daqueles anos de debate sobre as Licenciaturas, alguns consensos na comunidade acadêmica. O primeiro, e principal, foi o da rejeição à Licenciatura Curta. Como era frequente a participação de docentes-pesquisadores do Instituto de Física de São Carlos nas reuniões da SBPC e SBF, há grande possibilidade de que tenham, pelo menos, se inteirado daquelas posições.

$\mathrm{Na}$ USP não foram instaladas as Licenciaturas de curta duração. Seus cursos de formação de professores, até a incorporação da Faculdade de Filosofia de Ribeirão Preto e a instalação das Licenciaturas em São Carlos, sempre estiveram concentrados na capital, primeiramente na Faculdade de Filosofia, Ciências e Letras e após a Reforma Universitária, concentraram-se na nova Faculdade de Filosofia, Letras e Ciências Humanas, como também nos Institutos que foram criados com o desmembramento daquela Faculdade e, ainda, na Faculdade de Educação, que, então criada, passou a ser responsável pelas disciplinas pedagógicas.

A Faculdade de Filosofia foi criada em 1934 para ser o ponto central da Universidade de São Paulo e responder pelas disciplinas básicas dos cursos das escolas superiores que foram incorporadas ${ }^{34}$. Após dois anos de discussões no Conselho Universitário, ficou decidida a

\footnotetext{
${ }^{33}$ Braga, M.M. A licenciatura no Brasil: um breve histórico sobre o período 1973-1987. Ciência e Cultura, v.40, n.2, p. 151-157, fev. 1988.

34“No período da fundação da USP, a FFCL deveria integrar as demais escolas superiores existentes na época, num todo único. Estas escolas eram Faculdade de Direito, Medicina, Escola Superior de Agricultura Luiz de Queiroz e Escola Politécnica" (Witter, J.S. USP/50 anos: registro de um debate. São Paulo : Reitoria da Universidade de São Paulo, p.26, 1984).
} 
manutenção do sistema anterior e a Faculdade de Filosofia concentrou suas atividades na pesquisa e na formação de professores.

No Decreto-Lei no ${ }^{0}$ 1190/39, destinado à organização da Faculdade Nacional de Filosofia, foi criado o assim chamado modelo " $3+1$ " de formação de professores. Após o curso de Bacharelado com duração de três anos, os alunos podiam frequentar um curso de Didática, com duração de um ano, compreendendo as disciplinas de Didática Geral, Didática Especial, Psicologia Educacional, Administração Escolar, Fundamentos Biológicos da Educação e Fundamentos Sociológicos da Educação.

O decreto-lei n ${ }^{0}$ 9092/46 equiparou a duração dos cursos de Bacharelado e Licenciatura, sendo que no quarto ano os candidatos ao diploma de licenciado, além de algumas disciplinas em comum com os alunos do Bacharelado, recebiam também formação didática, sendo obrigatório o curso de Psicologia Aplicada à Educação.

Após a Lei de Diretrizes e Bases da Educação Nacional de 1961, o Conselho Federal de Educação estabeleceu que os currículos mínimos dos cursos de Licenciatura compreenderiam as matérias fixadas para o Bacharelado "convenientemente ajustadas em sua amplitude e estudos pedagógicos que habilitassem ao exercício do magistério nos estabelecimentos de ensino médio"35.

Estas alterações, desde 1946, significaram a redução da carga horária pedagógica em relação à carga total do curso, e o consequente aumento da carga das matérias de conteúdo específico, sendo incorreta hoje a designação " $3+1$ ”. Nas observações de Azanha (1991), o correto seria a designação "3 e 3/4 mais 1/4" 36 .

Em 1950, havia vinte e duas Faculdades de Filosofia no país. Dez anos depois, o número já triplicara. Após 1960, o processo de expansão das faculdades de filosofia se acelerou ainda mais, principalmente através da iniciativa privada ${ }^{37}$, podendo-se constatar que, hoje, apenas $7 \%$

\footnotetext{
${ }^{35}$ Parecer n⿳0 292/62.

${ }^{36}$ Azanha, J.M.P. In: Fórum da Licenciatura, 2, São Paulo : USP, 1991. p.39-40. Como a carga horária mínima das disciplinas pedagógicas é de $12,5 \%$, ela corresponde a $1 / 8$ do curso. A frase de Azanha, mantendo o seu aspecto crítico, deveria ser ".... 3 e $1 / 2$ mais $1 / 2$ ".

${ }^{37} \mathrm{Em}$ 1968, 46\% dos estudantes de ensino superior estavam matriculados em estabelecimentos privados, sendo que $3 / 4$ deles cursavam Licenciatura, Economia ou Direito. In: CANDAU,V.M.F. (Coord). Novos rumos da licenciatura. Brasília : INEP, 1987. p.15.
} 
dos mais de 200.000 professores que militam nas escolas públicas do Estado de São Paulo são formados por Universidades Estaduais ${ }^{38}$.

Caracterizando-se as Licenciaturas a partir de suas relações com o Bacharelado, três modelos podem ser definidos: o primeiro, o mais antigo, em que a Licenciatura consiste no Bacharelado acrescido de um conjunto de disciplinas pedagógicas; o segundo, Licenciatura e Bacharelado têm um núcleo inicial comum de disciplinas, bifurcando-se os currículos a partir de um determinado ponto e o terceiro, em que Licenciatura e Bacharelado são cursos separados.

O primeiro modelo é mais sujeito a críticas por estar nele subjacente o conceito de que para ensinar basta saber. Inicialmente o aluno cursa o Bacharelado, cujo objetivo principal é qualificá-lo para a pesquisa, e, em seguida, faz disciplinas pedagógicas. Em acréscimo, se apontam as inconveniências da falta de articulação entre as disciplinas pedagógicas e as específicas ${ }^{39}$, ou, pelo menos, ser ela precária. Além disso, há a tendência de inexistirem no currículo, disciplinas de conteúdo específico ajustadas à situação particular do ensino de $1^{\underline{0}}$ e $2^{\underline{0}}$ graus, como decorrência da própria prioridade dada, nesse modelo, à formação dos bacharéis.

Se a Licenciatura e o Bacharelado compartilham um núcleo curricular comum, com posterior bifurcação, as dificuldades apontadas referem-se à reduzida carga horária destinada às disciplinas pedagógicas (pouco mais de $1 / 8$ do total do curso); à precariedade da integração didático-científica, e também a que raramente são acrescentadas às disciplinas obrigatórias, outras voltadas para a formação do professor ${ }^{40}$.

Já para o modelo em que Bacharelado e Licenciatura apresentam estruturas curriculares paralelas e distintas são considerados os inconvenientes: provável duplicação de disciplinas idênticas para os dois $\operatorname{cursos}^{41}$; impossibilidade de trânsito de alunos de uma modalidade para

38PERALTA, J.J. Modernização dos currículos de graduação. In: Fórum da Licenciatura, 2, São Paulo : USP, 1991. p.31.

${ }^{39}$ Por disciplinas específicas entendo aquelas correspondentes à área do conhecimento a que se refere a habilitação do professor. Vários autores usam o termo "disciplinas de conteúdo", denominação que considero não apropriada, pois disciplinas pedagógicas também são de conteúdo (pedagógico).

${ }^{40}$ Ver, por exemplo, Tancredi, R.M.S.P. A formação do professor nos cursos de licenciatura da área de ciências da UFSCar: uma análise da questão sob a ótica dos licenciados. São Carlos: UFSCar, 1995. p.133. Tese (Doutorado em Educação).

${ }^{41} \mathrm{Em}$ alguns casos o número de disciplinas com denominação e carga horária idênticas chegam a atingir $80 \%$ do total. In: TANURI, L.M. et al. Articulação entre bacharelado e licenciatura na UNESP: uma proposta. Didática, São Paulo, v.19, p.42, 1983. 
outra e redução das possibilidades de envolvimento dos alunos da Licenciatura em pesquisas. É reconhecido, entretanto, como ponto positivo desse modelo, a possibilidade das disciplinas específicas expressarem, já desde o início do curso, um direcionamento para as questões de ensino, que é fundamental para o futuro professor. Essa situação, infelizmente nem sempre é viabilizada na prática ${ }^{42}$.

Traçado esse panorama das licenciaturas, é necessária a referência à Licenciatura diurna em Física, do IFSC, iniciada em março de 1988. A aspiração dos estudantes de São Carlos e região, bem como a opção profissionalizante para os alunos do Bacharelado, foram justificativas para a sua criação. Ela não se caracterizou como carreira no vestibular, mas sim, opção para o aluno ingressante.

Com o objetivo de descortinar as intenções e objetivos que levaram à criação do curso, consultei os documentos contidos no Processo de sua criação ${ }^{43}$ e realizei entrevistas com os dois docentes mais diretamente envolvidos com a proposta naquele momento: o Presidente da Comissão Coordenadora de Graduação (C.C.G) e o Assessor Didático do DFCM/IFQSC/USP.

Consulta ao Processo mostrou ter sido discutida inicialmente a criação das Licenciaturas em Física e em Química pela Comissão Coordenadora de Graduação, que após aprová-la, encaminhou ao Diretor do IFQSC uma proposta preliminar de currículo para as duas carreiras: Física e Química, além de enviar um ofício no qual destacou que "houve consenso a respeito da necessidade de buscar equilíbrio entre a boa formação básica do futuro professor e a sua indispensável formação pedagógica". Evidentemente, esse equilíbrio não é garantido, apenas, pela estruturação do currículo. A colocação acima transcrita deve ser entendida como tradução das aspirações da C.C.G., naquele momento.

O currículo foi composto pelas disciplinas do Bacharelado, com exceção de algumas que são dos últimos semestres letivos, e mais as seguintes: História da Física, Psicologia da Educação, Estrutura e Funcionamento do Ensino, Didática, Instrumentação para o Ensino e Astronomia e Astrofísica, nos termos, portanto, do Parecer $\mathrm{n}^{\mathrm{o}}$ 292/62, do Conselho Federal de Educação. Os quatro primeiros semestres da

\footnotetext{
${ }^{42}$ Ver, por exemplo, Tancredi, R.M.S.P. A formação do professor nos cursos de licenciatura da área de ciências da UFSCar: uma análise da questão sob a ótica dos licenciados. São Carlos: UFSCar, 1995. p.134. Tese (Doutorado em Educação).

${ }^{43}$ Processo IFQSC n ${ }^{\circ} 174 / 85$.
} 
Licenciatura e do Bacharelado eram comuns, bifurcando-se o currículo a partir do quinto período letivo, cujas disciplinas não comuns com o Bacharelado eram Introdução à História da Física e Psicologia da Educação I. No $6^{\underline{0}}$ período as disciplinas não comuns eram Psicologia da Educação II e Estrutura e Funcionamento do Ensino de $1^{\underline{0}}$ e $2^{\underline{0}}$ graus. No $7^{\circ}$ : Didática, Instrumentação para o Ensino de Física I e Prática de Ensino de Física I. No 8․: Prática de Ensino de Física II, Instrumentação para o Ensino de Física II e Astronomia e Astrofísica.

Em 30/05/86, a Congregação aprovou por unanimidade "após ampla discussão" a criação do referido curso ${ }^{44}$. Ofício encaminhado ao então Reitor da USP, destacou que a implantação do curso atenderia a uma "aspiração antiga dos estudantes da cidade", além de ser uma "opção profissionalizante para alunos do Bacharelado".

Depois de aprovada em todas as instâncias competentes, a Licenciatura diurna em Física passou a constar do Concurso Vestibular de 1988.

Deve-se destacar que na segunda metade da década de 80 , a Reitoria da USP passou a dar maior ênfase ao número de aulas atribuídas aos docentes dos Departamentos e das Unidades para autorização de novas contratações que implicassem no aumento do quadro docente. Sem querer atribuir a motivação para os novos cursos como decorrente do levantamento de indicadores (número de docentes por alunos e número de docentes por número de aulas semanais), deve-se, no entanto, colocá-lo como uma questão a ser considerada no quadro político-administrativo da Universidade.

Um segundo aspecto a ser considerado, no conjunto dos fatores que levaram à implantação das Licenciaturas, é a existência anterior de cursos de Bacharelado com um número reduzido de alunos e um número menor ainda de concluintes ao final dos anos letivos. Esse baixo número de alunos formados no Bacharelado parece ter influído na decisão da introdução do curso de Licenciatura como uma opção para o aluno ingressante.

As entrevistas com o Presidente da C.C.G. do Instituto, sobre as medidas que levaram à criação da Licenciatura em Física e com o Assessor Didático do Diretor do Instituto, descortinaram algumas posições

${ }^{44}$ Ata da 194ª sessão da Egrégia Congregação do IFQSC - fls. 022/86. 
dos docentes envolvidos e que não aparecem no processo oficial de criação do curso.

Segundo o Presidente da C.C.G. "o início da discussão sobre a Licenciatura foi marcado pela percepção da necessidade de se criar mecanismos aos estudantes que já tinham feito boa parte de disciplinas, mas que estavam desencantados com o Bacharelado, para que se pudessem formar na Licenciatura. Era uma saída simples, a de formar alunos, além de colocá-los no mercado de trabalho e beneficiar o $2^{\underline{0}}$ grau com professores que tinham tido e estavam tendo um curso de alto nível, com bons laboratórios, boa biblioteca, bons professores, enfim uma infraestrutura das melhores. Por estar estruturado da forma como estava, o Bacharelado era um curso difícil e que "prendia" o aluno por muito tempo. Sua saída, pela Licenciatura, beneficiaria a todos, principalmente os alunos do $2^{-}$grau da cidade" ${ }^{45}$.

Quais seriam os motivos do mencionado desencanto? Seria a carga didática exagerada? Ou uma abordagem desinteressante de um curso que dava pouca ênfase às aplicações mais práticas e mais cativantes dessa ciência? Ou, ainda, o fato de que seus professores, excessivamente preocupados com a pesquisa, descuidavam da prática docente?

Quanto ao curso ser considerado difícil, é preciso refletir sobre a questão das exigências de muitos pré-requisitos formais e de domínio anterior de conhecimentos, dificuldades estas desconsideradas, por vezes, pelo professor de uma determinada disciplina, preocupado muito mais com o cumprimento do seu programa de curso.

O Presidente da C.C.G. fez, ainda, referência ao fato de que sendo o campus de São Carlos constituído apenas de cursos de ciências exatas e tecnológicas, os alunos estariam se ressentindo da inexistência das humanidades. "A Licenciatura poderia suprir essa lacuna e abrir a possibilidade de uma capacitação não apenas técnica", ele afirmou. A procura e frequência à disciplina Psicologia da Educação, sob minha responsabilidade, nos anos de 1990 a 1995, por alunos optantes pela Licenciatura e alunos do Bacharelado, do Mestrado e até do Doutorado, viria, mais tarde, confirmar a percepção enunciada naquele momento.

"A Licenciatura aí está com o compromisso de garantir o alto conceito do campus de São Carlos. Além disso, tem o CDCC que é um

${ }^{45}$ Entrevista com o Presidente da C.C.G. do IFQSC. 
celeiro de atividades para alunos e professores da Rede Estadual", foram suas palavras, no final de 1990.

$\mathrm{Na}$ entrevista, o Assessor Didático esclareceu que pela montagem do curso de Licenciatura, "só seriam substituídas as disciplinas com caráter nitidamente técnico, que formam o aluno que vai fazer pesquisa em Física". Segundo ele, os dois primeiros anos letivos seriam idênticos: licenciandos e bacharelandos cursariam as mesmas disciplinas. No terceiro e no quarto ano "as disciplinas seriam substituídas por outras mais adequadas " 46 .

As disciplinas acrescentadas em substituição às técnicas, além daquelas de caráter pedagógico, foram: Tópicos de Física Contemporânea e Astronomia e Astrofísica, "a fim de preparar o futuro professor para enfrentar seus alunos num mundo tecnológico onde obtém informações por variados meios, mas nem sempre as compreendem bem". Aquelas disciplinas objetivariam "fornecer informações fundamentais sobre o Universo para serem trabalhadas pelas crianças e adolescentes" (dados da entrevista).

Nesta etapa dos estudos para criação da Licenciatura, existia a pretensão de que as necessidades fossem supridas com a colaboração da Faculdade de Educação da USP, devido à inexistência, no campus, de um departamento que abrigasse docentes das áreas pedagógicas. Posteriormente, entretanto, foram contratados dois docentes para as disciplinas de Psicologia da Educação e de Didática, alocados no Instituto de Física e no Instituto de Matemática, respectivamente.

Havia a intenção do Presidente da C.C.G. e do Assessor Didático, que eram os docentes mais envolvidos na criação e instalação da Licenciatura de Física no campus de São Carlos, de evitar os "erros que eram vistos em outras Licenciaturas, isto é, o curso deveria ter um nível compatível com outros cursos do campus", segundo enfatizaram.

$\mathrm{Na}$ mesma entrevista, entretanto, o Assessor Didático reclamava que crescia entre os docentes do DFCM, em meados de 1991, a sensação de que a Licenciatura deixara de atingir um dos objetivos que levou à sua criação, a saber, o de atrair mais alunos para o Instituto. Assim se expressou: "hoje é forte a corrente no departamento daqueles que acham que não tem significado toda a estrutura montada para trabalhar no vazio de alunos. As indagações acabam esbarrando nas questões de que talvez a

${ }^{46}$ Entrevista com o Assessor Didático do Conselho do DFCM. 
nossa Licenciatura assuste porque é difícil entrar no vestibular, ou a profissão de professor de $2^{-}$grau não seja atraente, ou talvez o número de pessoas interessadas na Licenciatura seja limitado e a UFSCar ${ }^{47}$ - que tem um curso de Licenciatura em Física - já as absorva, tradicionalmente. Como o IFQSC não fez divulgação do curso que criou, as pessoas desconhecem a Licenciatura diurna na USP. Portanto, provavelmente o departamento reabrirá brevemente essa discussão, tendo em vista esses problemas".

A "sensação" dos docentes, com certeza, referia-se muito mais à possível sobrecarga didática de alguns, do que ao curso não estar atraindo alunos, mesmo porque a medida utilizada foi o número de optantes em determinado momento e não o conjunto daqueles que concluíram a Licenciatura durante os anos de sua existência. Esse momento, aliás, foi bastante prematuro se for considerada opinião acima, emitida em meados de 1991, para um curso iniciado em 1988.

Com relação à estrutura montada, ela já existia e estava perfeitamente compatível. Seria, portanto, aproveitada e não seria para o vazio de alunos. Uma estrutura muito mais sofisticada tinha sido montada quando da criação do Bacharelado, que durante anos seguidos formou poucos bacharéis. Tal situação foi discutida e documentada em outro ponto deste trabalho.

Sobre a argumentação do não interesse pela profissão de professor, basta que se verifique, neste mesmo trabalho, o número de alunos da atual Licenciatura em Ciências Exatas em comparação com o Bacharelado e com o programa de Pós Graduação, ambos com existência anterior à Licenciatura.

Correta a constatação de que não houve divulgação do curso. Acredito que, propositadamente, a Licenciatura não foi divulgada. Levantamento que realizei junto aos alunos das Licenciaturas em Física, Química e Matemática, em 1991, quanto às dificuldades vividas naquele momento do funcionamento do curso, evidenciou a não divulgação e os motivos encontrados por eles. Apontaram a preocupação excessiva com as pesquisas e o exercício da docência por obrigação, além do fato da Licenciatura ser vista pelos docentes como um "curso sem importância", "pura perda de tempo" e "curso escolhido pelos alunos fracos".

Outro fator de má-receptividade pela Licenciatura, por parte de vários docentes, foi o fato de alguns alunos de pós-graduação em

\footnotetext{
${ }^{47}$ Universidade Federal de São Carlos.
} 
Física ou Química terem optado por cursar, simultaneamente, Licenciatura e pós-graduação. Foram vinte e cinco alunos, nove em Física e dezesseis em Química, no período entre março de 1990 a dezembro de 1995, que estavam cursando disciplinas ou elaborando a dissertação de mestrado ou elaborando tese de doutorado (foi o caso de um aluno). Na quase totalidade dos casos, não houve concordância de seus orientadores, que alegavam prejuízos para o bom desempenho na pesquisa que vinham realizando, devido à divisão do tempo entre os dois cursos, ou achavam a Licenciatura desnecessária, ou ainda, discordavam do direito dos alunos poderem fazer um curso de formação de professores. Discretamente, esses fatores exerceram pressão no sentido do não envolvimento maior dos docentes.

Em 1990, com o levantamento da demanda provável na cidade de São Carlos e região, tiveram início os estudos para a criação de um curso de Licenciatura noturno. Com a criação do Curso de Licenciatura em Ciências Exatas - Noturno, a Licenciatura diurna deixou de existir como opção para aqueles que ingressassem no Bacharelado em Física, excetuando-se os ingressantes até 1992.

Curiosamente, em 11/02/92, pela Portaria $\mathrm{n}^{\mathrm{o}}$ 273, o MEC concedeu "reconhecimento ao curso de Licenciatura em Física, ministrado pelo Instituto de Física e Química de São Carlos, da Universidade de São Paulo" 48 . No momento em que foi reconhecido oficialmente, foi também extinto. Esse fato confirma afirmação anterior quanto à prematuridade de uma avaliação superficial e descompromissada com o ensino.

\section{5 - A LICENCIATURA NOTURNA EM CIÊNCIAS EXATAS}

No segundo semestre de 1990, em atendimento à solicitação do diretor do IFQSC, que por sua vez atendia à Resolução n ${ }^{0} 3731 / 90$, da USP, quanto à implantação de cursos noturnos na Universidade de São Paulo, em cumprimento a artigo da Constituição Estadual, realizei levantamento junto a 3.293 pessoas, entre alunos de $2^{\underline{0}} \mathrm{e}$ $3^{\underline{0}}$ ano do $2^{\underline{0}}$ grau, $3^{\underline{0}}$ e $4^{\underline{0}}$ ano do magistério e professores $\mathrm{P} 1$, de 63 escolas da rede pública e particular, em São Carlos e região, que mostrou a

${ }^{48}$ Diário Oficial da União, 12/02/92, Seç I, p.1709. 
existência de demanda por um curso noturno de Licenciatura no campus de São Carlos.

Com base nessa Pesquisa de Opinião, que é o primeiro documento do Processo de Criação do $\mathrm{Curso}^{49}$, a Diretoria do Instituto nomeou uma comissão para elaborar proposta para criação de curso de Licenciatura noturna.

Em julho de 1991, a comissão submeteu ao diretor do IFQSC, a primeira forma de proposta do curso. Em versões posteriores, as ideias foram obtendo melhor adequação e a redação final foi aprovada pelos órgãos competentes nas várias instâncias da USP, sendo consequentemente, criado o Curso de Licenciatura em Ciências Exatas - Noturno - em 1993.

Faz-se necessário esclarecer que, embora estivesse ocorrendo na USP, em São Paulo, um Fórum de Licenciatura, a proposta do curso em São Carlos não se baseou no referido Fórum que, aliás, não chegou a um denominador comum, concluindo seus trabalhos pela liberdade e autonomia que deve ter cada unidade, respeitada a legislação em vigor. Uma frase retrata essa conclusão: "a liberdade é uma estratégia, um recurso útil para tratar no presente as coisas do futuro" 50.

Essa observação visa redirecionar a interpretação dada por Tancredi (1995, p.137), de que "um dos resultados deste Fórum foi a implantação em 1993, no campus de São Carlos, de um curso noturno (...) de Licenciatura em Ciências Exatas ...".

A Licenciatura em Ciências Exatas, curso noturno, teve, entre os motivos para sua criação, a demanda existente na cidade e região, além de dispositivo da Constituição Estadual e Portaria do então Reitor da USP.

Na proposta aprovada, e que está em vigor, o objetivo é o de propiciar "uma boa formação de professores e não formar especialistas em Física, Química, Biologia ou Matemática, função reservada aos cursos de Bacharelado e pós-graduação". O ensino, então, seria mais voltado "para a realidade científico-cultural dos dias de hoje, quando se dá ênfase ao conhecimento integrado". É, ainda, esclarecido no processo, que um dos desafios é o de "não formar generalistas ou superficialistas, engano já

${ }^{49}$ Processo USP n⿳0 90-1-795-54-4.

50VALLE Filho, M.R. Caminhos da licenciatura: presente do futuro. São Paulo: Jornal da USP, 17 a 23/02/1992. p.2. 
cometido pela Licenciatura curta no passado". A Licenciatura proposta visaria "à construção interdisciplinar do futuro docente do $2^{\underline{o}}$ grau, característica indispensável para o ensino nas próximas décadas" 51.

"O professor de Física no $2^{\underline{0}}$ grau é o bacharel ao qual apenas se forneceu alguma formação pedagógica, tornando-se necessária uma experiência num modo alternativo de formação que permita um ensino mais voltado para a realidade científica e cultural dos dias de hoje, quando se dá ênfase ao conhecimento integrado e interdisciplinar" 52 , fugindo da especialização docente. (p.1).

"Não é objetivo do ensino de $1^{\underline{0}}$ e $2^{\underline{\underline{o}}}$ graus formar especialistas em Física, Química, Biologia ou Matemática, mas é desejável que os egressos destes níveis de ensino tenham uma formação cultural e científica ampla que os capacite para a vida numa sociedade moderna, na qual as Ciências ocupam apenas uma parte” (p.1).

A Comissão afirmou entender que a maioria dos docentes que lecionam Física no $2^{\underline{0}}$ grau, em geral "são portadores de diploma de Licenciatura em Matemática, obtido em escolas superiores privadas, que não têm condições materiais (como laboratórios, bibliotecas) para oferecer um curso adequado". Em consequência, o ensino de Física no curso secundário é "uma atividade muito mal executada, sem conceituação adequada, sem experimentação, resultando num desinteresse dos alunos pela Ciência" (p.2).

A proposta da Comissão foi a de estruturar um curso de Licenciatura que formasse “docentes para o ensino de $1^{\underline{0}}$ e $2^{\underline{o}}$ graus com formação adequada para lecionar qualquer uma das disciplinas de Matemática, Física e Química para o $2^{\underline{0}}$ grau e Ciências Físicas e Biológicas para o $1^{\underline{o}}$ grau” (p.1).

Os pontos positivos para a instalação dessa Licenciatura no campus de São Carlos, apontados pela Comissão, foram a existência de laboratórios de ensino de Física bem equipados, biblioteca, a existência de outros Departamentos no campus (Matemática, Química e Hidráulica e

\footnotetext{
${ }^{51}$ Sobre a Proposta da Licenciatura em Física no IFQSC consulte-se Processo USP n⿳ํㅜ90-1-79554-4.

${ }^{52}$ Proposta de uma Licenciatura em Ciências Exatas, campus de São Carlos, 1992. mimeo.
} 
Saneamento $^{53}$ (este com atividades no campo da biologia) e o CDCC, com suas atividades de apoio ao ensino de $1^{\underline{0}}$ e $2^{\underline{o}}$ graus. Os laboratórios didáticos dos Departamentos e do CDCC, na visão da Comissão, permitiriam colocar a "ênfase [do curso] na formação eminentemente prática". Para isso, as aulas seriam "teórico-práticas, isto é, não havendo separação entre disciplinas teóricas e de laboratório", com o "trabalho experimental do licenciando (...) voltado para as necessidades do currículo secundário" (p.4).

A opção adotada pela Comissão para a montagem da estrutura curricular foi a de "ensino seriado", com as disciplinas anuais de Matemática, Física, Química e Biologia nos três primeiros anos, ficando o $4^{\circ}$ ano para disciplinas da área escolhida pelo aluno.

As disciplinas pedagógicas permeiam o curso a partir do primeiro ano, como é caso de Introdução às Técnicas Educacionais. É disciplina obrigatória, inovadora em curso de Licenciatura em ciências, oferecida nos três primeiros anos do curso. Tem os seguintes objetivos: desenvolver as habilidades orais e de escrita de material didático e científico, possibilitando ao futuro professor ensinar com clareza e propriedade, os conhecimentos de sua área.

As demais disciplinas pedagógicas, sucessivamente oferecidas nos anos seguintes, são desenvolvidas, tanto quanto possível, em integração com Introdução às Técnicas Educacionais.

As disciplinas optativas são destinadas "ao enriquecimento da formação dos licenciandos em áreas conexas ligadas ao ensino das Ciências" (p.5).

As disciplinas da Licenciatura são específicas para esse curso "não intercambiáveis com as do Bacharelado e não se concedendo equivalência com disciplinas de outros cursos" 54 (p.4).

\footnotetext{
${ }^{53} \mathrm{O}$ Departamento de Hidráulica e Saneamento da EESC mantem, às margens de uma represa próxima a São Carlos, o Centro de Recursos Hídricos e Ecologia Aplicada - CRHEA, com atividades no ensino de graduação, pós-graduação e extensão (cursos para professores de $1^{\circ}$ e $2^{-}$ graus) na área da Ecologia. Além disso, o CDCC utiliza a mesma área para excursões pedagógicas destinadas aos alunos de $1^{\underline{o}}$ e $2^{\underline{o}}$ graus. No relatório da Comissão, que estudou a implantação, o Departamento está incorretamente indicado como Departamento de Ciências Ambientais, que não existe no campus de São Carlos.

${ }^{54}$ Processos USP nºs 90-1-795-54-4 e 92-1-624-54-7.
} 
Realizado o primeiro vestibular, com 40 vagas, em 199293, com entrada única (o curso constou como uma carreira específica da FUVEST ${ }^{55}$ ), a cerimônia de instalação do curso noturno de Licenciatura em Ciências Exatas realizou-se em 15 de fevereiro de 1993, data em que as aulas tiveram início.

Atualmente 120 alunos estão matriculados na Licenciatura em Ciências Exatas, no período noturno.

${ }^{55}$ FUVEST- Fundação Universitária para o Vestibular, responsável pelos exames de admissão aos cursos da USP (e outros de escolas superiores do Estado de São Paulo, como da Universidade Federal de São Carlos e Escola Superior Paulista de Medicina, hoje Universidade Federal de São Paulo). 


\section{REPENSANDO A PRÁTICA DOCENTE}

"O homem é ainda o valor mais alto de um estudo psicológico e educacional”.

Juan José Mouriño Mosquera

Tendo em vista a definição da presente investigação - a prática docente no $3^{\circ}$ grau - a revisão na literatura permitiu o conhecimento das pesquisas, dos trabalhos e dos estudos teóricos que a têm enfocado. Inicialmente apresento pesquisas que tratam da questão pedagógica no $3^{\mathbf{o}}$ grau. Na sequência, apresento publicações feitas no formato de artigos ou comunicações em eventos educacionais e, posteriormente, reflexões teóricas que, atualmente, representam pensamentos sobre a questão das práticas efetivas. Representam, ainda, encaminhamentos que poderão vir a constituir-se em nichos para se repensar a prática docente do ensino superior. 
$\mathrm{Na}$ seleção das pesquisas apresentadas prevaleceu, em primeiro lugar, o fato de ser o ensino superior o seu foco central, no que se refere à questão pedagógica e, em seguida, o critério de pertinência e consonância com o meu estudo. Assim, foram consideradas as pesquisas de Grígoli, Tancredi e Masetto, que caracterizaram a prática docente do ponto de vista das concepções do professor sobre o ensino, como, principalmente, levando-se em consideração a opinião do aluno. Cunha e Pimentel evidenciaram, respectivamente, a prática do bom professor e o processo de construção pedagógica de professores diferenciados, contribuindo com importantes elementos de análise. Martins analisou a questão da importância dada à pesquisa na universidade, em detrimento da docência. Vasconcelos colaborou com a caracterização da prática docente universitária por professores-profissionais liberais. Behrens pesquisou a prática pedagógica do professor universitário frente aos desafios que se colocam à Educação do cidadão do próximo milênio. Foresti tem se preocupado com a formação pedagógica continuada dos professores do ensino superior. Ofereceu um protótipo de um sistema hipermídia de Educação à distância. Lima apresentou pontos relevantes sobre a criação artística que é a ação docente no $3^{-}$grau e para a qual converge toda a historicidade educacional da pessoa, desde os primeiros anos da escolaridade. É a memória educativa ditando os caminhos. Godoy também consultou o aluno, investigando seu ambiente de ensino preferido e as influências sobre sua aprendizagem no ensino superior. Os trabalhos estão descritos nas páginas seguintes.

Caracterizada a instituição como uma unidade universitária com atividades significativas em pesquisa e coerente com o objetivo de compreender a prática docente do professor/pesquisador em Física, buscouse conhecer os encontros e desencontros entre as atividades de ensino e de pesquisa.

O tema integração entre ensino e pesquisa é assunto polêmico. De um lado, no Brasil, a indissociabilidade entre ambos está afirmada na Constituição, nos Estatutos das Universidades, em Resoluções e Portarias. De outro, nas instituições universitárias, a indissociabilidade é só uma "tese, pois na prática cotidiana não há uma real vinculação, nem em nível de conteúdo, nem de análise de problemas” (Martins, 1989, p.143).

Martins propôs-se conhecer a percepção de docentes universitários da USP e da UF/Bahia sobre a relação ensino/pesquisa e avaliar as consequências dessa visão para o ensino superior de Física. 
Refletiu sobre o papel dos docentes como preparadores de novos quadros, apontando como problemática a convivência do trabalho de ensino e de pesquisa.

Demonstrou que: - a universidade faz forte pressão quanto à produção científica e não avalia a docência; - a maioria dos docentes declara que o grau acadêmico auxilia no exercício da docência na medida em que possibilita aumento da experiência e, portanto, proporciona maior "segurança na transmissão do conhecimento"; - a maior parte dos docentes não utiliza seus próprios artigos em sala de aula, ficando a programação restrita e sem o desenvolvimento do conhecimento no relacionamento com a pesquisa; - há desvinculação quase total entre aulas teóricas e práticas como se fossem disciplinas distintas; - "nenhum docente faz referência à formação, atendo-se à informação"; - não há preocupação maior com os métodos de ensino; - a avaliação segue a forma tradicional; - a avaliação de curso e/ou professor é verbalizada como questão importante; - a indissociabilidade entre ensino e pesquisa é utilizada nas respostas apenas como um jargão; - há primazia da pesquisa provocada pela Instituição e pelos interesses pessoais dos docentes.

A autora afirma que o ensino é tido como subproduto, tarefa obrigatória e "há demonstração explícita do desconhecimento de procedimentos usados em educação" (p.128). Há, no entanto,

"necessidade de que os docentes tenham consciência de sua condição de educadores e vejam a oportunidade dos conhecimentos na área educacional para que o ensino e a pesquisa possam "caminhar" lado a lado" (Martins, 1989, p.146).

Dos docentes do $3^{-0}$ grau das Universidades Públicas se espera que sejam bons, especialmente na pesquisa. É suposto que se forem bons pesquisadores, serão bons professores. No entanto, se não o conseguirem, seja por quais fatores e porque são diferentes as habilidades necessárias ao bom desempenho entre uma e outra atividade, deverão cuidar melhor da competência acadêmica. Serão analisados, avaliados, recontratados e mantidos por critérios da própria estrutura universitária que privilegiam a produção científica. $\mathrm{O}$ hábito da dicotomização é herança da mentalidade de compartimentalização do conhecimento e não de posturas mais diferenciadas que tratam das múltiplas variáveis intervenientes no processo de criação e apropriação do saber e fazer.

O status ganho pela pesquisa decorreu de fatores ou causas estruturais que, planejadamente ou não, contribuíram para o total 
desprestígio do ensino. Têm sido apontadas as exigências legais quanto à preferência por "títulos universitários e teor científico" 56 dos trabalhos de candidatos ao ingresso e promoção na carreira docente do magistério superior, e não-referência à formação pedagógica (Côrtes e Huerga, 1986; Lima, 1995).

As pesquisas empíricas sobre a Educação demonstram que seus autores, embora conscientes de que "somente uma sólida formação pedagógica não proporciona ao professor a garantia de uma ação docente eficaz”, questionam a não-exigência e não-valorização da formação pedagógica "àqueles que têm a responsabilidade de preparar pedagogicamente" os professores de $2^{\underline{0}}$ e de $3^{\underline{0}}$ grau (Côrtes e Huerga, 1986, p.76-77).

Reafirmam os aspectos já enfatizados quanto à importância da formação didático-pedagógica, ao lado da formação específica e quanto à crença relativa à suficiência conferida pela produção científica ao exercício profissional do ensino.

Os estudantes são defrontados, desde a sua formação, com problemas do conhecimento científico e em níveis cada vez mais avançados. Exercitam, sistematicamente, a busca do saber, ou seja a pesquisa. Assimilam a pré-concepção de que a preocupação pelo ensino é própria dos menos capacitados e que fazê-lo significa relegar a pesquisa ao segundo plano.

Os professores contratados pela universidade exercem a docência por obrigação contratual. Não gostam que se refiram a eles como bons professores porque há um senso comum enviesado de que a referência a alguém como bom professor dissimula a opinião de que ele não se distingue na pesquisa.

A fim de enriquecer a análise feita por Martins, enfocarei opiniões de Kourganoff (1990), Luna (1992), Demo (1993) e Terrazzan (1994) porque também sintetizam pontos que serão mencionados pelos professores do presente estudo.

Kourganoff (1990, p.299), discutindo o sistema francês de universidade, propugna que nem todos os professores universitários devem ser pesquisadores e que o "objetivo principal, a missão principal da universidade, torne-se a formação dos estudantes”. Para Kourganoff, a

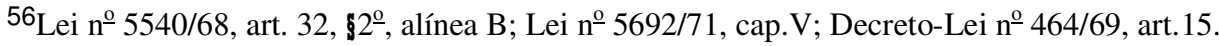


possibilidade de integração entre ensino e pesquisa depende do curso e especificamente da disciplina envolvida.

No Brasil, Luna (in: D’Antola, 1992), concorda com essa restrição, colocando-a como uma condição de dependência para poder-se dizer que o ensino se torna insustentável na ausência da pesquisa, não sendo, portanto uma regra geral.

Demo (1993, p.127), estende o conceito de pesquisa além do fabricar ciência, colocando-a como parte integrante do processo educativo, no sentido de ser atitude de questionamento crítico e criativo. Nesse enfoque, coloca a pesquisa na posição de "alma da vida acadêmica", afirmando que "tudo o mais pode ter imensa significação, mas não exige instituição, como a universidade, manifestações nem mesmo para apenas ensinar". Com a pesquisa como integrante do processo educativo, o autor propõe a iniciação à pesquisa - no sentido amplo por ele conceituado - em todos os níveis de ensino, com a consequente substituição do "ensinoaprendizagem" pelo "aprender a aprender".

Deve-se ressaltar que Kourganoff (1990, p.71), apesar de suas críticas ao primado da pesquisa, também considera a possibilidade de iniciação à mesma, dependendo da disciplina, precocemente, ou seja, desde o início e durante todo o processo educativo.

Nos cursos que envolvem conhecimentos de longa duração, na opinião de Kourganoff, o ensino é estruturado partindo-se dos conceitos básicos ou clássicos. Eles são imprescindíveis tanto porque estão presentes nas mais variadas aplicações tecnológicas, como porque são necessários para a compreensão dos conceitos mais atuais que serão utilizados pelos futuros pesquisadores. A necessária participação das disciplinas "clássicas" na estrutura curricular do curso de Física leva a um natural distanciamento entre os seus conteúdos e as atividades de pesquisa, desenvolvidas pelos docentes.

Para Kourganoff, as atividades de pesquisa dos docentes são prejudiciais ao ensino. Um dos motivos alegados pelo autor é que "do ponto de vista do tempo disponível, uma intensa atividade de pesquisa (...) elimina as veleidades de uma atividade tendente a renovar o conteúdo (ou os métodos) de ensino".

Por outro lado, "a profusão de cursos esclerosados e de tratados ultrapassados é explicada (...) pela transformação de 
docentes em pseudo-educadores, devido a uma orientação muito imperativa que impele à pesquisa” (p.153).

Por ter a crença de que a aquisição de condições mais satisfatórias ou de motivação para a docência dependeria, primordialmente, de meios externos e de ter que se submeter a um curso - de preferência que fornecesse as receitas - o professor esquiva-se de buscar em si mesmo e na própria atuação atenta, diferenciada e reflexiva, a apropriação já mencionada.

Na docência, nem sempre os professores têm a tomada de consciência do processo que realizam. Nem sempre o submetem a uma reflexão cuidadosa, reveladora e tornada consciente.

As conquistas, individuais na quase totalidade das vezes, vão acontecendo e acabam por estabelecer formas de conduta e de condução do processo. Quando indagados, não raro precisam parar para pensar e mentalmente refazer o que fazem, a fim de responder.

Terrazzan (1994), ao falar sobre o professor e o conhecimento, apoia-se em dados de uma pesquisa "acerca das bases epistemológicas reais, subjacentes à sua prática pedagógica regular”, sustentando que é raro o professor, na sua prática docente, explicitar as suas convicções epistemológicas.

"É possível perceber que o professor tem, na verdade, uma epistemologia totalmente inconsciente". "O compromisso, mesmo inconsciente, com determinada epistemologia, tem forte influência na prática pedagógica do professor" (Terrazzan, 1994, p.95-96).

Os professores universitários quase sempre deixam de compartilhar com os colegas, as experiências bem sucedidas na docência, no dia a dia. É um trabalho que se tem realizado isoladamente e de forma anônima.

Talvez também, por este motivo, é que as pesquisas sobre a sala de aula do $3^{-}$grau estejam encontrando receptividade. Nos últimos anos, tem sido encontrar estudos - alguns deles serão apresentados aqui frutos de investigações quanto à prática docente no ensino superior, demonstrando que há boas experiências para socializar. 
Além disso, há iniciativas que, embora necessitem passar por avaliação de seus propósitos reais em termos de política universitária e de verificação acurada de seus resultados, devem ser mencionadas.

Uma delas - vale enfatizar - é o atual Programa de Aperfeiçoamento do Ensino ${ }^{57}$, instituído na USP em 1992, proporciona ao aluno que já integralizou $80 \%$ dos créditos de pós-graduação, a oportunidade do aprimoramento da sua formação através de estágio supervisionado em atividades didáticas de graduação. O objetivo da participação do aluno é oferecer-lhe preparação pedagógica apoiando o ensino de graduação (art. $1^{\underline{0}}$ e $3^{0}$ ). Embora de forma localizada, é uma experiência que parece demonstrar interesse institucional pela instrumentalização prática na docência.

A sala de aula no ensino superior, vista pelos próprios alunos, é tema palpitante. Grígoli (1990) elegeu como objeto de estudo de sua pesquisa o fazer didático do docente universitário, dentro das dimensões do saber, saber ser e saber fazer, privilegiando a palavra do aluno quanto às características, comportamentos e atitudes dos professores.

Os atributos que poderiam ser apresentados pelo professor, na sala de aula - espaço que ela denominou de "síntese das múltiplas determinações"- relacionaram-se aos seguintes: - domínio que demonstra ter da disciplina que leciona; - domínio dos aspectos didático-pedagógicos do trabalho docente; - dimensão interpessoal do seu relacionamento com os alunos; - visão que ele demonstra acerca da dimensão política da ação docente; - compromisso profissional com a docência; - desenvolvimento dos alunos no que se refere à sua independência e autonomia intelectual.

A pesquisadora agrupou os dados resultantes das respostas, em função do significado dos seus conteúdos, em dois conjuntos que foram

"trabalhados no sentido de evidenciar as representações dos alunos acerca dos professores que gostariam (e dos que não gostariam) de encontrar na sala de aula da universidade, em confronto com as representações que têm acerca dos professores que efetivamente encontram" (Grígoli, 1990, p.116).

${ }^{57}$ Inicialmente Programa de Iniciação ao Ensino Superior, Portaria GR-2794 de 19/11/92, publicada no D. O. E. de 20/11/92, seção I, 102 (220). Em 1994 passou a chamar-se Programa de Aperfeiçoamento de Ensino, através da Portaria GR-2906 de 09/08/94. 
As características, comportamentos ou atitudes que os alunos consideram mais importantes, mais positivos e mais desejáveis de serem encontrados nos professores, formaram um conjunto de quinze atributos, detalhados pela pesquisadora em termos das suas pontuações, inter-relações e interpretações. Foram, também, evidenciados os aspectos objetivos/operacionais de cada um dos atributos. Eles foram apontados por 93 a 97\% dos alunos e se referiram às condições desejadas pelos mesmos no que diz respeito à prática docente na universidade.

Nesse sentido, eles serão aqui transcritos: - gosta de ensinar e considera importante o seu trabalho; - conhece profundamente a disciplina que leciona; - estimula os alunos a se tornarem independentes; - organiza e conduz o ensino visando autonomia intelectual do aluno; - aceita as dificuldades e limitações do aluno; - é autêntico e honesto no seu relacionamento com os alunos; - dá aulas em linguagem clara, fácil e informal; - organiza e conduz o ensino sem colocar-se como "dono do saber"; - é cordial e amistoso no seu relacionamento em sala de aula; - cria condições para uma visão crítica da realidade e da profissão; - organiza avaliações que requerem capacidade de organizar o conhecimento; - demonstra segurança e domínio de si na condução do ensino; - procura transmitir mais que o conteúdo e estimula para um ideal; - usa um roteiro flexível para a aula e estimula a participação; - faz retomadas do assunto em estudo e sínteses globalizantes.

Deste trabalho resultaram os pontos críticos que foram sistematizados nos seguintes enunciados:

“- O compromisso com a docência é a questão central da prática pedagógica.

- A ação didática competente supõe o domínio do conteúdo específico e dos meios que favoreçam o seu ensino e aprendizagem.

- O desenvolvimento independente e a autonomia intelectual dos alunos são pouco contemplados pela prática pedagógica na universidade.

- As relações interpessoais são entendidas pelos alunos como mediadoras da qualidade da prática pedagógica.

- O desenvolvimento de uma visão mais ampla da sociedade e o entendimento crítico da realidade e da profissão são aspectos pouco articulados na prática pedagógica” (Grígoli, 1990, p.201). 
Seu estudo sobre as relações que se estabelecem na sociedade e na universidade permitiu a caracterização da prática educativa como sendo de legitimação-reprodução. No entanto, apresentou apontamentos que ampliam "o processo de repensar globalmente a função docente, na perspectiva de caminhar para a construção de uma pedagogia universitária transformadora" (p.5).

\section{Propôs}

"uma prática pedagógica que, fundamentando-se numa visão progressivista de universidade, seja capaz de pensar a especificidade de uma disciplina $e$ equacionar conteúdos, formas de trabalho, de avaliação, de comunicação e de participação na instauração de um ritual que intencionalmente esteja apontando e construindo os caminhos de uma ação transformadora" (Grígoli, 1990, p.38).

Para tanto, e ressaltando que não se trata, absolutamente, de substituir discursos, mas de pôr em ação formas didáticas que levem o aluno a exercitar a postura de sujeito da própria aprendizagem, elencou diretrizes necessárias: - o ser humano enquanto ser político; - a competência é via de acesso à participação social; - as relações interpessoais presidem todo o processo educacional, porém não numa perspectiva romântica, e sim democrática; - a questão metodológica, permeada pela questão da autonomia, deve organizar o trabalho pedagógico de modo a articulá-lo às finalidades sociais mais amplas; - planejamento, execução e avaliação são oportunidades fundamentais "para a tomada de decisões que expressem compromisso fundado num projeto filosófico-político de transformação claramente definido"; - o trabalho coletivo está na base da construção de uma prática pedagógica transformadora (p.78).

Quanto à interação não romântica e sim democrática, eu diria tratar-se de uma relação interpessoal na perspectiva que, reconhecendo que naturalmente o vínculo pedagógico é de dependência, deve caminhar no sentido da ruptura que leva à autonomia, segundo Bohoslavsky (in: Patto, 1985).

Entre as perspectivas e desafios que se colocam para repensar o ensino e a prática pedagógica, Grígoli destaca, ao concluir, que o aluno é elemento fundamental e é preciso ouvi-lo.

Tenho ouvido, nas minhas aulas, as "falas" de alunos sobre o despreparo pedagógico dos seus professores, a exigência excessiva e mal 
correspondida, o descaso pela docência, a despreocupação quanto às relações humanas, entre outras. A pesquisa de Grígoli (1990, p.200) evidenciou e deu corpo sistematizado à realidade de que "os alunos não têm voz na universidade, não têm a palavra nem o espaço para refletir $e$ falar sobre o ensino".

Tancredi (1995) também deu voz aos alunos. Avaliou a formação do professor nos cursos de Licenciatura em Ciências Biológicas, Química, Matemática e Física, por meio de questionários que os licenciandos responderam quanto ao seu processo de formação, à organização curricular, à contribuição das disciplinas específicas e pedagógicas, às experiências vividas e à atuação dos professores, a fim de:

"verificar como se dá esta formação em termos das exigências que se colocam para a escola e para a atuação dos novos professores", "conhecer como os licenciandos percebem estes cursos frente à realidade social e às suas futuras necessidades de atuação profissional", (...) "estabelecer algumas relações entre o trabalho de formação que se desenvolve nas Licenciaturas e a possibilidade de atuação competente e diferenciada dos egressos como professores nos três níveis de ensino", [e] "oferecer subsídios para as diferentes Coordenações de Curso” (Tancredi, 1995, p.7-27 passim).

Sobre a opinião dos alunos, a pesquisadora verificou que "entre as características atribuídas a um bom curso de Licenciatura, os licenciandos destacaram os aspectos relacionados às matérias pedagógicas e à atuação dos professores” (p.280).

Nas características da "Dimensão Professor", chamaramme a atenção especialmente aquelas que, no meu trabalho, foram perguntadas aos professores e também foi observada sua ocorrência ou não, nas salas de aulas. São as seguintes: - o professor é experiente; - tem grande conhecimento; - esclarece seus objetivos; - relaciona-se bem com os alunos; - é coerente na fala e na ação; - aceita e valoriza os licenciandos; - ajuda a planejar aulas; - incentiva discussões; - dá aulas dinâmicas e estimulantes; - seleciona métodos diferentes (p.285). No meu caso elas se referiram às categorias Planejamento, Características do Professor, Docência, Interação e Dimensão Pessoal/Profissional. 
Com relação às disciplinas, no que respeita à questão curricular, embora esta não seja de interesse fundamental para o meu trabalho, considero particularmente feliz a constatação da autora quanto ao fato de ser

"nítida a diferença nas respostas dadas pelos alunos que tinham experiência elou cursavam Prática de Ensino, sobre os aspectos relevantes para a formação de professores, pois é nesta disciplina e neste momento do curso que os primeiros contatos com a profissão e com as atividades docentes começam a ser realizadas. Este grupo de respondentes destacou, com unanimidade, as atividades práticas e de aproximação com o campo profissional como os aspectos mais relevantes para a formação $e$ a atuação de professores ..." (Tancredi, 1995, p.320. O grifo é meu).

No meu trabalho, a categoria Experiências Anteriores, no foco Monitor, recebeu relatos sobre tal importância.

No trabalho de Tancredi, os alunos que não tinham experiência enfatizaram as matérias pedagógicas nos aspectos psicológicos e metodológicos.

No "Fazer Docente", sua pesquisa evidenciou, nos respondentes, aspectos da atuação docente competente e dos modelos a que estão sujeitos os licenciandos. São eles: - a promoção, pelo professor, de discussões na classe, em que os alunos tivessem oportunidade da participação; - variação da metodologia de ensino no sentido de estratégias e de relacionar-se bem com os alunos; - coerência entre a teoria e a ação; - aplicação do conhecimento; - domínio do conteúdo e - habilidades técnicas de ensino.

A pesquisadora organizou tais focos nas "Dimensões": "Habilidades Docentes", "Habilidades Técnicas", e "Características Pessoais". Nas primeiras incluem-se o conhecimento e o trato da matéria de ensino, a reflexão sobre e em ação, a avaliação do trabalho realizado. Nas segundas, estão presentes aquelas que só podem ser desenvolvidas por professores que dominem o conhecimento a ensinar e, finalmente, nas últimas se inclui um "modo de ser como homem que auxilia o ser professor" (grifos da autora, p.403).

Suas conclusões "não definitivas" apontam que 
"um currículo para o futuro, muito especialmente nos cursos de Licenciatura, dever-se-ia basear em concepções de educação, de ensino, de aprendizagem e de currículo ... que se pautassem nos estudos mais recentes sobre o papel da escola e do professor, sobre as necessidades e características da atuação profissional, sobre o pensamento prático e reflexivo dos professores" (p.429).

Apontam, ainda, que "se a função da universidade é auxiliar os alunos a compreenderem o mundo, a perceberem como a ciência pode responder aos novos desafios da realidade, a atuarem de forma competente no exercício profissional, é preciso não desconsiderar a opinião dos licenciandos ...” (p.429).

Masetto (1982, 1990, 1991, 1995), também se preocupou com o aluno. Demonstrou que "em sala de aula de $3^{\underline{0}}$ grau, ainda se aprende ..." 58 , através da identificação e testagem de condições facilitadoras ao alcance dos professores e capazes de envolver, motivar e interessar o aluno com relação ao processo de sua aprendizagem.

Encontrou situações e resultados positivos quando a sala de aula é um espaço de "con-vivência", entendida a "vivência" como "vida" com conotação de "realidade".

"A Sala de Aula-vivência funciona como um espaço aberto impregnando-se de realidade num movimento de mão dupla: recebendo a realidade, trabalhando-a e desenvolvendo-a enriquecida com o conhecimento e a ciência" (Masetto, 1991, p.92).

A participação "com" inclui colegas, professores e grupos humanos fora da universidade a fim de produzir conhecimentos e fazer ciência com ... . A sala de aula entendida pelo pesquisador "se concretiza na modificação da postura do Professor de "ensinante" para "estar com"; de transmissor para a atitude de troca, através de uma ação conjunta do grupo", ou seja, a construção da prática docente com a preocupação da

${ }^{58}$ Título de sua Tese de Livre-Docência. São Paulo: F.E./USP, 1991. 
educação de um profissional, muito mais do que treinamento para o exercício de uma profissão (p. 96).

A educação/formação, ao lado da instrução/informação, tem se constituído em preocupação por parte dos professores nos graus de escolaridade anteriores ao curso superior. $\mathrm{Na}$ universidade é suposto que suas funções específicas, na docência, são a preparação/treinamento.

Nesse sentido, o professor é o transmissor do conhecimento elaborado, sistematizado pela ciência. Enquanto pesquisador, ele é entendido como produtor do conhecimento, muito embora no momento atual a produção do conhecimento não seja mais exclusividade apenas da universidade. A opção para "estar com" e "ser ensinante" e aprendiz ao mesmo tempo, vai em direção diametralmente oposta àquela em que o professor-pesquisador navegou durante o seu curso e na qual sente "pés firmes na terra" e certeza da chegada. A reflexão quanto a uma possível mudança de postura precisa ser enfrentada.

Masetto tem realizado este enfrentamento, desde o seu início como professor universitário, seja questionando, seja apresentando propostas de modificação da atividade docente, seja delineando novas orientações para os setores de pós-graduação, visando a uma melhor formação de docentes para o $3^{\underline{0}}$ grau seja, principalmente, realizando experiências concretas.

Tais experiências aconteceram (e acontecem) inclusive com estudantes e professores oriundos de cursos das áreas Exatas e Biológicas, demonstrando, em primeiro lugar, que não é apenas nas disciplinas da área de Humanas que as atuações diferenciadas têm condições de ocorrer e, em segundo, que a preocupação com a aprendizagem de adultos universitários também tem sua hora, vez e significância. "Aprender a se relacionar com os alunos como adultos, parceiros e co-responsáveis" (1995, p. 58).

A interação professor-aluno tem sido, aliás, o aspecto preponderante nas suas preocupações e atuações. Sua proposta é a de garantir um "clima de sala de aula" descontraído, de participação e com respeito mútuo. "O professor e o aluno, interagindo, formam o cerne do processo educativo". Essa dimensão assume força tal que "a aprendizagem do aluno pode ser mais ou menos facilitada, orientada mais para uma ou outra direção”, conforme a qualidade dessa relação (1990, p.113).

Nos nove princípios que Masetto (1991) propõe como condições facilitadoras da aprendizagem, a essência, no meu modo de ver, 
está no processo de interação que se estabelece, pois somente por meio da relação satisfatória entre professor-aluno e aluno-aluno, é possível: - promover a participação; - considerar as experiências e as contribuições dos alunos; - levar à explicitação de significados de vida e de conhecimentos intelectuais; - identificar necessidades, interesses e expectativas; - definir conjuntamente objetivos e estratégias; - decidir o sistema de avaliação; - desenvolver a consciência crítica; - estabelecer o contrato psicológico que equilibre necessidades do aluno com as propostas do professor, e finalmente, - engajar o professor num processo de aprendizagem próprio de adultos, só é possível por meio da relação satisfatória entre professor-aluno e aluno-aluno.

Em 1982, Masetto já chamava a atenção para aspectos fundamentais quanto ao "professor no ensino superior brasileiro" (p.110). Ao apresentar os depoimentos obtidos em experiências concretas realizadas com docentes universitários, enfatizou os seguintes:

- "a percepção do professor de que não é suficiente preocupar-se com a didática é é preciso que sua maior preocupação seja com a aprendizagem do aluno; - a percepção de que, neste sentido, o curso serve para localizar problemas e dúvidas sobre o desempenho da função do professor de $3^{\underline{o}}$ grau e não para apresentar soluções; - a percepção do caráter aleatório com que, em geral, os professores de ensino superior conduzem seus cursos; - a percepção de que é necessário perguntar-se: para que serve minha disciplina dentro do curso? Quais são os objetivos? Quais são as modificações que, à luz destes objetivos, minha disciplina precisa receber?; - a percepção da necessidade de real envolvimento com o aluno, de real flexibilidade no relacionamento com ele e da importância da delimitação dos objetivos de aprendizagem e de sua clara comunicação aos alunos; - a percepção de que o que foi iniciado no curso deve ter uma continuidade ao longo do semestre e dos anos. $O$ desempenho tradicional do papel do professor de $3^{\underline{o}}$ grau encontra-se muito arraigado (congelado) nos docentes. $O$ descongelamento exige tempo, perseverança $e$ continuidade de atitude diferenciada. Como conclusão, a percepção da perspectiva de ser o professor de $3^{o}$ grau, em primeiro lugar, um educador, e perceber que é possível $e$ 
operacionalmente realizável uma mudança de seu desempenho”.

os professores,

Foi evidenciado por Mattos (1994, p.4) que, de modo geral,

"têm tido uma postura institucional 'infantilizada' como se não fossem profissionalmente capazes de pesquisar suas próprias práticas, ou resolver seus próprios problemas no campo pedagógico. Em relação às suas próprias práticas pedagógicas, os professores consideram-se, na maioria das vezes, despreparados".

Esta colocação chamou-me a atenção porque alguns professores manifestaram de diferentes formas, esta postura no meu estudo. Não a caracterizo como infantilizada e tenho o propósito de compreendê-la, sem rótulos. As colocações atuais de Masetto quanto à possibilidade dessa mudança, acima citada, levam-me a refletir.

Um dos aspectos foi que, com exceção de um dos professores, que fez também Licenciatura, os outros relataram não ter formação pedagógica para ensinar. Ensinavam como viram seus professores fazendo, ou baseados no bom senso, mas nunca haviam pensado sobre a própria prática e nem se perguntado sobre as "coisas" que eu perguntava. Falavam assim, como se um segredo, não revelado a eles, fosse a chave à qual não tiveram acesso. Exemplifico com a transcrição da verbalização de um dos professores ao final das entrevistas: "As perguntas que você me fez, nunca ninguém fez. Eu nunca parei para pensar e formalizar o meu pensamento a respeito dessas coisas. Todo mundo tem uma noção básica dos assuntos e esta é a que eu tenho. Eu não sei quão precisas foram as respostas, quão valiosas elas possam ser".

Fico pensando e acredito que serão capazes de pesquisar a sua prática se a isto se propuserem e de resolver seus problemas ou as situações que ocorrem, pois eles o têm feito nas inúmeras micro-decisões que tomam na atuação docente. No entanto, a não reflexão parece tornar suas decisões e experiências como se fossem mecânicas, aleatórias e sempre iguais. Faz com que sintam assim. Outro aspecto foi que, por ser pedagoga, eles disseram que eu "sabia dessas coisas de didática", como se eu tivesse receitas, mas eles não, e assim, estão isentos da sua própria construção. Acredito até que não pensam a prática como construção própria. 
O planejamento, a formação pedagógica, a concepção de ensino, de aprendizagem e de avaliação, as características do professor, seus conhecimentos e habilidades, a experiência, seus valores - entre outros componentes (categorias) que são tratados nos diferentes trabalhos, e que verifiquei também nas entrevistas e observações que realizei - têm a concepção teórico-prática caracterizada pela opção didático-metodológica do professor.

$\mathrm{O}$ que mais influencia o professor nesta opção e consequente atuação? Cunha (1994) encontrou que as principais influências sobre os professores são provenientes de sua história como aluno. Destacou, ainda, a relação com seus ex-professores, tanto no sentido de repetir comportamentos positivos, como de rechaçar os negativos, a troca de experiências com colegas docentes, a construção do saber na própria experiência docente (a prática é muito importante e a experiência é insubstituível), a formação pedagógica, a prática social e o modelo dos professores que admira.

A constatação da influência da prática cotidiana levou a autora a alertar para a revisão da formação prévia, e favorecimento de ações e situações extensivas ao professor em exercício.

Ela estudou o que determina o desempenho do professor na prática de sala de aula aprofundando estudos sobre sua história de vida. Analisou o que acontece na prática pedagógica e porque acontece. Conheceu a imagem que o professor tem de si mesmo e no que ela interfere na atuação docente. Investigou como é o professor e o que foi mais importante na sua formação.

Compreendeu que o sucesso do bom professor, na expectativa dos alunos de hoje, na consideração da sociedade ao longo da história e no próprio papel que ele se atribui, está "assentado numa perspectiva de ensino que tem no docente o centro do processo de ensinar e aprender" (p.167).

A necessária vivência de experiências para que se dê a construção da prática docente possibilitou-lhe propor modificação do paradigma que existe atualmente nas concepções escolares, deslocando para o aluno a produção do conhecimento no exercício teórico-prático. Ressaltese, porém, que não pretendeu constituir "um paradigma do desempenho docente" (p.158). 
Constatou que para os estudantes, o ponto fundamental é o relacionamento professor-aluno. As relações devem ser entendidas pelo lado afetivo. O bom professor na interação que estabelece, é também bom na prática docente. Há uma estreita vinculação, no julgamento dos alunos.

Formulou, ainda, que o ponto fundamental, para os professores é a necessidade que eles mesmos têm da ação, da participação dos alunos. Seu "fazer" é intuitivo e por isso não há relações claras entre a prática e a teoria. A prática repete a prática. $\mathrm{O}$ projeto individual tem mais força que o projeto institucional.

$\mathrm{Na}$ dimensão pessoal/profissional " se o professor refletir sobre si mesmo, sua trajetória profissional, seus valores e crenças, suas práticas pedagógicas, encontrará não-semelhantes (em si mesmo), ao longo do tempo" (p.24). Esse aspecto foi também encontrado nas respostas dos meus professores. Realmente supõe-se que ocorram fatores de modificação e haja dinamismo nos profissionais de modo geral e no professor em particular, já que ele pode ser o construtor do seu caminho como educando e educador, nas múltiplas micro-decisões que toma na sua sala de aula e na intencionalidade e direcionamento que pode imprimir ao seu fazer educativo.

Chamou-me a atenção, concepções no estudo de Cunha dela ou dos sujeitos da sua pesquisa - que foram focos de questões e/ou observações no meu estudo e aqui só serão mencionados, como por exemplo: - a atitude não contemplativa ou absorvente do aprender (concepção de aprendizagem); - a união entre ensino e pesquisa (binômio ensino/pesquisa) para que a educação seja integrada e ato partilhado de criação do conhecimento; - o significado das experiências anteriores e atuais na construção do cotidiano (experiências anteriores); - o "exemplo como a principal forma de ensinar" (p.128); - os conhecimentos e habilidades conquistados influenciando escolhas (e aqui o destaque da autora para alunos bem sucedidos nos graus anteriores da escolaridade encaminhando-se para o magistério, foi ponto de reflexão sobre se a atuação como monitor ou estagiário de programas de iniciação ao ensino ou outra(s) modalidade(s), influenciam e garantem condições melhores para a docência superior); - as limitações, idealizações e expectativas: "os professores reconhecem que enfrentam dificuldades e que nem tudo é prazeroso na docência" (p. 86); - os modelos de ex-professores e a reprodução de comportamentos, com os aspectos positivos desse fato, mas também os riscos da repetição sem reflexão e sem tomada de consciência; o planejamento, a execução e a avaliação não socializados, não 
coletivizados; - o compromisso/comprometimento que se manifestam na forma de ser e de agir do professor.

Pimentel (1994, p.21), investigou "quem é e o que faz o professor comprometido com o ensino e quais são suas motivações primeiras". Seu objetivo foi evidenciar o processo de construção profissional dos docentes universitários pesquisados, considerados bem sucedidos por seus pares e alunos.

professores:

Evidenciou, por um lado, a prática educativa dos

"que seguem um paradigma de conhecimento $e$ ensino pós-moderno, onde o conhecimento é visto como construção", [e por outro, a prática] "dos que têm como paradigma de conhecimento e ensino o da ciência moderna, e vêm o conhecimento como um produto" (Pimentel, 1994, p.21).

Traçou ainda, o panorama da "combinação de posições emergentes e tradicionais, características de uma época de transição" (p.35).

Independente de rotulações, essas configurações referem-se a um grupo voltado à transmissão do conhecimento, outro preocupado com inserções sociais mais amplas e um terceiro que se localiza, pelas suas atuações, entre os dois primeiros grupos.

Afirmou que os professores percorrem um caminho de conscientização, interferindo "intencionalmente por serem, também, seres livres e sujeitos". Embora todos tenham o domínio do conhecimento, nem todos "têm o conhecimento da produção do conhecimento e poucos têm o conhecimento clarificado e consciente do que é ensinar” (p.83). Diferenciou quanto às habilidades didáticas, quais correspondem ao "bom" ensino tradicional e quais se apresentam nos professores "pós-modernos emergentes".

Para a autora, a vida universitária como um todo proporciona, mais do que a sala de aula, aprendizagens responsáveis pelo desenvolvimento humano, social, cultural, intelectual, e aquisição das condições para a vida profissional. 
Ela identificou na fala dos alunos, três dimensões quanto ao professor: dimensão dos conteúdos, dimensão das habilidades (instrumentos técnicos e metodológicos) e dimensão das relações situacionais (os aspectos da vida universitária como um todo).

De posse dessa identificação, a autora questionou-se sobre se a docência que é valorizada, estaria em desarmonia com o extra-classe, se os alunos se prendem a uma representação tradicional dos professores e valorizam suas técnicas e conhecimentos, se lhes faltariam condições da prática das dimensões social e político-libertadora.

Reuniu suas construções em dois temas: "O professor $n a$ transição do paradigma científico dominante - posições emergentes e tradicionais" e "O professor e suas motivações primeiras - a busca de sentidos na experiência do ser".

Formulou que "na prática educativa dos professores pesquisados na UNICAMP vive-se, em todas as suas nuances, a crise do paradigma científico moderno. Há os que rompem com o conceito moderno de ciência e conhecimento. Partem, através da crítica e da criatividade, para a construção de novas formas de ensino. Criam seus próprios paradigmas emergentes, pós-modernos, simultaneamente científicos e sociais. Procuram não trabalhar com as dicotomias tradicionais, características do paradigma dominante. Abrem trilhas, ensaiam, experimentam, ousam. Sofrem em suas vidas, na sua condição existencial, as repercussões da condição epistemológica da ciência: mudam sua concepção de vida, de homem, de sociedade, de conhecimento e de ensino. Não têm certezas, mas buscam em sua práxis a coerência das verdades descobertas" (...)

"Outros, muito bem-sucedidos em suas pesquisas com o paradigma da ciência moderna, não têm percepção da crise instalada. Para eles, não há paradigma emergente. Concebem o conhecimento como um saber pronto, fechado em si mesmo, um produto organizado $e$ estruturado sequencialmente, que deve ser transmitido por tópicos menores" (...). "Entre os dois polos, estão os professores que vivem um tipo de transição. Vivem a coexistência dos 
paradigmas dominante e emergente" (Pimentel, 1994, p.34-35).

Os professores do paradigma emergente, pós-moderno, são identificados nos seus discursos pelos verbos questionar, sentir, inovar e outros, que explicitam comportamentos distantes do ensino do imobilismo, do fragmentário, do pensamento convergente, da alienação, da passividade, do congelamento do real. Aponta que

"estes professores estão dizendo que mudar espaço de ensino não significa apenas mudar a metodologia ou adotar os procedimentos de um professor bemsucedido... Significa questionar profundamente as próprias posições filosóficas, epistemológicas, políticas e ideológicas” (p.37).

$\mathrm{Na}$ "coexistência de paradigmas", a autora relatou os procedimentos dos professores, que ensinam por meio de situações práticas em que o aluno atende, exercita e realiza, buscando soluções, mas esses professores parecem não unir o que se passa na prática com a teoria, pois nas aulas, prendem-se à tradição.

Ensinando na certeza do paradigma dominante os "professores, na sua prática de ensino, adotam o conceito de conhecimento como um todo construído e organizado, um bem que se deve alcançar assimilável se dividido em parcelas menores, em 'tópicos' que se constituem numa cadeia de pré-requisitos, sem os quais não se alcança um saber mais elevado” (p.63).

Com "O professor e suas motivações primeiras", a pesquisadora faz considerações sobre o fato de que "as concepções de conhecimento, ciência e ensino são parte da concepção de vida e mundo construídos pelos professores em sua trajetória”. Eles "fazem diferentes interpretações de "como" e "pelo que” são responsáveis, segundo sua visão de mundo, história pessoal, cultural e origem familiar” (p.75 e 78).

Importantes considerações são feitas sobre: "o modelo de racionalidade que preside a ciência moderna” (p.32), a relação adulto/adulto, recursos e técnicas utilizadas, preparação de planos de curso e aulas, ensino e pesquisa, características dos professores e docência (domínio do conteúdo, habilidades didáticas, concepção de ensino e de aprendizagem). 
Vasconcelos (1994, p.2), acrescenta dados interessantes ao trabalho de caracterização da prática docente na universidade, ao apresentar o profissional liberal que também atua como professor em cursos superiores. São profissionais de várias áreas específicas e muitos deles não tiveram nenhuma formação pedagógica em seus cursos de graduação. Por este motivo e por terem a concepção pessoal de que não precisam aprender aquilo que "já sabem: ensinar", oferecem resistências quando, por exemplo, tornam-se alunos de um programa de pós-graduação e se defrontam com disciplinas pedagógicas.

O contexto da educação, do ponto de vista do profissional liberal e da ótica do pesquisador (que julgam irrelevante preocupar-se com o ensino), se apresenta da seguinte forma: se por um lado, o profissional liberal considera que o seu curso de Bacharelado e mais a experiência adquirida na profissão, no mundo do mercado de trabalho, são condições suficientes para que possa ensinar, por outro lado o pesquisador, de modo geral, considera que o Bacharelado, a desenvoltura em pesquisa e a boa produção científica, são mais do que suficientes. Em ambas as situações, o aprendizado pedagógico é tido como desnecessário. Mais uma vez, portanto, o curso de Licenciatura ou as disciplinas pedagógicas de pósgraduação são encarados, pelos próprios professores universitários, como de menor importância.

Há professores universitários que cursaram também a Licenciatura. No entanto, e como destaca a pesquisadora, tiveram o enfoque da sua formação centrado no processo de ensino e aprendizagem da criança e do adolescente e não no aluno adulto. Masetto tem enfatizado, nos seus vários trabalhos, a ocorrência dessa lacuna. Este foi, aliás, um dos aspectos apontados por um dos professores da minha pesquisa, que afirmou ter aprendido "psicologia do adulto por conta própria, através de livros e de observações, a fim de poder dar aula para alunos de universidade" (dados de entrevista).

Pressupõe-se que o profissional liberal tenha sido formado para lidar com adultos, embora num contexto diferente, já que sua destinação inicial não era a docência. Supõe-se, ainda, que o "profissional liberal-professor" (denominação dada pela autora), pelo fato de exercer ambas as profissões, esteja, por essa condição, mais próximo da realidade do trabalho e mais apto a possibilitar uma ponte real entre a teoria e a prática. Da mesma forma, pressupor-se-ia que o profissional professorpesquisador estaria plenamente preparado para efetivar esta almejada ponte como meio e meta de sua atuação. Parece, no entanto, que para um, a prática "é o que conta”, e para o outro a teoria é o ponto de honra. 
Como se "forma" um professor para a docência de $3^{0}$ grau, é um dos questionamentos de Vasconcelos, que o embasa com constatações legais ${ }^{59}$ de que o ingresso no magistério superior e a promoção na carreira se fazem, apenas, a partir da titulação e da produção científica.

Para a pesquisadora, "a questão do comprometimento com os temas educacionais num sentido muito mais amplo do que a simples transmissão de conhecimentos ou experiências profissionais, $e$ as questões da Educação, mesmo as mais complexas, não podem continuar sendo consideradas como "problemas exclusivos de pedagogos", mas sim de todo aquele que, ainda que em tempo parcial, se dedique ao magistério" (Vasconcelos, 1994, p.9).

Neste sentido, propôs-se: "compreender o papel do profissional liberaldocente, sua influência e importância no processo educacional das instituições de ensino nas quais trabalha, e elaborar a sugestão de um projeto de capacitação pedagógica voltado para a reflexão, por parte desses docentes, de sua prática educativa, visando torná-la mais consciente, comprometida e, consequentemente, mais eficaz" (p.11).

Nas colocações de Vasconcelos, a reflexão dessa prática, tendo em vista a capacitação competente do docente de $3^{\circ}$ grau, deve levar em conta fatores do processo de ensino e de aprendizagem, que a pesquisadora chamou de Aspectos da Formação: Técnico-Científica; Prática; Política; Pedagógica.

A Didática e a formação do professor abrangem duas dimensões, segundo Libâneo (1991, p.27): a Formação Teórico-Científica, que inclui a formação acadêmica específica e a pedagógica; a Formação Técnico-Prática, que visa à preparação profissional para a docência, incluindo as metodologias específicas e a didática.

${ }^{59}$ Entre as legislações que apresenta, está a que reestrutura o ensino superior no Brasil, a Lei $\mathrm{n}^{\mathrm{o}}$

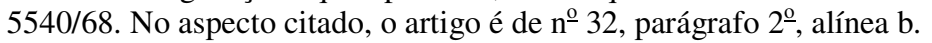


Para Vasconcelos, a formação técnico-científica refere-se ao domínio técnico do conteúdo a ser ensinado. A formação prática significa o conhecimento que o professor deve ter da prática profissional para a qual seus alunos estão sendo formados. A formação política envolve, no compromisso com a tarefa de educar, a preocupação com as questões sociais mais amplas. Finalmente, a formação pedagógica refere-se ao fazer docente "construído no cotidiano, em sala de aula, de modo não ocasional e sim metodologicamente desenhado". "Definitivamente é a competência pedagógica o diferencial de qualidade do professor" (p.47 e 48).

As respostas dos professores-profissionais liberais não foram concordantes com esta última característica. "Muitos consideram que o "dom" é tudo (...). Formação pedagógica soa como pura perda de tempo e nem mesmo há uma compreensão real do que significa, em sentido amplo, o termo 'formação para o magistério' ”' (p.86).

A pesquisadora identificou que a maioria dos respondentes: não se intitula professor; encara o magistério como atividade secundária; considera os salários muito baixos e, gosta de lecionar, mas não pensa em abrir mão de suas profissões.

Concluiu, então, que o profissional liberal-docente é "elemento contributivo para a formação atualizada dos futuros profissionais que a universidade lança no mercado de trabalho, no entanto, é pouco envolvido com o efetivo desenvolvimento da sua função de professor ...” (p.112).

Behrens (1995) também realizou sua pesquisa com profissionais liberais, além de professores universitários, alunos do programa de pós-graduação.

Impôs-se, como continuidade do que faz "desde o início da carreira”, a pesquisa da prática pedagógica dos professores universitários, agora apresentando as perspectivas e os desafios que se colocam, tendo em vista o novo século.

Seu trabalho dirigiu-se para "o novo paradigma" cujas características são: "a questão da informação, a produção do saber e a construção do conhecimento", que a "revolução tecnológica, a informática e a robótica", contribuíram para tornar o atual $3^{-0}$ grau "em descompasso com os pressupostos básicos para o ensino que atenda às necessidades para o próximo milênio" (p.10). 
Os professores com os quais a pesquisadora interagiu, buscam "uma instrumentalização na competência política e técnica para exercerem o magistério (...) e desejam conviver com um referencial da Educação” (p.8).

A realidade encontrada por Behrens difere daquela de Vasconcelos - apresentada em páginas anteriores - que em seus achados se permitiu afirmar que para muitos profissionais liberais-docentes, a formação pedagógica "soa como pura perda de tempo" e que eles não mencionam a dimensão política.

No presente caso, os professores "repudiam a ação docente reprodutivista e querem encontrar novos e coletivos caminhos para formar profissionais competentes e cidadãos conscientes" (p.8).

Afirmei em páginas anteriores - e reafirmo - que a busca de caminhos coletivos em que as experiências sejam socializadas e compartilhadas, realmente é uma atitude para a qual os docentes universitários deveriam passar a convergir sua atuação, que tem sido solitária e individualista.

Uma realização coletiva supõe desde o planejamento até a consecução das leituras, reflexões, discussões e produção escrita, feitas no trabalho por vezes individual e por vezes em grupo, que é coletivizado para que os resultados sejam apropriados pelo conjunto dos profissionais/autores envolvidos.

Supõe ainda, as ações efetivas que são avaliadas pelo próprio grupo num trabalho de cooperação e socialização das experiências, em situações não apenas experimentais, mas também como procedimentos incorporados tanto no ensino de pós-graduação (como no presente caso), como também na graduação, que é onde os professores sentem mais dificuldade na implementação de alternativas metodológicas diferenciadas.

Neste sentido significaria por em prática, na universidade, o comportamento de parceria entre docentes da Licenciatura e do Bacharelado, em benefício dos alunos que serão professores de $1^{\circ}, 2^{\underline{o}}$ ou $3^{o}$ graus, e que por sua vez teriam maior chance de aprender a trabalhar cooperativa e coletivamente, por meio da vivência com professores cooperadores, durante sua formação.

O problema investigado foi: 
"Como o professor redimensiona a sua prática pedagógica a partir da reflexão sobre a ação, realizada individual e coletivamente ao longo de uma situação formal de ensino e através da partilha da sua experiência vivenciada no grupo de professores?" (Behrens, 1995, p.16).

Para tanto, realizou a pesquisa teórica e a prática. $\mathrm{Na}$ primeira, analisou obras, pesquisas, realizações, formulações e indagações de autores: - preocupados com a ação docente de professores diferenciados; - interessados em destacar uma visão de modernidade para a educação; - envolvidos com a proposição de uma abordagem crítico-reflexiva.

Os autores selecionados embasaram a análise feita pela pesquisadora, da prática pedagógica do professor em relação: a si mesmo, ao aluno, à universidade, à sociedade, ao ensino, ao seu papel, à metodologia, (nesse último aspecto quanto ao aprender a aprender do professor e do aluno e à metodologia do aprender a aprender).

A parte empírica foi vivenciada com os docentes universitários nas práticas pedagógicas por eles efetivadas, no "desafio coletivo de encontrar caminhos que apontem para a inovação” (p.42).

Esses caminhos, nas etapas que aconteceram durante um semestre, se referiram: $1^{\underline{a}}$ fase - à “discussão reflexiva das tendências pedagógicas” (tradicional, escola nova, tecnicista, progressista); $2^{\mathrm{a}}$ fase - à "leitura e discussão reflexiva e crítica" dos textos selecionados: $3^{\mathrm{a}}$ fase - à "construção de textos" próprios, sobre a temática: "a prática pedagógica que eu tinha, a prática pedagógica que tenho e a prática pedagógica que gostaria de ter"; $4^{\mathrm{a}}$ fase - implicava em entrevistar os professores para que falassem dos problemas da realidade e levantassem "os fatores que reforçaram o redimensionamento da prática pedagógica, os que impediram a sua reconstrução e as possíveis alternativas encontradas para a renovação docente" (p. 48-52 passim).

A análise foi também feita em blocos: $1^{\underline{0}}$ - se a reflexão crítica coletiva interferiu na alteração da prática pedagógica; $2^{\underline{0}}$ - registro das transformações de cada um em relação ao professor como pessoa e como profissional; ao aluno; à universidade, e à sociedade; $3^{0}$ - os fatores que interferem para impedir ou reforçar o professor para que altere sua ação docente, e $4^{\underline{0}}$ - alterações metodológicas.

Das conclusões que apresenta, dirigidas aos professores, aos alunos, às universidades, às políticas públicas e aos programas de 
capacitação docente, destaco algumas daquelas que se referem aos primeiros, apenas.

Segundo Behrens os professores deverão ter uma visão inovadora, holística, ser sensíveis para entender o aluno no seu todo, encarando-os como brilhantes e imaginativos, e "encontrar caminhos metodológicos que ultrapassem a racionalidade positivista e a reprodução do conhecimento e partir em busca de autonomia e criatividade" (p.215216).

A prática pedagógica terá que envolver a competência, a reflexão crítica, ações criativas e estar dirigida para a interdisciplinaridade. "O professor terá que saber ensinar, educando. Saber fazer pesquisa, elaborar e construir projetos de ensino com pesquisa, aliados à proposição de trabalhos coletivos, reflexivos e críticos" (p.223-224).

Conclui, ainda que o professor, "Como profissional do futuro, espera-se como principal atividade o aprender, pois para as tarefas repetitivas existirão os computadores e os robôs. Para suplantar a problemática da reflexão, os docentes deverão buscar metodologias que empreendam imaginação, criatividade e inovação" (Behrens, 1995, p.224).

Nesse sentido, segundo Behrens, o professor deverá capacitar-se para utilizar os recursos da informática e da multimídia, as conexões às informações mundiais através de redes de computadores integrados à rede telefônica, não deixando de instrumentalizar "seus alunos para esta via de acesso à informação e à produção de conhecimento" (p.225-226).

"Do professor, espera-se um ensino com pesquisa, o aprender a aprender, a utilização dos recursos de última geração, a reflexão dialógica e crítica em busca da produção do conhecimento competente e significativo" (Behrens, 1995, p.226).

Com as proposições que apresentou - resumidamente acima relatadas - a autora

"acredita que o docente passe a ser visto em sua prática pedagógica como agente crítico, competente e provocador da qualidade e da relevância dos 
conhecimentos produzidos no ensino superior e venha a readquirir o seu papel como profissional respeitado pela sociedade” (p. 234).

As considerações de Behrens são ousadas. Ressalvo, no entanto, que a maioria dos professores não domina aquilo que Dowbor chama de "novos espaços do conhecimento"60, os quais não se confundem com o conjunto de informações disponíveis na rede mundial de computadores. Concordo quanto a se colocar os benefícios tecnológicos a serviço do ensino, sem perder de vista, entretanto, que são recursos adicionais facilitadores do processo educativo, não devendo ser colocados como as finalidades desse mesmo processo. Além disso, dada a ênfase do seu discurso, as considerações assumem um caráter imperativo, como se esses recursos, por si, fossem garantia de uma prática docente mais eficaz e de reconquista da respeitabilidade social.

A meu ver, estas propostas devem ser vistas com olhos da realidade, equilibrando-as com outras ênfases que estão sendo dadas por estudiosos da prática docente, cujos caminhos buscados se inserem numa postura reflexiva e identificada com uma inserção social mais ampla quando constroem sua prática.

Foresti (1996) apresenta, sobre a prática docente na universidade, além da contribuição teórica relevante, um protótipo de um sistema hipermídia de Educação à distância, tendo em vista a formação pedagógica continuada.

Tal protótipo desempenha a função de subsidiar teoricamente os docentes universitários nas suas reflexões pessoais e na construção de seus próprios caminhos, quanto à produção do conhecimento científico, aperfeiçoando o processo de ensino que ocorre nas salas de aula do $3^{-}$grau e articulando teoria e prática.

A pesquisadora adotou "como pressuposto a metáfora do conhecimento como rede de significações" (ou a ideia de caminho em construção), a fim de desenvolver o projeto, cujos mediadores foram o computador e a Telemática (p.4).

A proposta possibilita a continuidade pelo próprio docente usuário do sistema, numa atitude de interação, "criando novas teias $e$

${ }^{60}$ Dowbor, L. - Espaços do Conhecimento. Palestra proferida na Conferência Internacional de Educação do Futuro. São Paulo: 4 a 8/out./93. 
construindo novos nós de informação", no sentido de ampliar e aperfeiçoar sua própria formação, "aplicando a tecnologia dentro do conteúdo de sua especialidade” (p.97).

As informações levantadas na literatura a respeito da prática docente na universidade foram inseridas no sistema em três grandes "pontos-âncoras". Eles serão aqui descritos na forma como foram apresentados pela autora:

“- Caminhos e caminhantes - A preocupação foi inserir nós de conteúdo diretamente relacionados à preocupação imediata do professor com o cotidiano da sala de aula na universidade, incluindo problemas comuns e experiências bem sucedidas e já explicitando alguns fundamentos teóricos da prática, articulando-os ao contexto mais amplo do ensino superior e à existência de paradigmas.

- Os caminhos da universidade - A questão do ensino superior é focalizada a partir de nós informacionais sobre a história da universidade e sobre a sua função social, explicitando a questão dos paradigmas que têm norteado as atividades essenciais da Academia e sua repercussão nas propostas curriculares e na própria ação pedagógica do professor universitário.

- Aprendizagem pelos caminhos - contendo nós de informações teóricas mais específicas sobre prática pedagógica e didática no ensino superior, articulados com conteúdos veiculados nos outros dois nósâncoras do sistema" (Foresti, 1996, p.107).

Os pontos âncoras podem ser acessados independentemente, mas "estão, na verdade, articulados formando uma rede de informações não lineares” (p.107). Na proposta, a interatividade é possibilitada por outros dois pontos-âncoras que foram incluídos: Novos Caminhos, onde os usuários poderão construir outros nós relatando suas experiências e informações, e Biblioteca do Professor, contendo nós de referências bibliográficas que "poderão vir a ser completadas pelos usuários do sistema” (p.108).

O ponto-âncora Aprendizagem pelos Caminhos, não prototipado, mas apresentado em sinopses, coloca os pontos teóricos da prática docente considerados mais relevantes pela autora. Merecem destaque os seguintes nós-informacionais: educação continuada, relação 
professor-aluno, aprendizagem de adultos, metodologia, procedimentos de ensino, ação pedagógica, planejamento e avaliação (p. 157-164).

Lima (1995) investigou "A memória educativa no projeto de formação de professores do ensino superior: o fazer é, sobretudo, criação", e concluiu que a formação do professor

"começa desde quando ele ingressa na escola, nas primeiras séries do $1^{o}$ grau, porque, desde então, já inicia a construção de saberes escolares necessários à prática pedagógica”. "O saber que o professor constrói na historicidade de seu processo formador é um saber racional, ético e estético". (extratos do resumo).

Valeu-se da metodologia da análise crítica da memória educativa - denominação criada pela autora - e designativa de "instrumento que pudesse gerar uma análise crítica da prática pedagógica e uma alternativa de reconstrução da referida prática” (p.73).

Para ela, "a memória educativa - lembranças que os professores-alunos trazem de sua escolaridade - é um dos saberes pedagógicos necessários à formação do professor” (p.67).

Neste sentido, as lembranças dos sujeitos foram coletivizadas e analisadas em seus pontos comuns e divergentes. A finalidade básica foi

"redescobrir o conteúdo educativo vivido na história de cada aluno, interpretar esse conteúdo, compreendendo as relações sociais que o permeiam e, ao mesmo tempo, tentar construir um novo projeto de Metodologia para o Ensino Superior, considerando-se os elementos da história, os conflitos e contradições, identificados na memória educativa, como mediadores de uma nova postura em face do trabalho docente no $3^{\underline{o}}$ grau” ( Lima, 1995, p.12).

Assim sendo, o professor:

"durante toda a sua escolaridade se vê exposto a diferentes tipos de professores: conservadores, críticos e transformadores. E, assim, ele vai fazendo a sua avaliação e selecionando os saberes didáticos que, posteriormente (...) desenvolverá na sala de aula 


$$
\begin{aligned}
& \text { ou usará nas diferentes situações de prática } \\
& \text { pedagógica que vivenciar (...) ”( } 1.84-85) .
\end{aligned}
$$

Pela linha de raciocínio de Lima, na seleção que faz dos seus saberes didáticos, quase todos os professores reportam-se a um saber ditado pela escola tradicional, aquela que é transmissora do conhecimento e cujo professor é o centro, formando o aluno para a obediência, disciplina e rigor teórico. Decorre, daí, que o professor "plasmado" na escola tradicional não apaga essa característica da sua formação e ela vem à tona para uns mais, para outros menos - embora todos tenham a intenção da prática participativa. É forte, portanto, o modelo de escola desde o primeiro ano da escolaridade do indivíduo. Durante o curso de formação profissional é relevante a prática dos bons ou maus professores.

A autora reafirma que o projeto de formação do professor não é específico dos cursos de formação ou de pós-graduação, mas acontece "em todos os momentos de sua história de vida: como estudante, como professor e a partir dos alunos que recebe em suas salas de aula” (p.115). Decorre também das relações na família e nos variados grupos sociais dos quais a pessoa faz parte desde o nascimento.

Não é feito referência às dimensões preconizadas por Nóvoa (1992a), mas parece, por esta assertiva, podermos extrapolar para o desenvolvimento pessoal e profissional direcionando a "construção do saber didático" (Lima, 1995, p.115).

A prática apresenta dificuldades no início do magistério, segundo os professores pesquisados por Lima. Falam de suas inseguranças, limitações, idealizações e expectativas (características que formaram perguntas que fiz aos professores do meu estudo).

Os focos: experiência, exemplo pessoal, modelos de professores que teve, aprendizagem contínua, fatores de modificação e reflexões pessoais, que privilegiei no meu trabalho, aparecem ora explícita ora implicitamente na investigação de Lima, que, na verdade, os resume na memória educativa, que "influencia de maneira decisiva a prática" (p.125).

A autora usa o termo "reengenharia" do processo educativo, para significar a busca de se "transformar o cognitivo em suas 
múltiplas formas de expressão artística” (p.131)61. Estão presentes, portanto, o estético e o ético. É o momento em que os alunos-professores estudam os textos individualmente, realizam discussão em grupo, produzem seus textos, problematizam a própria prática trazendo a realidade para a discussão iluminada pela teoria e, finalmente transformam todo esse "conhecimento em um saber artístico, isto é, cada grupo de alunos constrói coletivamente uma forma estética" (são músicas, poemas, representações teatrais, jograis, desenhos etc, p.138).

didático.

É uma forma coletiva e socializada de construção do saber

Lima questiona "quais as razões do bloqueio da dimensão artística como saber escolar" e sugere que sejam pesquisadas.

A "nova epistemologia da prática [é] entendida como um processo artístico de reflexão e ensaio”, ... [em que] "as atenções voltam-se para uma concepção mais artística da profissão docente e para modelos de formação que preparem os professores para o exercício desta arte nas situações divergentes da prática”. (Pérez Gómez, in: Nóvoa, 1992a, p.109).

Esta colocação de Pérez Gómez, ao explicitar os modelos da "racionalidade técnica e racionalidade prática", chamam a atenção para o mesmo ponto questionado por Lima. Também para a pesquisadora, no trabalho da formação do professor o fazer é criação e, portanto, a criatividade artística deve estar presente.

Na pesquisa de Behrens (1995) deve-se buscar, nos meios educacionais, a criação, a produção e não mais a reprodução, seguindo a linha de Demo (1992) que centraliza a criação e a produção na questão da pesquisa. Lima (1995) propõe a criação como consequência de um saber e fazer, que devem ser conscientes, contemplando com igualdade o racional, o estético e o ético.

Godoy (1989, 1992), investigou o ambiente de ensino (ou da sala de aula) preferido pelo aluno universitário, sob a ótica do próprio aluno.

\footnotetext{
${ }^{61}$ Reengenharia é também uma técnica que se apoiando em softwares, possibilita a substituição de um grande número de trabalhadores, eliminando empregos, reduzindo os salários e, claro, aumentando o lucro empresarial. Veja-se, por exemplo, Head, S. Nova economia expõe sua face mais cruel. Jornal O Estado de São Paulo, Caderno 2, ano IX, nº 3381, 12/05/96.
} 
Adotando a posição de que o aluno é a razão central do ensino, a autora considera relevante sua opinião quanto aos vários aspectos presentes no processo de aprendizagem, a fim de que professores e administradores escolares tenham condições melhores de atuar e tomar decisões.

A pesquisadora selecionou alguns desses aspectos para estudo e utilizou um instrumento especialmente construído para a pesquisa, denominado Inventário sobre Preferência do Ensino (IPE). Ele contém asserções às quais o aluno responde se concorda, é indiferente ou discorda. Há, portanto um direcionamento implícito.

Nos resultados, obteve quinze fatores. "Em princípio, cada fator deve representar uma dimensão (aspecto) do ensino em sala de aula” (Godoy, 1992, p.72).

Considero oportuno mencionar alguns fatores e as análises apresentadas porque se referem ao ensino, aos professores, à aprendizagem, aos alunos, enfim à sala de aula do $3^{-0}$ grau.

O fator mais indicado foi Técnicas de Ensino, demonstrando que o aluno de $3^{-}$grau valoriza esse aspecto. Sua preferência acentuada foi por aulas expositivas com trabalhos individuais e/ou em grupo. Neste último caso, querem situações estruturadas e textos de apoio.

A pesquisadora interpretou as preferências como sendo essas as formas que ocorrem mais comumente na vivência do aluno e que "refletem a pouca diversidade de opções dos professores de $3^{o}$ grau" (p.83). Alerta, no entanto, que os alunos concordam com a necessária diversificação de técnicas e aconselha "um rol mais amplo de estratégias de aula” (p.83).

Resumo do conteúdo da aula, no início ou no fechamento, e textos com vocabulário de fácil compreensão foram a preferência no fator Material de Apoio. Nas instituições de caráter privado, os "professores que ditam a matéria”, ou seja, apresentam o conteúdo falando pausadamente para que o aluno consiga anotar, facilita o estudo, posteriormente, para aqueles que trabalham e estudam, segundo os dados obtidos por Godoy (1992, p.83).

Os fatores Perguntas e Atenção aos Alunos indicaram alta preferência quanto aos professores que durante a explicação fazem 
perguntas e esclarecem dúvidas durante a exposição, respectivamente. O aluno quer, portanto, participar e ser envolvido no processo instrucional. São dimensões de ordem afetiva e, ao contrário do que supõem alguns docentes do $3^{\underline{0}}$ grau - inclusive um dos sujeitos do meu estudo - o aluno adulto ressente-se pelo tratamento excessivamente técnico-formal, frio e distanciado, que muitos imprimem à aula. No segundo fator mais apontado, o Ambiente Sócio-Emocional - e ainda para reforçar - os alunos manifestaram alta preferência por clima de diálogo para conversas de ordem pessoal e também informal.

Acrescentem-se os fatores referentes às características pessoais dos professores, ou seja: entusiasmo, elogio-encorajamento e seriedade-humor, que disparadamente, receberam pontuações quanto aos professores que são entusiasmados com o trabalho docente, elogiam e encorajam os alunos, e usam de humor durante as aulas. É a interação professor-aluno.

No estudo sobre "os sentimentos dos professores nos diferentes graus de ensino", Mosquera (1976) pronunciou-se sobre a interação no $3^{-0}$ grau:

"a preocupação com as variáveis nas diferenças individuais é um passo bastante certeiro para obter resultados benéficos no processo ensinoaprendizagem. Salienta-se que na medida em que uma sala de aula não é apenas vista como uma massa há possibilidades de compreender melhor as expectativas e interesses que inevitavelmente acontecem no ambiente acadêmico" (Mosquera, 1976, p.157)

No fator Avaliação, os alunos preferem professores que atribuem suas notas às provas individuais e à participação nos trabalhos realizados em sala de aula, ou seja, têm preferência por docentes que não se baseiam em um só procedimento de avaliação.

No fator Organização do Conteúdo, os alunos preferem professores que iniciam a aula com um resumo do que será explicado, que fazem recapitulação de matéria anterior e que fazem uma programação diária das atividades do curso. Isto indica claramente que sua preferência é por ambientes de sala de aula bastante estruturados.

Godoy (1992) alerta para o fato de que, nos anos oitenta se estava trabalhando: 
"com um grande número de alunos que precisam receber orientação e acompanhamento para que consigam maior êxito acadêmico. Cumpre criar mecanismos que ajudem esses estudantes no processo de superação de suas dificuldades” (p.86).

Quais serão os fatores mais influentes na sala de aula dos anos noventa e da virada do século, sob a ótica do aluno, utilizando-se, agora, procedimentos qualitativos de pesquisa?

Foi possível localizar publicações feitas no formato de artigos e comunicações em eventos científicos, a partir de 1990, sobre as questões da formação inicial e continuada, influência ou não da formação pedagógica, experiências, relatos e vivências, pressupostos filosóficos e curriculares, redefinição do trabalho docente, estado da arte sobre formação de professores, caracterizando que realmente existe a preocupação com a docência no ensino superior, seja ela direcionada à Licenciatura ou ao Bacharelado, tendo em vista que o licenciado atuará no magistério de $1^{\underline{0}} \mathrm{e}$ $2^{\underline{0}}$ graus e o bacharel poderá vir a ser professor universitário.

Algumas dessas publicações, selecionadas entre aquelas com as quais tive contato, têm a ver mais, ou menos, com meu trabalho de compreensão da prática docente no $3^{0}$ grau. Destaco Alonso (1994), Cunha \& Fernandes (1994), Freitas de Lima (1995), Gatti (1992), Perdigão, Bueno $\&$ Tancredi (1992) e Severino (1991).

Os aspectos abordados formam as concepções aqui disponíveis sobre a problemática anunciada. O eixo unificador é a formação, que centraliza as colocações desses autores. Como consequência, todos eles tratam da prática docente (o ensino, o professor, os elementos da reprodução existente e da necessária elaboração própria). Alonso, Perdigão e Freitas de Lima, abordam, ainda, as mudanças significativas que estão ocorrendo e que provocam alterações no conhecimento e nas suas formas de apropriação, possibilitadas pela tecnologia, nos dias atuais. As questões curriculares também são explicitadas. A dimensão política e social comparece em todos eles, sendo, inclusive, o papel da universidade e as indicações de um projeto institucional, apresentados por Cunha e Gatti.

Considero oportuno e necessário explorar, um pouco, algumas das questões, discussões e conclusões oferecidas. 
Alonso (1994, p.1-3) caracteriza que a tecnologia moderna permite que a informação atualizada seja "obtida de forma prazerosa, interessante e didática (...) em confronto com o ensino voltado para a reprodução (...) sem elaboração própria ou apelo à inteligência $e$ criatividade", que ocorre nas escolas, com a aquiescência da acomodação e passividade de alunos, professores e administradores. Enfatiza a necessária união do administrativo e pedagógico, numa "forte articulação entre "concepção" e "execução", tanto em nível do dia-a-dia, quanto da formulação curricular”.

Para tanto, é necessário um processo de transformação que passa necessariamente pela superação de barreiras na busca da profissionalização do magistério. Uma é a concepção e atuação do professor que tem uma

"forma de agir muito mais condizente com o comportamento do "funcionário burocrático" nos moldes weberianos possível do que com o do profissional comprometido com os resultados efetivos de seu trabalho e as consequências no social" (p.4).

Aponta como condições essenciais para aqueles que trabalham com a formação e capacitação docente, que se conheça o pensamento do professor, as suas posições frente ao processo de ensino como realidade concreta e as bases da sua atuação em sala, como suportes para desenvolver sua capacidade de análise e reflexão.

No meu estudo, o pensamento do professor é compreendido (guardadas as limitações dos modos subjetivos de captação e interpretação de pesquisador e pesquisado) por meio das entrevistas, e as bases de sua atuação em sala poderão ser entendidas por meio da observação das aulas, a fim de clarificar e levantar parâmetros para futuras reflexividades conjuntas com consequente tomada de consciência sobre a prática docente tanto desses como dos professores de áreas afins. Da mesma forma, não foi minha preocupação a construção dessa prática e nem as indicações sobre quem é o bom professor.

Cunha \& Fernandes (1994, p.7), re-apresentam pontos relevantes da análise de Cunha sobre o "bom" professor universitário. O aspecto apontado como "o mais significativo" foi que os alunos aceitam como bons os professores que "ainda trabalham na perspectiva da reprodução do conhecimento", ou seja, "desenvolvem grande número de habilidades de ensino (...) e apresentam muitas qualidades humanas $e$ afetivas". No entanto, a autora alerta quanto ao devido cuidado de se tomar 
"ipsis litteris" tal aceitação, irrelevando-se que "não conhecem procedimentos sobre como fazer o aluno chegar ao próprio mapeamento da sua aprendizagem e (...) pouco estimulam o aluno a fazer suas próprias pesquisas". Outras indicações foram que a maior influência para a atuação docente vem da história como aluno e dos modelos de professores que teve, e que a própria prática é a "grande inspiração para a mudança e para o saber que se constrói a partir daí”.

As possíveis considerações apontam que os resultados são “estímulos para tentar avançar a prática e a teoria pedagógica (...)”, a identificação do "ciclo de reprodução" é fundamental, e, principalmente, que a prática, a experiência e o fazer/refletir são decisivos para delinear o desempenho docente (p.8).

As autoras avançam propondo a "intencionalidade" da universidade no sentido de reconstrução do seu projeto pedagógico na "perspectiva da produção do conhecimento", que tem no "ensino com pesquisa" a pedra de toque (p. 3-4. O grifo é meu).

Cinco teses propostas para "iluminar a compreensão teórica da formação continuada de professores participantes do projeto de produção do conhecimento" - que está sendo efetivado por Cunha \& Fernandes na universidade em que trabalham - são apresentadas no sentido da sistematização do empírico. São elas: a formação contínua deve girar em torno de projetos de ação e resolução de problemas muito mais do que sobre conteúdos acadêmicos; deve incentivar troca de experiências, partilha mútua de saberes e criação de redes coletivas de trabalho docente; deve alicerçar-se numa reflexão na prática sobre a prática; deve incentivar a participação de todas as fases dos programas de formação contínua; deve capitalizar experiências inovadoras e redes de trabalho existentes e investir na sua transformação qualitativa (p. 15-16).

Gatti (1992) refere-se à formação inicial e continuada como "faces de uma mesma problemática", que não tem sido assumida pela universidade (p.70). Também são passíveis da não-valorização, pelos próprios docentes, a experiência, o conhecimento alcançado pela prática e o trabalho de parceria. Denuncia a ausência de um "lastro institucional $e$ filosófico comum quando se trata de formar o professor", ao contrário do que ocorre na formação de profissionais de outras áreas, identificando "uma crise de finalidade formativa" (p.72).

Para Severino (1991, p.33-35), essa formação tem uma tridimensionalidade dada por: domínio dos conteúdos que tem a ver com a 
cultura científica em geral, mediando o "processo mais amplo de conscientização"; dimensão das relações situacionais que permite a integração numa sociedade historicamente contextualizada; domínio de habilidades didáticas, "esfera dos instrumentos técnicos e metodológicos", para o desempenho docente sobre bases não-espontaneístas.

As concepções e vivências dos professores universitários diferem pelo fato de terem ou não, tido formação pedagógica no seu curso de graduação? Freitas de Lima (1995) estudou relatos verbais de dezoito docentes do $3^{\mathrm{o}}$ grau, com e sem formação pedagógica, constituindo quatro subgrupos:

1- Professores com formação pedagógica que lecionam Didática, Metodologia e Prática de Ensino;

2- Professores com formação pedagógica que lecionam Fundamentos da Educação e Habilitações do Curso de Pedagogia;

3- Professores com formação pedagógica que lecionam disciplinas da área tecnológica;

4- Professores sem formação pedagógica que lecionam disciplinas da área tecnológica.

Os resultados não permitiram aceitar a hipótese inicial de que professores sem formação pedagógica têm a prática de transmissão e reprodução, enquanto que aqueles com formação pedagógica preocupam-se com a elaboração própria e o desenvolvimento do pensamento reflexivo (p.5).

O subgrupo 1 verbalizou concepções e vivências de inspiração cognitivista, que prioriza as atividades do aluno, o desenvolvimento da inteligência e a construção do conhecimento.

O subgrupo 2, "mesmo tendo formação pedagógica e atuando diretamente nos cursos de formação de professores, se assemelhou ao subgrupo 4 que não tem formação pedagógica e são professores da área tecnológica” (p.8).

No subgrupo 3, "houve certa identificação com os relatos do subgrupo 1" quanto ao conceito de ensino como processo, planejamento com a participação do aluno, avaliação contínua e professor como orientador de aprendizado, embora suas aulas sejam basicamente expositivas (p. 7-8). 
O subgrupo 4 identificou-se com "o modelo de ensino do tipo tradicional" (p.6).

Importante a conclusão de Freitas de Lima (1995, p.10) quanto à necessidade de "dados oriundos da observação direta da prática pedagógica dos professores envolvidos". A pesquisadora sugeriu que sejam realizadas pesquisas neste sentido.

Concluiu, também, por se "refletir acerca da própria formação pedagógica adquirida através de cursos formais (graduação ou pós-graduação), já que o estudo a considerou como critério" (p.10).

Sabemos que é preciso continuar investigando sobre o $3^{0}$ grau. Sabemos também que acreditamos na formação pedagógica. Precisamos, então, investigar e partilhar experiências sobre qual formação pedagógica faria a diferença. Acreditamos no processo de formação que tem um começo deflagrado no curso inicial e que, por ser um processo, deve continuar por meio de uma atuação diferenciada, reflexiva, crítica e partilhada (de preferência com grupos voltados para alternativas mais ousadas na formação continuada).

A prática docente no $3^{\underline{0}}$ grau é um terreno a investigar. Professores das Faculdades de Educação já manifestaram não saber qual foi o processo de ensino e aprendizagem dos alunos que recebem. Muitas vezes ignoram como atuar/intervir durante o período de tempo em que permanecem com eles, embora acreditem que a metodologia esteja vinculada à construção social da disciplina.

Este aspecto é ressaltado por Perdigão, Bueno \& Tancredi (1992) na proposta de que

"licenciados e bacharéis tenham uma formação básica semelhante, derivada da interseção dos conteúdos de formação - desenvolvidos em algumas disciplinas da área de formação humanística $e$ pedagógica e em um conjunto de disciplinas da área específica de formação - que definem o corpo de conhecimentos/habilidades básicos comuns a esses dois tipos de profissionais. A intenção é que o Bacharelado forme o pesquisador-professor e que a Licenciatura forme o professor-pesquisador" (Perdigão, Bueno \& Tancredi, 1992, p.6) 
As considerações teóricas que serão apresentadas nesse momento do trabalho, não pautam pela verificação sobre se as habilidades, comportamentos e atitudes dos professores estudados conduziram-se, ou não, pelo conjunto de ideias que vou tentar tecer e que é próprio e foi construído pelos autores que o formularam e o defendem.

Um dos motivos dessa não-confrontação é que este estudo não é avaliativo. Também não é sobre professores individualmente. Compreende a prática docente no $3^{\underline{0}}$ grau.

Neste sentido (em segundo lugar), no momento atual e ao contrário do como se conduziam as pesquisas nos anos 70 e 80 - não se privilegia um instrumento ou modelo (que, é claro, tem uma fundamentação teórica que lhe dá corpo e o sustenta), com a finalidade de enquadrar ou não os sujeitos e, consequentemente, analisá-los segundo os pressupostos daquele quadro de referências, classificando, então, sua prática e designando-lhe um bom ou mau lugar. Ao contrário, parte-se do seu fazer concreto, das suas experiências/vivências e das suas elaborações explicativas para compreendê-lo dentro das suas concepções e construções, tentando imergir no seu fazer docente e emergir captando os significados que ele atribui à sua prática.

No entanto, considerando-se que o ato reflexivo é caraterística humana, todo profissional que se propõe ser competente precisa refletir sobre aquilo que faz a fim de que não seja um executor mecânico e rotineiro.

A reflexão que se realiza, evidentemente não é fruto do acaso. Somos circunscritos e influenciados por valores, ideais, temporalidade, crenças, reflexões, enfim formulações da nossa cultura, na evolução que realizamos em nós como um todo, incluindo, sem dúvida, nosso "eu" profissional, pelo qual somos responsáveis diretos.

O fator primordial é o professor e de nada adianta fazer determinadas imposições, mesmo que teóricas, se não se coloca o como esse profissional atua e desenvolve sua prática. O que os autores, que se inserem naquilo que tem sido denominado de "estudos sobre o pensamento do professor", estão sugerindo é o caminho inverso, ou seja, conhecer o professor e a partir do conhecimento de sua atuação, fazer a ponte com a teoria.

Acredito que hoje estamos vivendo uma fase iniciada em 1984, com "O professor é uma pessoa", de Ada Abraham, como lembrou 
Nóvoa. Não só se passou a investigar o professor em processo profissional, como também a pessoa deste professor. Em 1991, Nias afirmou que "o professor é a pessoa, e uma parte importante da pessoa é o professor" (in: Nóvoa, 1992a, p.15).

O horizonte que se abre, com a perspectiva do desenvolvimento pessoal, profissional e organizacional (Nóvoa, 1992a), não pode ser obscurecido e nem interrompido, embora careça de estudos. Descortiná-lo supõe levar em conta fatores sobre os quais não temos clareza absoluta, exigindo, então, questionamento e reflexão sobre os pontos que parecem ser, neste momento, elementos preciosos.

Um deles é a experiência. Essa condição foi entendida como senso comum e, portanto, não científica devido ao (ranço do) positivismo, racionalismo e tecnicismo. À medida que os próprios professores criarem espaços de interação entre eles, as práticas bem sucedidas poderão ser socializadas e poder-se-á resgatar a experiência do professor. $\mathrm{Na}$ universidade, quando o professor vai contar, por exemplo, numa entrevista, algo que ele faz e tem respaldo científico, sente-se à vontade, mas falar de experiências que tiveram bons resultados, em termos de sala de aula, os deixa cautelosos e, muitas vezes, não falam. No momento da observação das aulas percebe-se a lacuna que ficou na verbalização: na aula ele tem iniciativas eficientes da própria experiência e, no entanto, não teve a coragem de falar. Pode ser que não tenha falado porque não tomou consciência. É desejável que tome. A experiência não tem que ser considerada "apenas numa dimensão pedagógica, mas também num quadro conceptual de produção de saberes" (Nóvoa, 1992a, p.25).

O como fazer é dado, também, pela elaboração pessoal das experiências. Durante muito tempo, o professor ficou na dependência de linhas teóricas que deveriam ser dominadas por ele e postas em prática para garantir a eficiência. Muitas vezes, ele até as dominava teoricamente, mas a suposição de que esse domínio não era, efetivamente, transposto para a sala de aula, levou à realização de pesquisas, na década de 80 , sobre se o que os professores postulavam teoricamente era coerente com a sua prática pedagógica (Mizukami, 1983; Pagotto, 1988). A conclusão, entre outras, quanto à presença de coerência interna na prática docente, foi importante. Posteriormente, surgiu a investigação daquilo que se caracteriza como a experiência e o conhecimento prático do professor. Na pesquisa realizada em 1989, Cunha constata que os "bons professores" reconheceram a influência do saber construído na experiência, confirmando que "a prática é um elemento importante na aprendizagem e que a experiência que o 
indivíduo vive é insubstituível no seu significado educativo” (Cunha, 1994, p.160).

Evidentemente, a atuação pedagógica não vai garantir o desenvolvimento profissional, se dela não fizerem parte a análise e a reflexão. Se o professor se vê como mero executor do que foi pré-fixado, poderá iniciar e terminar a carreira exatamente da mesma forma. "Nada o arranha". Essa insensibilidade pode ser o reflexo de uma escolaridade prévia e de um curso de formação que não "mexeram" com ele.

O saber não rotulado academicamente de correto, aquele que não segue as normas, foi sempre desconsiderado. Enquanto saber de categoria profissional, ele não foi investigado. No momento atual, diferentes autores, ligados a diferentes grupos teóricos, estão valorizando o saber do professor partindo do que elabora pessoalmente, com a finalidade de investigar cuidadosamente e verificar se há tendências comuns no processo de formação continuada, se é possível identificar ciclos profissionais, se diferentes professores, de diferentes linhas e países têm apresentado trajetória semelhante, em termos da prática docente e da construção desta prática. É a preocupação com o “formar-se" professor (Nóvoa, 1992a, p.24).

Para Perrenoud (1993)

"Se o professor tem pouco tempo para reflectir no próprio momento da acção, pode, em contrapartida, com a cabeça mais desanuviada, relembrar $e$ debruçar-se sobre os acontecimentos do dia. (...) $E$ possivel que esta releitura da experiência conduza, na maior parte das vezes, a uma confirmação da prática. No entanto, poderia ser factor de mudança, de reorganização de esquemas se existisse, sob uma forma ou outra, um conflito cognitivo, uma contradição entre as decisões tomadas e uma norma, uma teoria ou uma outra experiência” (Perrenoud, 1993, p. 44).

Daí a importância do trabalho em comum e da troca de saberes.

Se, por um lado, a experiência é um fator altamente positivo que deve ser revalorizado na atuação docente, por outro lado encerra o risco do professor não deslumbrar-se mais diante da novidade ou, sequer, percebê-la, fazendo da sua ação uma rotina enfadonha para ele e 
para os alunos. Nesse caso, canalizará, ainda mais, suas atenções para a pesquisa, na busca de sentir-se realizado pessoal e profissionalmente, por vislumbrar nela a possibilidade de ver "coisas novas" e de sentir-se desafiado. A experiência, então, deve ser um apoio para ousadias e não para acomodações.

O ensino não é exclusivamente uma forma de arte e nem pura análise científica. Ele apresenta (deveria apresentar) as duas características. Colocando a questão dessa forma, Woods explora a criatividade, improviso, percepções, empatia, intuição, inovação, experiência e valor. Segundo ele, "o professor sem experiência e sem criatividade fica imobilizado, experimenta um "nó" no pensamento ..." (in: Nóvoa, 1991, p.132-145).

Às vezes, o professor reprime-se porque sente esse "nó". Sua formação pessoal e educacional foi inflexível e ele não consegue mudar, inovar, ou aproveitar as situações que se apresentam repentinamente.

Há professores que têm prática, imaginação e flexibilidade de atitudes e pensamentos, mas sufocam essas condições que seriam enriquecedoras do ato pedagógico, porque aprenderam que ciência é "coisa séria”. Não deixam essas características emergirem porque incorporaram automatismos e acreditam que só se faz ciência com extrema rigidez de comportamento intelectual, emocional e postural. Às vezes, têm traços de pensamento divergente que estão adormecidos pelo processo de ensino que desenvolveu e incentivou o pensamento convergente. "Infelizmente, grande parte da formação do professor parece mais destinada a eliminar a criatividade do que a encorajá-la e a formação contínua é normalmente dirigida para tarefas específicas" (Woods, in: Nóvoa, 1991, p.146).

Outro elemento precioso é a reflexão. "O caráter reflexivo do fazer docente é característica decisiva, porém pouco investigada, ainda que cada vez mais presente no discurso dos educadores brasileiros. O professor bem sucedido é o que reflete sobre sua ação, (re)pensa seus fundamentos, seus sucessos e fracassos e toma isto como base para alterar seu ensino. (...) O professor age (...) não como mero executor de tarefas estabelecidas normativa $e$ acriticamente - como no tecnicismo" (Dias da Silva, 1992, p.15). 
O expoente da corrente cujos pressupostos se baseiam numa perspectiva de ensino como prática reflexiva é Schön. Sua proposta assenta-se na "busca de uma nova epistemologia da prática profissional". Para tal, partiu de três problemas: as competências que os professores devem ajudar a desenvolver; os tipos de conhecimento e de saber-fazer que permitem o desempenho de um trabalho eficaz; a formação mais viável para o desempenho do trabalho docente (in: Nóvoa, 1992a, p.80).

Baseando-se em situações ocorridas entre professores participantes de um projeto, Schön passou a considerar o ensino, a aprendizagem e o conhecimento sob as formas do "saber escolar" e da "atitude de dar razão ao aluno". A primeira, a "noção de saber escolar", ancora-se na transmissão do conhecimento de maneira a reproduzi-lo, não sendo permitida sua reelaboração. É o ensino identificado com a didática tradicional. A segunda é a "reflexão-na-ação" que faz com que o professor procure entender o processo de conhecimento próprio de cada aluno, antes de impor o saber acumulado pelas gerações e que é tido como o correto e exato (p.80-82).

Sua contribuição maior será sobre a reflexão-na-ação, fonte inspiradora da sua proposta de "formar professores como profissionais reflexivos" (p. 77).

O professor reflexivo é aquele que solicita o saber intuitivo do aluno, ouve-o, surpreende-se (é o primeiro momento) pelo que ele faz e para isto não poderá ser um professor que só quer a mecanização e a reprodução. Além disso, ele refletirá (é o segundo) sobre o que o aluno disse ou fez. No terceiro momento, reformula o problema, ao invés de rotular e abandonar o aluno. Finalmente, estabelece nova tarefa, coloca nova questão para testar o que formulou sobre seu modo de pensar. Portanto, a reflexão que o professor faz é uma reflexão-na-ação do aluno primeiramente e não privilegiando a ação dele, professor (p.83).

Se o professor, após a aula, pensar no que aconteceu, podendo posteriormente adotar procedimentos complementares ou até novos em relação ao fato, esse comportamento caracteriza a reflexão sobre a reflexão-na-ação, que é um olhar retrospectivo sobre o que aconteceu, o significado atribuído, o que fez e o que poderá vir a fazer. Supõe um professor suficientemente flexível, atento e que está pronto para estabelecer uma atitude interativa com seus alunos, no sentido de tentar colocar-se no seu lugar e compreender o que se passa. Como afirmou um dos professores do meu estudo: "Você não pode perder a visão de aluno. Não pode perder de vista o que você era antes, o que é ficar surpreso, o como se aprende, 
para não se distanciar e não perder a linguagem de aluno. O conhecimento científico tem que ser concomitante com o conhecimento humano". Considero surpreendente! Vai ao encontro da proposta de Schön de que "faz parte das suas [do professor] incumbências encorajar e dar valor à sua própria confusão” (p.85).

A “confusão" do professor está colocada no sentido de que a resposta tida e dada como verdade pronta e acabada é própria da noção de saber escolar que perpetua e reproduz o conhecimento fazendo com que o outro ( o aluno ) acredite que ela sempre está além e fora dele, criando um ser de dependências e não de autonomia. Na afirmação "a palavra mágica é resposta" (p.86), Schön resume aquilo que tem sido a expectativa de muitos de nós, professores, de que há uma resposta já pronta e ela está sempre fora, cabendo-nos, portanto seguir as regras. Sentimos que outras pessoas as encontraram em primeiro lugar ou as apresentaram de forma mais atraente e elaborada.

"Existe um sentido de segurança em pensar que existe uma resposta, algures, que existe sempre uma resposta a cada situação”. (...) É arriscado tentar algo de novo, é preciso possuir-se autoconfiança, desenvolvida a partir de uma consciência interior $e$ da auto-estima” (apud Schön, in: Nóvoa, 1992a,p.86).

Investir na reflexão e tomada de consciência de nós mesmos e de nossa experiência, e no incentivo aos nossos alunos para que o façam, valorizando seus próprios achados, me parece um caminho mais verdadeiro e significativo. Schön propõe um professor que "se torne mais capaz de reflectir na e sobre a sua prática” (p.88. Grifos do autor).

Ao resgatar a imitação (p.90), que "é mais do que uma mímica mecânica; é uma forma de actividade criativa” - na qual é preciso entender o que há de essencial na ação de alguém e entender que há uma construção própria daquela pessoa que vai imitar - ele torna presente a questão do aprender com os professores que tivemos, até pela negação, se for o caso, como afirmou um dos professores do meu estudo: "tive bons e não tão bons professores. Com os não tão bons aprendi o que não se deve fazer em sala de aula. Tive professores dedicados e aprendi muito com eles".

Em outras palavras, além da reflexão, há o saber da história pessoal/profissional da pessoa, que constitui o seu background, a sua experiência que é, também, fruto da imitação no sentido atribuído por Schön. Entendo que na imitação reflexiva nos apropriamos de outras 
experiências, mas refletimos sobre elas, integramos o que há de essencial, imprimimos o nosso "tom" e a traduzimos como um ato de nossa criação ou recriação reflexiva.

Ele aponta como dificuldades para a reflexão na e sobre a prática quanto à formação de professores a epistemologia dominante na universidade (a racionalidade técnica) e o currículo profissional normativo.

Alerta que este movimento crescente em torno de uma prática reflexiva encontra-se no centro de um conflito epistemológico: o ressurgimento da racionalidade técnica nas universidades. Os riscos deste conflito de epistemologia são altos, "pois o que está em causa é a capacidade para usarmos as facetas mais humanas e criativas de nós próprios" (p.91).

Retomando a questão da racionalidade técnica, colocada por Schön em 1983, Pérez Gómez afirma que nela o professor passa a ser um técnico. Por esse modelo, a atividade do professor é "instrumental, dirigida para a solução de problemas mediante a aplicação rigorosa de teorias e técnicas científicas" (Pérez Gómez, in: Nóvoa, 1992a, p.96).

Nesse modelo, as ciências aplicadas, apoiadas nos princípios das ciências básicas geram o conhecimento técnico e o desenvolvimento de competências profissionais.

Não é apenas uma questão de hierarquia dos campos de conhecimento. $\mathrm{Na}$ verdade as pessoas estariam, conforme sua atividade, encaixadas num ou noutro caso. Aquele que executa, o faz apoiado nas investigações de outros que detém o conhecimento aplicado, os quais por sua vez se reportam àqueles que investigaram os temas básicos. A esta subordinação dos níveis do conhecimento estaria também associada uma subordinação mais perversa: o que está mais próximo da atividade prática estará executando algo com vistas a uma meta que foi definida por alguém que detém um conhecimento mais abstrato. "As derivações normativas da racionalidade técnica tipificaram uma proposta rígida para a formação de professores, centrada no desenvolvimento de competências e capacidades técnicas" (p.99).

Colocar a atuação do professor no contexto de um modelo de racionalidade técnica é, numa situação extrema, restringir sua atuação a atividades já previamente determinadas e nas quais ele não tem participação em suas definições. É o caso das políticas educacionais centralizadas, com currículos definidos em gabinetes distantes das atividades reais da escola, com materiais instrucionais definidos (livro texto, por exemplo) e, numa 
situação em que a atividade profissional é reduzida a um mínimo, até com planos de aula impostos. Como exemplo, pode-se citar a descrição de Popkewitz (in: Nóvoa, 1992a, p.41-42) que, analisando a profissionalização do ensino nos Estados Unidos, detecta ao longo dos anos, uma diminuição da responsabilidade dos professores através da burocratização, chegando ao ponto em que o ensino ficou subordinado às competências específicas. Nóvoa, analisando a profissionalização dos professores portugueses, constata que ali também ocorreu uma separação entre a concepção e a execução, sublinhando "as características técnicas do trabalho dos professores, provocando uma degradação do seu estatuto e retirando-lhes margens importantes de autonomia profissional" (Nóvoa, 1992a, p.24). Há uma tendência generalizada de delegar aos especialistas a elaboração dos programas, legitimando sua intervenção, e deixar aos professores a concretização pedagógica dando, então, características técnicas ao seu trabalho, o que provoca a retirada da autonomia dos professores.

Não se pode desconsiderar os defeitos e limites da racionalidade técnica, pois na sala-de-aula, por exemplo, os acontecimentos se caracterizam pela "complexidade, incerteza, instabilidade, singularidade e conflito de valores” (Pérez Gómez, in: Nóvoa, 1992a, p.99), que são características do conhecimento prático.

Os limites da racionalidade técnica não implicam, entretanto, em abandoná-la em qualquer situação da prática educativa. Segundo Pérez Gómez,

"o que não podemos é considerar a actividade profissional (prática) do professor, como uma actividade exclusiva e prioritariamente técnica. É mais correcto encará-la como uma actividade reflexiva e artística, na qual cabem algumas aplicações concretas de caráter técnico" (Pérez Gómez, in: Nóvoa, 1992a, p.100).

Neste sentido, cabe integrar de forma criativa, conhecimento e técnica, o que é denominado por Schön como "conhecimento prático" necessário no "processo de reflexão-na-ação" ou "diálogo reflexivo com a situação problemática concreta" (apud Pérez Gómez, in: Nóvoa, 1992a, p. 102).

É importante frisar que a reflexão é um conhecimento alicerçado na própria experiência de vida da pessoa. Segundo Schön, há três conceitos que formam o pensamento prático do professor e que garantem 
uma intervenção prática racional: conhecimento-na-ação; reflexão-na-ação; reflexão sobre a ação e sobre a reflexão-na-ação.

O conhecimento-na-ação "é o componente inteligente que orienta toda a actividade humana e se manifesta no saber fazer". Ao "saber fazer" deve estar associado o "saber explicar o que se faz"principalmente para os professores - o que supõe a reflexão (Pérez Gómez, p.104).

A reflexão-na-ação é um novo conhecimento que surge sobreposto ao anterior, que levava à ação. O autor denomina-o de conhecimento de segunda ordem em contraposição ao anterior denominado conhecimento de primeira ordem. Ele tem a riqueza da

"captação viva e imediata das múltiplas variáveis intervenientes e a riqueza da improvisação $e$ criação". (...) "Quando o profissional se revela flexível e aberto ao cenário complexo de interacções da prática, a reflexão-na-acção é o melhor instrumento de aprendizagem”, [pois se adquirem e se] "constroem novas teorias, esquemas e conceitos, [assim] como se aprende o próprio processo dialéctico da aprendizagem" (Pérez Gómez, in: Nóvoa, 1992a, p.104).

A reflexão sobre a ação e sobre a reflexão-na-ação é a análise que se faz "a posteriori sobre as características e processos da sua própria acção" (p.105). É quando o professor evoca os "vestígios" que lhe ficaram na mente e os analisa e avalia, sem os condicionantes da situação prática em que os fatos ocorreram, o que lhe permite melhor compreensão e reconstrução da prática. $\mathrm{O}$ autor classifica-a como um instrumento essencial para a formação continuada porque o professor, individualmente ou com seus pares, reconsidera a situação problemática com todas as suas características e, ainda, reflete sobre os esquemas de pensamento, as convicções, as formas que ele tem para representar a realidade, quando está diante de situações novas. Este tipo de reflexão "supõe um conhecimento de terceira ordem pois analisa o conhecimento na acção, a reflexão na acção e estabelece a relação com a situação e o contexto” (p.105).

Quando a prática se torna repetitiva e rotineira e o conhecimento-na-ação é cada vez mais inconsciente e mecânico "o profissional corre o risco de reproduzir automaticamente a sua aparente competência prática e de perder valiosas oportunidades de aprendizagem pela reflexão na e sobre a acção” (p.105). A reflexão-na-ação também só 
não basta, pois está condicionada pelas situações presentes no momento da ação. Só a reflexão a posteriori permite, com os instrumentos racionais disponíveis, entender e tirar lições da situação prática vivida.

De maneira bastante feliz o autor considera que a vida profissional do professor é permeada continuamente por situações para as quais não há respostas pré-elaboradas. São situações onde também não pode ser aplicado o processo clássico de investigação científica.

“... as realidades criam-se e constroem-se no intercâmbio psicossocial da sala de aula. As percepções, apreciações, juízos e credos do professor são um factor decisivo na orientação desse processo de produção de significados, que constituem o factor mais importante do processo de construção da realidade educativa” (Pérez Gómes, 1992a, p.110).

Não há, portanto, uma solução absoluta. Cada problema e cada situação requerem enfrentamentos e soluções a serem aprendidos e aplicados nas situações práticas.

Ainda destacando "o valor da prática como elemento de análise e reflexão do professor", Garcia relata os estudos de Schulman sobre os diferentes tipos de conhecimentos que os professores podem adquirir, concluindo que o de

"maior interesse, do ponto de vista didáctico é o conhecimento de conteúdo pedagógico, uma vez que representa uma combinação entre o conhecimento da matéria e o conhecimento do modo de ensinar" (Garcia, in: Nóvoa, 1992a, p.57).

Tal conhecimento foi considerado importante e diferenciado por não poder ser adquirido "de forma mecânica ou linear" e nem poder ser ensinado, pois representa a construção pessoal do professor no momento de transformar o conteúdo em ensino (p.57).

Assim, para aliar à competência acadêmica, uma competência pedagógica, isto é, ao domínio dos saberes da área específica de seu conhecimento, o domínio do seu ensinar, o professor necessita desse saber denominado por Shulman de "conhecimento de conteúdo pedagógico". Sua contribuição é valiosa, pois resgata a importância de saber o que se está ensinando e quais conhecimentos da sociedade e do universo psicológico do aluno são importantes. Com base na análise reflexiva, o professor utiliza o conhecimento específico, o conhecimento 
sobre o ensino, o conhecimento do aluno, os exemplos conhecidos, as experiências passadas e elabora a síntese pessoal, no contato com o ensino.

O autor - a exemplo dos anteriores e de outros que a literatura apresenta - destaca a reflexão, a prática docente, a experiência, a formação continuada, caracterizando um período rico em termos de tentativas de explicação do fenômeno educacional e, particularmente, do ensino e da aprendizagem.

Garcia destaca, ainda, opinião (que já externei) de que “os professores possuem teorias sobre o que é ensino”. Referindo-se aos estudos de Marland \& Osborne, o autor conclui que 'estas teorias, que influenciam a forma como os professores pensam e actuam na aula, permanecem provavelmente inconscientes para os professores ou, pelo menos, pouco articuladas internamente,” (p.60).

Essa condição de adormecimento pedagógico faz com que o professor não seja senhor de seus sonhos e de seus atos e permaneça numa situação enfraquecida de transmissor do saber alheio e executor dos projetos dos outros, anulando as chances da conquista da sua profissionalidade. Nóvoa é brilhante ao definir que "no fundo, o que está em causa é a possibilidade de um desenvolvimento profissional ( individual $e$ colectivo ), que crie as condições para que cada um defina os ritmos e os percursos da sua carreira e para que o conjunto dos professores projecte o futuro desta profissão, que parece reconquistar, neste final de século, novas energias e fontes de prestígio" (1991, p.28. Grifos do autor).

Realçando este "desenvolvimento profissional, na dupla perspectiva do professor individual e do colectivo docente", como o "eixo de referência da formação”, Nóvoa explicita as dimensões: pessoal, profissional e organizacional, na profissão docente ( 1992a, p.24).

Elas estão ligadas e são interdependentes. Tudo o que é elaboração pessoal entra em cena, pois é preciso considerar a pessoa que faz a mediação e o modo como é feita. Essa pessoa é o professor e o fator pessoal está atrelado ao desenvolvimento profissional e organizacional. A inexistência de um projeto pedagógico nacional e institucional e a inexistência de um comprometimento profissional com a docência, com a própria atuação, vai prejudicar essas duas dimensões. Neste sentido, o papel 
da instância formadora é básico na formação inicial, mas também o é em se tratando da formação profissional continuada.

Nóvoa justifica que o desenvolvimento pessoal é responsável por produzir a vida do professor. O desenvolvimento profissional produz a profissão docente e o desenvolvimento organizacional produz a escola. O primeiro tem sido "sistematicamente ignorado" e os outros dois não têm sido valorizados numa articulação, que é desejável, "entre a formação e os projectos da escola" (p.24).

A formação é um processo que tem como referência a identidade e as experiências da pessoa/profissional - profissional/pessoa, segundo se coloca, no presente momento, pela linha dos "estudos do pensamento do professor".

Tem sido enfatizada a formação que: - seja crítico/reflexiva sobre a prática; - proporcione pensamento autônomo; - facilite a autoformação participada; - requeira investimento pessoal, livre e criativo; - encontre espaços de interação pessoal/profissional; - permita apropriação dos processos próprios de construção; - dê sentido à dimensão pessoal e profissional no quadro da história de vida; - valorize a experiência.

Referindo-se a vários autores, Nóvoa enfatiza a importância da experiência, destacando que ela é o único processo para uma "transformação de perspectiva e uma produção pelos próprios professores de saberes reflexivos e pertinentes". E ainda, que as vivências e experiências é que dão sentido e se ligam de maneira indissociável à formação dos professores. Lamenta que a organização das escolas desencoraje o investimento nas experiências significativas dos professores e se omita quanto à avaliação de suas realizações, numa perspectiva individual e, principalmente, conjunta (p.26. O grifo é meu).

Não se trata, evidentemente, de encorajar toda e qualquer experiência, pois como ponderou um aluno em sala de aula, "uma valorização indiscriminada ao saber de experiência do professor poderá instalá-lo numa atuação docente que foi, na vida do aluno, um divisor de águas não-positivo".

Neste sentido, o autor defende as práticas coletivas de formação por consolidarem a profissão dos professores, que é "autónoma na produção dos seus saberes e dos seus valores” (p.27). 
Defende as medidas: - valorizar paradigmas de formação que preparem professores reflexivos, responsáveis pelo próprio desenvolvimento profissional e participantes nas políticas educativas; - investir positivamente nos saberes do professor e trabalhá-los de um ponto de vista teórico e conceitual; - valorizar as capacidades de autodesenvolvimento reflexivo que os competentes têm, tendo em vista que os professores enfrentam situações com características particulares que exigem respostas únicas.

Afirma que os "saberes experienciais e as práticas dos professores" têm sido desvalorizados pela "pedagogia científica" que dá força à razão instrumental. "A lógica da racionalidade técnica opõe-se sempre ao desenvolvimento de uma práxis reflexiva” (p. 27).

Fiz referência, em páginas anteriores, à não-consideração, pelo próprio professor, do seu saber e prática e da não-partilha de saberes e experiências, como também me referi ao fato de que considero difícil ser a atividade profissional do professor, exclusivamente técnica. Admito que ele sufoca sua racionalidade prática ou não a explora "como uma actividade reflexiva e artística, na qual cabem algumas aplicações concretas de caráter técnico", pelo menos no nível do ensino superior e, principalmente, em áreas como a Física (Pérez Gómez, in: Nóvoa, 1992a, p.100).

$\mathrm{Na}$ formação inicial, seja no magistério de $2^{\underline{\underline{o}}}$ grau ou na universidade, o professor não encontra a possibilidade formativa plena. É um início de formação que vai se dar ao longo do exercício profissional. Ela dispara as necessidades e as sensibilidades para um tipo de formação e para que a pessoa seja aberta à consulta contínua à literatura, a criar outras estratégias, a tomar decisões em sala de aula, a entender o ser humano com quem está lidando, enfim, a elaborar pessoalmente as experiências.

O desempenho mecânico dos procedimentos, sem o questionamento da própria atuação, vai perpetuar concepções equivocadas da formação e da própria natureza da função docente.

Vários autores têm problematizado a profissionalização do professor. Discussões sobre profissionalização e proletarização, profissionalidade, semi-profissão e outras questões têm sido feitas, principalmente em se tratando do professor de $1^{\underline{0}}$ e $2^{\underline{0}}$ graus. O professor de $3^{0}$ grau tem uma profissão? Sua profissão é a de pesquisador? O magistério que ele exerce é profissão? Uma possível neutralidade ou não-envolvimento efetivo do professor na universidade poderia ser explicado - além da atração e compensação institucional que a pesquisa exerce - pela 
desprofissionalização do professor de $3^{\underline{0}}$ grau? Estes pontos merecem reflexão, lembrando que enquanto permanecer a concepção de senso comum de que "qualquer pessoa é professor" e perdurar a desvalorização social, impingida pelos governos, não será defendida a necessidade da profissionalização porque na base dessa conquista tem que estar firmemente presente que ser professor é, sim, uma profissão e deveria ser altamente valorizada nos aspectos político, econômico e social.

Sintetizando as colocações feitas nesse capítulo, destaco que a experiência é apontada como elemento fundamental para a construção de uma prática docente eficaz e centrada no aluno como produtor do conhecimento. Nóvoa firma a necessidade de se tomar consciência que o conhecimento adquirido com a experiência encontra-se inserido num valioso quadro conceitual de produção de saberes. Infelizmente, a estrutura universitária atual desconsidera quase totalmente o significado e a importância desse tipo de construção do conhecimento. Essa problemática organizacional tem colocado empecilhos ao melhoramento das atividades de muitos profissionais envolvidos com a docência. Martins discute a questão da integração/separação entre ensino e pesquisa no seu trabalho, apontando que apenas a pesquisa é encarada como fonte de busca do saber. Nesse aspecto, a acepção ampla de pesquisa, utilizada por Demo, vem aclarar a importância do ensino não só para a construção do saber mas também para o relacionamento social dos indivíduos envolvidos com o processo de ensino e aprendizagem.

Paralela à experiência, há a reflexão que também exerce papel relevante, pois é através de uma análise dos acontecimentos ocorridos na sala de aula, realizada a posteriori, que novos direcionamentos podem ser adotados. Schön e Pérez Gómez constituem o corpo teórico que, principalmente a partir dos anos 90, tem influenciado outros pesquisadores com a proposição da reflexão-na-ação e sobre-a-ação. Percebo que tal proposição insere uma nova dimensão às discussões sobre a construção da prática docente uma vez que chama a atenção para a análise dos fenômenos na dinâmica própria da sala de aula.

Nóvoa salienta as dimensões: pessoal, profissional e organizacional, envolvidas no trabalho docente. Quanto à dimensão pessoal, há um vínculo com aquilo que Lima chama de "memória educativa" ou seja, a maneira como a história de vida do sujeito (apontada por Cunha) influencia a sua maneira de encarar o processo de ensino quando irá atuar como professor. Também Pimentel aproxima-se de tal consideração ao mencionar que a construção da prática docente envolve mudanças de 
concepção de mundo, homem, conhecimento, sociedade, ensino e ciência, enfim mudanças pessoais. Dessa maneira, é paradoxal a atitude de relegar o ensino a um segundo plano com a alegação, pelos professorespesquisadores, de que não são capazes de questionar a sua própria prática docente e refletir sobre ela. Tais profissionais estão habituados a se deparar com resultados instigantes em suas pesquisas. A atividade científica propõe reflexões, questionamentos e crises filosóficas que devem ser constantemente respondidas. É incompreensível o motivo que os faz acreditar que a atividade docente não é tão instigante quanto a pesquisa científica.

Sob outro ponto de vista, as considerações de Masetto também possuem traços em comum com a "dimensão pessoal" de Nóvoa. Em seus trabalhos, Masetto insiste na importância de um ambiente acolhedor na sala de aula, onde as relações sejam norteadas por um clima regido por atitudes de troca de experiências através das quais a "convivência" possa produzir significados que se relacionem com a "realidade".

Nos trabalhos de vários autores citados, notadamente Grígoli e Tancredi, recebem destaques as considerações acerca do que seria um "bom professor" sob o ponto de vista dos alunos. Tais pesquisas constituíram, em grande parte, confrontações entre o "professor ideal" e o "professor real" encontrado pelos alunos nas universidades. A despeito das características já apontadas, nota-se que, durante sua vida, o aluno vai formando uma imagem de "bom professor" e de ensino, a partir de suas satisfações e frustrações no dia-a-dia. Tal "acervo" de atitudes docentes vai determinar, em alguma medida, seu comportamento como futuro professor. Nota-se, portanto, a ocorrência daquilo que Schön chama de imitação reflexiva, ou seja, a aplicação crítica e "filtrada" de práticas adquiridas durante a vida estudantil.

Um aspecto salientado no meu trabalho, e que tem consonância com vários autores apontados é a necessidade da troca de experiências entre os docentes. Behrens e Lima, por exemplo, apresentam projetos de formação continuada do professor, nos quais o trabalho coletivo de leitura e produção de textos possui papel preponderante. Lima, inclusive, apregoa a existência de um esforço para que o conhecimento pedagógico desenvolvido nas atividades coletivas seja transformado em saber artístico através de atividades que estimulem a criatividade dos docentes. Tais proposições são concordantes com Schön e Pérez Gómez que salientam a forte conotação artístico-criativa, existente na atuação docente. Conforme aponta Pérez Gómez, a prática do professor deve ser encarada "como uma actividade reflexiva e artística, na qual cabem [também] algumas 
aplicações concretas de caráter técnico" (Pérez Gómez, in: Nóvoa, 1992a, p.100). Assim, através das afirmações mencionadas, chega-se à conclusão de que o ponto comum é que a docência se encontra num meio caminho entre o saber técnico-científico e o saber artístico-criativo, por isso o professor diferenciado deve ter o conhecimento do pesquisador proficiente e o desempenho pedagógico do artista inovador. 


\section{OS CAMINHOS DA INVESTIGAÇÃO}

"A vida daquele que compreende, torna-se extraordinariamente interessante e intensa. Todo instante está rodeado de uma magia que convida à meditação". Juan José Mouriño Mosquera

Como já explicitado, o foco de interesse que originou este estudo foi a compreensão da prática docente de professores-pesquisadores em Física no $3^{\circ}$ grau.

Os docentes universitários não têm, obrigatoriamente, contato com as disciplinas pedagógicas nos seus cursos de graduação.

Esse é o caso, por exemplo, dos engenheiros, médicos, advogados e outros profissionais que, ao término da sua formação universitária, ou mesmo após alguns anos de exercício profissional, optam pela docência como atividade integral ou parcial.

O mesmo acontece em outros cursos onde é relativamente comum encontrar-se parcela significativa do corpo docente (físicos, químicos, biólogos) cuja opção foi pelo Bacharelado e não pela Licenciatura na sua formação universitária.

Tal situação não se alterou quando, nos últimos anos, os docentes universitários passaram a ser recrutados ao término da pósgraduação (mestrado ou doutorado).

De um lado é suposto que o professor que domina o conteúdo a ser ensinado encontra os caminhos para ministrá-lo e, ainda, que 
as habilidades específicas para o ensino são importantes nos níveis anteriores de escolaridade e dispensáveis na universidade.

Por outro lado, a contratação de docentes considera, geralmente, a capacitação para a pesquisa nos campos de interesse das unidades universitárias, o que leva à opção por pesquisadores.

Assim, ao procurar investigar como ocorre sua prática docente, está sendo destacada uma das dimensões da sua formação que é aquela mais identificada com as suas características pessoais, muito embora tal dimensão pessoal não tenha acontecido desvinculada do contexto da instituição formadora e nem separada do enfoque profissional ou profissionalizante do qual sua formação foi objeto. Nesse sentido, a prática, a experiência e a reflexão que intrinsecamente o professor faz sobre a sua atuação como docente e a intuição que ele segue, estão sendo enfocadas sem prejuízo da importância dos demais aspectos relacionados à profissão docente.

No IFSC/USP, onde foi realizado este trabalho, o aspecto de contratação docente no $3^{\underline{0}}$ grau não tem fugido à realidade acima exposta.

Há, no entanto, docentes que manifestam preocupação pedagógica e demonstram interesse também pelo ensino. Como essas motivações se concretizam no cotidiano das suas salas de aula?

A natureza deste estudo possibilitou a abordagem qualitativa de pesquisa tendo sido o Estudo de Caso, a forma utilizada, por ir ao encontro da finalidade de se compreender a prática docente de professores-pesquisadores de Física, nos cursos de Bacharelado e Licenciatura.

André (1992, p.38), sintetiza as ideias de vários outros autores quanto ao Estudo de Caso dever ser usado:

"1) quando se está interessado numa instância em particular, isto é, numa determinada instituição, numa pessoa ou num específico programa ou currículo; 2) quando se deseja uma visão profunda e holística do fenômeno investigado; 3) quando se quer conhecer as diferentes percepções que os participantes do caso têm sobre ele; 4) quando se busca descobrir novas hipóteses teóricas, novas relações, novos conceitos sobre um determinado fenômeno; e 5) quando se quer retratar o dinamismo 
de uma situação numa forma muito próxima do seu acontecer natural”.

No presente Estudo de Caso sobre a prática docente, foram utilizados os depoimentos e atuações em aula, de dois professores do Bacharelado e dois da Licenciatura.

Os critérios que nortearam a referida escolha foram os seguintes: quais dos professores do Instituto de Física de São Carlos, em conversas informais, ou pelas atividades que realizam, ou pelas tentativas e concretizações de trabalhos também voltados para o ensino, haviam demonstrado preocupação pedagógica, ou manifestado considerar o ensino tão importante quanto a pesquisa na universidade, ou verbalizado que os cursos do Bacharelado também deveriam ter (boas) disciplinas pedagógicas. Em outras palavras, a escolha ocorreu em função da percepção, devido à convivência profissional na mesma Instituição, de que o que estes professores realizam na docência é denotativo da preocupação com o ensino, além daquela evidenciada na pesquisa e/ou extensão.

Dentro destes critérios, os professores sujeitos do estudo, podem ser assim descritos:

Prof. A - É professor do Bacharelado e da pós-graduação em Física. Orientador de Iniciação Científica, Mestrado e Doutorado. Sua graduação foi no Bacharelado em Física e Engenharia de Materiais. É professor universitário desde 1981. Já demonstrara preocupação com o ensino quando, em 1992, introduziu uma alternativa metodológica em um curso básico de Física que apresentava, sucessivamente, altos índices de repetência e evasão. Ele desejava que o seu curso fosse avaliado por um observador externo, da área de Educação. Desenvolvi, então, um projeto de avaliação educacional e acompanhei todas as aulas do curso de Mecânica Geral para a Engenharia, por um semestre, inclusive as Aulas Demonstrativas introduzidas, fazendo observação em sala de aula e aplicando questionários a alunos: ingressantes, reprovados em anos anteriores, depois de cada Aula Demonstrativa e, finalmente, aos aprovados e reprovados após a alternativa metodológica, ou seja, ao fim do semestre letivo. O trabalho foi apresentado em Congresso ${ }^{62}$ e publicado em revista de Ensino de Física ${ }^{63}$. Eu conhecia, portanto, seu interesse e preocupação com o ensino de graduação.

\footnotetext{
${ }^{62}$ V Reunião Latino-Americana sobre Educação em Física, Porto Alegre, agosto, 1992.

${ }^{63}$ Barreiro A.C.M. e Bagnato, V.S. - Aulas Demonstrativas nos Cursos Básicos de Física Caderno Catarinense de Ensino de Física - v.9, nº 3 dez/92 - p. 238-244.
} 
Prof. B - É professor do Bacharelado e da pós-graduação em Física. Orientador de Iniciação Científica, Mestrado e Doutorado. Professor universitário desde 1968. Fez Bacharelado e também Licenciatura em Física na sua graduação. Frequentemente externava sua opinião de que matérias pedagógicas muito bem ministradas deveriam constar do currículo obrigatório também do Bacharelado. Afirmava, ainda, que é preciso investigar a importância da formação pedagógica para o professor universitário. Desafiava à reflexão sobre "que significados têm o fato do currículo não possibilitar formação pedagógica para bacharéis que poderão vir a ser professores da universidade e em que as disciplinas pedagógicas influiriam na atuação dos professores universitários, que fizeram Licenciatura, do ponto de vista do aluno do $3^{-}$grau?" Seu posicionamento é, no mínimo, atípico no contexto dos professores das ciências exatas do $3^{0}$ grau. Além disso, pelas minhas conversas informais com alunos, ao longo desses anos, sei que ele tem boa interação com os estudantes e preocupa-se com o ensino.

Prof. C - É professor do Bacharelado em Física, da Licenciatura em Ciências Exatas e de pós-graduação. Orientador de Iniciação Científica, Mestrado e Doutorado. Graduado no Bacharelado em Física. Professor universitário desde 1985. Ministra cursos no Bacharelado e com a criação da Licenciatura em Ciências Exatas passou a ensinar Física Básica para os licenciandos. É atualmente coordenador da Comissão Coordenadora do Curso de Licenciatura em Ciências Exatas (COC). Participa de projetos do Centro de Divulgação Científica e Cultural (CDCC) direcionados a professores da rede estadual de ensino de São Carlos e região, ministrando cursos. Seu gabinete (sala de trabalho) sempre foi muito concorrido e o atendimento aos alunos é numa constante atitude de muito boa vontade e entusiasmo. Aliada à boa interação com os alunos, sempre manifestou que gosta de ensinar e que considera muito importante também o ensino de graduação.

Prof. D - É graduado em Engenharia Mecânica, com Mestrado e Doutorado em Física. Professor universitário desde 1971. Professor da Licenciatura Diurna e da Licenciatura em Ciências Exatas. Orientador de Iniciação Científica, Mestrado e Doutorado em Física. Ministra uma disciplina profissionalizante e uma específica, ambas do currículo da Licenciatura. Foi coordenador do CDCC desde 1980 e atualmente é seu diretor. Tem, portanto, via extensão, ligação com alunos e professores da Rede de Ensino, através de projetos, cursos, mini-cursos, experimentoteca, videoteca etc, que desenvolve e coordena. 
Não houve problema de aceitação em participar da pesquisa. Um deles (Prof. D) foi um pouco reticente por achar (disse isso) que não havia nada de interessante na sua docência.

A realização do Estudo de Caso implicou no estudo da bibliografia, entrevistas, observação de sala de aula e consulta aos documentos pertinentes. ${ }^{64}$ A coleta de dados foi feita durante o $2^{-}$semestre de 1994.

Como a investigação ocorreu numa dada instituição universitária e em cursos por esta oferecidos, as situações levantadas, as compreensões desencadeadas, as realizações efetivadas, as rotinas elaboradas e modificadas, as tentativas, os acertos e os erros, o enfrentamento de problemas, as inventividades etc., são particulares a este contexto.

Neste sentido, as conclusões não poderão ser generalizadas, muito embora possam perfeitamente ser balizadoras da revisão, do redimensionamento e da compreensão reflexiva sobre temas da capacitação docente.

Optei por realizar a pesquisa através de duas vertentes: como o docente vê e justifica a sua prática e como a mesma é vista por quem a observa. Esse enfoque condicionou a escolha dos instrumentos utilizados: para a primeira vertente foi necessária a realização de entrevistas, enquanto para a outra fez-se necessária a observação de aulas.

afirma que:

Concordo com Schön (in: Nóvoa, 1992a, p.90) quando "não é suficiente perguntar aos professores o que fazem, porque entre as acções e as palavras há por vezes grandes divergências. Temos de chegar ao que os professores fazem através da observação directa e registada que permita uma descrição detalhada do comportamento e uma reconstrução das intenções, estratégias e pressupostos. A confrontação com os dados directamente observáveis produz muitas vezes um choque educacional, à medida que os professores

\footnotetext{
${ }^{64}$ Atas de reuniões, processos, propostas, estrutura curricular, catálogos de cursos, anuários estatísticos, boletins internos, Diário Oficial da União e do Estado, estatutos da USP, portarias, relatórios e resoluções, como consta da Bibliografia.
} 


\section{descobrem que actuam segundo teorias diferentes daquelas que professam”.}

Neste sentido, entrevistas e observações, encaminhadas e realizadas em paralelo, permitiram dados significativos tendo em vista o meu objetivo. Pressupostos teóricos podiam ser (e foram) pontos para perguntas. Opiniões e informações dos entrevistados puderam ser observadas. São essas reconciliações que vão permitindo integrar e diferenciar progressivamente o corpo de dados necessários para a análise.

Respostas e explicações, assim como decisões, ações e, finalmente, análises, dão-se a partir das concepções tanto do pesquisador como do pesquisado. Neste sentido, é importante assumir que entrevistas e observações trazem consigo o caráter de subjetividade. As interpretações, portanto, estão sujeitas às subjetividades e sensibilidades dos envolvidos.

Meu objetivo foi estudar a prática dos professores. Não houve preocupação com aspectos do conteúdo, o que exigiria domínio nas áreas de conhecimento em questão, ou seja, em Física. Minha formação como pedagoga não permitiria análises relacionadas ao conteúdo, mesmo porque estaria me distanciando do objetivo que foi compreender a prática pedagógica dos professores-pesquisadores e não a pertinência e enfoque dos assuntos.

Este aspecto, ao invés de nos afastar, aproximou-nos. De que forma? Os professores se ressentem de "não saber pedagogia", de que "gostariam de saber", e de sentir certa expectativa por responderem perguntas ou serem observados. Identifico-me com eles. Também não domino sua área. Não tenho as soluções - pois são fruto de construção individual - que eles pensam ser prontas e acabadas em termos de "manejo de sala de aula", para quem, segundo eles, "evidentemente sabe dessas coisas", e por também me sentir observada. Somos caminheiros de um mesmo caminho. Seres inquietos, reflexivos (mas também intuitivos), convictos (mas, por vezes, necessitados de certeza), realizados (mas também tão desejosos). Enfim, seres professores de quem tanto já se falou e tanto há para ser dito.

Assisti, semanalmente, a duas aulas de teoria de cada professor sendo que no caso de um deles assisti, também, às aulas de Instrumentação para o ensino. Este (Prof. D) foi, portanto, observado em uma disciplina prática e outra teórica, na Licenciatura diurna e na noturna, respectivamente. Das quinze semanas distribuídas pelo semestre letivo, assisti às aulas de nove semanas, em média. 
A observação das aulas incidiu, basicamente, sobre os procedimentos didáticos, a relação professor-aluno e o envolvimento com a disciplina e com os alunos, porque estes são pontos intrínsecos ao cotidiano da sala de aula e sua dinâmica. Além disso, porque seus significados poderiam permitir a apreensão e compreensão dos fatos ligados à atuação dos professores, ou seja, à sua prática efetiva.

As entrevistas estruturadas foram gravadas ou nas respectivas salas dos professores ou na minha sala, conforme a disponibilidade de cada um deles em termos de local, data e horário. Os entrevistados não ofereceram dificuldades para a realização das mesmas, mas dois foram mais comunicativos (Prof. B e Prof. C) e os outros dois mais breves (Prof. A e Prof. D) nas suas respostas.

A primeira entrevista aos quatro professores foi feita durante o mês de agosto de 1994. Meu objetivo foi obter as opiniões/informações dos professores sobre questões especialmente ligadas à dinâmica de sala de aula.

Essas questões foram pontos de referência para as observações das aulas e registros da atuação do professor.

A segunda entrevista, feita entre a última semana de setembro e o mês de outubro, decorreu da necessidade de ouvi-los com relação a alguns pontos que levantaram durante a primeira, aos aspectos que observei nas aulas, às informações colhidas na literatura e, ainda, sobre questões que se foram evidenciando no processo. Assim, os dois núcleos de informações, constituídos pelas duas entrevistas, permearam a observação.

Utilizei dois roteiros de questões (Anexos 1 e 2) a fim de estabelecer o diálogo. Os entrevistados foram além do que foi perguntado quando queriam introduzir ou explicitar melhor um assunto, como também emitir opiniões. Às vezes, as indicações se transformavam em perguntas complementares.

As entrevistas foram realizadas, gravadas e transcritas por mim. A duração das entrevistas propriamente ditas, variou de 40 minutos a uma hora e meia.

As duas entrevistas com o Prof. A realizaram-se na minha sala. Na primeira, ele batia com os dedos na mesa, pegava a caixinha da fita do gravador e ficava abrindo/fechando ou batendo-a. Não parava com as 
mãos. Eu ficava preocupada se não iria prejudicar a gravação. $\mathrm{Na}$ segunda entrevista foi muito rápido e objetivo nas respostas.

As duas entrevistas com o Prof. B foram na sala dele. $\mathrm{Na}$ primeira, disse que gosta de falar de sua vida pessoal/ profissional. $\mathrm{Na}$ segunda falou que espera colaboração no sentido de críticas e sugestões ao seu trabalho. Manifestou, também, que tem dificuldade com a questão da avaliação e que se incomoda por precisar fazer julgamentos sobre os alunos.

As duas entrevistas com o Prof. C foram na minha sala. Ele falava bastante. Sua expressão foi de atenção e colaboração. Falou que se sentia "em desvantagem" ao falar sobre aspectos educacionais porque "você sabe bem dessas coisas, mas eu não sei. Eu vou fazendo sem saber se está certo".

As duas entrevistas com o Prof. D foram na sala dele. Falava pouco. Era reticente nas respostas. Na segunda vez, reclamou dizendo ter pensado que seriam as observações de aulas e apenas uma entrevista. Ao término, perguntou como seria a análise.

Feita a transcrição das entrevistas - tais como foram gravadas - organizei o conjunto das informações, ou seja para cada questão formulada foram copiadas, sequencialmente, as respostas dadas pelos quatro professores, bem como as intervenções e insistências possibilitadas pelas suas opiniões.

O passo seguinte foi o da elaboração das categorias para que eu pudesse, através delas, proceder à análise dos dados.

As categorias devem ser "utilizadas como "ferramentas intelectuais" na organização do conteúdo. É importante, no entanto, entender que as categorias não ordenam os fenômenos, mas permitem que nos apossemos deles de uma forma mais objetiva" (Nébias, 1990, p. 96).

Como este trabalho objetiva compreender a prática docente, decidi elegê-la como categoria geral e dividi-la em categorias que pudessem permitir essa compreensão, através da organização do conteúdo das entrevistas e das observações. As categorias, por sua vez, agrupam focos significativos das perguntas, respostas e observações. 
Algumas categorias estavam pré-estabelecidas na montagem das entrevistas. Outras, entretanto e principalmente alguns focos, emergiram do tratamento dos dados. O processo de análise não foi, portanto, linear, já que aspectos da verbalização e da atuação dos professores foram destacados ou reagrupados no transcorrer do trabalho, até se chegar a um conjunto de categorias e focos, coerente com os dados coletados.

Dessa forma, as categorias são: Planejamento do Curso, Execução, Interação, Docência, Avaliação, Características do Professor, Experiências Docentes Anteriores, Dimensão Pessoal/Profissional e Binômio Ensino-Pesquisa.

Em Planejamento, o foco de atenção é Preparação. Aspectos como: o professor prepara aula por aula, faz plano detalhado ou esboço, qual o tempo de preparação e procedimentos quando o professor ministra a mesma disciplina em anos subsequentes, foram considerados.

Para Execução, os focos são: aula; recursos/métodos/ técnicas; livro-texto. Referem-se às estratégias em sala de aula, ou seja, recursos, métodos e técnicas adotados para a execução das aulas, o transcorrer da aula propriamente dita e a utilização de livro-texto ou textos próprios, pelo professor.

Em Interação, os focos professor-aluno e concepção sobre o aluno, referem-se a: como o professor encara a interação professor-aluno, como interage, o que faz para facilitá-la, se há preocupação com o clima de sala de aula, como se dirige ao aluno, com que frequência e se dá tempo para as reflexões, perguntas e respostas.

Em Docência, os focos ensino e aprendizagem procuram esclarecer a concepção do professor, como também, sua preocupação com a compreensão pelos alunos, se o cumprimento do programa o perturba, como percebe se os alunos estão assimilando o conteúdo e quais são seus objetivos de ensino e de aprendizagem.

Em Avaliação, o foco é concepção de avaliação. Aqui os aspectos importantes referem-se ao como o professor diz que avalia, se encontra dificuldades em avaliar, se já equacionou o aspecto da decisão quanto ao rendimento escolar pelo aluno, se esse aspecto o incomoda e se está satisfeito com a forma que utiliza para avaliar seus alunos. 
Nas Características do Professor são considerados: gostar de dar aulas, exemplo pessoal, modelos de professores que teve, aprendizagem em serviço, experiência/intuição e improviso/criatividade.

Em gostar de dar aulas, os aspectos norteadores da análise são: a manifestação verbal quanto ao gosto pelo ensino e os motivos. Também é considerada a atitude em sala de aula, do ponto de vista do entusiasmo e envolvimento, como ainda, se os alunos o rodeiam para esclarecer/comentar pontos da aula.

Exemplo pessoal refere-se à responsabilidade que o professor sente, demonstra e verbaliza, quando o aspecto da formação de seus alunos emerge no convívio que se estabelece numa relação que não é só profissional, mas é também pessoal.

Os professores inspiram-se num modelo que tiveram e que os conquistou? Até que ponto isso ocorreu e quanto da conscientização desse fato eles têm?

No decorrer dos anos ocorreram novas aprendizagens também no exercício da profissão docente? De que tipos foram? Quais os fatores que as motivaram? Foram exploradas?

Qual o papel da experiência e da intuição, do improviso e da criatividade na prática docente?

Em Experiências Docentes Anteriores o foco é o monitor, aqui entendido como aquele aluno que ministra aulas com orientação de um docente. Ele não é, portanto, apenas aquele elemento que auxilia o professor esclarecendo dúvidas dos alunos, embora possa, também, fazê-lo.

$\mathrm{Na}$ Dimensão Pessoal/Profissional os focos são: idealizações, expectativas, limitações, conhecimentos e habilidades, fatores de modificação e reflexões pessoais.

Do conjunto desses focos emergem os aspectos: quais são os sonhos e as idealizações do professor; suas expectativas quanto à docência, aos alunos e ao seu curso; seus conflitos e dificuldades; seus conhecimentos e habilidades; o eixo norteador do seu trabalho; os fatores que levaram o professor a modificar sua prática e em que aspectos e as suas reflexões pessoais. 
No Binômio Ensino/Pesquisa, o foco integração/separação pretendeu oferecer as concepções que os professores apresentam nas suas verbalizações quanto à importância de ambas e sua necessária integração e/ou separação.

O quadro abaixo apresenta as categorias utilizadas na análise.

\section{CATEGORIA GERAL: A PRÁTICA DOCENTE}

\section{CATEGORIAS}

\section{Planejamento do Curso}

Execução

Interação

Docência

Avaliação

Características do Professor

Experiências Anteriores

Dimensão Pessoal / Profissional

Binômio Ensino /Pesquisa

Definidas as categorias, foram transcritos, das entrevistas e dos registros de observação, os trechos correspondentes a cada professor, em cada categoria e foco, organizando-se, assim as verbalizações e as ações dos professores.

Tal organização não foi fácil, devido, principalmente, a dois motivos. Um deles refere-se ao fato de que as situações da dinâmica de 
sala de aula são imbricadas. As categorias são interligadas e na prática nenhum aspecto é autônomo. O outro diz respeito à não-linearidade nas respostas, isto é, nem sempre as ideias centrais das respostas se referiam às ideias centrais das perguntas. Os professores, às vezes, explicitavam os mesmos pontos em momentos diferentes.

Foi um trabalho cauteloso para não se quebrar o contexto, nem atomizar a compreensão sobre o docente e sua prática.

Na sequência, estes dados foram organizados em quadros esquemáticos para um mapeamento global das entrevistas e registros de observação, no sentido de um instrumento provisório de trabalho de análise. Os quadros tinham dupla entrada em que as linhas correspondiam às categorias e/ou focos, e as colunas se referiam a cada um dos quatro professores.

Apoiada na formulação de Pérez Gómez (in: Nóvoa, 1992a, p.102) quanto às práticas dos professores como suportes para a compreensão de como experimentam, modificam e aplicam conhecimentos, situações e técnicas, iniciei a análise tentando sistematizar o que havia observado e ouvido deles, propondo-me ir ao encontro do que apresentavam de elaboração pessoal/profissional, traduzida como a sua prática docente.

Parti, portanto, do pressuposto de que os professores, à luz da formação, das experiências que acumularam e dos valores e convicções próprias, estruturam um modo de ser e de proceder na docência, que não é, muitas vezes, totalmente consciente nem mesmo para seus autores, no aspecto da tomada de consciência já mencionada neste estudo.

Não me moveu objetivo de submeter sua prática ao crivo de formulações teóricas para enquadrá-la ou não e decidir quanto à sua validade.

Conhecer e compreender essa prática foram meus propósitos principais. O conhecimento possibilitado pelas pesquisas, trabalhos e teorias sobre capacitação docente puderam me proporcionar as condições para compreender melhor os professores e talvez, então, tentar iluminar seu contexto, por meio das propostas que atualmente se apresentam, de posturas mais reflexivas que oferecem elementos importantes para a formação inicial e continuada de professores de áreas semelhantes.

Assim, todas as categorias e focos foram explorados principalmente com as verbalizações dos professores e as observações em 
sala de aula. As minhas interpretações e as elucidações/enriquecimentos proporcionados pela literatura consultada compareceram dentro do espírito norteador acima descrito.

Não foi obedecida, na análise, a sequência apresentada no quadro, tendo em vista o privilégio concedido às falas e ações dos professores. Em outras palavras, a articulação entre categorias e focos decorreu muito mais das inter-relações entre as informações faladas e presenciadas do que de uma linearidade pré-definida. 


\title{
5. DA PRÁTICA AO RELATO
}

\author{
"Caminhante, o caminho não existe. \\ O caminho se faz no caminhar". \\ Juan Manuel Serrat
}

Apresentei, em outro capítulo desse trabalho, a análise de várias pesquisas sobre o ensino superior, realizadas nos últimos anos, bem como estudos de autores que enfocam a questão da formação continuada. Foram referenciados, também, artigos que retratam propostas ou experiências em andamento sobre a atividade didática no $3^{\circ}$ grau. Todo esse material, que se complementa será, agora, relacionado a uma tentativa de ampliação de conhecimentos a respeito de procedimentos didáticos, relação professor-aluno e envolvimento com a dinâmica da sala de aula.

Entendo, portanto, ser este o momento de resgatar e apresentar as opiniões, questões e ações dos professores sujeitos desse estudo, relacionadas às salas de aula, às características do professor, às suas concepções de ensino e de aprendizagem e outras (assim denominadas) categorias e seus focos, da categoria geral Prática Docente, dentro do espírito norteador proposto por Pérez Gómez de que é preciso partir da "análise das práticas dos professores quando enfrentam problemas complexos da vida escolar, para a compreensão do modo como utilizam o conhecimento científico, como resolvem situações incertas e desconhecidas, como elaboram $e$ modificam rotinas, como experimentam hipóteses de trabalho, como utilizam técnicas e instrumentos conhecidos e como recriam estratégias e inventam procedimentos e recursos" (In: Nóvoa, 1992a, p.102). 
O que caracteriza o professor? Mais especificamente, o que distingue um físico-professor de outro físico? Em primeiro lugar, ele precisa gostar de dar aulas. O gosto pelo ensino foi posição assumida pelos quatro professores, com opções diferentes quanto às condições subjacentes para explicar este gosto, como por exemplo: sei" (Prof.A).

“... gosto de transmitir para as pessoas um pouco daquilo que “... ainda estudante, no $2^{\underline{0}}$ ano, passei da Engenharia para a Física. Fiz essa opção por gosto. Realmente gosto de ensinar, me realiza como pessoa" (Prof. B).

“... é um gosto, uma vez que se sabe algo, querer contar. Esta é uma motivação básica. Por outro lado, acho que aprendo também. Gosto de dar aula, sem dúvida nenhuma" (Prof.C).

O gostar do que faz e o gostar de dar aulas foram complementares. Apontaram que:

"Gostaria de ter mais tempo para preparar as aulas e daria mais aula se fosse possível, mas a pesquisa exige muito" (Prof. A).

"Desde o $2^{\underline{0}}$ ano como aluno, o que me cativou mais foi o trabalho no laboratório e as aulas que eu ajudava dar. Realmente me realizo ao passar para os alunos o que sei" (Prof. B).

"Gosto do contato com os alunos, falar coisas que já aprendi, já passei pela experiência." (Prof. C).

“... gosto de dar aulas participativas, experimentais. Não gosto de dar aula expositiva, mas sei que ela também faz parte” (Prof. D).

Percebi, nas respostas dos professores, quanto ao foco gostar de dar aulas, na categoria características do professor, aparecerem pontos que são recolocados em diversos momentos das entrevistas. Nas verbalizações acima, por exemplo, podemos perceber aspectos que se referem ao ensino e à pesquisa, à interação professor-aluno, ao planejamento, à execução das aulas e às dificuldades pessoais e profissionais quanto a métodos e técnicas. Neste sentido, poderão ser feitas inter-relações entre as classes de respostas.

Os aspectos de "passar para os alunos" o que sabe e dar aula expositiva, aparecem como natural para um professor e algo que é obrigatório para outro. Ambos são professores da Licenciatura. A transmissão do conhecimento é, na realidade, a especificidade do ato pedagógico. O professor é mediador entre o conhecimento e o aluno. Ocorre que esta mediação precisa ser entendida. Não é só o que aprendeu na escola, nos livros e nas informações que garantem o professor. Há a 
trajetória dele, como elabora os valores, como se relaciona com os alunos, seus preconceitos e discriminações, o não-verbal na sala de aula, suas vivências, e todo um "mundo" que precisa ser visto e compreendido como conteúdo, e cuja execução precisa incorporar a integração, a análise e a reflexão. São fontes que significam alternativas em relação à pura eficácia técnica da transmissão. Descrevem não só a restrita cientificidade do ato pedagógico e nem apenas a parte afetiva.

Em se tratando, ainda de gostar de dar aulas, um primeiro aspecto - sem que esta ordem implique uma escala de prioridade da característica da prática docente - observado nos professores, é o entusiasmo com que eles desenvolvem sua atividade docente. Apesar das diferenças pessoais que modificam o modo como demonstram sua dedicação à atividade docente, aquele entusiasmo se manifesta em diversos momentos da aula e não ocorre isoladamente, estando de fato imbricado com outros aspectos da atividade desenvolvida, como, por exemplo, a preparação e a interação com os alunos.

Revela, por outro lado, que a atividade em sala de aula é prazerosa para o indivíduo, sendo que tal fato ficou patenteado nas entrevistas, pelas respostas positivas sobre a satisfação e o gosto pelo desenvolvimento da atividade docente.

Para dois professores, apesar dos critérios avaliativos da universidade privilegiar a pesquisa na ascensão da carreira acadêmica, a atividade docente é vista como uma possibilidade de realização pessoal (Prof. B e Prof. C).

Outra característica que despontou desde as primeiras aulas observadas foi a preocupação com a compreensão do aluno. Tal aspecto ocorria constantemente no decorrer das aulas, manifestado pela retomada de temas ou detalhes abordados anteriormente e que, nas perguntas dos alunos sobre assuntos encadeados, posteriormente denotavam alguma falha de compreensão. Aqui também se deve considerar que essa característica está de certo modo relacionada com a interação professor-aluno, já que esta possibilita ou não o afloramento daquelas dúvidas na medida em que pode favorecer ou não a manifestação do aluno durante a aula.

Dessa forma, pude observar atitudes semelhantes nos professores e vou descrever algumas delas. Eles explicam com boa vontade, retomando o assunto. Intercalam com exemplos simples e brincadeiras para descontração. Deslocam-se pela sala, vão perto dos alunos, observam e falam com eles. São dinâmicos e seguros nas explicações, entusiasmados e 
exigentes. Demonstram empolgar-se com o assunto. Dizem quando o exemplo é interessante, quando ele tem aplicação e explicam o porquê.

Ao término de uma das aulas do professor B, uma aluna manifestou estar gostando muito do curso porque percebia onde poderia aplicar o que estava aprendendo e quais eram os fenômenos físicos implicados. Suas experiências tinham sido com professores que só explicavam matematicamente como se, daí, o fenômeno físico ficasse, pela resolução matemática, resolvido. "E não é assim porque aí você aprende matemática, mas não vê a relação com a Física e, principalmente, não tem a compreensão. No caso dessa disciplina eu sei resolver porque compreendi o aspecto da Física", ela disse.

Quando se afastou, o professor externou sua satisfação: “eu gosto é dessa manifestação de estarem entendendo que Física não é Matemática. A Matemática é uma ciência sistematizadora, organizadora da mente, do conhecimento físico e por isso ela é importante. Se o aluno sabe resolver tudo matematicamente, não significa que ele compreende a Física. O mundo que nos cerca é um mundo físico, explicável pela Física. A Matemática é importante ciência organizadora deste conhecimento". Disse que tem por hábito questionar-se sobre as explicações da Física para as coisas que vivencia como cidadão comum e ilustra as aulas com os exemplos que fazem parte do Universo e do cotidiano. Busca "motivação em assuntos que a própria ciência oferece".

Os professores B e C demonstram satisfação por atendê-los antes, durante ou após a aula. A aula do professor $\mathrm{C}$ é tão dinâmica que preciso ficar bem atenta. Embora sempre ultrapasse o horário, os alunos ficam até o final das aulas, que são às sextas-feiras das 19 às 23 horas. $\mathrm{O}$ professor não perde o "pique". Seus alunos do ano anterior, se estão em intervalo de aula vêm para a porta da sala dele e ficam olhando. Saio e eles comentam comigo que têm saudades e que "o entusiasmo dele é incrível". Tem sucesso com os alunos. No intervalo eles sempre o procuram. É ágil, disposto e se envolve com a aula. Não demonstra cansaço, embora tenha mencionado na entrevista que se cansa muito na aula. Também é exigente, por exemplo, quanto à maneira correta de indicação dos problemas e quanto ao uso da terminologia científica quando os alunos explicam algo.

Os alunos percebem, sentem e sabem quando um professor gosta do que faz. "Veja a vibração do professor. Ele até parece uma criança", foi o comentário de uma aluna sobre o professor D, após uma aula em que um experimento deu certo e ficou visualmente interessante. 
Os professores manifestaram que a experiência possibilita perceber, ao longo dos anos e mesmo sem a manifestação oral das dúvidas pelos alunos, se um assunto está acima do seu nível de compreensão ou se o mesmo foi colocado de modo inadequado para o seu entendimento naquele instante. É esta percepção adquirida no tempo e aliada à experiência, que permite sentir pelos olhares e expressões faciais dos alunos se um determinado tópico deve ser recolocado, partindo-se de outras bases. Está, neste aspecto, relacionada com aquilo que Schulman denomina de conhecimento de conteúdo pedagógico, pois só aquele que alia ao conhecimento da matéria, o conhecimento do modo como ensiná-la tem a possibilidade de, naquele instante de dúvida, recolocar-se partindo de novas bases.

A experiência como característica da atividade docente, evidentemente só pode ser observada de modo indireto nas aulas e, inclusive, pelas suas manifestações de criatividade e improviso. Esses dois focos - criatividade e improviso - da categoria características do professor, foram citados nos momentos das entrevistas e, ao se verificar numa tentativa de ampliar a análise - as respostas deles também com relação à categoria planejamento - foco preparação - são percebidos dados interessantes de inter-relação.

$\mathrm{O}$ que quero dizer é que os professores declararam que planejam as disciplinas, preparam cada aula e que ao repetirem o curso para outra turma, tudo é planejado e preparado novamente. Ao mesmo tempo, afirmaram explorar temas não-planejados, dependendo da reação da turma, improvisar mais e melhor, com a prática adquirida e preparar "sentindo a aula, pois enquanto escrevo me imagino, me transporto para lá, criei uma forma de me colocar no lugar" (Prof. C).

Assim, aparecem os aspectos técnicos e intuitivos nas suas exposições sobre o ato de planejar, que reaparecem nítidos quando falam dos focos experiência/intuição e improviso/criatividade, da categoria características do professor, permitindo a inter-relação.

"Quem não tem intuição, também não tem criatividade. Se o professor não tem uma boa intuição, não vai conseguir criar" (Prof. A).

"... a intuição tem um papel, mas a experiência tem muito mais" (Prof. B).

"A intuição é importante para adaptar o seu conhecimento à particular situação do ensino. Os desencontros acontecem porque não se tem a intuição de perceber que embora aquilo seja natural para o professor, não o é para o aluno" (Prof. C). 
"A intuição é uma forma de prever o que acontece com o aluno. Preparar um curso depende de vivência e de certa intuição. Na parte didática, a própria prática já é suficiente" (Prof.D).

“... improviso, experiência, são fundamentais para se tomar uma decisão momentânea. Acho difícil a pessoa que não tem uma boa intuição, ser um bom professor, porque não é só preparar bem a matéria, é preparar a maneira de dar essa matéria e isto depende da intuição. $\mathrm{O}$ aluno quer ver a construção de uma ideia porque para ver só a ideia, ele pega o livro e vê. A intuição é o ato de criar um contexto" (Prof. A).

Nas respostas de dois professores sobre adaptar o conhecimento à particular situação do ensino, saber como traduzi-lo para o aluno, preparar bem a matéria e como a ensinar, desponta a questão tratada por Schulman e relatada por Garcia que é quem resgata essa importância, como já foi mencionado.

"A investigação que Schulman e seus colaboradores
vêm desenvolvendo tem justamente como objectivo
estudar o que sabem os professores sobre os
conteúdos que ensinam, onde e quando adquiriram
esses conteúdos, como e porque se transformam (...) e
como devem ser utilizados no ensino concreto na sala
de aula" (Garcia, in: Nóvoa, 1992a, p.56).

$\mathrm{O}$ aspecto reflexivo como fundamento básico, consciente, de todo o processo, aparece com clareza no objetivo das investigações de Schulman e de seus colaboradores.

Numa história de formação inicial e continuada onde não esteve presente uma preparação pedagógica nem mesmo nos moldes de informação de teorias e modelos - como foi o caso, com exceção de um dos professores, que teve noções pedagógicas sobre a criança e o adolescente - a condição de "reflexão dirigida ao autoconhecimento, de mobilizar a consciência metacognitiva que distingue o desenhador do arquicteto ...", fica, naturalmente, dificultada (Garcia, in: Nóvoa, 1992a, p. 59).

Esse fato, no entanto, não permite desconsiderar o valor da prática docente em questão, mas tentar debruçar-se sobre a conquista do professor em ser um arquiteto (criador) mais do que ser um desenhista (copista). $\mathrm{Na}$ expressão do professor $\mathrm{B}$, "não basta envelhecer na experiência. É importante ter a experiência, mas renovar-se nela". Tal afirmação, feita por um professor, permite olhar com cuidado a colocação de outro ( anotada acima ), de que "na parte didática, a própria prática já é suficiente". Diria que ela é necessária, porém não suficiente. Não se trata de 
aceitar o praticismo, desconsiderando ou menos-valendo o conhecimento pedagógico, a consciência epistemológica da prática.

Ainda com relação ao planejamento do curso, à preparação das aulas e já entrando nos recursos, métodos e técnicas, verifico que os professores da Licenciatura (C e D), declararam preocuparse em voltar sua execução, nas três disciplinas que ministram à especificidade da opção dos alunos. Assim, programam suas aulas de modo a utilizar materiais, recursos e experimentos variados a fim de conseguirem, não só que os alunos aprendam como também conheçam meios diferentes de trabalhar os conteúdos.

As aulas de uma das disciplinas do professor D, são preparadas tendo em vista a utilização do Observatório Astronômico e materiais como: planisfério, gráficos, lunetas, microscópios, globo terrestre, bola de vidro com líquido cor de anil marcando as órbitas celestes, enfim recursos instrucionais variados que ilustram/concretizam os assuntos a serem aprendidos e, posteriormente, ensinados pelos futuros professores, atentos perguntadores. $O$ docente envolve-se com a narração de informações e curiosidades acumuladas ao longo de anos de estudos, leituras e paixão pela Astronomia e, não raro, "perde o fio" da aula.

$\mathrm{Na}$ outra disciplina do professor D (Instrumentação para o Ensino), as aulas são contatos para discussões, decisões conjuntas, preparação e confecção de material como: apostila, experimentos, filme educativo e/ou outros recursos, para um assunto escolhido, que será estudado, preparado e ministrado pelos licenciandos, para alunos da rede pública de ensino, como requisito de Prática de Ensino, ministrada por outro professor.

A disciplina de Física Básica, sob a responsabilidade do professor $\mathrm{C}$, é desenvolvida, com ajuda de um aluno monitor, através de aulas teóricas, mas também com muitas aulas de laboratório, além de filmes, sessões de slides e aulas demonstrativas. Nas aulas teóricas, objetos que se encontram na sala transformam-se em "instrumentos" ( uma régua com orifício e um lápis tornam-se um pêndulo, por exemplo ). Ele tem muito entusiasmo.

Exceto nas aulas de Instrumentação para o Ensino, os professores têm suas anotações em fichas ou caderno e livro-texto sobre a mesa. As aulas são, realmente, preparadas. O professor B, que utiliza livrotexto, comunica aos alunos qual é o que lhe serve de base para o 
desenvolvimento do curso e que os exemplos e exercícios são retirados de lá, "para que eles saibam por onde estudar".

Repetidas vezes, durante as sucessivas aulas a que assisti, observei que os professores se baseiam nas suas anotações, seguem a preparação da aula e interagem com os alunos, possibilitando clima adequado para perguntas e intervenções.

Também constatei que a aula segue um curso normal, sem grandes variações de uma para outra, mas observei que eles a preparam, têm um quadro-negro organizado, são interessados e explicam claramente. Novamente, a exceção é para Instrumentação que tem dinâmica diferente das demais.

Eles desenvolvem o que prepararam, no tempo certo da aula, sem atropelo e sem monotonia. Não se apavoram e não ficam parados. Têm a dimensão do que é preciso e possível realizar, prevendo também, as intervenções dos alunos.

Não deixam perguntas sem respostas, mesmo que tenham que retomar ou antecipar explicações ou ainda, satisfazer curiosidades. Expõem o tempo todo e fazem muitos cálculos. São detalhistas. Em Astronomia e Instrumentação não há cálculos. Na primeira "chovem" perguntas.

Acredito que se guiam pela preparação da aula e por um misto de experiência/intuição. Aproveitam situações do momento para explicar melhor, para ilustrar, para "motivar". Elas não são, no entanto, geradas por meio, por exemplo, do levantamento de repertório do aluno ou de aulas dialogadas em que o professor, consciente e sistematicamente, poderia provocar reflexões repentinas, "tempestade de ideias", respostas breves, cuja exploração poderia formatar aulas mais participativas e interessantes.

As situações são aquelas anotadas em minhas observações e que transcrevo aqui: na sala de aula há uma lâmpada fosforescente com defeito, "piscando" o tempo todo. O professor A explica o que está acontecendo, em termos dos conceitos e fenômenos físicos. Ele também costuma citar exemplos aplicativos na indústria e na vida comum das pessoas.

O professor B ilustra verbalmente algo do conteúdo, relacionando às estrelas e isto dá uma pausa para os alunos voltarem a ficar 
atentos, além de quebrar a inércia que se queria instalar, inclusive em mim. Quando surge uma pergunta sobre algo que não havia preparado, a experiência e o conhecimento obtido lhe garantem a resolução. Observei que aproveita situações do momento para ilustrar melhor.

O professor C utiliza intervenções dos alunos e, também, materiais concretos disponíveis. Já o havia feito com uma borracha escolar e a caderneta de presença. De outra vez, usou um giz e a mesa do professor. Explica determinado conceito utilizando régua e caneta como um pêndulo e os alunos vão propondo exemplos diferentes. Acata as proposições e as desenha na lousa, explicando os fenômenos propostos. Não antecipa e não apressa. Espera que raciocinem e falem. Essas demonstrações improvisadas dão certo e os alunos criam alternativas. Às vezes, por expressão corporal representa o que quer explicar, como por exemplo uma mola, um movimento, uma aceleração. Imagino que fica exausto. Fala aos alunos que "perceber as coisas intuitivamente é importante porque se a pessoa não se sente segura, o aspecto intuitivo ajuda". Sempre que possível faz ligações com o cotidiano, com situações práticas, aplicações, história da ciência, exemplos ilustrativos e observação da natureza, não deixando passar a oportunidade. Observo que segue aquilo que chamou, na entrevista, de sua "regra básica de fazer com que os alunos entendam através da maneira mais natural de falar e melhor sequência do assunto".

O professor D, numa aula de Astronomia, utilizando a luz do retroprojetor, simula o sol incidindo sobre o globo terrestre e faz as explicações quanto à iluminação do hemisfério sul e do hemisfério norte. A luz do retroprojetor foi uma improvisação que deu certo. As aulas de Instrumentação vão acontecendo de uma forma interativa/participativa entre professor e alunos. Ele muda o curso da aula quando é preciso. Guia-se pela intuição e pela experiência, mas parece que mais pela intuição.

Embora as aulas sejam preparadas, o ritmo delas privilegia o entendimento, mais do que o cumprimento do programa, pois como disse um professor, na metade do semestre: "por enquanto vocês precisam entender. Só vou ficar desesperado quando faltar um mês para terminarem as aulas" (Prof. A).

Outro professor $(\mathrm{C})$, como comentou, diminui o ritmo quando necessário, sana as deficiências que percebe e não consegue explorar tudo o que preparou para cada aula. Precisa certificar-se de que os alunos estão entendendo para daí prosseguir. Ele o faz perguntando bastante, esperando a resposta, insistindo para que ela seja dada pelo aluno "com as suas próprias palavras, entendendo o que está dizendo" passa 
exercícios de compreensão que vão tentando resolver enquanto vai andando e olhando atentamente um a um. Se o aluno pergunta, vai convidando ao raciocínio. Ao perceber que está havendo más interpretações, dá o alerta, sem mencionar nomes. Incentiva quem está no caminho certo. Pede para dizer como está raciocinando caso o aluno esteja perdido ou indo por um caminho errado. Se a aula é de laboratório anda o tempo todo pelos grupos.

As temáticas do planejamento de cursos e disciplinas e da preparação de aulas são tão velhas quanto os cursos e as aulas. Suas discussões foram, muitas vezes, encerradas com propostas operacionais de execução contendo formas e fórmulas, traduzidas em manuais de receituários. Surgiram, também, sugestões mais irreverentes do deixar acontecer, não pode planejar, quem planeja é tecnicista e a escola não é fábrica (mas tem todo o jeito!).

Concepções atuais apontam o planejamento como "instrumento de ação educativa". É atividade intencional que busca determinar fins e que explicita valores. Seus aspectos importantes são a participação dos membros envolvidos (ato coletivo), sua realização nos diversos níveis da escola e seu acompanhamento através da avaliação. É instrumento útil no processo de aprendizagem e roteiro dinâmico e flexível para as ações de professores e alunos (Masetto, 1994, p.76-80 ).

Ao buscar identificar as condições facilitadoras da aprendizagem em sala de aula de $3^{-}$grau, Masetto apresenta o planejamento como uma dessas condições, se:

"realizado com a classe, no início do semestre, levando em consideração expectativas, problemas e interesses dos alunos, bem como a especificidade da disciplina, integrando os interesses do grupo-classe: alunos e professor" (in: D’Antola, 1992, p.20).

A definição do conteúdo (outra condição) deve ser: "de interesse dos alunos; útil para os alunos, trazendo o dia-a-dia para a sala de aula, permitindo aplicações práticas do assunto estudado, relacionado com os conhecimentos, com a experiência, com a realidade profissional e com as necessidades dos alunos; busca de solução para os problemas $e$ questões debatidas de forma conjunta entre professor e alunos, trocando suas experiências”. (...) "Inicialmente penosa, é a atividade de planejar que vai dar ao professor informações sobre a eficácia de 
seu trabalho e permitir que seja aperfeiçoado $e$ renovado, além de permitir que se comunique com objetividade com seus alunos e com a comunidade universitária” (Masetto, in: Abreu \& Masetto, 1990, p. 21-22).

Libâneo (1991) destaca a articulação da atividade didática com a problemática do contexto social, que é feita pelo processo de planejamento. Para ele, "o planejamento é uma atividade de reflexão acerca das nossas opções e ações”. Para orientar a tomada de decisões pelos professores quanto ao processo de ensino e aprendizagem, o planejamento tem funções que vão desde a explicitação de diretrizes do trabalho docente em consonância com a participação democrática, até o posicionamento e as ações efetivas realizadas pelo professor na sala de aula, passando pela previsão dos objetivos, conteúdos e estratégias, e culminando na avaliação que afirma ou modifica o trabalho frente às novas situações que ocorrem. Para esse autor,

"a ação docente vai ganhando eficácia na medida em que o professor vai acumulando e enriquecendo experiências ao lidar com situações concretas de ensino. Isso significa que, para planejar, o professor se serve, de um lado, dos conhecimentos do processo didático e das metodologias específicas das matérias $e$, de outro, da sua própria experiência prática”. (Libâneo, 1991, p.225).

Cunha (1994, p.116), afirma que "alguns professores reduzem o planejamento a anotações que fazem previamente às aulas. É claro que há um arcabouço do curso ou da disciplina já apreendido por eles, o que nem sempre é consciente". Concordo com o aspecto não consciente da ação pedagógica e já me referi a ele anteriormente.

A alusão ao que vai sendo apreendido pelos professores, leva a considerar a questão da formação continuada, que já foi tratada neste trabalho sob a ótica de pesquisadores da prática e de teóricos. Essa formação engloba aquisições pessoais e profissionais que se traduzem em aprendizagem em serviço e exemplo pessoal, dois outros focos da categoria das características do professor.

Durante o exercício profissional no decorrer dos anos, ocorrem novas aprendizagens, de tipos variados, motivadas por fatores diversos, que são incorporadas à prática e emergem no convívio que se estabelece numa relação que é profissional, mas é também pessoal, entre 
professores e alunos. O exemplo pessoal refere-se à responsabilidade que o professor sente, verbaliza e demonstra quanto à formação/informação dos alunos.

Ao longo do tempo, no exercício da docência, o professor vai adquirindo um conhecimento que está relacionado à maneira de ensinar. São os exemplos acrescentados, as relações entre conteúdos diversos de uma ou de várias disciplinas permitindo levar os novos conceitos a serem ensinados, ao patamar que possibilita o contato com conceitos já aprendidos, viabilizando novas aquisições de conhecimentos e habilidades. Essa capacidade de como ensinar está estritamente relacionada com a experiência de cada um, exercida de um modo que supõe (re)criação própria e não apenas transmissão/cópia de um livro-texto.

Nas aulas, além dos exemplos já relacionados nos focos intuição e experiência, outras situações observadas podem ser também consideradas como decorrentes da aprendizagem em serviço. Nesse caso entram os exemplos ilustrativos criados para esclarecer um conceito e, o modo como explorá-los visando aprendizagem, o aproveitamento das situações que surgem no decorrer da aula e, ainda, a utilização das intervenções dos alunos, tratados como pessoas buscando o conhecimento e tendo respeitado seu direito de tentar.

Nas entrevistas, perguntados sobre suas aprendizagens no exercício da docência, o aspecto profissional sobressai nas respostas, muito embora o aspecto pessoal seja, também, considerado. No primeiro, são pontos comuns entre os professores A, B e C, por um lado o fato de o professor aprender a ensinar e como ensinar muito mais na prática do que no curso de formação inicial e, por outro lado aprendem as limitações dos alunos e as suas, conquistando mais "maturidade" e "segurança".

$\mathrm{O}$ relato sobre as experiências que deram certo evidencia a importância da aprendizagem continuada:

"... as aulas demonstrativas e o curso de laboratório" em que os alunos "ainda hoje honram o professor porque realmente aprenderam" (Prof. A).

“... nos últimos dez anos o que mais aprendi no trabalho de dar aulas foi exatamente criar capacidade, facilidade de transmitir numa linguagem mais simples" (Prof. B).

"... com o tempo se aprende uma quantidade suficiente de coisas que permitem se não souber numa direção, fazer na outra" (Prof. C). 
O professor $\mathrm{D}$, que acredita na prática como imitação de modelos, considera sua prática "normal", sendo especial sua criação de projetos, destinada "à docência dos outros", pois canaliza seu trabalho primordialmente à extensão voltada ao ensino de primeiro e segundo graus que "é carente de propostas reais e tem que sair da universidade essa interação com a comunidade".

No aspecto pessoal, a opinião comum é a de que no exercício da docência superior se aprende a lidar com seres humanos adultos e "isso é importante para a vida de modo geral", como disse o professor A.

Aprender "psicologia do adulto e teorias pedagógicas por conta própria" a fim de conhecer seus alunos foi decisão tomada pelo professor B, pois embora tenha feito também o curso de Licenciatura, nele aprendeu apenas psicologia da criança e do adolescente. Mesmo assim, considera importante a formação pedagógica, inclusive no Bacharelado.

$\mathrm{O}$ professor $\mathrm{C}$ conquistou sensibilidade para perceber as expressões faciais, segurança para sentir-se bem na frente dos alunos, não temendo as perguntas, e confiança para estar junto com eles e eles com o professor. "Se a classe está junto de você e tem confiança, não há problemas. O professor precisa ganhar segurança própria e confiança dos alunos, pois se as coisas não vão bem é porque não há esses pontos básicos, o contexto já não está bem e não é porque o professor não sabe responder uma ou outra pergunta".

Além da seriedade com que encaram e desempenham seu trabalho - e isso se constitui em exemplo pessoal - está presente nas suas falas e atitudes a preocupação com esse ponto. Ele vem articulado. Não posso dizer que na questão de valores haja um discurso diferente da ação. São coerentes. As discrepâncias que ocorrem são quanto à prática propriamente dita (aspectos técnicos ) ou no fato de não conseguirem total consonância entre o ensino e a pesquisa ou o ensino e a extensão e, então, tornar-se perceptível que as desejam integradas, mas ficam divididos no momento de equacionar o tempo.

Desejo transcrever trechos das suas respostas porque traduzem suas opiniões e caracterizam sua ação:

"Dentro da sala de aula procuro transmitir uma segurança. É importante o aluno aprender a falar com segurança mesmo que ele não saiba. É fundamental em qualquer carreira. Se ele abre a boca tem que ter segurança no que fala. Se ele não tem segurança, não deve falar." (Prof. A). 
"O exemplo é o melhor instrumento porque os alunos não esquecem e se inspiram nisso. Como diz um amigo nosso: "se a palavra convence, o exemplo arrasta". Se o professor tiver atitude de empatia inicial com os alunos, se aproximar, ao terminar a aula conversar com eles do lado de fora, estar ali junto mais um pouquinho, fazer com que sintam que a gente é igual a eles, então você dá um estímulo para que aproveitem isso. É o exemplo. Agora, numa turma que vai se preparar para dar aula, a gente tem não só que fazer isso, mas também chamar a atenção para esses pontos do relacionamento. O professor não tem que dar aula de conteúdo só. Tem que ter conversação a respeito do que é ensinar e o que é aprender. Ir além da técnica e até do exemplo, falando sobre esses assuntos. Isso também no Bacharelado em que, no Brasil, o bacharel poderá vir a ser professor na universidade" (Prof. B ).

O professor $\mathrm{C}$ demonstrou sua preocupação com o fato de que apesar da universidade só conter uma parcela mínima da população com escolaridade de vários anos, não encontrar uma correspondência entre as atitudes tomadas e a educação recebida por essa parcela.

"... me parece que a universidade forma as pessoas do ponto de vista técnico, mas não educando-as" (Prof. C).

"No exterior, numa universidade moderna, se você sair, colocam outra pessoa no posto e continua do mesmo jeito. Na universidade, no Brasil, é essencial o seu trabalho" (Prof. D).

Observei nas aulas do professor B (que se referiu ao exemplo que deve ser para os próprios alunos), que realmente é bem próximo deles, é paciente e seguro, entusiasmado, valoriza a interação entre os alunos e leva a docência a sério. Nunca faltou, adiou, cancelou aulas. Nunca se atrasou e nem terminou a aula antes do horário. Percebi que não tinha pressa, pois muitas vezes os alunos ficavam para "bater um papinho" com ele. Eu mesma gostava muito de ouvir suas opiniões sobre os alunos, a docência, a Física. As entrevistas com ele foram bons aprendizados. Ao final da primeira, por exemplo, anotei nos meus apontamentos: "classifico essa entrevista como uma lição de vida e como uma verdadeira aula de mestre, de educador". Além disso, anotei que me lembrei naquele momento do que havia lido sobre a linguagem que aproxima o professor do aluno ${ }^{65} \mathrm{e}$ de que me havia questionado sobre ela não no que se refere ao alfabetizar ou lecionar Língua Portuguesa/Literatura, mas na situação das ciências ditas exatas. As respostas do professor no sentido de descer ao nível do aluno e crescer com ele, não esquecer nunca como se era quando aluno, que tipo de dúvidas e inseguranças sentia, como gostaria que o professor fosse e

65FREIRE, P. e SHOR, I. - Medo e Ousadia: o cotidiano do professor. Rio: Paz e Terra, 1986. 
ensinasse, enfim o colocar-se na "pele" do aluno sempre, significa falar sua língua e ter a mesma linguagem.

$\mathrm{O}$ professor $\mathrm{C}$ pauta suas atitudes por valores nos quais acredita e considera ideais. É atencioso para com os alunos e tem uma interação satisfatória com eles - mesmo fora da sala de aula -, transmite entusiasmo, valoriza a contribuição do aluno e em nenhuma das aulas pude observar alguma expressão que denunciasse zanga, impaciência ou cansaço, por mais insistentes fossem as observações dos alunos.

O professor $\mathrm{D}$, que acredita no trabalho como a força motriz, é empreendedor e coordena projetos de atuação de alunos e atualização de professores.

Algumas vezes, enquanto os ouvia e observava, eu me perguntava se teria havido algum professor cuja influência tivesse sido determinante nas suas condutas profissionais e pessoais.

O foco modelo de professor, ainda da categoria características do professor, foi introduzido com o propósito de detectar se os professores se inspiram num modelo que tiveram e que os conquistou, até que ponto isto ocorreu e quanto da conscientização desse fato eles mantêm. Essa possível inspiração começa com a imitação da atuação do professor-modelo e vai se diluindo no decorrer do acúmulo de experiências docentes.

Essa questão foi espontaneamente abordada por um deles, no decorrer da entrevista ao afirmar que "todo aquele que vai dar aula pelas primeiras vezes, se inspira em algum professor que admira. Todos nós somos assim na vida diária. Se vamos fazer algo pela primeira vez e já vimos alguém, procuramos imitar. Isso, é claro, se aquela pessoa realmente ganhou a gente. É o exemplo" (Prof. B).

Já outro, apesar de admirar um professor do seu curso secundário, afirmou não gostar de ministrar aulas expositivas, dizendo: "Fui aluno do Mário Tolentino e uma aula como a dele eu não sei dar. Algumas pessoas têm o dom do discurso na frente da lousa. Eu não tenho e procuro fugir disso" ( Prof. D ).

O professor B teve na sua formação inicial "professores muito dedicados, aprendendo muito com eles. (...) Tive teorias pedagógicas para me ajudar". Relatou que já no primeiro ano, como estudante, teve "a felicidade de trabalhar com um professor que gostava de ensinar, que era 
dedicado, e isso me cativou". O modelo de professor que gosta de ensinar e se dedica foi forte a ponto de fazer o então estudante de Engenharia passar para o curso de Física e tomar a resolução de que seria professor universitário. Passados 25 anos, o modelo de professor que teve ainda está presente. Em outro momento da conversa, citou que pôde "conviver com pessoas como o professor Pierre Lucie, que se dedicou ao ensino de Física na universidade, a melhorar a qualidade do ensino. Sua formação era da universidade francesa. Procurava dar aula de Física sempre fazendo muita analogia com geometria, mostrando os resultados físicos mais graficamente, e aquilo ajudava os alunos a aprenderem". Ainda hoje segue o mestre, ao procurar "trazer exemplos que possam estar mais próximos dos alunos, para que eles tenham uma compreensão melhor".

Os professores tiveram algum tipo de experiência no ensino antes mesmo de se tornarem docentes universitários. Foi um ponto concordante, nos quatro, a consideração quanto à importância de experiências anteriores, o que motivou a inclusão desta categoria. Apregoam a importância de que futuros professores sejam, antes, monitores. Assim, esse foco de análise - monitor - foi incluído, entendendo-se aqui como monitor aquele aluno que ministra aulas sob orientação de um docente. Sua função não é, apenas, auxiliar o professor esclarecendo dúvidas dos alunos (embora possa, também, fazê-lo).

Monitor é usualmente entendido como o aluno que colabora com o professor nas correções de exercícios, podendo, também atender alunos para dirimir suas dúvidas. Entretanto, considerando que, em anos anteriores a 1992, no Instituto de Física, àquelas atividades foi acrescentada a responsabilidade de algumas aulas sob a supervisão do professor responsável, o trabalho de monitoria foi entendido como uma possibilidade do exercício docente durante o curso de pós-graduação.

$\mathrm{O}$ professor $\mathrm{C}$, por exemplo, relatou ter sido monitor no Instituto, por ocasião da pós-graduação, dando aulas, e entende ser esse um dos motivos que o colocaram na atividade docente. "Fui monitor de três disciplinas, quando estava no mestrado e no doutorado. Isso foi muito importante porque eu dava aula mesmo. Foram essas monitorias que me levaram a ser professor porque os alunos fizeram abaixo-assinado para eu ser contratado. Por isso é que eu sou professor." Ele colocou uma importância adicional a essa sua experiência, pela facilidade de interação com os alunos-colegas naquela oportunidade. "Acho que foi um bom começo porque não tem a mesma responsabilidade do professor, no sentido de que sendo ainda aluno, você está junto com eles, são mais ou menos colegas e é um degrau menor para transpor do que já ser direto professor." 
Isso foi significativo também porque aprendeu a "sempre manter um relacionamento o mais próximo possível dos alunos". Àqueles que poderão vir a ser professores aconselha a participação. "Tem cursos na pósgraduação com seminários e muda muito o fato de um dia ter que expor na frente dos colegas, porque vai criando ambiente. Uns vão lá e falam de qualquer jeito. Para eles não mudou nada. Outros têm uma grande preocupação em fazer correto e isso leva o sujeito a ter aprendizado".

O professor B relatou que, ainda no primeiro ano do curso universitário, trabalhou com um professor na preparação de uma bateria de experimentos, testagem deles e montagem do laboratório do Instituto de Física da universidade onde estudou. No ano seguinte foi monitor, como resultado desse trabalho, porque havia participado de todo o processo, trabalhado com afinco no laboratório, gostava disso e conhecia bem todas as experiências. "Então comecei a minha experiência de trabalhar com alunos sendo monitor". Dois pontos foram favoráveis: aprendeu com um professor que gostava de ensinar e sentiu-se "realizado naquele trabalho de passar o que tinha aprendido".

O professor A, durante os dois cursos de graduação que fez em duas universidades públicas de São Carlos, foi professor no segundo grau, em dois colégios particulares. "Com isso você vai adquirindo a prática de ensino, fazendo. A prática de ensino consiste em perceber qual é o nível da classe e qual é a estratégia que se deve usar para trazer os alunos ao nível do curso. É preciso dar chance para eles ensinarem antes de concluir sua formação. Ter curso de prática de ensino é importante para a pessoa aprender, se ela não sabe, quais são os fatores gerais que determinam o ensino, mas na prática a teoria é um pouco diferente. Aprender as experiências que alguém já teve é bom, mas ter as suas próprias é fundamental". Perguntado sobre o Programa de Aperfeiçoamento do Ensino (PAE) para alunos da pós - graduação, disse achá-lo "fundamental porque tem aluno com uma capacidade didática que muitos professores não têm e o professor quando vai ficando mais velho, passa a preocupar-se com o poder ou com a administração ou com a pesquisa em demasia, distanciando-se do ensino. A figura do monitor existe em todo lugar do mundo. Devia ter bolsas para as pessoas ensinarem e fazerem pesquisa ao mesmo tempo, porque é preciso cuidar da carreira profissional. É o chamado T.A." (Teaching Assistant).

O professor $\mathrm{D}$, que coordena projetos de apoio ao ensino de $1^{\circ}$ e $2^{\underline{o}}$ graus, oferece oportunidade a alunos universitários de atuarem como monitores. Enfatiza essa atividade, destacando que: "uma vez, num curso de pós-graduação, os alunos apresentaram seminários. Havia monitores do 
CDCC que eram alunos. A diferença foi assim de saltar aos olhos, embora eles não fossem os melhores do curso. Na hora dos seminários, eles brilharam. Para o aluno, esta é uma vivência muito importante. Depois, na vida prática, a capacidade de se expressar tem um peso muito grande e a nossa graduação não estimula isso". Para alunos do Bacharelado que poderão vir a ser professores, ele diz: "eu tenho uma receita pronta: serem monitores. Tenho uma reportagem feita pela Escola Viva, da RTC, que entrevistou um monitor de Matemática. Ele é aluno da Engenharia e disse que a única oportunidade de praticar é essa. Teve um tempo em que esses alunos eram monitores em uma disciplina de pós-graduação".

Ao mesmo tempo, esse professor defende que "no $3^{\underline{0}}$ grau não adianta colocar regras didáticas de como faz isso, como faz aquilo. Tem muitas pessoas que têm boa prática e possibilitam que um aprenda com outro ... Como na época medieval, do artesão que aprendia fazer sapato com outro que já sabia. É aprender fazendo. A prática docente funciona assim: pegar os melhores professores e aprender com eles. A boa aula devia fazer da pessoa um ídolo para que outros pudessem imitá-lo". Há que se considerar que ele faz referência a duas situações: a daquele que aprende por ver e imitar simplesmente e a daquele que aprende no exercício, aprende fazendo. Quem imita e permanece imitando, reproduz e é estagnado. Se adotar a postura reflexiva e de tomada de consciência, poderá, no decorrer do seu fazer, ir modificando aquela prática linear e que não supõe a descoberta e construção do conhecimento.

Interessante observar, também, que o professor A define o que é prática de ensino e o professor $\mathrm{D}$ diz como a prática docente funciona, embora a formação inicial de ambos seja em ciências exatas. Fazem uma redução de senso comum sobre o que é ensinar e aprender. $\mathrm{O}$ primeiro tece, ainda, um comentário equivocado sobre a linha de pesquisa denominada Ensino de Física e sobre a Pedagogia, ao afirmar que "é difícil ensinar Física se você não sabe Física. As pessoas que fazem pesquisa em ensino têm que tomar cuidado. Podem estar fazendo pesquisa em Pedagogia que é outra coisa ... respeitável, necessária, mas não é ensino de Física porque ensino de Física é ensinar Física. Como ensinar física é Pedagogia”.

"Aos estudantes de pós-graduação, na sua maioria futuros mestres universitários, são dadas poucas oportunidades para a aquisição de alguma formação em educação, que possa contribuir tanto no exercício do magistério, quanto na percepção de como 
construir uma interação entre o saber científico e sua veiculação ao aprendiz”.

Com esta justificativa são apresentados os resultados de quatro anos de aplicação de uma experiência em prática de ensino de Química no $3^{\underline{0}}$ grau, em que os alunos estagiam numa disciplina de graduação com a incumbência da

"proposição de uma atividade de ensino, planejandoa em todos os aspectos cabíveis, aplicando-a, total ou parcialmente, em situação de ensino-aprendizagem e avaliando o resultado junto aos alunos que participaram da atividade”. Os resultados apontam para a "incorporação de vários aspectos metodológicos discutidos (...), segurança ao propor inovações (...) e mudança de postura em relação às atitudes críticas que assumem, percebendo-se que passam a ter uma reflexão mais ampla e aprofundada de problemas educacionais e da Ciência que praticam” (Felicíssimo et al., 1991, p.122-24).

Por outro lado, para superar a questão da falta de conhecimento pedagógico no ensino de $3^{\underline{0}}$ grau, iniciativas vêm sendo tomadas, tanto por parte de órgãos governamentais como por parte das instituições. É o caso, por exemplo, das disciplinas de Metodologia do Ensino Superior nos cursos de especialização que objetivam formar professores para o $3^{-}$grau (Portaria CFE $n^{0}$ 12/83). A inserção dessas disciplinas em cursos de mestrado e doutorado e os serviços de apoio pedagógico, existentes em várias universidades, visam oferecer suporte à docência do ensino superior.

A monitoria foi colocada por Chagas e outros 66 , como um recurso a ser utilizado pelo professor na melhoria do aprendizado do aluno. Não implica em sofisticação, nem modificações na estrutura do ensino e está de acordo com nossa realidade educacional. Aponta que seus resultados são bons e "objetiva diminuir ou minimizar os problemas de aprendizagem, atenuando as dificuldades apresentadas pelos alunos”. O monitor é um aluno que já cursou a disciplina - geralmente com êxito - e por estar próximo tanto do professor quanto de seus colegas, torna mais facilitado o intercâmbio de informações e a aprendizagem dos alunos. Poderá favorecer a interação professor-aluno, além de

"programar atividades de recuperação para atender às dificuldades surgidas com relação aos pré-

${ }^{66}$ Nesse artigo a monitoria é entendida no sentido tradicional, isto é, o aluno não ministra aulas. 
requisitos necessários ao aprendizado da disciplina, orientar os colegas em suas dificuldades específicas, avaliar-lhes o desempenho, verificar o nivel de domínio de conteúdo, possibilitar-lhes a revisão de tópicos que ainda apresentam dificuldades e preparálos para avaliações do professor" (Chagas et al., 1985, p.32).

Em quase todas as grandes universidades norte-americanas, existem programas que envolvem alunos do doutorado em atividades junto aos estudantes no início da graduação, principalmente quando eles formam um grande número - o Teaching Assistant. Geralmente o Teaching Assistant fica encarregado de coordenar aulas adicionais para um sub-grupo de alunos de um professor, bem como se incumbe da correção das provas e dos trabalhos dos estudantes além de dedicar algumas horas semanais ao atendimento individualizado. Suas atividades como T.A. são avaliadas pelos estudantes e pela universidade e o desempenho é considerado nas contratações dos futuros professores ${ }^{67}$. O programa tem, portanto, dupla finalidade: uma primeira que é proporcionar um atendimento a pequenos grupos de alunos, suprindo a impossibilidade do professor da disciplina; uma segunda, que é treinar os alunos de pós-graduação como professores. Entre as vantagens do uso dos Teaching Assistant está, também, a facilidade de proporcionar maior interação, com componentes de motivação, já que eles são também estudantes. Entretanto, falta de conhecimento pedagógico e de habilidades para o ensino podem anular uma das vantagens que é a da instrução para pequenos grupos de alunos ${ }^{68}$.

Em 1992, a USP instituiu o Programa de Iniciação ao Ensino Superior, que em 1994 passou a chamar-se Programa de Aperfeiçoamento de Ensino. A insistência em mencioná-lo deve-se ao interesse pela capacitação docente no âmbito mais amplo e, na limitação deste trabalho, em provocar a discussão para o que deveria e poderia uma instituição que sempre privilegiou a pesquisa, oferecer quanto às condições mais satisfatórias no ensino, além de passar a valorizar adequada e realmente uma atividade essencial no tripé que sustenta a existência da universidade. Tal iniciativa reflete preocupação institucional real com a docência? Significa que o ensino vai ser avaliado, nos mesmos parâmetros exigentes da avaliação que é feita na produção científica? Tal avaliação vai considerar a voz e o voto dos alunos - os principais usufrutuários -, dos

${ }^{67}$ Ruffino, M.A. - Teaching Assistant, in: Boletim do Programa de Aperfeiçoamento de Ensino USP, São Paulo, nº 4, Abril/96.

${ }^{68}$ Lawrenz, F. et al. - Training the Teaching Assistant, JCST, November, 1992. 
próprios estagiários, dos supervisores (professores responsáveis pelo estágio), além dos pró-reitores, diretores e chefes?

Nos boletins divulgados até o momento há, nos editoriais, o convite à responsabilidade dos envolvidos e ao necessário aperfeiçoamento da comunicação entre todos. ${ }^{69}$

Há, ainda, depoimentos de professores e estagiários que apresentam suas opiniões, experiências realizadas e resultados obtidos. Dois relatos publicados nos boletins e trecho de um relatório encaminhado chamaram minha atenção porque ressaltam a importância que tem também a preparação pedagógica, na universidade. São eles:

"Tenho aproveitado muito essa oportunidade, especialmente porque ela me possibilitou desenvolver a habilidade didática que falta, muitas vezes, às pessoas que se dedicam somente a trabalhos profissionais e de laboratório, como era o meи caso. Noto que os alunos, tendo a assistência de um outro colega, têm oportunidade de discutir assuntos tratados em sala de aula ..." (Povinelli, S.C.S. EESC) ${ }^{70}$.

"Até há pouco tempo atrás, o aluno de pósgraduação da USP ressentia-se de um programa que visasse à complementação de sua formação, enquanto futuro docente, e que possibilitasse a experiência didática tão exigida e necessária nas seleções para professores universitários. O PAE veio preencher essa lacuna, possibilitando o contato direto com as atividades pedagógicas, sob a supervisão de um professor, o que permite uma avaliação crítica mais rica das situações professor/aluno $e$ ensino/aprendizagem" (Baldochi, V. - EESC) ${ }^{71}$.

"Em minha opinião, o PAE, se trabalhado dentro das suas propostas, proporciona aos alunos de pósgraduação, a oportunidade de interagir, adquirir experiência e vivência em relação à docência e isso é

5KRASILCHIK, M. Editorial dos Boletins do PAE. São Paulo : USP, agosto e dezembro/95.

70 In: PAE - Boletim do Programa de Aperfeiçoamento de Ensino. São Paulo: USP, n.3, dez. 1995.

${ }^{71}$ In: PAE - Boletim do Programa de Aperfeiçoamento de Ensino. São Paulo: USP, n.3, dez.1995. 
essencial principalmente para aqueles que almejam o magistério superior" (Cione, A.P.P. - IQSC) ${ }^{72}$.

Algumas categorias e seus focos de análise referem-se explicitamente à sala de aula. Neste sentido, embora tenham se constituído em questões feitas separadamente aos professores e também tenham sido descritas uma a uma na Metodologia, serão analisadas, tanto quanto possível, numa tentativa de articulá-las e explorar da melhor maneira as contribuições dos professores. São as seguintes categorias: Execução, Interação, Docência e Avaliação, analisadas segundo seus focos: aula; recursos, métodos e técnicas; livro-texto; interação professor-aluno; concepção sobre o aluno; concepção de ensino; concepção de aprendizagem; concepção de avaliação. O eixo central é a interação professor-aluno, em torno da qual giram os demais aspectos.

A interação professor-aluno e aluno-aluno é encarada como aspecto importante na dinâmica da sala de aula por alunos e por pesquisadores do ensino.

Esta dinâmica pode ser mais tranquila, produtiva e positiva ou mais conflituosa e problemática dependendo de vários fatores, entre eles a relação dos seus membros.

No tipo de relacionamento - mais formal ou informal - que se estabelece, está implícita a opção pedagógica do professor e o direcionamento que imprime à sua prática docente.

Tem sido suposto e é quase senso comum entre professores, que nas classes das crianças e adolescentes o professor precisa, necessariamente, estabelecer uma interação bastante afetiva e próxima com os alunos, prescindindo - e aí se vai para o extremo oposto - de toda e qualquer preocupação neste sentido quando se trata de alunos adultos, principalmente universitários.

Dois pontos precisam ser considerados do ponto de vista pedagógico: um primeiro é a questão da relação que leve à autonomia ou que leve à submissão, e o segundo é que, para os alunos, uma interação satisfatória é importante em qualquer nível da escolaridade e em todos os cursos ou áreas do conhecimento.

72 Trecho transcrito do Relatório encaminhado pela estagiária de Psicologia da Educação, do Programa de Aperfeiçoamento de Ensino à Diretoria do IFSC. 
O professor é o mediador entre o conhecimento e o aluno. Ele tem sido visto como a figura central no processo de ensino e aprendizagem. Esta expectativa social em torno do seu papel condiciona seu comportamento e o faz desenvolver - conscientemente ou não intencionalidades e direcionamentos cujo ponto de referência são as suas concepções, valores e aprendizados.

Sem pretender discutir o "bem" ou "mal" desse fato, sabemos que o professor seleciona, decide e dirige e, ao fazê-lo, impregna sua atuação com seu "eu" racional, mas também sensorial e emocional. Poderia dizer que exterioriza sua vida pessoal e profissional àqueles que compartilham da vivência da sala de aula.

O professor, muitas vezes, se amedronta diante da possibilidade de se colocar por inteiro na docência. Dentro dele "brigam" as cristalizações do acadêmico, com as suas convicções, e ele tende a sufocar essas últimas.

Os alunos, de modo geral, consideram a interação importante. Cunha (1994) afirma que "as justificativas dadas pelos alunos para escolha do Bom Professor estão bastante dirigidas para as questões atinentes à relação professor-aluno" (p.69). São alunos de $2^{\circ}$ e $3^{\circ}$ graus. Eles apontam o conhecimento da matéria, mas enfatizam o aspecto relacional. Para a autora, "a relação professor-aluno passa pelo trato do conteúdo de ensino" (p.71), ou seja, as atitudes dos professores que estabeleceram um relacionamento mais próximo mesclam-se com suas habilidades de ensino, não significando que boas relações incluam "professor bonzinho", ou comportamento paternalista.

O que observei foi o fato da relação professor-aluno e da concepção sobre o aluno, não só passarem "pelo trato do conteúdo", como ainda ser colocada ênfase no ensino e na figura do professor como pontos centrais para os quais convergem suas opiniões e ações em se tratando da interação, do ensino, da aprendizagem, enfim da concepção de docência.

Nos docentes investigados, a interação é um meio para o aluno perguntar, ouvir/responder questões e o professor saber mantê-los atentos. A finalidade é o professor poder "transmitir o que quer", "tirar dúvidas", "produzir", ou seja, ensinar. Os aspectos psicológicos da interação não estão descartados: "o aluno tem que se sentir bem para fazer determinadas intervenções"; "a interação tem que ser na base do diálogo, pois se o aluno tem medo cria bloqueio psicológico"; "sempre tentei manter um relacionamento mais próximo dos alunos, dou muita liberdade para se colocarem e insisto muito para que venham à minha sala tirar dúvidas"; 
"procuro ao máximo trabalhar de forma interativa, ouvi-los o tempo todo, o que é mais fácil quando o número de alunos é menor". O objetivo é, inquestionavelmente, conseguir ensinar.

No caso do professor B, que fez Licenciatura na graduação, estão presentes qualidades de compreensão, respeito pelos sentimentos e proximidade, pois afirma que "cada aluno é um mundo de experiências próprias que precisa ser considerado"; "não deixo darem risada de quem faz uma pergunta que os outros acham simples e pergunto aos que riem se sabem responder"; "o professor não pode representar-se num pedestal". A fala é confirmada pela sua prática, pois valoriza as contribuições e os alunos o retém depois da aula para trocar ideias.

No decorrer das aulas dos quatro professores estudados, os alunos perguntavam sempre que tinham dúvidas. A forma de responder apresentava nuances pessoais. Um dos professores demonstrava gostar de que perguntassem e insistissem, inclusive depois da aula ( Prof. B ). Outro se empolgava tanto nas explicações, ilustrando com vários comentários, que, não raro, "se perdia" ( Prof. D ). O outro recebia, todos os dias, alguns alunos em sua sala e os atendia prontamente ( Prof. C ).

Com o professor A, ocorre uma interação de dependência, de controle direto e a ordem do pensamento é imposta. "Para transmitir o que quer, tem que saber prender a atenção dos alunos, perguntando ao invés de esperá-los perguntar já que o objetivo é relocalizá-los na aula e não esperar que tirem suas conclusões nem que redescubram um tema", repetia várias vezes. Essa interação é o sinônimo de acompanhar, olhar para o professor, ficar atento e não necessariamente estar em participação ativa e parceira.

A convicção de que o medo cria bloqueio psicológico, de não poder representar-se num pedestal, que os alunos não são iguais e que "um ponto fundamental para a construção da melhoria da qualidade de um docente é o intercâmbio com os alunos, a conversa aberta com eles", estabelece entre professor e aluno uma forma de interação que encaminha ambos para a autonomia ( Prof. B ).

Para o professor D, estar muito receptivo encerra "perigo porque os alunos podem querer influenciar muito na aula". Apesar de afirmar que "a interação depende dos objetivos e das condições do curso, do número de alunos e se é curso teórico ou experimental", em suas aulas, nas duas disciplinas, ouvia bastante os alunos. A fórmula verbalizada tinha, na 
ação, a flexibilidade necessária, pois considerava igualmente as intervenções dos alunos do primeiro e do último ano.

Nas aulas, as interações são na quase totalidade, referentes ao conteúdo, mas ocorrem, também, contatos mais informais.

No capítulo sobre o referencial teórico, destaquei que Abreu \& Masetto (1990), Cunha (1994), Godoy (1992), Grígoli (1990), Mosquera (1976), e outros, fazem referência à importância que alunos e docentes atribuem à interação. Grígoli, por exemplo, cita-a como um dos atributos do professor na sala de aula. É a dimensão interpessoal do relacionamento. Ela é mediadora da qualidade da prática docente e numa perspectiva democrática e não romântica preside o processo educacional.

Não diria que a interação observada nos docentes do meu estudo tem a conotação do modelo romântico de ensino, mas também não a posso chamar de democrática no sentido amplo do termo. Trata-se de uma forma de interação, voltada para a preocupação com o ensino, predominantemente relacionada ao modo de agir do professor e secundariamente dependente do comportamento dos alunos. Esse modo de agir do professor é circunscrito à concepção sobre seu papel no processo de ensino e aprendizagem e traduz seus padrões e valores (Abreu \& Masetto, 1990, p.115). Reflete-se, também, na execução da aula.

Essa execução da aula, entendida como "ter didática" - que poderia ser chamada de manejo de sala de aula - e que se configura no "fazer uma boa lousa", "usar recursos audiovisuais" (transparências), "demonstrar os exemplos", "calcular", "não extrapolar o tempo", é valorizada por alunos das áreas exatas que juntamente com os professores, opõem resistência às mudanças. Segundo D’Antola, “com exceção da aula tradicional, as demais abordagens dificilmente são encontradas em nossa realidade” (1992, p.48).

É a abordagem em que o professor "dá aula" (Cavaco, in: Nóvoa, 1991, p.166). Dar aula ou passar o conteúdo é pressupor a transmissão de algo definitivo. Uma concepção moderna de ensino deveria coerentemente levar à expressão "fazer uma aula", entendido esse fazer como uma construção em que os membros envolvidos - professor e alunos participam, descobrindo/aprendendo o conteúdo e também a forma de ensiná-lo/aprendê-lo.

Garcia, citando Schulman, apresenta essa combinação entre o conhecimento da matéria e o conhecimento do modo de a ensinar, como 
sendo "o conhecimento de maior interesse do ponto de vista didáctico: o conhecimento de conteúdo pedagógico” (in: Nóvoa, 1992a, p.57).

Ele enfatiza que o conhecimento de conteúdo pedagógico compreende "as formas mais úteis de representação das ideias, as analogias mais importantes, ilustrações, exemplos, explicações e demonstrações (...)” (p.57). Em outras palavras, compreende a síntese motivadora do professor.

No entanto, de modo geral, para os professores são os alunos que devem sempre estar motivados. Não fazem referência à postura que deve ter o professor. Tem sido suposto, quase por definição, que os docentes são motivados, assim como $\underline{\text { são }}$ criativos. No ato pedagógico como intercâmbio de saberes e vivências, professor e aluno são importantes no processo porque são co-participantes nas mesmas finalidades. Evidentemente há funções mais específicas dos professores e outras mais dos alunos.

Tenho ouvido com muita frequência, por parte de docentes e alunos, frases do tipo: "os alunos são desmotivados", "os professores não têm motivação", "a aula não foi motivada" e outras expressões similares. Parece-me que, de modo geral, nas áreas científico-tecnológicas, a motivação é entendida como algo que vem de fora para dentro, que para ser conquistada ou desenvolvida é trabalho de "mão única", dependente do esforço de um só (o aluno), que é algo que todos os docentes gostariam de que os alunos tivessem e vice-versa, como também todos gostariam de ter, mas só alguns (iluminados?) têm.

Um dos professores insistia amiúde que "durante a aula, o objetivo é o aluno entender e as oportunidades de raciocinar não serão nesse momento, mas através de listas de exercícios ou temas para pensar em casa" (Prof. A). Por achar difícil o aluno entender sem raciocinar, perguntei-lhe como sabia que estavam entendendo. A resposta foi que percebia pelas "respostas deles, pela expressão e pela maneira como respondem a um estímulo do professor". O aluno não participa, portanto, do seu processo de conhecimento. Com relação aos recursos, métodos e técnicas, e livro-texto, afirmou sua preferência pela aula demonstrativa, modalidade que utilizou uma vez, em outra disciplina. Utiliza lousa e giz e esporadicamente transparências. Não segue um livro-texto, preferindo escrever seus próprios textos. Disse que "o livro-texto é a biblioteca". 
O professor B gosta de ter um livro-texto "para o aluno saber onde buscar e não se dispersar". Considera que "recursos são acessórios para ajudar a fixar". Ele qualifica seu curso como "standard".

O professor $\mathrm{C}$ considera a aula como "aquele momento em que tudo é estranho ...". O conteúdo não o é para o docente, embora seja para o aluno. Portanto, entendo que a situação de proximidade e interação que, mesmo familiar, é estranha num primeiro momento (que se renova a cada aula), causa, muito mais que o conteúdo, este sentimento que leva à inquietude e curiosidade.

O mesmo professor havia dito que, ao preparar as aulas, procura imaginar-se lá, tentando, então, cercar as possibilidades de interferência ou de situações problemáticas por ocasião da execução do que preparou. Entretanto, a aula é um ambiente que comporta situações com uma certa imprevisibilidade. Uma pergunta de um aluno pode alterar o encaminhamento do que foi programado. O professor vê essa situação com um certo grau de insegurança por possibilitar possível fuga das situações planejadas. Argumentou que a pergunta pode, por um lado, suscitar um aspecto não previsto pelo professor, levando-o a situações difíceis e, de outro lado, pode ser instrumento, intencional ou não do aluno, que perturba $\mathrm{o}$ andamento do planejado.

Durante o semestre, além de lousa e giz, este professor utilizou transparências, filmes, slides e experimentos. Na entrevista justificou a não utilização de livro-texto na sua disciplina pela inexistência de um que seja adequado à Licenciatura, já que os livros são mais dirigidos ao Bacharelado.

O outro professor da Licenciatura afirmou "que a única forma de dar aula é observando a expressão facial dos alunos" ( Prof. D ). Perguntado sobre o que faz se o aluno sugere uma pista diferente do que havia planejado, o professor respondeu que sua "tendência é perder o fio, com o diálogo". "As coisas bonitas, ideais, a gente deve fazer com muito bom senso e essa é a coisa que mais aprendi no começo da carreira. $\mathrm{Na}$ Europa não há preocupação com interação e na Alemanha as aulas são totalmente anônimas. No Brasil a gente é mais mãe, se preocupa ...”. Ao mesmo tempo faz afirmações no sentido de que o diálogo, o ouvir, representam perigos. Contrapõe diálogo e disciplina, como também interesse e aula sem linha. Recomenda bom senso e cuidado com as "coisas bonitas" da docência e da interação com os alunos. Nas aulas utiliza transparências, slides, experimentos e recursos instrucionais variados, disponíveis no Observatório Astronômico e no CDCC. 
Percebe-se que realmente a aula é o ponto máximo da docência e lhe é atribuído um papel importante $\mathrm{O}$ professor é o centro do processo de ensino e aprendizagem, sendo a aula a sua expressão. As aulas, dirigidas e diretivas, são expositivas e têm bastante cálculo. O professor D, pela própria natureza das disciplinas, não precisa calcular e ele não é diretivo. Outros traços comuns aos três primeiros são a preocupação com a lousa organizada, com a coerência e clareza na exposição dos conteúdos, com a resolução detalhada dos exemplos e dos exercícios, com a relação entre o assunto e a história da ciência e com a citação de onde os problemas podem ser aplicados. O professor $\mathrm{C}$, pelo fato de seus alunos estarem em início de curso e não poder utilizar uma matemática mais sofisticada, pois não a adquiriram ainda, desenvolve formas menos elaboradas dessa ciência para fazê-los compreender os conceitos.

Como três dos professores (A, B e C) estão envolvidos com a pesquisa, apresentei-lhes, nas entrevistas, uma situação em que o trabalho docente é comparado a outra atividade familiar a eles, qual seja a de produção de artigos científicos. Suas respostas, como eu já esperava, caminharam no sentido de destacar o senso de responsabilidade que deve estar presente tanto na redação de um paper como na prática docente. Entretanto, pude detectar que a necessária clareza e concisão de um trabalho científico é transladada para a situação de aula. Por exemplo, para o professor C "normalmente quando alguém escreve trabalhos, toma cuidados com a apresentação e redação para ser entendido. Se o professor pensar desta forma ao dar aula, vai preocupar-se com o entendimento pelos alunos, com a melhor maneira de falar e a melhor sequência para colocar o assunto. Estas são regras básicas. Quando preparo aula, tento me colocar no momento da aula e me pergunto qual a maneira mais natural para quem está ouvindo pela primeira vez".

O professor B acrescentou que assim como é julgado um trabalho científico os alunos também julgam a aula do professor. "Ao escrever um trabalho científico é preciso clareza, precisão e concisão, além de mostrar o que foi feito, que contribuição está sendo dada e que tipo de discussão aquilo pode suscitar. Se o professor preparar uma aula com esse espírito, certamente vai atingir um objetivo que se pretende de clareza no ensino. Na docência, nossos árbitros são os alunos. Se gostam da aula, ficam. Se não gostam, vão embora. Eles são fiéis julgadores" ( Prof. B ).

$\mathrm{Na}$ execução das aulas há uma semelhança maior, principalmente, entre o professor $\mathrm{B}$ e o professor C. Talvez não seja possível encontrar pontos mais concordantes entre os dois da Licenciatura 
(C e D), no que diz respeito à execução das aulas, porque a disciplina do primeiro é básica enquanto que as outras duas são: mais informativa do que formativa (Astronomia), e aplicativa para o ensino (Instrumentação).

Nas observações das aulas, verifico que os professores realmente são o centro do processo e tudo gira em torno da dinâmica que eles imprimem.

As aulas do professor A, não são "paradas". Ele é dinâmico e irrequieto, fala o tempo todo, faz trocadilhos e brincadeiras com as próprias noções de Física e ri junto com os alunos, faz mais questões do que as recebe, responde todas as perguntas, anda pela sala e aproxima-se dos alunos, olha-os, procura não ficar de costas para eles ao escrever as resoluções na lousa, que, aliás, é sempre organizada, fala mais do que escreve, faz o resgate histórico do assunto, dá exemplos aplicativos na indústria e na vida comum das pessoas, coloca suas opiniões com firmeza, mesmo sem total certeza, para que os alunos aprendam a ser seguros, conforme disse em uma das entrevistas. Os assuntos são difíceis e preparatórios para disciplinas mais complexas. No início do semestre, repetiu-lhes várias vezes que precisam entender o porquê dos conceitos básicos e indicou-lhes como devem estudar. Na quase totalidade das aulas, que eram à tarde, fazia muito calor. Muitas vezes senti sono e cansaço e percebi que os alunos também sentiam. $O$ professor também percebia e às vezes encerrava a aula um pouco antes.

No início do curso, insistia em perguntar se estavam acompanhando. Em setembro, percebi que seu ritmo não era lento, nem agitado. Em meados de outubro, prossegue lançando perguntas aos alunos, naquele espírito de não ser necessário dar respostas elaboradas e nem concluir o raciocínio. No início de novembro percebe-se que já não detalha tanto, responde mas não incentiva, faz as resoluções, mas não passo a passo e já vai para alguns resultados. "O objetivo é só mostrar como faz e por isso não vou detalhar. Depois vocês fazem” ( Prof. A ).

O ritmo do professor B permite continuidade de explicação, anotação pelos alunos, perguntas, respostas dele como também dos colegas que vão, então, participando, num clima de descontração. As explicações são dadas de frente para os alunos, virando-se para a lousa só no momento das anotações das resoluções, o que faz organizadamente. Responde as perguntas com boa vontade, demonstrando interesse e gosto quando perguntam. Percebe-se isso porque interrompe o que estava resolvendo, aproxima-se mais dos alunos, explana o que foi perguntado, não manifesta 
pressa em voltar à lousa, dando chance para intervenções. Os alunos parecem à vontade e o professor também. Sinto-me à vontade igualmente.

Quando acha que algum exemplo é interessante, diz isso e explica o porquê. Os alunos são atentos nas explicações e no que é escrito na lousa. Acompanham sinalizando com a cabeça, como também falam e, em seguida, o professor fala e escreve na lousa. Se ele se engana momentaneamente, os alunos corrigem logo. Percebo que eles fazem comentários explicativos e de relações e não só de perguntas. Penso que isso ocorre porque são alunos de final de curso e o ambiente de sala de aula permite. Se o aluno discorda ou lança outro ponto sobre uma explicação, o professor diz que "é bom porque vai puxando naquilo que vocês mesmos vão percebendo". Sinto que ele se sente recompensado. Ele fala bastante, mas calmamente, sem queimar etapas, parece que com a preocupação de dar uma aula clara, passo a passo. Cita onde os problemas podem ser aplicados. Em uma das aulas, um aluno perguntou sobre a contribuição daquilo que estava sendo ensinando e ele explicou historicamente. Tenho a impressão de que ele gosta muito mais de entender, explicar, descrever, historicizar, do que de calcular, embora as aulas tenham também muito cálculo.

O professor C ministra Física Básica para alunos do primeiro ano. São aulas de teoria e de laboratório. Nas quatro aulas semanais, desenvolvia teoria em duas delas e em seguida os alunos iam para o laboratório realizar as práticas. Não era regra geral porque havia semana em que nas primeiras duas aulas a prova era feita e nas duas seguintes a correção da mesma. Outras vezes, depois da prova os alunos assistiam a algum filme didático. Também houve semana que o professor usou todo o tempo disponível para teoria e exercícios. Ele verbalizou, nas entrevistas, ter um bom controle técnico sobre o conteúdo da disciplina e, realmente, isto pode ser observado.

Com relação à preocupação com o que chamou de "parte didática", observei que ensina falando, perguntando bastante e respondendo as perguntas dos alunos, não só explicando, como também levando o aluno a pensar. Lança mão da História da Ciência para introduzir os conceitos, sem sofisticação. Também concretiza a explicação utilizando objetos e situações presentes ali no contexto de sala de aula. Sua aula é descontraída, ele é entusiasmado, sua fisionomia é risonha e são contagiantes seu entusiasmo e suas expressões faciais e corporais. Parece incansável, embora tenha dito numa entrevista que sai da aula "morto de cansaço". Movimentase pela sala o tempo todo, anda ao redor das mesas dos alunos nos momentos em que estes estão resolvendo exercícios, fala com eles, ouve-os 
com atenção, valoriza suas intervenções e suas tentativas para concluir algo. Seus ex-alunos iam para a porta da sala e ficavam olhando a aula, quando os intervalos ocorriam em momentos diferentes, e comentavam comigo que sentiam saudades de suas aulas.

Muitas vezes me perguntei como os alunos do professor $\mathrm{C}$ não dispersavam, não faltavam e permaneciam até o final, numa aula que ocorria às sextas-feiras e, oficialmente, das 19 às 23 horas (geralmente este último horário era ultrapassado). Suas expressões manifestavam certo cansaço pela semana toda de trabalho e aulas, mas eles continuavam interessados. Professor e alunos ficavam o tempo todo em atividades. Nas aulas teóricas, falava e detalhava muito, mas os alunos interrompiam e se necessário insistiam. $\mathrm{Na}$ introdução de conceitos novos, falava bastante sobre o assunto, explicava tudo que julga importante e depois formalizava. "O formalismo é uma ferramenta". Incentivava respostas descomplicadas e se o aluno respondia com fórmulas, pedia para não dar frases prontas e alertava que eles já têm "a linguagem necessária”.

Foram observadas as aulas das duas disciplinas ministradas por um mesmo professor. Em Astronomia, ele prepara as aulas e até começa com as noções fundamentais, mas vai se entusiasmando, falando e respondendo perguntas dos alunos, sem muita preocupação com o tempo que a resposta leva. Envolve-se com o assunto e, às vezes, acaba se distanciando do ponto de partida ou do que havia programado. Constantemente refere-se à história da Astronomia. Essa ciência é palpitante e os alunos demonstram curiosidade. O professor é simples e acessível nas explicações. Utiliza fatos e fenômenos do cotidiano, facilmente observáveis, menciona curiosidades astronômicas ligadas às comemorações de festas religiosas, enfim, vai recheando com considerações, observações pessoais, leitura de jornais, revistas e livros, percepções de situações do cotidiano e enriquece sua aula com o conteúdo científico e com as informações culturais, importantes para se entender as noções, adquirir o conhecimento e não se ficar no senso comum. O professor é gentil e atencioso ao responder as perguntas dos alunos. Sua dicção é ruim e ele tem dificuldade com aula expositiva, o que, aliás, já havia dito numa das entrevistas.

$\mathrm{Na}$ outra disciplina, Instrumentação para o Ensino de Física, os alunos confeccionam os recursos instrucionais para serem utilizados nos minicursos ministrados em escolas da Rede Pública, como requisito parcial da disciplina Prática de Ensino de Física, onde fazem também a parte teórica. Nas aulas iniciais, professor e alunos decidem os instrumentos a serem confeccionados para a realização dos experimentos 
que serão utilizados. A dinâmica dessa decisão é participativa, com inteira liberdade para sugestões, com o professor assumindo o papel de condutor/orientador. Às vezes, é meio desorganizado, mas como as sugestões são discutidas de igual para igual, isso não se constituiu num problema em termos de resultado final. Entretanto, no processo, os alunos, muitas vezes, sentem-se confusos e sem direção. Isso ocorre porque as sugestões são inicialmente em avalanche e os alunos ficam receosos de que o tempo não seja suficiente para tantas intenções. São discutidos também outros recursos instrucionais como confecção de um vídeo educativo (que realmente foi editado) e apostilas.

É um estilo diferente de curso. Não são aulas no esquema tradicional de transmissão de conteúdo e cumprimento de programa. São contatos semanais de quatro horas, no horário de aula, entre os alunos e com o professor para discussões, decisões, estudo, preparação e confecção. Após as decisões, a turma de alunos se divide em grupos, cada um deles com a responsabilidade de tomar todas as providências com relação ao seu tópico. A infraestrutura necessária é proporcionada pelo CDCC.

Além de estarem programando e confeccionando tudo referente ao minicurso, o professor designou-lhes outra atividade que foi desenvolvida em paralelo. Os alunos reconstituíram e puseram em funcionamento aparelhos e instrumentos do início do século, que estavam em desuso no antigo Instituto de Educação da cidade, hoje uma escola estadual de $2^{\underline{0}}$ grau. Os objetivos de tal atividade foram: conhecer aparelhos antigos, alguns deles ainda utilizados em escolas em que eles poderão vir a dar aulas; conhecer a história da Física a partir deste rico material e ensinar o seu funcionamento aos alunos daquela escola para que estes monitorassem visitantes da Feira de Alta Tecnologia. Ao final do semestre, os alunos ministraram o minicurso, utilizando os experimentos, as apostilas, os exercícios e o vídeo.

A execução de cada um pode enfatizar a visão mecanicista/ memorística, a da produção do conhecimento, o pensamento convergente, o pensamento divergente, a decodificação de fórmulas, a aplicação delas, o questionamento aos alunos e incentivo ao raciocínio, a passividade e absorção, ou seja, a execução é opção do professor. "A prática tende a repetir a prática” (Cunha, 1994, p.121). É preciso aprender o exercício da reflexão sobre a prática.

Nem sempre os significados estão explícitos ou são conscientes para o professor. A intuição e a experiência são imprescindíveis, mas a reflexão e a iluminação da prática docente por meio da teoria não devem jamais ser desconsideradas ou secundadas. 
"Em última análise, tudo se decide no processo de reflexão que o professor leva a cabo sobre a sua própria acção. É uma dimensão decisiva da profissão docente, na medida em que a mudança e a inovação pedagógica estão intimamente dependentes deste pensamento reflexivo" (Nóvoa, 1992a, p. 16).

Também os métodos que os professores utilizam dependem das suas opções pedagógicas e da natureza das disciplinas. Nóvoa (1992a) é decisivo nesta questão, ao afirmar que aquilo que fazemos na sala de aula e o como fazemos, é uma

"mistura de vontades, gostos, experiências, de acasos até, que foram consolidando gestos, rotinas, comportamentos com os quais nos identificamos como professores. Cada um tem o seu modo de organizar as aulas, de se movimentar na sala, de se dirigir aos alunos, de utilizar os meios pedagógicos, um modo que constitui uma espécie de segunda pele profissional" (Nóvoa, 1992a, p.16. Grifo do autor).

Talvez o fato de ser sentido como uma segunda pele profissional, dê a esse modo - o ensino - uma relevância tal que leva os professores, na prática, a terem maior preocupação com ele do que com a sua consequência: a aprendizagem. Dessa maneira, da categoria docência, emergiram os focos concepção de ensino e concepção de aprendizagem.

Nas entrevistas, a pergunta sobre o que eles pensam a respeito da aprendizagem desencadeou comentários que levaram a essa percepção, ou seja, a de que os professores, mesmo pretendendo falar da aprendizagem, referem-se mais ao ensino.

À medida que o semestre letivo vai chegando ao final, observa-se maior preocupação docente com o cumprimento do conteúdo programático do que com a aprendizagem propriamente dita. No caso do professor A, essa alteração de comportamento foi mais nítida. Por outro lado, o professor $\mathrm{C}$ relatou, na entrevista, que preferiu abandonar parte do programa, no ano anterior, pois os alunos não conseguiram acompanhar o desenvolvimento do conteúdo.

Apesar de não lhes ter perguntado sobre ensino, suas respostas levaram-me, nas aulas, a atentar, também, para esse aspecto. Constatei que na maioria delas, grande parte do tempo é dedicado a cálculos e que a formalização matemática, mesmo quando precedida de uma 
explanação sobre os conceitos envolvidos, é uma constante, exceto nas disciplinas Instrumentação e Astronomia. A quantidade de cálculos era maior nas disciplinas dos últimos semestres do curso de Bacharelado e menor na classe dos alunos ingressantes em Licenciatura.

Considero que isso decorre do fato de poder ser a Física entendida como um sistema teórico, no qual se atua transformando proposições de acordo com regras determinadas, operando sobre um conjunto de noções definidas axiomaticamente, isto é, trata-se de uma área do conhecimento assemelhada a de uma teoria matemática. Esse conjunto de axiomas e de operações é usualmente denominado de modelo teórico. A Física pode ser vista, então, como consistindo de uma sucessão de modelos encaixados que descrevem teorias cada vez mais poderosas, englobando progressivamente um maior número de situações e domínios. Os modelos mais antigos podem ser considerados casos particulares dos modelos modernos, mantendo, entretanto, sua validade para um determinado campo de aplicação, permanecendo, portanto, como objeto de estudo e ensino e de utilização no domínio tecnológico (Halbwachs, 1975).

Como os modelos mais complexos envolvem conceitos contidos nos mais simples, mas por outro lado, um instrumental matemático mais sofisticado, o ensino é executado por etapas, pretendendo-se uma sucessão de aquisições de conhecimento e suas respectivas aplicações pelos estudantes.

O modelo ensinado nos primeiros anos dos cursos (Bacharelado e Licenciatura) está baseado na mecânica newtoniana e mais próximo da realidade do mundo físico que pode ser observado cotidianamente. Guarda, portanto, uma relação mais direta com as constatações do que ocorre na natureza, bem como é a base da tecnologia pré-microeletrônica que continua presente no nosso mundo. O Prof. C abordou essas questões, dizendo na entrevista: "Hoje em dia, em Física, ainda estamos ensinando a Lei de Newton, e nunca vamos poder deixar de ensiná-la só porque ela tem mais de 300 anos. Não é a idade da lei que a torna menos importante. Ao mesmo tempo, nós temos que aprender computação, por exemplo, toda esta parte da tecnologia envolvendo a informática de modo geral. Mas não deixaremos de aprender a Lei de Newton. Não tem uma maneira de formar um estudante que ao final de quatro anos saiba todo o desenvolvimento que existe hoje e que ao mesmo tempo tenha a capacidade técnica de usar a Lei de Newton".

O modelo, entretanto, por mais sofisticado que seja, é só uma interpretação parcial da realidade, não se confundindo com ela. Levar, 
para a sala de aula, situações relacionadas com o mundo físico e com os objetos criados pelo homem possibilita troca de experiências entre os fenômenos observados e aquelas relações que resultam de operações sobre o modelo. Essa possibilidade é coerente com a teoria ensinada no início dos cursos, tornando-se inviável com o maior nível de abstração dos modelos da Física Moderna, onde as relações decorrentes só podem ser confrontadas em experimentos sofisticados.

Talvez por isso um dos professores acredite que "é mais importante convencer o aluno da importância dele aprender, do que ficar preocupado se ele realmente aprendeu tudo" (Prof. A).

Como seus alunos são do último ano, supõe-se terem atingido essa abstração maior. Mesmo assim, incomoda esta fala que transfere para o aluno toda a responsabilidade e, pelo contrário, encontra consonância a opinião de que "só pode dizer que sabe, aquele que é capaz de fazer o outro aprender" (Prof. B), ou a concepção de que "se o professor é bem preparado, vai com disposição de fazer os alunos aprenderem e não vai lá dizer aos alunos para aprenderem, as chances são maiores". Ele insiste: "se você vai bem preparado tecnicamente e com espírito de sentir prazer por vê-los aprender, a combinação desses dois fatores tem uma grande chance de resultar numa boa aula" (Prof. C).

Embora várias vezes, nas entrevistas, o professor $\mathrm{C}$ tenha falado sobre o aspecto técnico, suas atitudes em sala de aula denotam um comportamento criativo e de envolvimento. O professor, na sua preocupação com o que chamou aspectos técnicos da disciplina, não percebeu, ainda, que o seu sucesso está ligado muito mais à interação com os alunos, à postura de incentivo aos questionamentos, ao reconhecimento das contribuições dos alunos e à valorização da atitude de tentar aprender. Essas são situações imprevistas, não planejadas, mas que ocorrem na sua prática docente. Por sua imprevisibilidade, as situações não podem ser resolvidas no âmbito exclusivo da racionalidade técnica, mas sim, integrada com o "pensamento prático" do professor. Nas palavras de Pérez Gómez,

"o conhecimento que se mobiliza para enfrentar as situações divergentes da prática é do tipo idiossincrático, construído lentamente pelo profissional no seu trabalho diário e na sua reflexão na e sobre a acção. $O$ conhecimento das ciências básicas tem um indubitável valor instrumental, desde que se integre no pensamento prático do professor" (Pérez Gómez, in: Nóvoa, 1992a, p.111). 
O professor $\mathrm{C}$ não fez referência à atitude reflexiva tendo, entretanto, manifestado que na sua prática docente foi adquirindo "mais segurança" para aproveitar as perguntas e questionamentos dos alunos. Num momento das entrevistas afirmou que se a aula não foi boa, tem a tendência de fazê-la de novo porque não ter ido pelo caminho certo é ruim para o aluno que está vendo pela primeira vez, o que não deixa de ser uma reflexão posterior ao acontecimento, que resulta, evidentemente, em aquisição de novas atitudes.

Para o professor B não existe bom professor no sentido da pessoa que ensina. É aquele que orienta e ajuda o outro a aprender. "Centralizo minha opção na aprendizagem dos alunos. O professor permite que o aluno aprenda se desce ao nível dele e vai crescendo com ele. Não adianta querer que eles subam ao nível do professor porque isto é fazer o processo contrário. Tem que caminhar junto para fazê-lo aprender."

Suas colocações levaram-me a refletir sobre a importância de descobrir os conhecimentos já adquiridos pelos alunos, sua familiaridade com o discurso científico, para, a partir daí, orientá-los no caminho das novas aquisições. Para que isso aconteça, são fundamentais as condições que pude observar em sala de aula: o diálogo que se estabelece, a interação satisfatória, a demonstração de que gosta do que faz, as conversas que ocorrem quando saem da sala junto com o professor, seu jeito simples, acessível e próximo dos alunos.

Considero importante na categoria docência, o estímulo à tentativa de produção intelectual pelos alunos e a apropriação que cada um faz (aprendizagem significativa), muito mais do que a absorção dos conteúdos. Esta se relaciona ao binômio transmissor-receptor, aquela ao incentivo à construção do conhecimento.

Nesse sentido, os comportamentos de perguntar, mas ainda de discordar argumentando, comentar e até de trocar explicações entre os próprios colegas eram mais frequentes nas aulas do professor $\mathrm{B}$, cujos objetivos vão na direção da aprendizagem dos alunos. Na disciplina do professor A, que também é de final de curso, ele prefere lançar as perguntas e quando o aluno questiona, responde de boa vontade, mas não incentiva, não envereda pela hipótese do aluno justificando que precisaria partir de outro início. Nas entrevistas, havia mesmo dito que quando o aluno sugere uma pista, vai adiante se tem conhecimento, explica um pouco e promete voltar ao assunto se sabe pouco, e se não sabe diz que não sabe. "Os alunos costumam fazer questões que nada têm a ver com o tema e o professor não pode comprometer o curso, mas também não pode dizer para o aluno e, então, faz um "meio campo" e prossegue. É comum não terem aprendido o 
que deveriam e por isso estar com dificuldades no que você está fornecendo".

De minha parte, acredito que se o aluno não sabia vai continuar não sabendo, além de, possivelmente, passar a desinteressar-se, pois percebe que a preocupação não é oportunizar participação e dar chance para raciocinar e construir hipóteses. O objetivo não é o processo, mas sim o produto. As colocações do aluno podem não estar diretamente dentro do curso, mas têm muito do interesse dele. No entanto, como os cursos são planejados pelo professor sem a participação dos alunos, a decisão é do professor quanto ao que é importante para alunos adultos e às vésperas da diplomação, principalmente porque $o$ docente se considera um "fornecedor".

Na disciplina de Física Básica, para os alunos ingressantes, eram mais frequentes os comportamentos de perguntas e de insistência até entenderem. Nem sempre, mas algumas vezes lançavam hipóteses, tentando fazer transferência de conhecimento para outras situações (e isso é importante na aprendizagem). $\mathrm{O}$ professor $\mathrm{C}$ incentivava para falarem sem receio, explicitarem o raciocínio e explicarem o porquê do resultado com as próprias palavras. Por essas e outras atitudes, observei que embora o professor se propusesse a "ensinar Física e não como o aluno deverá ensinar Física", na realidade ensina a ensinar.

O professor D tem atuações diferentes nas disciplinas. Em Astronomia, prepara a aula. Em Instrumentação, apenas pensa sobre a aula. O material para Astronomia é feito por ele. São: apostilas, cartazes, gráficos, esquemas, resumos em transparências, além daquilo que existe no Observatório. Em Instrumentação, orienta e os alunos fazem: apostila, experimentos, filme educativo etc.

Em Astronomia, a aula é dirigida e ele expõe (não muito), explica, mostra os gráficos, dirige observações, responde perguntas que geralmente são numerosas, porque os alunos se sentem curiosos, mas não deixa tão solto. É uma atividade mais dirigida, o docente é atencioso e de boa vontade. Em Instrumentação, interage mais com os alunos. Seu eixo condutor em Astronomia é informá-los sobre a referida ciência. Em Instrumentação, é preparar e instrumentalizar tecnicamente o futuro professor.

Se o aluno sugere uma pista, não reluta. Ele mesmo diz que perde o fio condutor da aula. Repassa conhecimentos, mas instrumentaliza também, orientando e coordenando. 
Os professores reconheceram que os resultados da aprendizagem são limitados, porque o aluno tem seu tempo dividido entre outras disciplinas:

"O professor não consegue ensinar tudo o que sabe, nem daria, pois o aluno pensa diferente. Ele vai ter que aprender da maneira dele. Foi assim que eu aprendi" (Prof. A).

"Não tenho ilusão de que uma disciplina vá dar o domínio do conteúdo. O aluno vai ter uma ideia geral e alguma intimidade com o assunto. Só vai saber mesmo, quando tiver tempo para reflexão sobre o assunto e oportunidade para pesquisar, ensinar, utilizar" (Prof. B).

"Não dá para ensinar tudo. O professor deve se preocupar em ensinar aquilo que permita ao aluno, por si próprio, procurar as coisas" (Prof. C).

Observei, também, a preocupação de alguns dos professores com a questão da linguagem como um veículo de compreensão, numa tentativa de superação das dificuldades do discurso científico, com sua terminologia técnica e seu simbolismo matemático. O professor $\mathrm{C}$ insistia para que procurassem explicar sem termos rebuscados, as questões conceituais estudadas, evitando o uso da simbologia matemática. Procurava, assim, garantir a compreensão dos conteúdos na linguagem concreta do aluno, tendo levado essa preocupação ao processo de avaliação.

Assim se expressou: “... fui percebendo ao longo do tempo que as questões colocadas nas avaliações são de ordem puramente técnica: calcule, determine, mostre, prove ... Não tem nenhuma questão do tipo: escreva, fale sobre, o que você pensa sobre ..., como você descreveria, ou explicaria ... Então passei a colocar, nas provas, questões desse tipo (e eles foram avisados) e percebi que as redações são péssimas, não só com erros gramaticais, mas principalmente por não expressar aquilo que estão querendo dizer. Às vezes repetem palavras dos livros sem estarem entendendo nada" (Prof. C).

A avaliação é uma atividade presente nas experiências cotidianas das pessoas, já que analisamos e nos posicionamos com relação aos fatos e situações da nossa vida e dos nossos semelhantes. Essa forma assistemática de avaliar inclui apreciações que fazemos com maior ou com menor dificuldade. No entanto, a avaliação da aprendizagem, definida como uma das dimensões do papel do professor, é o aspecto da prática pedagógica que os docentes, de modo geral, menos gostam de fazer, como é o caso, aliás, dos quatro professores envolvidos. 
Os professores não vislumbram outra saída que não os "métodos convencionais", "as avaliações standard", as "provas tradicionais", mas manifestam insegurança. "Gostaria de despertar neles o interesse em aprender sem preocupação com avaliação, mas não é possível" (Prof. A). "Se tivesse um ensino com outro tipo de avaliação, quer dizer, o aluno mesmo, em conversa com o professor falar "eu sei o suficiente para passar", seria muito melhor, mas isso é utópico" (Prof. B). "Não sei como fazer uma boa avaliação. Ela é ineficiente e cansativa" (Prof. C). "Talvez o meio que escolhemos para avaliá-los não seja tão adequado. É preciso ver o que significa esta prova e porque eles têm dificuldades" (Prof. D).

Os professores afirmaram que suas avaliações estão relacionadas com os processos de ensino, procurando, ainda, utilizá-las continuamente através de provas e listas de exercícios. Na disciplina ministrada pelo professor $\mathrm{C}$, as listas de exercício não são consideradas diretamente na avaliação, mas nas provas, pelo menos um dos exercícios constantes da lista faz parte do conjunto de questões. Este professor também utiliza espaços de tempo nas aulas para que os alunos resolvam exercícios propostos, sob sua orientação. Esses exercícios em aula, não são utilizados para quantificação. Eles representam um dado qualitativo importante no processo de ensino, pois possibilitam que o professor, percorrendo as carteiras dos alunos, aproximando-se deles para ouvir suas dúvidas e orientá-los, obtenha informações de como está sendo desenvolvido o processo de aprendizagem.

O professor B monta a prova com base nos exercícios e conceitos do livro-texto e os alunos sabem disso. Se a turma é pequena (até quinze alunos), faz prova oral "que é importante porque é onde você descobre se os seus alunos sabem os conceitos". Quando o professor citou prova oral, imaginei o sistema tradicional, normalmente designado por entrevista (Abreu \& Masetto, 1990; Libâneo, 1991). Na continuação, descobri, entretanto, que seu sistema de entrevista era original. "É um "pingue-pongue" de perguntas e respostas. Entram dois alunos na sala. Pergunto sobre um conceito e deixo um deles falar. Pergunto ao outro se ficou satisfeito com a resposta e se não ficou, como pode contribuir. Termino mostrando o que o conceito é realmente e cada aluno fica sabendo o que não sabia ou reforça o que sabia. Eles aprendem com essa situação. É também uma oportunidade de aprendizado. Percebo claramente quando o aluno sabe e quando busca numa memória obscura e vai indo porque o professor vai ajudando".

O interessante dessa alternativa de avaliação é a postura do professor que a utiliza não como uma arma - no que, aliás, a avaliação se 
transformou - e sim num diagnóstico e numa oportunidade de aprendizado, não só de conceitos como também de aquisição da capacidade de explicar/argumentando e da desenvoltura para responder.

Os professores interpretam a questão da nota muito radicalmente, usando-a como critério de desempate no caso de atribuição de bolsas, mas nem sempre a nota define o melhor aluno. Os alunos sabem disso e vão fazer as provas sentindo-se mais tensos do que deveriam. A prova deveria permitir que professor e aluno soubessem quais as suas dificuldades.

O professor D fez referência a uma noção de senso comum que é encontrada na prática docente, principalmente de professores das ciências exatas, de que "curso mole não é respeitado". Em nome dessa crença, a avaliação tem sedimentado o caráter de mensuração e punição, constituindo-se num instrumento tosco e mal utilizado. De recurso e meio instrucional converteu-se em finalidade. No entanto, "a prova pode ser um recurso para o professor fazer um diagnóstico da sua atuação. É o momento da auto avaliação" (Prof. B).

"Em relação à avaliação da aprendizagem, as informações obtidas indicam essa área como a menos conhecida e mais "maltratada" no processo de ensino. As dificuldades vão desde sua concepção até a elaboração dos mais simples instrumentos". (Cappelletti, in: D’Antola, 1992, p. 16).

O professor $\mathrm{C}$, nos dias de provas, divide a aula entre o tempo para a prova e um tempo posterior para explicar cada exercício, tirar dúvidas e, perguntando como raciocinaram e resolveram, mostrar onde e porque erraram, com a ajuda de outro professor e dos monitores.

Assim como ele, o Professor D costuma pedir nas provas uma questão do tipo: "como vocês ensinariam um assunto não a mim, mas a um adolescente, seus futuros alunos de $1^{-0}$ ou $2^{\circ}$ grau". Analisa se as informações são corretas, mas também a parte didática. Ambos procuram, então, acenar aos seus alunos que pensem no como ensinar. Incluem, ainda, os tipos usuais de questões.

Abreu \& Masetto (1990, p.91-96), sistematizaram oito pontos sobre a prática da avaliação. Para eles, "o processo de avaliação - está relacionado com o processo de aprendizagem; 
- deve ser pensado, planejado e realizado de forma coerente com os objetivos propostos para a aprendizagem; contínuo;

- para acompanhar o processo de aprendizagem deve ser

- como um processo contínuo, permite um contínuo reiniciar do processo de aprendizagem, até atingir os objetivos finais;

- deverá estar voltado para o desempenho do aluno;

- deverá incidir também sobre o desempenho do professor e a adequação do plano;

- requer capacidade de observação e de registro por parte do professor e, se possível, por parte do aluno também;

- pode ser apenas avaliação ou contar também com a auto avaliação", dependendo de seus participantes.

$\mathrm{Na}$ categoria dimensão pessoal/profissional agrupei os seguintes focos de análise: idealizações, expectativas, limitações, conhecimentos e habilidades, fatores de modificação e reflexões pessoais.

Nas entrevistas procurei saber dos professores quais eram seus sonhos e suas idealizações com relação a ele, professor, e à sua prática docente.

O professor A deseja elaborar um curso bem preparado e idealiza ter mais tempo para o ensino e para a interação com os alunos, mas alega que o tempo consumido pela pesquisa não permite. "O sonho como professor é preparar um curso que seja desejável por todos os estudantes, um curso bem preparado, com aulas demonstrativas como já fiz uma vez. As idealizações: eu gostaria de ser um professor que pudesse gastar mais tempo com os estudantes num processo interativo maior. Não dá, mas eu gostaria".

$\mathrm{O}$ professor $\mathrm{B}$, nesta e em outras respostas manifesta preocupação com o aspecto pessoal, humano da docência, talvez mais do que com o aspecto técnico, embora este também se faça nítido não só pelas verbalizações, como também por fatores que pude ver nas aulas, tais como a preparação de cada aula, a exposição clara, a atenção às dúvidas, o diálogo durante e após as aulas e outros pontos que já foram alvo de análise. Com relação à perspectiva humanizante, tem feito referência a: empatia, "ganhar o sentimento do aluno" como condição para ganhar a razão, a docência como oportunidade de fazer bons amigos, traduzir o que sabe numa linguagem compreensível, entre outras condições que menciona. Sobre suas idealizações, diz que a melhora vai ser muito mais de clarear ideias, de aproximar-se mais dos alunos pelo nível da compreensão humana 
e de diminuir a distância professor-aluno. "Acredito que a gente vai amadurecendo. Vai diminuindo em quantidade e ganhando em qualidade".

$\mathrm{O}$ professor $\mathrm{C}$ manifestou, nas entrevistas, mais conflitos do que idealizações e/ou expectativas. Porém, nas aulas, o que se verifica são mais realizações e conhecimentos/habilidades. São perceptíveis a sua dedicação e empenho, no entanto manifesta-se insatisfeito nas autoavaliações que faz. Não critica ou denuncia, porém preocupa-se com fatos e situações que percebe no ensino de $1^{\underline{0}}$ e $2^{\underline{0}}$ graus que conhece pelo contato com professores da rede, através de cursos e encontros no CDCC, e com o ensino na universidade.

Após uma das aulas disse-me que os alunos da Licenciatura em Ciências Exatas, por terem muitas aulas de laboratório e práticas para todos os tópicos, poderão desenvolver segurança para, no futuro, repetirem tais vivências para os seus alunos. Comentou, ainda, que percebe insegurança na maioria dos professores da rede, no sentido de dependência muito grande ao livro didático. Afirma que gostaria que os alunos da Licenciatura fossem seguros, já que estão tendo um curso teórico-prático e a obrigatoriedade de cursarem, durante três anos inteiros, as disciplinas de Física, Química, Matemática e Biologia, que propiciam, supõe-se, maiores condições para preparar e ministrar aulas teóricas e práticas, não ficar preso ao livro e, inclusive, poder escolher os melhores livros.

O desejo do professor $\mathrm{D}$ é que as escolas de $1^{\underline{0}}$ e $2^{\underline{0}}$ graus possam contar com a possibilidade de realizar experimentos científicos dentro das salas de aula de ciências, por meio da Experimentoteca. Sua preocupação, portanto, é com a extensão via Universidade. Seu sonho é que "a Experimentoteca se torne um projeto de impacto no país, já que ela é uma forma de disseminar a ciência experimental em sala de aula".

Em outros momentos das entrevistas, procurei saber dos professores quais eram suas expectativas com relação ao curso, aos seus alunos e à sua prática docente.

As respostas dos quatro professores levaram à concordância quanto à expectativa de que os alunos aproveitem bem os cursos que estão fazendo e adquiram segurança. Além desses aspectos, outros foram colocados, na linha das características pessoais e profissionais de cada um dos professores e que já puderam ser evidenciadas no decorrer deste trabalho. Por exemplo, o professor A ressalta o cuidado com as opiniões de alunos que não vão bem e criticam o curso, enquanto os bons elogiam. $\mathrm{O}$ professor $\mathrm{B}$ novamente destaca pontos afetivos de 
relacionamento. $\mathrm{O}$ professor $\mathrm{C}$ ressalta o aspecto da aprendizagem que a pessoa faz ao longo do tempo e, ainda, a singularidade que cada ser humano encerra. Mesmo nas características aprendidas há o toque individual. $\mathrm{O}$ professor D não se esqueceu de algo que incomoda a todos que militam pela causa da educação: o descaso quanto à desvalorização salarial dos professores.

“... que os alunos adquiram a bagagem que necessitam e também vejam os erros que o professor comete para que eles não cometam. É, ainda, importante o aluno aprender a falar com segurança mesmo que ele não saiba. Isso é fundamental em qualquer carreira" (Prof. A).

"A minha expectativa é a seguinte: eu gosto de sair da aula com a tranquilidade de que cumpri bem o meu papel. Eu quero ir para a sala e conseguir dar uma aula que interesse aos alunos e que aproveitem alguma coisa. Minha contribuição é ali e os meus alunos que aproveitaram isso, provavelmente não vão se esquecer de mim. E que continuem meus amigos. A classe é um lugar bom para continuar a ter bons amigos. Se você tem alguma chance de convencer o aluno de que ele pode aprender aquilo, de que se ele estudar vai aprender, quer dizer, se ele ouve é porque você achou o caminho do coração dele e não da razão. Isso é certo. A pessoa só ouve a quem ela gosta" (Prof. B).

"No caso da Licenciatura, a minha expectativa é que eles tenham segurança no que estão aprendendo. Se isso acontecer, vão dar boas aulas e serão bons professores. Eles estão tendo condições de aprender bastante. Eles têm as aulas de laboratório. Tendo segurança eles mesmos vão pegar um livro, outro, e vão escolher o melhor livro para ensinar e isto já é um passo para melhorar o ensino. Eles têm que se preocupar em dar boas aulas, preparar bem as aulas. No Bacharelado também espero que se ele for professor, se preocupe em ter uma capacidade grande do ponto de vista técnico. Seja atirado, destemido para fazer os cálculos e tenha uma certa atitude perante as coisas. Que não tenha muito medo. E com uma certa segurança vai indo, voltando e consertando. Na pesquisa você precisa fazer assim. Não pode ficar parado. Não sei se a gente ensina isso para os nossos alunos. Talvez seja uma coisa pessoal que só o aluno possa desenvolver. Talvez pudesse ter cursos para aprender a ser mais criativo, ou que estimulasse mais a criatividade. O laboratório talvez pudesse ser um meio de estimular mais a criatividade" (Prof. C).

Nas aulas, os professores não conversam com os alunos sobre as suas ou as expectativas deles, em termos da profissão ou de futuro. A não socialização dos objetivos, programação, conflitos e finalidades, 
fazem com que a interação seja centrada no conteúdo e na sua execução. Também não compartilham suas limitações ou dificuldades.

Procurei saber das frustrações dos professores, suas ideias que não deram certo e por quais motivos e, quando as respostas permitiram, quais as limitações pessoais, institucionais e profissionais que tiveram influência em sua prática docente.

O professor A encara como dificuldade a falta de tempo para dedicar-se ao ensino, porque "a vida profissional do professor universitário depende da pesquisa e é muito difícil ser um bom professor se não estiver associado a ela". Nas aulas, a forma como os problemas são propostos não é para que os alunos redescubram o assunto, mas para que sejam informados e depois se aprofundem, estudando e fazendo exercícios. Portanto, o privilégio, na aula, não é para atitudes investigativas.

O professor B acredita no tempo, no esforço continuado e diz que não tem angústia alguma porque aceita-se como é. "Sei que sou uma pessoa limitada, mas que eu posso melhorar e a melhora consistente é lenta".

Já o professor $\mathrm{C}$ tem uma série de frustrações relacionadas ao fato de não conseguir entender e resolver situações que acontecem no ensino. Não só na resposta específica sobre as suas dificuldades, mas no decorrer das entrevistas, mencionou suas "muitas frustrações": - quando acha que a aula não foi boa ou acontece algo que não previu, diz que é "mortal"; - acha que o professor, dando aula, aprende muito porque estuda e prepara os assuntos durante vários anos seguidos, olha tudo com profundidade, vê o que tem ao redor daquele tema para conhecê-lo melhor. Com isso acaba aprendendo mais e o aluno, com quem isso devia acontecer, não acontece; - acha que o professor deveria colocar as ideias na lousa e o caminho de como se sai de um lugar e se chega ao outro, na tentativa de não fazer tantas contas, mas não funcionou porque não teve retorno da classe. Não conseguiu que os alunos fizessem os cálculos e precisou voltar ao usual, que é o professor fazendo quase tudo na lousa enquanto o aluno fica olhando. Com isso o professor treina, aprende bem e o aluno copia, pensa que entendeu, mas quando vai fazer, não consegue; - a aula de teoria, exceto para a Licenciatura em Ciências Exatas, na modalidade em que ela está ocorrendo, costuma ser muito desconexa da aula de laboratório; - ter que dar aula e fazer pesquisa ... . "Pesquisa é algo que toma muito tempo e então não dá para conhecer bem todas as práticas possíveis do laboratório de ensino, ver quais se adaptam melhor a cada tópico, prepará-las e utilizálas"; - ressente-se de turmas passivas que não solicitam bastante o professor, inclusive antes e depois das aulas; - no novo currículo o número 
de créditos-aula foi diminuído para que os alunos tivessem mais tempo para o estudo. Entretanto, os professores não sabem como guiá-los e os alunos não sabem como fazer isso; - com relação aos exercícios que passa para que eles façam em casa, verifica que nas provas eles não acertam porque não têm o hábito de estudar continuamente. Além disso, não entende porque um problema dado no cursinho é resolvido, enquanto um exercício ensinado na faculdade eles não fazem.

Nas dificuldades que aponta, o professor $\mathrm{C}$ considera o papel do docente muito importante e "a atitude do aluno, fundamental". Costuma conversar com os alunos para que mudem de uma posição passiva, em que "ficam olhando as coisas", para uma postura mais ativa, "como algumas turmas que perguntam bastante na aula, vão à sala do professor, aproveitam quando o encontram no corredor ou na biblioteca, pedem aulas extras e até explicações de outras disciplinas".

O professor D afirma não "tocar-se mais" com o fato de perceber que "as melhores ideias são as que deram pior. As melhores ideias são com relação a um trabalho mais aberto, mais participativo, na nossa estrutura de faculdade punitiva quanto ao aluno". O professor referiu-se aos cursos para turmas grandes (mais de 60 alunos), pois atualmente o número de alunos das disciplinas sob sua responsabilidade é pequeno e seu trabalho é não-diretivo.

Não querendo simplificar que uma adequada formação pedagógica seja a "tábua de salvação" de todas as mazelas do ensino, é preciso reconhecer que muitas das dificuldades mencionadas, principalmente pelo professor $\mathrm{C}$, decorrem da ausência daquela formação. Além disso, as trocas, discussões e formas de melhor equacionamento das situações, não encontram espaço em todos os níveis de ensino, inclusive na universidade, principalmente em cursos de Ciências Exatas, o que acaba fazendo do professor um ser isolado, nos seus sucessos e insucessos.

Perguntados sobre os tipos de conhecimentos e habilidades que os professores precisam desenvolver em si mesmos e quais competências devem ajudar os alunos a adquirir, o professor A optou por levar o aluno a desenvolver a conscientização de que o que ele está aprendendo é importante, não pode ser adiado e é preciso estar sempre motivado nas aulas. "Para um professor ser bem sucedido ele tem que ter conseguido o objetivo de seu curso que é transmitir um determinado número de informações e uma dose de formação elevada aos estudantes".

Esta resposta, momentaneamente entendida como objetivando informar e formar ou seja, instruir/educar o aluno foi, no 
entanto, explicada como sendo "o aluno adquirir os conceitos e tê-los bem estabelecidos na cabeça. Uma formação boa é ele saber aplicar aquilo que aprendeu em problemas que lhe são submetidos. $\mathrm{O}$ estudante pode saber que a informação está disponível, mas tem que receber formação adequada para pegar o que aprendeu e aplicar para o problema. Em termos de informação ele tem que saber muitas coisas de todos os cursos". Essa é a interpretação do professor sobre formação. Assim entendida, ela sofre redução à condição de adestramento. Dessa forma, prevalece a quantidade e o treinamento.

O professor B esclarece que executa "as coisas dentro das próprias limitações". Tem sua "maneira de pensar, mas no modo de agir, cada um dá o que tem. Muitas vezes, a aula é "arroz com feijão", porque não tem outro jeito. $\mathrm{O}$ próprio assunto não ajuda muito. Tem dia em que a aula é melhor, tem dia que é pior. Há dias em que os alunos participam mais, vira um debate e os alunos gostam. Outras vezes a aula é meio maçante, pesada. Tem assunto que é empolgante e se o professor o domina bem, a aula é boa. O único ponto em que já tive algum aborrecimento foi com avaliação. Um ponto que é fundamental, para construção da melhoria da qualidade de um docente é o intercâmbio com os alunos, é uma conversa aberta com eles".

Este professor assume a responsabilidade e o compromisso pela prática que realiza. Não mascara onipotências que sabe não possuir e nem impotências que não sente. Coloca-se junto do aluno porque sabe que o processo é de ambos.

Para o professor $\mathrm{C}$, as competências que se deve ajudar os alunos a desenvolver resumem-se numa só: "pensar. Esta é a mais difícil de todas porque não existe uma receita fácil de seguir. $\mathrm{O}$ professor acha que com o modelo que há, deve estar fazendo isso. Basicamente, chegar na sala de aula e seguindo um certo livro, explicar para o aluno o que está escrito, achando que depois de alguns anos ensinando aquilo que aprendeu, dá uma contribuição um pouco mais pessoal".

De fato, para que se aprenda algo é necessário que se reflita sobre o assunto, combinando e relacionando conceitos já apreendidos com os do novo conteúdo. Ao pensar, o Professor $\mathrm{C}$ acrescentou o fazer, que é por ele colocado como condição necessária para que os relacionamentos necessários ao aprendizado possam ocorrer. "Entretanto, enquanto ele não fizer as coisas por si mesmo, não vai pensar. Temos que descobrir uma maneira para que os alunos façam, porque quem pensa mais, na maneira como nós damos aula, é o próprio professor. Ao aluno parece que cabe uma 
porcentagem menor deste raciocínio todo. Quando só se enxerga a pessoa fazer, no máximo consegue-se reproduzir e não aprender a sair-se bem numa situação nova".

Quanto aos conhecimentos e habilidades necessários para o exercício da docência, o professor $\mathrm{C}$ colocou dois pontos que considera fundamentais: "o primeiro é saber muito bem o assunto e ter boa formação técnica. O segundo é gostar de dar aula. Nem um e nem o outro, por si, vai funcionar. Acho que toda esta discussão que se faz, sobre ensino, até em nível nacional, é muito válida e tem melhorado as coisas com o tempo, mas não se pode prescindir desses dois pontos fundamentais".

Sem dúvida, não só na profissão de professor, o profissional necessita do conhecimento e de sentir-se bem naquilo que faz. "Uma vez que sabe bem, vem a preocupação quanto ao como transmitir. Do lado do aluno, ele teria que estar interessado, ser curioso, querer saber como é, interromper para perguntar ... . Assim, ele muda o curso das coisas e, na maioria das vezes, isso é muito bom. O professor sempre tem que permitir que ocorra. Aliás, é o que deveria acontecer o tempo inteiro. O que é normal na pós-graduação, em que o orientando conversa com o orientador devia acontecer na graduação: o aluno conversando com todos os seus professores, pelo menos antes de começar a aula e ao seu final" (Prof. C).

A interação tem sido um aspecto destacado pelos professores desse estudo, assim como pelos estudiosos da prática docente, alguns deles apresentados neste trabalho. Ela é mencionada pelo professor B como o ponto fundamental da melhoria da qualidade de um docente e é retomada pelo professor $\mathrm{C}$, que a considera satisfatória até por permitir "mudar o curso das coisas". Vista como normal na pós-graduação, onde as decisões são conjuntas, é, no entanto, mais distante e reservada na graduação. Os mesmos docentes que estabelecem, na pós-graduação, relação de parceria adulto-adulto, ressentem-se de uma participação mais ativa dos alunos da graduação, que por sua vez, reclamam da falta de "didática" nas disciplinas que cursam.

O professor D discorda e afirma que o preparo pedagógico (treinamento, segundo ele) é menos necessário ao professor de alunos adultos. "O maior treinamento pedagógico deve ser dado aos que trabalham na pré-escola. À medida que o aluno se torna adulto, os professores precisam ser menos preparados. $\mathrm{O}$ adulto se quer aprender alguma coisa, lê um livro". Por acreditar que os livros ensinam muito, porém não ensinam tudo, considero fundamental a presença do professor - ser social, político, espiritual: humano enfim - tanto na vida das crianças da pré-escola como na 
dos alunos adultos. Com relação às primeiras, o professor tem que ser preparado em psicologia da infância e esse ponto é aceito inquestionavelmente, enquanto que a importância quanto à preparação em psicologia do adulto, pelos educadores, não tem sido encarada com a atenção que merece. Fica-se no senso comum de que bem ou mal o adulto sobrevive emocionalmente. É necessário que haja interesse e dedicação na pesquisa e no estudo sistemático da psicologia do adulto, voltada à educação, inclusive para vencer o tabu de não-prioridade. Um dos docentes desse estudo afirmou que aprendeu, por conta própria, psicologia do adulto para estar melhor preparado para o enfrentamento das situações com alunos do $3^{0}$ grau, já que no seu curso de Licenciatura foi tratada a psicologia infantil e da adolescência.

"Nas universidades do exterior, em relação às nossas, os alunos são muito menos ajudados. Lá não se supõe que o professor deva "paparicálos"'. Como já ressaltei em páginas anteriores, a relação que se deve estabelecer entre as pessoas, principalmente no ato educativo, é aquela que caminha, a passos seguros, da dependência e submissão para a autonomia. No entanto, para essa conquista, o papel orientador do professor é esperado, sendo igualmente necessário, o cuidado para que o receio quanto a "paparicar" não acabe levando à omissão. O equilíbrio sempre deve dar o tom.

Ao afirmar que a habilidade necessária para o professor do ensino superior "é a mesma que no segundo grau: perceber o que está acontecendo na cabeça do aluno, o que o aluno pensa; não pode ser um diálogo de surdos, e que também deve dominar o conteúdo, senão nem deveria estar lá", o professor D apresentou uma contradição. Ficou claro, então, que o aluno de $3^{-}$grau também precisa de um professor preparado pedagogicamente.

"Mas é claro que sempre existem os grandes didatas. Às vezes, os melhores pesquisadores são os que mais se preocupam. Com isso, eu não quero fazer a apologia da estupidez. É importante que domine o conteúdo e é bom que se preocupe, mas se não o fizer, não é por isso que não vai participar da universidade. Às vezes, uma pessoa que dá uma boa contribuição não tem a facilidade didática que outros têm”. O professor superior, não necessariamente, é um profissional do ensino. Ele também ensina, mas o professor de primeiro e segundo graus é um profissional do ensino. Ele só ensina. Ele não produz outros conhecimentos" ( Prof. D ).

Esse ponto da profissionalidade docente, levantado pelo professor, não encontra consenso na literatura. Discordo da sua colocação 
quanto a não produção de conhecimentos pelo professor de $1^{\underline{o}}$ e $2^{\underline{o}}$ graus. Se não os produziu, este é, na realidade, o profissional que mais conhecimentos construiu sobre a educação em todos os aspectos que a compõe. Entendo que a referência do professor foi quanto à produção tecnológica que, aliás, não é mesmo prerrogativa do professor de $1^{\underline{o}}$ e $2^{\underline{o}}$ graus, no entanto, nem só de produção tecnológica vive o homem.

Nas aulas, os conhecimentos e as habilidades dos professores se fizeram notar. Cada qual tem suas características próprias que os distinguem nos aspectos pessoais e profissionais, havendo também, comportamentos que são comuns, como já foi descrito em páginas anteriores. É o caso, por exemplo, da programação da disciplina, preparação das aulas, apresentação de exemplos ilustrativos, utilização de fórmulas, contas e cálculos, aulas expositivas, seriedade na docência, aulas que não são adiadas e nem descumpridas em termos de início e término, empenho e interação ( esta centrada mais no conteúdo ), dificuldade com a avaliação, entre outros pontos concordantes. Os discordantes referem-se, por exemplo, à centralização dos interesses na pesquisa e à não estimulação das perguntas (Prof. A), à proximidade afetiva maior e o colocar-se no lugar do aluno (Prof. B), ao maior entusiasmo, à diversificação de recursos, à utilização de exercícios para o aluno resolver em classe, enquanto o professor observa um a um a fim de diagnosticar suas dificuldades (Prof. C), à centralização na extensão e à não-diretividade nas disciplinas que ministra (principalmente em uma delas), entre outros pontos.

As atitudes dos professores estão, na maioria das vezes, relacionadas com suas opiniões. Manifestam coerência, mesmo porque não foram expostos a teorizações pedagógicas superficialistas. Considero já ter descrito suficientemente suas ações, sendo desnecessário repeti-las.

Os quatro professores reconheceram a influência das opiniões dos alunos, dentre os fatores de modificações de suas práticas docentes. Perguntado sobre quais fatores já motivaram mudanças na sua prática, o professor A respondeu: "Eu sinto que certas coisas não andaram direito e modifico. É o próprio feeling. Certas vezes sinto através dos estudantes. $\mathrm{O}$ aluno sempre avalia, mas é difícil essa informação chegar até o professor. Quando chega, eu procuro modificar. Faço uma análise e se realmente tem procedência, procuro melhorar".

$\mathrm{O}$ professor $\mathrm{B}$ considera fundamental estar suscetível às modificações, centrando-as no objetivo de melhorar a aprendizagem. "Se minha tarefa é ajudar os alunos a aprender, tenho que fazer o possível para cumprir isso. A experiência de ensinar é dinâmica e muitas vezes os alunos 
devem participar". Afirmou, ainda, que mesmo não tendo a convicção da utilidade de uma sugestão de modificação proposta pelos alunos, procura implementá-la, pois mesmo que o resultado não seja o esperado, a experiência da alteração tem sempre um resultado positivo para as duas partes: "o aprendizado da tentativa, o aprendizado de que se deve ousar e não ter medo, cercando-se das condições de que não haja comprometimento do curso".

O professor $\mathrm{C}$ sente falta de um mecanismo institucional de avaliação da prática docente e pede para os alunos "falarem sobre o que não está bem". As dificuldades percebidas nos alunos já o levou, em ano anterior, a alterar o ritmo com que vinha desenvolvendo o conteúdo, sacrificando o cumprimento do programa em benefício da compreensão dos estudantes. Relatou outras modificações como resultado da experiência que foi adquirindo: "Hoje eu me sinto muito mais à vontade para aproveitar o que o aluno fala em sala de aula".

$\mathrm{O}$ professor $\mathrm{D}$ relatou que os fatores que o levaram às modificações na sua prática foram autocrítica e percepção de não estar conseguindo chegar onde queria, além "da percepção através dos alunos, mesmo que eles não falem explicitamente. No começo da docência eu era muito mais idealista e muito mais fracassado. Acabava fazendo um monte de coisas que não davam certo. Agora tenho mais vivência e já não erro tanto".

Considero difícil falar de modificações que possam ter ocorrido na atuação dos professores, no espaço de tempo em que estive em contato com suas aulas. A dificuldade tem duas ordens de fatores. A primeira refere-se ao fato de que para eu dizer que tal ou qual professor mudou, seria preciso ter um referencial, por exemplo, tê-lo observado durante um segmento de tempo maior do que um semestre ou, se possível, através de um acompanhamento curto que se repetisse por alguns anos. A segunda decorre da certeza de que as micro-decisões inesperadas que os professores tomam, têm um tom pessoal muitas vezes não planejado e que no momento em que ocorrem só são sensíveis e perceptíveis para eles mesmos. Aquele que observa não está dentro do mundo das ideias, impressões, constatações momentâneas e conclusões repentinas do professor. Este é um mundo pessoal, individual, único e intransferível.

Apesar disso, é preciso considerar um fato que me foi significativo, como também o foi para o professor e para os alunos. Em uma das aulas, no último dia de setembro, o professor $\mathrm{C}$ passou um exercício para resolverem na sala e, como de costume, ficou passando por eles à disposição, caso quisessem mostrar ou perguntar e, ao mesmo tempo, ver as 
direções de suas tentativas e suas dificuldades. Alguns alunos olhavam seus apontamentos e tentavam. Outros procuravam folheando o caderno, outros trocavam ideias, mas na realidade, não concretizavam. Ele, então me disse: "hoje, na entrevista, você perguntou-me que papel tem a intuição e se eu mudava o curso das coisas ao perceber que algo não ia bem. Vou fazer isso agora. Se já havia feito antes, foi inconsciente". Então, na frente da sala, disse aos alunos que deveriam ter feito o problema em dois minutos e que nenhum aluno havia passado do primeiro ponto de armar uma equação. Isso significava que não sabiam. Fez algumas perguntas: deveria dar a prova mesmo constatando que eles não sabiam? Deveria dar a prova e depois esclarecer e continuar o programa? Deveria continuar ensinando o assunto e mesmo que não houvesse tempo para cumprir a programação, o que fosse ensinado seria bem aprendido? Senti que ele se chateou, os alunos também e eu senti muito: por ele que se empenha e pelos alunos que gostariam de saber, mas não sabem. A situação ficou constrangedora. Os alunos ponderaram e decidiram que a prova seria na aula seguinte, portanto sem mudança de data. No intervalo, ele me disse que ao ver os alunos folheando o caderno ficou preocupado e ao vê-los sem "sair do lugar" ficou assustado. Lembrou-se da minha pergunta e julgou que devia tomar uma decisão: a de compartilhar com eles e de alterar data, programação ou o que fosse necessário para preservar-lhes o direito de aprender. Foi uma reflexão na ação. Os alunos se aproximaram e na conversa percebi respeito mútuo, nada de acusação, nem constrangimento ou mau humor. Pensavam juntos, tentando equacionar o problema, não havia cobrança, estavam juntos nessa empreitada. A conversa fluiu bem. Ele disse que provavelmente não estava sendo eficiente e os alunos foram unânimes em dizer que suas aulas são boas. Fiquei pensando na resposta que os professores haviam dado na primeira entrevista sobre perceberem na fisionomia dos alunos se estavam entendendo ou não e tomarem isso por base. Também refleti sobre o aspecto dos professores não terem a tomada de consciência da construção de sua prática.

Os alunos fizeram a prova sem mudanças e se saíram melhor do que todos esperavam. Porém, o episódio teve continuidade no ano seguinte quando fui professora daquela mesma turma de licenciandos. Passados onze meses, tive a oportunidade de ouvi-los referirem-se ao fato, quando estávamos desenvolvendo os temas Interação, Motivação e Avaliação. Os alunos relatavam acontecimentos, em suas trajetórias escolares, que reputavam como significativos em termos desses três assuntos. Uma aluna, então, citou o que havia acontecido naquela aula, dizendo que foi, para ela, um momento importante de integração. Foi um intercâmbio entre adultos, segundo ela. Outro aluno emendou, lembrando que todos se haviam saído bem porque tiveram motivação para estudar e 
vontade de corresponder. Outros disseram que foi a primeira vez que um professor teve a atitude de compartilhar com eles o que estava acontecendo e de fazê-los partes integrantes do processo. Vários deles foram intercalando com comentários. Quiseram saber o que o professor me havia dito. Contei, então, o que acontecera.

Reforcei, nesse dia, minha convicção de que as pesquisas de sala de aula precisam ser enriquecidas com as presenças de alunos. Além disso, este tipo de reflexão conjunta, feita na aula de Psicologia da Educação, só é possível em disciplinas pedagógicas em que a sala de aula é foco de análise, o que colabora para reforçar que a Licenciatura, tida como um curso menor é, na verdade, um curso maior, tanto para futuros professores do $2^{-}$como do $3^{-}$grau. Relacionei, ainda, com um dado de entrevista em que esse mesmo professor, ao falar de suas realizações e aprendizagens no exercício da docência afirmou que "se a classe está junto com o professor e tem confiança nele, não há problemas".

Indaguei dos professores se gostariam de dizer algo que não lhes havia perguntado e suas respostas levaram-me a criar o foco reflexões pessoais, dentro da categoria dimensão pessoal/profissional. No processo de análise das entrevistas constatei que partes dos protocolos poderiam, também, ser destacadas aqui. Pude confirmar, então, algumas ênfases que acredito traduzirem suas convicções.

Assim, o professor A enfatizou as questões curriculares e aspectos de organização dos cursos, insistindo num ciclo básico comum para carreiras diversas, da área das ciências exatas e tecnológicas, aumentando o número de disciplinas relacionadas à Física. Sua argumentação vincula-se ao nível atual dos cursos tecnológicos que estariam formando "técnicos" distantes da fronteira atual do conhecimento. Seu ponto de vista é polêmico, principalmente por ampliar o conceito do que usualmente é entendido por básico, com acréscimo de mais disciplinas. Considero, entretanto que não se pode perder de vista as dificuldades no aprendizado de qualquer campo do conhecimento. A solução para uma possível deficiência no conjunto de conhecimentos e habilidades adquiridos num determinado curso não se esgota na sua reformulação, devendo considerar a possibilidade da formação continuada.

"O governo coloca milhões de dólares para transferir tecnologia para a produção, para a Engenharia, para a Química. E esse pessoal teve a Física praticamente eliminada de seu curso de formação. Então, não dão valor para a Física, nem para o físico. As disciplinas de Física Básica deveriam ser ministradas conjuntamente nos cursos de Engenharia e Física, 
para formar os próximos industriais, gerentes, diretores, que valorizem e apliquem, para que não se gere conhecimento que fica apenas nas revistas. No exterior, por exemplo, o engenheiro elétrico estuda Física Avançada. Aqui nós estamos formando técnicos, enquanto em outros lugares o engenheiro sabe mais que o físico, porque além de saber a parte prática, tem conceitos teóricos muito bem fundamentados. Acho importante o curso básico. Não pode ter um curso básico para engenheiro diferente do curso básico para físico ou químico" (Prof. A).

O professor A foi um dos proponentes de uma reformulação do Bacharelado em Física, com alteração no número de horas dos alunos em aulas obrigatórias, daí o comentário que se segue: "no ensino, o currículo não deve pertencer ao professor nem ao aluno, mas à instituição. Foi feita uma forma de currículo, aqui no Instituto, em que o aluno teria meio período para fazer cursos optativos e estudos dirigidos. Então, seria diminuído o número de aulas às custas de aumentar a interação professor-aluno fora da sala. Não funcionou porque nós não soubemos manter aquilo que foi proposto. O horário deveria ser fixo e o aluno moldarse, mas nós não conseguimos estabelecer um curso e um horário que pertencesse à instituição".

São salutares as tentativas que objetivam maior aprendizagem. Entendo, entretanto, que alterações na grade curricular das disciplinas, por si só não conduzem a resultados satisfatórios se não estiverem acompanhadas, entre outras, por modificações comportamentais de alunos e professores. Colocar a culpa pelo fracasso numa parcela dos envolvidos é reduzir o processo de ensino às suas questões técnicas.

Apesar de não ter vinculação direta com o curso de Licenciatura, o professor A externou a sua opinião: "na Licenciatura a pessoa deve ter informação, mas é preciso ter a formação básica para ensinar. Não precisa de altos conhecimentos porque ninguém quer saber em detalhes como, por exemplo, se faz uma pesquisa em Engenharia Genética, mas o estudante de segundo grau quer saber certamente como é, para que é e para onde vai. São informações".

O professor B demonstrou suas preocupações com os objetivos do Bacharelado, destacando pontos que considera prejudiciais na estrutura curricular e, principalmente, no sistema de avaliação por provas e notas estendido às disciplinas do último ano.

"O curso de Bacharelado deveria ser de cinco anos. No 5 ano, os alunos fariam algumas das disciplinas que estão, atualmente, 
concentradas no $4^{-}$ano (que é um ano muito pesado) e fariam uma monografia de Iniciação Científica. Daí iria para a pós-graduação. O nosso modelo é o americano, que é elitista e brutal porque seu objetivo (de 19201930 até 1960-1970) foi o de injetar muito dinheiro no mercado de trabalho para o físico e daí ter uma imensa massa fazendo Física e poder, então, selecionar as melhores cabeças. Essa é a concepção. Os outros vão ser corretores de seguros, balconistas... . Não é mau ter corretor culto, que acompanha o desenvolvimento da ciência, mas a filosofia de fazer isso é má. No Brasil a massa interessada em Física é escassa e os critérios (pesados) de formação, são os mesmos da americana. A formação francesa era melhor". (...) "Os alunos estão numa transição do conhecimento da Física que veio vindo e chegou a um ponto em que agora estão tendo os conhecimentos de fronteira, de limite da física quântica, que é completamente estranha, nova, foge de todos os parâmetros e raciocínios que eles tiveram até agora. Isso de ser nova, fronteiriça, desconhecida para eles, conjugado com o fato dos professores considerarem que eles têm o raciocínio formal completamente instalado faz com que exijam mais do que os alunos podem compreender. É um ponto crítico de defasagem, de turbulência e de desestabilização. Se este momento fosse bem aproveitado para fazê-los construir o novo conhecimento, orientando-os cientificamente e não cobrando para reprovar ou aprovar, o resultado seria altamente satisfatório. O caráter avaliativo, o caráter da necessidade do produto está a comprometer o processo" (Prof. B).

O professor B também teceu comentários sobre sua realização pessoal e profissional: "no ensino, eu tenho um crescimento pessoal porque reorganizo minhas ideias e passo a ver com mais clareza. Para poder ensinar é preciso ser capaz de ter entendido claramente e, mais do que isso, traduzir numa linguagem que outras pessoas que ainda não tenham o entendimento claro, entendam. O crescimento profissional nem tanto, porque não há uma valorização do trabalho do professor, quer dizer, o fato de eu dar uma boa aula não aumenta um centavo no meu salário ou na consideração mais ampla. Só que localmente há uma consideração”.

"Eu me realizo profissionalmente quando faço um trabalho que gosto e se esse trabalho tem uma transferência de seus efeitos para outras pessoas, então estou exercendo minha cidadania e sentindo-me útil e inserido no contexto da minha vida, da minha profissão, do ambiente em que vivo, enfim do meu contexto social. O professor não é apenas um instrutor. É uma pessoa observada pelos alunos. Eu não perco a oportunidade de, na sala de aula, falar de outras coisas quando tenho chance. Se algum aluno conversa sobre alguma coisa diferente da aula, dou minha opinião e nisso estou ensinando sobre outros aspectos da vida. Não 
me limito a ser um professor só da disciplina. E essas situações ocorrem, mesmo num curso de Física" (Prof. B).

Com relação ao papel da universidade, o professor $\mathrm{B}$ externou sua opinião de que ela deve "preponderantemente, desenvolver conhecimento, armazená-lo e transmiti-lo. Modernamente a sociedade de consumo tem cobrado dela uma participação no desenvolvimento da tecnologia. A universidade pode também fazer isso, mas sem comprometer sua função primeira que é o desenvolvimento do conhecimento e a formação do cidadão, com uma estrutura intelectual capaz de servir à sociedade e de viver decentemente. A população não tem uma formação mínima, básica, para poder aproveitar o desenvolvimento científico. É pena que a universidade não invista mais na formação de professores para poder transferir isso mais facilmente para a população. A culpa não é bem da universidade, eu acho. A culpa é muito mais do mercado de trabalho para o professor de curso secundário, que paga muito pouco".

O Professor $\mathrm{C}$ fez as observações que se seguem (e que foram semelhantes nos professores A e D), confirmando minha opinião de que não ocorre o processo de tomada de consciência, no professor, de modo geral. "As perguntas que você me fez, nunca ninguém fez. Eu nunca parei para pensar e formalizar o meu pensamento a respeito dessas coisas. Todo mundo tem uma noção básica dos assuntos e esta é a que eu tenho. Eu não sei quão precisas foram as respostas, quão valiosas elas possam ser”.

Sua manifestação quanto à realização pessoal e profissional evidenciou a dedicação à profissão que escolheu: "o crescimento das pessoas depende de uma série de coisas e não só do crescimento profissional porque muitas coisas acontecem fora da sala de aula e do departamento, mas eu, para o meu crescimento, dependo muito de que as coisas aqui dentro funcionem bem. Se não funcionam bem, parece que minha vida não está dando certo. Não é desconexo o que acontece aqui dentro e o que acontece lá fora, para mim. A parte profissional influi muito na minha satisfação pessoal".

O Professor D preocupa-se com o professor de $2^{\underline{o}}$ grau. Afirma que ele "precisa de melhores condições de trabalho para poder melhorar sua aula". Discorda dos que dizem que o maior culpado pelo mau ensino é o professor. "As condições em que ele trabalha são lastimáveis. Ele só tem giz e quadro-negro. Se quiser dar uma aula experimental ou fazer uma excursão ecológica, é a maior dificuldade. No caso do $3^{\circ}$ grau, há infraestrutura e se for formada uma equipe que discute, como está acontecendo na nossa Licenciatura, o pior obstáculo já está vencido. $\mathrm{Na}$ 
universidade não se estimula a discussão e a circulação de informações sobre o ensino. Prestigia-se tudo, menos o ensino".

"Para melhorar a formação do professor é preciso estar produzindo alguma coisa que interesse à sala de aula futura. Já repassar o conhecimento com esta preocupação. A cabeça do professor é maior que a sala de aula. Claro que não se vai deixar de dar um tópico por achar que jamais o aluno precisará dele. Se fosse assim seria um treinamento, não uma formação. A formação tem que ser dirigida no sentido de que aquilo pelo menos seja útil. Isso tem a ver com a aula, mas tem muito mais a ver com a estrutura do curso. O curso é que deve estar aberto para os novos meios que estão surgindo. O professor tem o privilégio de ter um interlocutor que é o aluno. Isso faz com que ele necessite adaptar-se ao outro, perceber as novidades que surgem, as mentalidades mudando..." (Prof. D).

No binômio ensino/pesquisa, foco integração/separação, as considerações dos professores sobre essas relações devem ser enfocadas no ambiente restrito a que se referem. Não é minha pretensão aprofundar as questões de integração/separação entre ensino e pesquisa além dos limites definidos: trata-se de estudar a situação particular de professorespesquisadores físicos atuando no ensino de disciplinas em cursos de Licenciatura e Bacharelado em Física.

Como anteriormente mencionado, o presente trabalho foi desenvolvido numa instituição que se destaca por suas atividades de pesquisa. No caso desse estudo, três dos professores são docentespesquisadores e um deles se declara envolvido mais com as atividades de extensão, o que o levou a apenas externar que "sempre que possível devemos aproveitar os resultados da pesquisa nos cursos avançados". Os campos de pesquisa estão distantes de atividades desses professores enquanto docentes de graduação, aproximando-se mais e até integrando-se na docência e orientação da pós-graduação. Segundo Paoli (1988, p.33)

"estaria ocorrendo uma separação organizacional entre produção e consumo de conhecimento no interior da universidade, mediante a caracterização da graduação como uma escola de consumo de conhecimento e a pós-graduação como a escola de produção de conhecimento".

Acredito que pelo menos três fatores importantes envolvem a questão ensino-pesquisa. Denominei-os institucional, motivacional e social. O primeiro é determinado pela exigência exagerada de produção 
científica em detrimento do ensino. No motivacional, o fato de publicar artigos torna as pessoas conhecidas e aceitas pelos seus pares, ao mesmo tempo em que lhes desenvolve o processo de autoestima. É o sentir-se capaz de produzir suas próprias ideias, conversar sobre elas, defendê-las e reformulá-las, ampliando-as. E há o social, ou seja, o reconhecimento mais amplo pela academia.

Esses três aspectos levam a uma valorização das atividades de pesquisa sobre as de ensino, conduzindo a uma situação que pode ser entendida como prejudicial ao desempenho docente. Dois dos professores alertaram para o tempo que a pesquisa toma das atividades de ensino. "A maior dificuldade que eu tenho é a falta de tempo para preparar as aulas adequadamente, para escrever uma apostila, assim por diante, porque a vida profissional depende da pesquisa que você faz" (Prof. A). Para o outro professor, "a pesquisa faz com que você não se dedique ao ensino tanto quanto deveria. Então também pode prejudicar" (Prof. C).

Por outro lado, os quatro professores destacaram as contribuições para a prática docente que decorrem de suas atividades como pesquisadores: o acréscimo de exemplos ilustrativos e enriquecedores dos conteúdos; a possibilidade de, estando num patamar superior de conhecimentos, poderem apresentar os conteúdos numa linguagem acessível aos alunos; o aspecto de motivação, principalmente no caso dos alunos do Bacharelado. Um deles enfatizou que:

"a pesquisa ajuda porque ao aprender mais sobre Física, a pessoa tem mais condições de pegar um livro e entender. Melhora a formação básica e, então, a sua aula pode melhorar. Ajuda, mesmo que não se dê aula exatamente sobre aquilo que se pesquisa, já que às vezes essas coisas são um pouco distantes" (Prof. C).

Outro destacou que "a formação contínua trabalhando em pesquisa ajuda muito no ensino nos seguintes aspectos: o professor passa a ter exemplos mais diversificados para mostrar ou relatar, e por ver de mais alto, enxerga os detalhes que precisam ser clarificados" (Prof. B).

Um deles foi enfático ao afirmar: "eu não acredito que uma pessoa que não faça pesquisa consiga transmitir motivação e ilustrar sua aula com resultados recentes de pesquisas, mostrando a importância daquilo que os alunos aprendem". Para ele, "alunos que fazem pesquisa são mais motivados para aprender. Sabem o objetivo do aprendizado. Os que não fazem, têm, em geral, maior dificuldade em associar o que se aprende com a aplicação" (Prof. A). 
Um dos professores destacou uma questão não abordada pelos demais e nem encontrada na literatura consultada. Na sua visão, é o ensino que colabora com as atividades de pesquisa, pois o docente, ao preparar seu curso, deve procurar esmiuçar os conteúdos por vários ângulos, tentando antecipar as possíveis dúvidas dos alunos, para esclarecêlas. Essa atitude lhe permite ter uma visão com maior abrangência, com possibilidades de utilização de seus resultados em suas atividades como pesquisador. Foram essas suas palavras: "a melhor maneira de aprender as coisas é dando um curso. Dando aula, ensino e aprendo. O ensino nesse caso auxilia na pesquisa" (Prof. C).

Nas aulas pude observar a inexistência de ensino com pesquisa. Esta se encontra presente apenas de modo indireto, na figura do professor que é também pesquisador, e tangencial, como por exemplo na parte laboratorial dos cursos, onde experiências consagradas são repetidas pelos alunos.

É evidente a dificuldade do professor de Física ${ }^{73}$ em levar para a sala de aula, principalmente nas disciplinas iniciais dos cursos, as questões que são objeto de sua pesquisa, já que essas pressupõem um conjunto de conhecimentos que o aluno só vai adquirir com estudos posteriores. Daí decorre, em muitas disciplinas, a impossibilidade de se ter um ensino associado à pesquisa do docente.

Pude, também, concluir das entrevistas e das observações das aulas que, pelo menos num caso, o que se faz é um ensino para a pesquisa e não um ensino com pesquisa. "Você está treinando pessoas para a pesquisa e então tem que vender a elas o entusiasmo de pesquisador. Se você forma um estudante ruim a pesquisa vai mal. Se não se produzir alunos que continuem, que na verdade produzam um saldo positivo de know-how, os papers que produzimos não adiantam nada. Nesse sentido é preciso tratar o curso com profissionalismo. O que se deve deixar são pessoas, pensamentos, maneiras, condutas [de pesquisadores]. E isso é a única coisa que fica. Os artigos que você escreve numa revista, depois de vinte anos ninguém mais lê ou lembra. Se eu deixei alguns estudantes que viraram pessoas-chave, se deixei alguns pensamentos que propagaram, isso sim faz diferença".

No caso desse professor, é tão marcante sua ênfase na pesquisa, que suas afirmações denotam uma atitude preconceituosa pelo ensino: "quando você tem uma turma de físicos é um sonho achar que a

${ }^{73}$ Valendo essa mesma observação para outras áreas do conhecimento. 
turma toda será de pesquisadores. Alguns vão ser bem sucedidos como pesquisadores e outros não. Muitos vão se dedicar a dar cursos o resto da vida. É importante que eles estejam preparados para tomar esta decisão. Muita gente não se sente bem fazendo pesquisa, porque na pesquisa a exigência é muito grande (...) e nem todo mundo está preparado para isso. Não é problema de incapacidade. Está na índole de cada um. É de ordem pessoal. É um problema de personalidade. É um problema de cabeça. Não desvalorizo aqueles que vão descobrir que não são as melhores pessoas para a pesquisa, mas que são úteis para outras coisas". Em uma das aulas, por exemplo, comentando que alguns alunos não foram bem na prova, disse: "Se estudou muito e não conseguiu, está estudando errado porque quem estuda, aprende. Se não estudou porque não quer ser físico, vá ser comerciante" (Prof. A . Os grifos são meus ). Além do preconceito muito grande, é preciso ressaltar que, muitas vezes, na atitude de não desvalorizar, mas também não valorizar ou até ignorar, está uma atitude velada de desvalorização, que é mais séria do que uma desvalorização declarada.

A indissociabilidade entre Ensino e Pesquisa é vista com nuances diferentes entre eles. Enquanto para uns ela deve estar expressa não só ao nível institucional, mas também individualizada em cada membro do corpo docente, para outros, em decorrência de seus aspectos dicotômicos, os docentes poderiam ter períodos alternados em que ficariam desobrigados de uma das duas atividades, para dedicar-se de maneira mais eficaz a uma delas.

"É ruim para uma instituição de ensino e pesquisa, a pessoa que não faça os dois. As duas têm que ser complementares" (Prof. A).

A segunda posição é corroborada pela afirmação: "De tempos em tempos seria bom preocupar-se só com a pesquisa e ficar livre de dar aula, ou então, poder ficar só com a aula. Ou ainda, separar aqueles que dão aula daqueles que só querem fazer pesquisa. O importante a ressaltar é que se você tem que dar aula, deve fazê-lo muito bem" (Prof. C).

"Publique ou Pereça” (Diamond, 1990, p.48-50) é o título bastante sugestivo de um artigo sobre produção científica, ou como escreveu o autor "é a regra básica da vida acadêmica". Um dos motivos apontados é o crescimento da pesquisa como uma das funções reconhecidas da universidade e outro, "especialmente nas ciências (...) é a competição por garantias de pesquisas" e suas verbas. Critica os pesquisadores que "aprenderam a "engordar" sua bibliografia, aumentando ao máximo o número de publicações derivadas de um único projeto", criando o "MUP, ou menor unidade publicável". Eu acrescentaria a infinidade de trabalhos que os estudantes de Iniciação Científica, Mestrado e Doutorado publicam, 
colocando o nome de seus orientadores. São mecanismos oriundos da pressão por produção científica.

Mais importante, talvez, do que verificar se a pesquisa ajuda no ensino ou vice-versa, é constatar que "o importante é o amadurecimento pessoal do conhecimento humano", como afirmou o professor B. A contribuição que deve ser dada é essa - e ela pode ser feita através de ambos - porque é o resultado de uma postura pessoal que se reflete na conduta profissional. Essa posição de equilíbrio fortalece a consciência de que enquanto se perpetua o discurso e as pessoas permanecem na denúncia, não se busca, concretamente, alternativas de construção da integração real do ensino com a pesquisa e não se realiza o ensino com pesquisa.

Verificando-se as práticas dos professores, no que se refere ao ensino com pesquisa, o professor A, na primeira aula, explicou um experimento com o propósito de convidar os alunos a fazê-lo. "Se algum aluno quiser fazer, poderá ser um trabalho experimental para ser publicado ao mesmo tempo em que aprenderá o assunto. Eu dou o material todo e as condições porque nunca vi este experimento realizado e gostaria de ver". Logo em seguida disse: "vocês já fizeram $70 \%$ das disciplinas do Bacharelado e sabem que suas pesquisas e seu trabalho serão em Física Moderna". O que chamou logo minha atenção foram as referências à pesquisa e publicação, realmente como evidenciou em sua fala.

por Florestan Fernandes:

A síntese quanto ao papel do ensino e da pesquisa é dada

"Seria estúpido pensar-se, atualmente, em separar o ensino da pesquisa. $O$ professor universitário ideal será aquele que tiver treino razoável nas duas direções e que souber combinar, harmoniosamente, papéis intelectuais de professor e de pesquisador. Não obstante, esse requisito ideal não deve ser transferido, sem mais nem menos, para o plano da organização e do crescimento da universidade. Ela deve estruturar-se e desenvolver-se de tal modo que as funções do ensino e as funções da pesquisa não interfiram entre si, debilitando-se $e$ esclerosando-se” (apud Boletim PAE, n.3, dez/95). 


\section{A BUSCA DE SIGNIFICADOS: que caminhos se abrem?}

"Esta profissão precisa de se dizer e de se contar: é uma maneira de a compreender em toda a sua complexidade humana e científica. É que ser professor obriga a opções constantes que cruzam a nossa maneira de ser com a nossa maneira de ensinar, e que desvendam na nossa maneira de ensinar, a nossa maneira de ser".

Antonio Nóvoa

A análise da prática dos professores-pesquisadores do presente estudo, consubstanciada pelas suas opiniões e ações no Bacharelado e na Licenciatura, ensejou condições para compreender aspectos intuídos, mas nem sempre conhecidos ou suficientemente sistematizados da prática docente do professor de Física no ensino superior.

Como já destacado, este estudo não é de avaliação educacional. Também não é sobre professores individualmente. Tampouco se trata de uma intervenção na realidade.

Trata-se de um Estudo de Caso que objetiva compreender a prática docente. "O Estudo de Caso enfatiza o conhecimento do particular. $O$ interesse do pesquisador, ao selecionar uma determinada unidade, é compreendê-la enquanto uma unidade (...) tal como uma pessoa, um programa, uma instituição ou um grupo social”. Portanto, o número de professores do estudo é plenamente satisfatório e representativo desse Estudo de Caso em particular (André, 1992, p.26). 
Reafirmo, ainda, que ao contrário da década de 80 em que os estudos se propunham à denúncia, a década de 90 é marcada pela superação da denúncia inócua e paralisadora, na busca da construção com qualidade. Como diria Sacristán, "a inovação não é mais do que uma correcção de trajectória” (in: Nóvoa, 1991, p.77).

As análises e a sistematização, aqui realizadas, precisam ser encaradas como uma proposta de não fechar resultados. Pela emergência do tema escolhido, pela ausência de investigações sobre ele, pela metodologia utilizada e pela própria postura pessoal/profissional não me cabem soluções ufanistas e nem a prática da denúncia, mas a seriedade do reconhecimento de que se trata de um campo a investigar.

Os pressupostos foram que: os professores não têm a tomada de consciência da epistemologia da prática que desempenham; não foram formados para serem professores e formam-se pedagogicamente no magistério; não socializam suas experiências com os pares, realizando, assim, um trabalho isolado e anônimo; não exercitam a reflexão sobre a sua prática, muito embora reflitam sobre a pesquisa que realizam, não se dando conta de que refletir sobre a prática docente é, também, uma atividade de pesquisa.

No entanto, esses professores encontraram as bases sobre as quais elaboraram/estruturaram o conhecimento docente. Relatei e analisei as conquistas realizadas, por vezes identificando-me com eles e por vezes deles divergindo. Considero que não foi fácil a imersão na sua atuação a fim de compreendê-la, pois a prática da pedagoga, com as possibilidades (apesar das limitações pessoais/profissionais) que são abertas pela formação inicial em educação e perseguidas na formação continuada dificultava, algumas vezes, a isenção da pesquisadora.

Guardando-se os limites da minha própria interpretação na análise dessa realidade pedagógica, proponho-me a tentativa de indicar encaminhamentos futuros, que deverão ser submetidos ao crivo da razão, da estética e da ética de cada profissional professor-pesquisador da área em questão ou de áreas correlatas.

Ressalvo que o presente trabalho objetivou estudar a prática docente e não o processo de construção dessa prática. Para tal, seria necessária a reconstrução da história de vida de professores iniciantes, aposentados e aqueles com certo tempo de experiência a fim de compor o quadro de um estudo longitudinal em que equipes estivessem envolvidas e 
não fosse um trabalho solitário, com as dificuldades implícitas. Além da análise das verbalizações e ações, o conteúdo poderia, também, ser investigado para compor inserções quanto à análise de currículos, assim como poderiam ser ouvidos os alunos. Essas dimensões sugeridas seriam necessárias se a opção fosse pela investigação da construção e não da prática docente propriamente dita, num momento determinado, que foi o recorte feito.

Apesar disso, fiz algumas considerações sobre a trajetória dos quatro professores. Tais considerações foram feitas para estabelecer um diálogo entre a formação passada e a prática atual desses professores, não adquirindo, portanto, papel central na dimensão global do presente trabalho.

O papel do professor do Bacharelado e da Licenciatura e, sobretudo, o papel do educador que tem sob sua responsabilidade futuros bacharéis e licenciados, consiste em que tenha o domínio do conhecimento específico, igualmente o domínio do conhecimento pedagógico e que, fundamentalmente, aprenda com os alunos e os ensine como desenvolver a autonomia intelectual e psicológica.

O que está sendo proposto para atingir essa finalidade informativa e formativa, nos dias atuais em que, ao lado (ou à margem) de uma tecnologia moderníssima convivem seres humanos perplexos, é o ensino e a aprendizagem que favoreçam a reflexão, a capacidade de (re)criação e o gosto por buscar e descobrir o saber não apenas técnicocientífico como também artístico-humanizante.

Os professores precisam socializar, entre os pares que compartilham do mesmo prazer pelo ensino, experiências e reflexões a fim de que possam adquirir segurança naquilo que fazem, promover a autoformação, orientar sua formação continuada sem inseguranças e sem manter-se no anonimato da sua própria sala de aula como se boas experiências fossem obras do acaso.

O conhecimento que o homem tem do mundo que o cerca, seja o mundo físico, o social ou o cultural, está em constante modificação. Observa-se não só seu avanço, na medida em que, continuamente, novas informações são acumuladas, mas principalmente uma alteração persistente na velocidade com que ele ocorre. Em decorrência, nenhum campo do conhecimento é estático e fechado, sendo impossível almejar a possibilidade do fornecimento de uma formação pronta e acabada. Cada vez mais toma-se consciência de que a formação profissional não se encerra na escola, mas continua durante toda atividade da pessoa, obrigando a uma 
atualização permanente. Por esse motivo, formação continuada é um conceito presente nos dias atuais, tanto para a profissão de professor como para outras profissões.

O conhecimento que o professor detém não é fruto da sua formação inicial, apenas. Também não o é da formação continuada, tão somente. $\mathrm{O}$ que o garante é o conjunto de ambas, enriquecido com a sua trajetória, como elabora os valores, como se relaciona com os alunos, seus preconceitos e discriminações, o não-verbal na sala de aula, suas vivências e todo um mundo que deve ser visto e compreendido como conteúdo e cuja execução precisa incorporar a integração, a análise e a reflexão. São fontes significativas em relação à prática pedagógica.

Os quatro professores desse estudo realizaram sua formação inicial e realizam sua formação continuada em instituições públicas do ensino superior. Os professores $\mathrm{A}, \mathrm{C}$ e $\mathrm{D}$ foram formados pela USP, sendo que o professor A formou-se, também, em uma universidade federal do Estado de São Paulo e o B graduou-se em uma universidade federal de outro estado. Eles trabalham na USP, campus de São Carlos.

Como foi seu curso inicial? Qual foi a proposta de formação de seu curso de graduação? Os professores tiveram formação pedagógica?

Um dos professores, embora não questionado a esse respeito, respondeu explicitamente: "fui formado aqui no meio de bacharéis, tudo feito para você formar-se e fazer mestrado e doutorado. Nunca ninguém teve a preocupação de saber se vou dar aula ou não. Mesmo que eu viesse a dar aula aqui, ninguém estava preocupado com isso".

Outro professor, a quem também não foi perguntado, espontaneamente iniciou a primeira entrevista dizendo que "a maioria dos professores do $3^{0}$ grau, principalmente na área de ciências, não tem formação pedagógica. Aprende a dar aula por esforço pessoal, quando gosta. Se não gosta, faz a aula sem compromisso e vai embora. Aprendi com bons professores do Bacharelado e da Licenciatura. Também aprendi na para própria profissão e as teorias pedagógicas me ajudaram. Por conta própria aprendi psicologia do adulto". Defende a ideia de que os bacharéis tenham disciplinas pedagógicas na sua grade curricular, embora reconheça que ambos os cursos apresentam limitações decorrentes, exatamente, da prática pedagógica. 
Nos dois depoimentos podemos ver que não há preocupação institucional pelo desempenho no ensino. As iniciativas ficam por conta do próprio profissional. A proposta de formação ou o currículo 74 das instituições que esses professores frequentaram na graduação e daquela onde trabalham, incluindo-se, ainda, as instituições superiores que formam profissionais que poderão vir a serem professores universitários, é de privilégio absoluto à formação de pesquisadores, com aprofundamento na denominada Física Teórica ou na Física Experimental, portanto na supervalorização dos conteúdos e da pesquisa, sem posicionamento críticoreflexivo quanto ao ensino.

De modo geral, os mesmos procedimentos didáticos característicos da proposta educativa a que estiveram submetidos estão presentes na sua atuação docente: é o verbalismo da aula expositiva, são a formalização e os cálculos, é a transmissão da informação que os alunos devem absorver, é o treinamento por meio de muitos exercícios, é o estudo numa bibliografia que se torna o acervo de cabeceira. Enfim, mais do que o despertar do interesse pela pesquisa é o escravizar-se à pesquisa.

O que temos são cursos onde há cumulatividade do conhecimento, num processo de "transmissão-recepção-reprodução via exposição, exercícios e provas”. “(...) O professor será, então, o bacharel que também ensina (...), formado pelo pesquisador que também ensina” (Mizukami, in: D’Antola, 1992, p. 41).

A formação para ser pesquisador é básica para o profissional das ciências. Igualmente relevante é a formação pedagógica tendo em vista que poderá vir a ser professor universitário. Quando se deparam com a sala de aula, na situação de ensino, alguns deles se perguntam sobre o que estaria errado. Quando isso ocorre, é interessante, pois se questionam e passam a pensar, inquietar-se sobre o como traduzir o que sabem naquilo que o aluno precisa aprender. A insegurança que sentem os faz mencionar repetidas vezes que é preciso ter "domínio técnico". Referem-se ao como selecionar conteúdos, como organizar informações, como levantar o repertório do aluno, que base comum de linguagem pode ser estabelecida para que ele mesmo possa dar sentido ao conhecimento de forma a que não seja, apenas, memorizado e repetido. Infelizmente, porém, nem sempre há essa inquietação e busca com relação ao ensino. É quando,

\footnotetext{
${ }^{74}$ Currículo está sendo entendido como "uma proposta educacional feita por uma instituição, a qual assume a responsabilidade de colocá-la em prática e de avaliar seus resultados". In: Krasilchick, M. Viver a docência. Editorial do Boletim do PAE, n. 2, agosto/95.
} 
então, o professor-pesquisador perpetua uma prática reprodutivista, mecanicista e obrigatória, reservando somente para a pesquisa, a atitude exploratória.

Há, no entanto, outros procedimentos além desses estereotipados? Pude ver que sim. São procedimentos que fazem a prática poder ser diferenciada. Eles conjugam-se, são acrescentados aos acima descritos e não os substituem. Insisto no fato de que os professores não são levados à reflexão - como atitude a ser incorporada - e à análise cuidadosa da sua prática para que o processo de tomada de consciência possa, então, decolar e robustecer-se, ao invés de permanecer amortecido.

Tanto para o Bacharelado como para a Licenciatura, os caminhos que se apresentam pautam-se por concepções de educação, de ensino e de aprendizagem alicerçadas nos "estudos sobre o pensamento do professor", que enfatizam a reflexividade.

$\mathrm{O}$ ato reflexivo contribui, sem dúvida, a auto-avaliação do fazer docente, concorrendo para o aprimoramento da atuação pedagógica.

A prática reflexiva precisa ser conhecida e compreendida para ser exercitada. Isso significa o desvelamento da epistemologia que a sustenta para que não seja uma reflexão às cegas.

Assim, o conhecimento das teorias, das técnicas e das habilidades para a docência é fundamental, mas não garante o bom professor ou o professor reflexivo, se não for acompanhado pelo exercício da reflexão consciente e conscientizadora, pela vivência do processo de reflexão, enfim pelo aprender a reflexão através da experiência.

Habilidade complexa e à qual fomos desacostumados devido ao incentivo ao fazer mecânico, eficaz e eficiente, a reflexão recupera sua importância nesse momento em que novas condições estão sendo exigidas dos cidadãos de um mundo em mudanças aceleradas. $\mathrm{O}$ professor desponta, então, como a figura importante, pois será sua atuação diferenciada que proporcionará, ou não, as condições para o aprendizado e desenvolvimento da habilidade de refletir.

A atuação diferenciada, nos dias atuais, está a requerer o conhecimento teórico-científico, a valorização da experiência, a tomada de consciência epistemológica, a reflexão, a autonomia, a criatividade e a responsabilidade social e intelectual dos professores formadores. A essas condições deve estar amalgamado o comportamento ético em que o 
exemplo pessoal é um dos procedimentos didáticos comprometidos com a formação pessoal e profissional do aluno, conforme foi destacado pelos professores desse estudo.

Os pontos importantes para o docente que forma futuros professores de $2^{\circ}$ ou de $3^{\circ}$ grau são: - ter a conscientização de quais são suas reais posições com relação ao processo de ensino e aprendizagem, ou seja, desenvolver a tomada de consciência da sua prática para que ela não seja alienada, mecânica e reprodutivista; - socializar as experiências pedagógicas com os pares para que seu trabalho seja compartilhado e não isolado e anônimo; - adquirir e exercitar a prática reflexiva como base para a prática docente e análise da mesma; - tornar a realidade concreta em vivência na sala de aula; - desenvolver atitude de parceria com os alunos, que são adultos. Evidentemente, é necessário que tal prática esteja ancorada sobre uma sólida formação pedagógica, subsidiada esta pelos atuais estudos sobre o pensamento do professor, cuja principal abordagem é o pensamento prático reflexivo. Faz-se necessário reafirmar que tanto na formação inicial quanto na formação continuada, a presença de um "lastro institucional $e$ filosófico comum” é imprescindível (Gatti, 1992, p.172).

A opção profissional dos docentes envolvidos foi pela pesquisa e, no caso de um deles, pela extensão. Valorizam, no entanto, a docência e têm atitudes de preocupação e interesse também pelo ensino, condição essa que distingue um físico-professor de outro físico. Há, evidentemente, nuanças próprias a cada um deles no gosto pela pesquisa e pelo ensino, como também dedicação desigual. Assim, o professor A acredita que sua atuação docente será contagiante e exemplo para aqueles que se decidirem pelo ensino, mas na pesquisa deve desenvolver esforço sistemático para formar pessoas que deem continuidade às suas ideias e descobertas para que sejam um prolongamento dele. Como professor, pretende ser tomado como exemplo possível, pelos alunos. Como pesquisador, entende que tem a responsabilidade de criar outros pesquisadores. Os professores $\mathrm{B}$ e $\mathrm{C}$ têm uma dedicação mais equilibrada entre ensino e pesquisa e são muito nítidos os aspectos interessantes quanto à sua docência. Ambos têm um relacionamento bastante satisfatório com os alunos. Aproveitam as suas contribuições, sentem prazer quando são procurados ao término das aulas ou em suas salas, acreditam na conversa aberta e na compreensão humana, imaginam-se no lugar do aluno desde os momentos de preparação das aulas e durante todo o processo, procurando serem facilitadores e preocupando-se com os ganhos significativos na aprendizagem. O professor D tem centralizado sua atuação profissional em ser um disseminador de recursos satisfatórios para o ensino, seja como um professor não-diretivo que leva seus alunos ao contato com recursos educacionais variados, e com a oportunidade de uma instrumentalização 
atualizada, seja como coordenador de projetos para professores e escolas da rede de ensino, por meio do trabalho de extensão. Eu diria, então, que o tripé ensino, pesquisa e extensão está plenamente atendido pelo conjunto dos quatro professores.

Se por um lado, é possível fazer essa constatação, por outro é preciso concluir que esse conjunto não funciona integrado, pois na universidade não existe o trabalho coletivo e cooperativo entre os seus membros docentes.

Esse ponto foi evidenciado no trabalho e é retomado para enfatizar a necessidade de que as trocas, discussões e formas socializadas de melhor encaminhamento e equacionamento das situações educacionais encontrem espaços dialógicos a fim de que o professor não continue isolado nos seus sucessos e insucessos.

O fato da formação nas ciências não estimular a participação, a capacidade de se expressar, de argumentar e, principalmente, de criticar, concorre como um dificultador para o aprendizado desse necessário intercâmbio, ao passo que os cursos das ciências humanas por colocarem ênfase considerável na participação, relacionamento e argumentação, predispõem a uma partilha de ideias e posicionamentos.

Essa é uma vantagem adicional dos cursos de Licenciatura, pois contemplam a formação pedagógica, concorrendo para formar o profissional do ponto de vista técnico como também o educando. Muitas das dificuldades evidenciadas nessa pesquisa encontram suas raízes na ausência de uma satisfatória capacitação pedagógica.

É preciso que se concentrem esforços no sentido de cuidar da formação de professores para o $2^{\underline{0}}$ e $3^{-}$graus, no curso de graduação e também durante a atuação profissional, na formação continuada. No primeiro caso, por meio de formação pedagógica de boa qualidade tanto para alunos da Licenciatura quanto do Bacharelado. No segundo caso, por meio de programas de socialização de experiências entre os pares com ênfase no trabalho coletivo e na prática reflexiva.

Em termos de pós-graduação, aos estudantes das carreiras exatas precisam ser garantidas oportunidades de formação em educação no sentido da construção da interação entre o conhecimento e o modo de fazêlo chegar ao aluno ou ser buscado por ele. Uma proposta é a criação de disciplinas de prática de ensino em que os alunos sejam acompanhados por um professor, no trabalho em disciplinas da graduação a fim de 
aprenderem, exercitando, "uma reflexão mais ampla e aprofundada de problemas educacionais e da Ciência que praticam” (Felicíssimo et al., 1991, p. 122-4).

Outra se refere à continuidade do Programa de Aperfeiçoamento do Ensino (PAE), por possibilitar o desenvolvimento da habilidade didática que falta aos pós-graduandos, por meio da experiência no contato direto com as atividades pedagógicas sob a supervisão de um professor experiente e diferenciado. Por oportunizar a avaliação e o consequente aprendizado das situações de ensino e aprendizagem, interação professor-aluno e aquisição de experiência na vivência com a docência, tem sido considerado um programa fundamental por pós-graduandos que vislumbram a possibilidade de se tornarem professores universitários.

Muito embora o presente Estudo de Caso seja sobre a prática docente no ensino superior e não seja sobre cada um dos professores, é pertinente nesse momento reafirmar que o único professor que fez também Licenciatura no seu curso de graduação, destacou-se no relacionamento com os alunos, na dedicação à docência, no exemplo pessoal e na avaliação. O professor que ministra disciplina na Licenciatura destacou-se na interação com os alunos, na diversificação de estratégias e na dedicação à docência. O professor que trabalha com professores e alunos da rede de ensino, por meio da extensão, destacou-se na autonomia que concede aos seus alunos da Licenciatura e nos recursos e técnicas diversificadas que utiliza e/ou ensina. Dessa forma, permito-me concluir pela positividade do contato, na formação inicial e/ou continuada, com as situações de ensino, com as variáveis pedagógicas, com o aprendizado de psicologia do adulto, enfim com o conhecimento pedagógico.

Resumindo as categorias e os focos já descritos e analisados, constatei que os professores preocupam-se com a preparação de suas aulas, mesmo quando elas são repetidas para turmas subsequentes. $\mathrm{Na}$ execução das aulas, as intervenções dos alunos são geralmente aproveitadas, indicando existir uma flexibilidade entre o planejado e o realizado. As aulas, com exceção de uma das disciplinas pesquisadas, estão estruturadas em torno do modelo expositivo, no qual o professor desempenha o papel principal, cabendo aos alunos, mesmo com suas intervenções e indagações, um desempenho secundário. O formalismo matemático prepondera, apesar de estar sempre precedido da conceituação verbal. Os professores fazem uso de exemplos e situações esclarecedoras dos conceitos abordados nos tópicos ensinados, sendo, entretanto, pouco variada a utilização de recursos e técnicas durante a execução das aulas. Predomina, em três das cinco disciplinas observadas, de maneira 
significativa, o uso de giz e quadro-negro ou mesmo variação da aula expositiva, o que seria possível, por exemplo, pela aula dialogada e outras estratégias pedagógicas nas quais é preciso e possível investir a fim de facilitar a aprendizagem do aluno.

Os professores pesquisados exercem a docência há vários anos, tendo acumulado um conjunto de experiências, algumas positivas e outras frustrantes, que constituem um conhecimento próprio, individual, não socializado com os colegas do mesmo departamento. Três deles tiveram oportunidade de uma iniciação em atividades de ensino, antes de serem contratados como docentes, durante a graduação ou a pós-graduação e defendem essa possibilidade, considerando-a muito positiva.

A avaliação foi o aspecto da prática docente em que os professores externaram sua insegurança, entendendo-a como uma questão numérica com a única finalidade de julgar a aprovação ou não do aluno. Deixaram de contextualizá-la, no processo de ensino, como instrumento de verificação da aprendizagem, de redimensionamento e redirecionamento das atividades programadas. Observei a utilização de situações de verificação de aprendizagem, não entendidas pelo professor como avaliação, por não serem transformadas em nota, que permitem a apreensão das dúvidas individuais e coletivas. Esse é o caso, por exemplo, dos exercícios resolvidos em sala pelos alunos, o que permitia ao professor, percorrendo as carteiras, olhando o que os alunos faziam, ouvindo suas dúvidas, esclarecendo-as individualmente ou coletivamente, sentir o andamento da aprendizagem.

$\mathrm{Na}$ avaliação, por outro lado, devem ser destacadas iniciativas dos professores que podem ser utilizadas em outras situações. É o caso, por exemplo, da introdução nas provas de questões dissertativas, quebrando a monotonia das questões envolvendo apenas cálculos, tão comuns nas arguições de ciências exatas e tecnológicas. Outro exemplo, é a originalidade da arguição oral utilizada por um dos professores, experiência que deve ser aproveitada. Sua técnica de avaliar os alunos aos pares, permitindo que um complete ou complemente a resposta do outro, transforma a avaliação também numa oportunidade de aprendizado.

Dos focos considerados, destaco o relacionamento com os alunos como aquele no qual os professores demonstraram ter maior convicção de suas atitudes. Características pessoais diferenciaram os aspectos de interação com os alunos, de um para outro professor. Suas atitudes em sala de aula, no aspecto relacional, foram coerentes com as suas 
verbalizações. Ao justificarem seus comportamentos apontaram razões afetivas, filosóficas ou utilitárias.

Muito embora a interação professor-aluno seja defendida como elemento muito importante na dinâmica da sala de aula, tanto por professores como por alunos, é preciso atenção no sentido de que a relação interpessoal mais satisfatória seja o corolário de um processo competente de estruturação e tratamento do conhecimento científico e pedagógico, e não seja apenas a tábua de salvação ou a única coisa que se salva no processo.

Os professores não utilizaram expressões que indicassem contato com as teorias pedagógicas. Mesmo demonstrando interesse pelo ensino, suas verbalizações não incluíram ideias veiculadas na literatura pedagógica. Portanto, não há mascaramento nas suas afirmações ou alguma forma de discurso pedagógico desvinculado da prática.

É esperado que os professores sejam competentes e eficazes na prática docente que tem implícita a atitude de proporcionar ao aluno o deslumbrar-se diante da possibilidade de descobrir e conhecer e a perspectiva de possibilitar-lhe aprender a construir seu conhecimento.

Considerando-se que a docência, no ensino superior, está voltada para o aspecto de capacitação profissional e de treinamento técnico, sem muita preocupação com a preparação pessoal, ocorrendo desnível entre essas duas dimensões, faz-se necessário destacar a atitude de dois professores desse estudo (Prof. B e C), com relação à questão do exemplo pessoal, condição que enfatizaram repetidas vezes nas entrevistas e que demonstraram nas suas práticas.

A resposta para essa atitude de considerar o exemplo pessoal como condição fundamental na preparação profissional/pessoal de seus alunos, mencionada pelos dois professores, foi o resultado de elaboração pessoal, ou seja, eles procuraram entender como acontecem as aprendizagens que realizam como pessoas adultas e na sua atuação transferem essa auto-aprendizagem. É o colocar-se no lugar do outro e proceder da forma como gostaria que um professor agisse pessoal e profissionalmente. É o buscar dentro de si, ser humano adulto, o entendimento e as explicações de como se processa a aprendizagem e tornar essa conquista a regra de ouro que aglutina teorias estudadas, experiências e valores.

Essa conquista da experiência pessoal ser utilizada como principal recurso didático, quando ela é fruto do conhecimento teórico, da 
vivência e da tomada de consciência, é um parâmetro bastante profícuo para uma formação continuada intelectualmente autônoma.

A experiência pode ser uma ajuda para o professor que reflete nela e sobre ela, que a socializa com seus pares, que trabalha cooperativamente e que faz do aluno um parceiro. Mas, a experiência também poderá ser um fator dificultador do ensino e da aprendizagem se ela for rígida, estática e não levar em conta os aspectos apontados, como também as mudanças e suas exigências nos dias atuais.

Constatei não existirem atitudes de indagação sistemática sobre as atividades que os professores desenvolvem na docência, em desacordo paradoxal com suas habilidades de pesquisadores.

Os professores utilizam sua formação como pesquisador na motivação e recrutamento de alguns estudantes, considerados os mais capazes, para bolsas de iniciação científica. Em sala de aula, os trabalhos de pesquisa, segundo eles, permitem diversificar os exemplos ilustrativos. Da mesma forma, uma boa formação pedagógica permitiria aplicar alternativas variadas no ensino, incrementar melhores estratégias e promover uma relação professor-aluno mais satisfatória.

A competência em pesquisa não se transfere automaticamente para o ensino, já que são atividades que demandam habilidades distintas. No ensino deve ser mobilizada a capacidade de possibilitar o acesso do aluno a um novo patamar de conhecimento, o que envolve não só o seu domínio, mas principalmente, o modo como ensiná-lo. Essa competência pode ser adquirida pelo pesquisador já formado, pois é uma construção do indivíduo. Entretanto, como a praxe no ensino superior é o exercício da prática docente concomitante com a de pesquisador, deve-se criar mecanismos que possibilitem aos bacharéis e aos pós-graduandos os conhecimentos pedagógicos básicos antes do exercício da docência.

Compartilhar as realizações docentes com os colegas é fundamental. Essa proposta precisa ser encampada pelo departamento ao qual o recém-docente é incorporado, o que envolve uma nova postura sobre a compreensão da importância do ensino, permitindo, em decorrência a superação dos entraves institucionais à eleição também da Licenciatura como papel importante na universidade.

Os professores-pesquisadores centram suas atividades na pesquisa universitária e, portanto, nos assuntos que constituem a linha de pesquisa escolhida por eles. Para pesquisar, desenvolver e produzir 
conhecimentos partem de problemas que lhe são significativos e que os motiva ao trabalho. Aprendem, assim, que para conhecer são necessárias situações problematizadoras, hipóteses e a busca de comprová-las, refutálas ou reformulá-las, extraindo, desse processo, a descoberta e o conhecimento. Como adultos, não aceitariam outro estilo de aprendizagem. No entanto, oferecem resistência e relutam em ver no aluno universitário, o adulto que tem o direito de aprender pelo mesmo processo pedagógico do ensino centrado em situações-problemas, cujo conhecimento ou descoberta se tornaria, então, significativo.

É inadmissível a tese de que só em casos muito excepcionais o mesmo profissional consiga reunir as qualidades de pesquisador e de professor talentoso. Essa concepção enviesada, que apenas serve para a negligência no ensino, por parte de pesquisadores preconceituosos, não tem consistência empírica ou teórica. É possível e até mais coerente, ser competente como professor e como pesquisador, desde que o profissional o queira e se desnude de pré-concepções descompromissadas.

Do ponto de vista institucional é urgente a assunção da valorização da docência em igualdade com a valorização da pesquisa. Se a instituição é também formadora, é preciso que assuma sem meios termos o compromisso com a docência, se não quiser tornar-se uma universidade compromissada com o ensino apenas nos documentos retóricos.

Um ponto muito importante em se tratando da prática docente de professores-pesquisadores é exatamente o fato de que sendo pesquisadores supõe-se que tenham maiores e melhores condições de conduzir um ensino mais investigativo. Não se trata de levar à sala de aula os mesmos temas que pesquisa. Isso, na maioria das vezes não é possível, principalmente se o professor trabalha com disciplinas iniciais do currículo. Trata-se, no entanto, de ter a mesma atitude de inquietação, interesse, busca e reflexão. O professor não pode deixar o pesquisador lá fora quando exerce a docência. O profissional mais indicado para ensinar, aos estudantes, a atitude de busca constante, incansável e perspicaz pelo saber e fazer é o professor-pesquisador ou pesquisador-professor.

Se as salas de aula fossem mais criativas e inovadoras, a habilidade de pesquisar seria uma rotina e seria "constante levantar e testar hipóteses , generalizar, fazer inferências e atribuir significados (...). Professores competentes refletem, experimentam e inventam enquanto ensinam e não apenas aplicam técnicas aprendidas no momento de formação" (Tancredi, 1995, p.437). 
Se os professores refletirem sobre as situações ocorridas em suas salas, existe a possibilidade dessa reflexão conduzir ao reforço de seus comportamentos que resultaram em condições facilitadoras da aprendizagem dos alunos ou à modificação daquelas atitudes julgadas insatisfatórias.

Entretanto, eles não foram formados para a prática reflexiva como parte do conjunto de habilidades necessárias à atuação docente eficaz. Pelo contrário, sua formação privilegiou o direcionamento para a pesquisa e não para a docência. Pode, portanto, parecer utópico sugerir a reflexividade como instrumental que subsidie sua atuação. É claro que esporadicamente, dependendo de suas características pessoais, refletirá sobre aspectos de uma aula cujo desenvolvimento não foi o que planejou e esperava que fosse. Exemplo disso ocorreu durante as entrevistas com os professores B e C.

No entanto, não são essas reflexões pontuais de um professor isolado no conjunto dos docentes que permitirá um saldo significativo na melhoria da prática docente. $\mathrm{Na}$ melhor das hipóteses, tal situação hipotética resultará num avanço também isolado, pois a atitude reflexiva proposta constitui-se num conhecimento que necessita ser adquirido num processo teórico-prático, ou melhor dizendo, prático-teórico já que sua utilização é que necessita ser enfatizada.

Além disso, para que sejam evitados os riscos de uma reflexão pela reflexão que pode decair numa atitude mecânica, reproduzindo e perpetuando a atuação docente ao invés de aprimorá-la, é necessário que as reflexões sejam compartilhadas com os colegas e conduzam comportamentos práticos.

Infelizmente, a atitude de cooperação não é assumida como parte do conjunto de condições necessárias na prática docente. Nas verbalizações dos professores, dois momentos despontaram como frustrantes quanto ao fato da atuação docente ser solitária. Um primeiro, quando um dos professores externou que durante os seus cursos de graduação e de pós-graduação ninguém se preocupava se ele se tornaria docente. Outro professor relatou sua preocupação em deixar escritas suas experiências sobre aulas de laboratório de Física, pelas quais foi responsável numa época anterior, "que depois ninguém lia e se começava tudo do zero". 
Como superar os obstáculos é o desafio que se coloca para os que se preocupam com as questões relacionadas à prática docente: criar condições que favoreçam a atitude de cooperação entre os docentes e possibilitar o exercício de uma prática reflexiva. 


\section{BIBLIOGRAFIA}

ABREU, M.C.T.A. Apoio pedagógico ao professor do ensino superior: uma contribuição. São Paulo : PUC-SP, 1983. Tese (Doutorado em Educação).

ABREU, M.C., MASETTO, M.T. O professor universitário em aula: prática e princípios teóricos. São Paulo : MG Ed. Associados, 1990.

ALONSO, M. Uma tentativa de redefinição do trabalho docente. In:

CONGRESSO DE FORMAÇÃO DE PROFESSORES, Águas de São Pedro. São Paulo, 1994.

ALVES, J.A. O planejamento de pesquisas qualitativas em educação. Cadernos de Pesquisa, São Paulo, n.77, p.53-61, maio 1991.

ALVES, N.(Org.) Formação de professores. São Paulo : Cortez, 1993.

ANDRÉ, M.E.D.A. A contribuição do estudo de caso etnográfico para a reconstrução da didática. São Paulo : FE-USP, 1992. Tese (Livre Docência).

AZANHA, J.M.P. Uma proposta para licenciatura na USP. In: FORUM DA LICENCIATURA, 2, São Paulo : USP, 1991, p. 39-40.

BALZAN, N.C., PAOLI, N.J. Licenciaturas: o discurso e a realidade. Ciência e Cultura, v.40, n.2, p.147-151, fev. 1988.

BARREIRO, A.C.M. et al. Proposta de licenciatura em física. Revista Brasileira de Ensino de Física, v.14, n. 3, p.125-128, 1992.

BAGNATO, V.S. Aulas demonstrativas nos cursos básicos física. Caderno Catarinense de Ensino de Física, v.9, n.3, p.238-244, dez. 1992.

química - Psicologia da educação nas licenciaturas em física, e matemática. Revista Educação e Filosofia. Universidade Federal de Uberlândia, v.8, n.15, p.83-87, jan./jun. 1994.

Modelos de ensino. Revista Educação e Filosofia. Universidade Federal de Uberlândia,v.8, n. 15, 109-115, jan./jun. 1994.

BEHRENS, M.A. A prática pedagógica dos professores universitários: 
perspectivas edesafios frente ao novo século. São Paulo : PUC-SP, 1995.

Tese (Doutorado em Educação).

BERBEL, N.A.N. Metodologia do ensino superior: realidade e significado. Campinas : Papirus, 1994.

BOHOSLAVSKY, R.H. Psicopatologia do vínculo professor-aluno: professor como agente socializante. In: PATTO, M.H.S. Introdução à psicologia escolar. São Paulo : Queiroz, 1985.

BRAGA., M.M. A licenciatura no Brasil: um breve histórico sobre o período 1973-1978. Ciência e Cultura, v. 40, n.2, p.151-157, fev. 1988.

CADERNOS CEDES. Licenciatura 8. São Paulo : Cortez, 1983.

CANDAU, V.M.F. (Coord). Novos rumos da licenciatura. Brasília : INEP, 1987.

CAPPELLETTI, I.F., MASETTO, M.T. (Orgs.). Ensino superior: reflexões e experiência. São Paulo : EDUC, 1986.

CARVALHO, A.M.P. (Coord.). A formação do professor e a prática de ensino. São Paulo : Pioneira, 1988.

CHAGAS, H.L.B. et al. Assistência do monitor e a sua influência na recuperação de alunos. In: SEMINÁRIO DE PESQUISA EM EDUCAÇÃO REGIÃO SUDESTE, 3, Campinas, 1985.

CÔRTES, H.S., HUERGA, S.M.R. Qualidade do ensino superior: a formação pedagógica do professor. Educação, Porto Alegre, v.9, n. 11, p.73-83, 1986.

COUSINET, R. A formação do educador e a pedagogia da aprendizagem. São Paulo : Nacional, 1974.

CUNHA, M.I. A prática pedagógica do bom professor. Campinas (SP) : Papirus, 1994.

CUNHA, M.I., FERNANDES, M.C.B. Formação continuada de professores universitários: uma experiência na perspectiva da produção do conhecimento. In: ENCONTRO NACIONAL DE DIDÁTICA E PRÁTICA DE ENSINO, Goiáz, 1994.

D’ANTOLA, A.(Org.) A prática docente na universidade. São Paulo: EPU, 1992.

DEMO, P. Pesquisa: princípio científico e educativo. São Paulo: Cortez, 1990. Desafios modernos da educação. Petrópolis: Vozes, 1993.

DIAMOND, J. Publique ou pereça. Revista Novaciência, São Paulo, n.6, p.4750, 1990.

DIAS DA SILVA, M.H.F. O professor como sujeito do fazer docente: a prática 
pedagógica nas $5^{\text {as }}$ séries. São Paulo: FE-USP, 1992. Tese (Doutorado em Educação).

EXPERIMENTOTECA: um laboratório completo. Revista Nova Escola. v.10, n. 86, p. 24-27, ago. 1995.

FÁVERO, M.L.A. Da universidade "modernizada" à universidade disciplinada: Atcon e Meira Mattos. São Paulo : Cortez, 1991.

FÁVERO, M.L.A. Produção e apropriação do conhecimento da universidade, In: MOREIRA, A.F.B. (Org.) Conhecimento educacional e formação do professor: questões atuais. Campinas (SP): Papirus, 1994.

FELICÍSSIMO, A.M.P. et al. Prática de ensino de química no $3^{0}$ grau: uma experiência no curso de pós-graduação. Revista Química Nova, v.14, n.2, 1991.

FORESTI, M.C.P.P. Formação pedagógica continuada de docentes na universidade: protótipo de um sistema hipermídia de educação à distância. São Paulo : FE-USP, 1996. Tese (Doutorado em Educação).

FÓRUM de Licenciatura, 2, Universidade de São Paulo, São Paulo, 1991. Anais.

FÓRUM de Licenciatura, 3, Universidade de São Paulo, São Paulo, 1991. Anais.

FÓRUM Universitário: EESC-1968 - Proposta Aprovada, Texto, n. 7. São Carlos: Centro Acadêmico Armando de Salles Oliveira-CAASO, 1973.

FREIRE, P., SHOR, I. Medo e ousadia: o cotidiano do professor. Petrópolis : Vozes, 1990.

FREITAS DE LIMA, E.M. Professores de $3^{0}$ grau com e sem formação pedagógica: relato de suas concepções e vivências. In: REUNIÃO ANUAL DA ANPED, 18, Caxambu, 1995.

GATTI, B. A formação dos docentes: o confronto necessário professor x academia. Cadernos de Pesquisa, n.81, p.70-74, maio 1992.

GODOY, A.S. Professor universitário da área de agronomia: o problema da formação pedagógica. São Paulo : FE-USP, 1983. Dissertação (Mestrado em Educação).

Ambiente de ensino preferido por alunos do terceiro grau: um estudo comparativo. São Paulo : FE-USP, 1989. Tese (Doutorado em Educação).

Ensino universitário: fatores influentes em sala de aula sob a ótica do aluno. In: D’ANTOLA, A. (Org.) A prática docente na universidade. São Paulo: EPU, 1992.

GRIGOLI, J.A.G. A sala de aula na universidade na visão de seus alunos: 
um estudo sobre a prática pedagógica na Universidade. São Paulo : PUC-SP, 1990. Tese (Doutorado em Educação).

GUSDORF, G. Professores, para quê? São Paulo : Martins Fontes, 1987.

HALBWACHS, F. La physique du maître entre la physique du physicien et la physique de l'élève. Revue Française de Pédagogie, v. 33, p.19-29, 1975.

HIPÓLITO, O. Ciência e educação para o futuro. Folha de São Paulo, 29 de março de 1993.

INTEGRAÇÃO Universidade-Escolas de $1^{\circ}$ e $2^{\underline{0}}$ graus. In: ENCONTRO DO SINEC, 1, São Carlos, 1979. Anais. São Carlos : SINEC, 1979.

JOYCE, B. and WEI, M. Models of teaching. New Jersey : Prentice-Hall, 1972.

KOURGANOFF, W. A face oculta da universidade. São Paulo : Ed. UNESP, 1990.

LEMBO, J.M. Por que falham os professores? São Paulo : EPU, 1975.

LIBÂNEO, J.C. Didática. São Paulo : Cortez, 1991.

LIMA, M.L.R. A memória educativa no projeto de formação de professores do ensino superior: o fazer é sobretudo criação. São Paulo : FE-USP, 1995. Tese (Doutorado em Educação).

LORENZONI, L.M. Sobre a formação do professor nos cursos de licenciatura: situação atual e perspectivas futuras. Educação, Porto Alegre, v.13, n. 18, p.19-29, 1990.

LÜDKE, M., ANDRÉ, M.E.D.A. Pesquisa em educação: abordagens qualitativas. São Paulo : EPU, 1986.

LUNA, S. V. Pesquisa, docência e produção. In: D'ANTOLA, A. A prática docente na universidade. São Paulo : EPU, 1992.

MARTINS, M.C.M. A relação ensino/pesquisa na percepção de docentes universitários de física. São Paulo : FE-USP, 1989. Dissertação (Mestrado).

MASCARENHAS, S. Resumo histórico das principais contribuições do Prof. Sérgio Mascarenhas. São Carlos : IFQSC-USP, s.d.

MASETTO, M.T. O professor no ensino superior brasileiro. São Paulo : PUC-SP, 1982. Tese (Doutorado em Educação).

. Em sala de aula de 3o grau, ainda se aprende ...

São Paulo : FE-USP, 1991. Tese (Livre-Docência).

Didática: a aula como centro. São Paulo : FTD, 1994. 
MASETTO, M.T. Pós-graduação e formação de professores para o $3^{0}$ grau.

Revista Ande, n. 21, p.55-60, 1995.

MATTOS, C.L.G. Etnografia crítica de sala de aula: o professor pesquisador e o pesquisador professor em colaboração. In: REUNIÃO ANUAL DA ANPED, 17, Caxambu, 1994.

MIZUKAMI, M.G.N. Ensino: o que fundamenta a ação docente? Rio: PUC, 1983. Tese (Doutorado em Educação).

MOREIRA, A.F.B. (Coord.) Conhecimento educacional e formação do professor: questões atuais. Campinas : Papirus, 1994.

MOSQUERA, J.J.M. Tentativa de caracterização dos sentimentos dos professores nos diferentes graus de ensino. Porto Alegre : PUC-RS, 1976. Tese (Livre-Docência).

NÉBIAS, C.M. O ciclo básico e a democratização do ensino: do discurso proclamado às representações. Tese de Doutoramento. São Paulo : ECA-USP, 1990.

NÓVOA, A. (Coord.) Profissão professor. Porto : Porto Editora,1991.

(Coord.) Os professores e a sua formação. Lisboa : Dom Quixote, 1992a.

(Coord.) As organizações escolares em análise. Lisboa : Dom

Quixote, 1992b.

. (Org.) Vidas de professores. Porto : Porto Editora, 1992c.

OLIVEIRA, M.R.N.S. Didática: ruptura, compromisso e pesquisa. Campinas : Papirus, 1993.

PAGOTTO, M.D.S. Formação e atuação: um estudo sobre representações de professores. São Carlos (SP) : UFSCar, 1988. Dissertação (Mestrado).

PAOLI, N. O princípio da indissociabilidade do ensino e da pesquisa: elementos para uma discussão. Caderno Cedes, n.22, p.27-52, 1988.

PATTO, M.H.S. Introdução à psicologia escolar. São Paulo : Queiroz, 1985.

PERALTA, J.J. Modernização dos currículos de graduação. In: FÓRUM DA LICENCIATURA, 2, São Paulo, USP, 1991. p.31.

PERDIGÃO, AL.R.V., BUENO, M.B.O, TANCREDI, R.M.S.P. O professorpesquisador e o pesquisador-professor: uma proposta para a sua formação. São Carlos : UFSCar, 1992. (mimeo.).

PERRENOUD, P. Práticas pedagógicas, profissão docente e formação: perspectivas sociológicas. Lisboa : Dom Quixote, 1993.

PIMENTEL, M.G.B. O professor em construção. Campinas (SP) : Papirus, 1994. 
RODRIGUES, A., ESTEVES M. A análise de necessidades na formação de professores. Porto : Porto Editora, 1993.

SÃO JOSÉ, H.B. Disciplinas básicas do ensino superior: (des)encontros e (des)conhecimentos. Porto Alegre : UFRS, 1990. Dissertação (Mestrado).

SERBINO, R.V., BERNARDO, M.V.C. (Orgs.) Educadores para o século XXI: uma visão multidisciplinar. São Paulo : Ed.UNESP, 1992.

SEVERINO, A.J. A formação profissional do educador: pressupostos filosóficos e implicações curriculares. Ande, n.17, p. 29-40, 1991.

TANCREDI, R.M.S.P. A formação do professor nos cursos de licenciatura da área de ciências na UFSCar: uma análise da questão sob a ótica dos licenciados. São Carlos : UFSCar, 1995. Tese (Doutorado em Educação).

TANURI, L.M. et al. Articulação entre bacharelado e licenciatura na UNESP: uma proposta. Didática, São Paulo, v. 19, p.39-45, 1983.

TERRAZAN, E.A. Perspectivas para a inserção da física moderna na escola média. São Paulo : FE-USP, 1994. Tese (Doutorado em Educação).

VALLE FILHO, M.R. Caminhos da licenciatura: presente do futuro. São Paulo : Jornal da USP, 17 a 23/02/1992, p.2.

VANIN. V.R. et al. Licenciatura em busca de outros caminhos, Revista Adusp, São Paulo, v.1, n.1, dez. 1994.

VASCONCELOS, M.L.M.C. O profissional liberal na docência de $3^{\mathbf{0}}$ grau: uma proposta de atualização pedagógica. São Paulo : Universidade Mackenzie, 1994. Tese (Doutorado em Educação).

VELLOSO, J. Pesquisa educacional na américa latina: tendências, necessidades e desafios. Cadernos de Pesquisa, São Paulo, n. 81, p.5-21, maio 1992.

WEBER, S. A produção recente na área da educação. Cadernos de Pesquisa. São Paulo, n. 81, p.22-32, maio 1992.

WITTER, J.S. USP/50 anos: registro de um debate. São Paulo : Reitoria da Universidade de São Paulo, 1984.

ZABALZA, M.A. Diários de aula: contributo para o estudo dos dilemas práticos dos professores. Porto : Porto Editora, 1994. 


\section{Documentos:}

Anuário Estatístico USP 1993- Relatório de Atividades.São Paulo: USP, 1994.

Anuário Estatístico USP 1994- Relatório de Atividades. São Paulo: USP, 1995.

Boletim Interno LEF/IFSC/USP.

Catálogo dos Cursos de Graduação da USP - 1995.

Diário Oficial da União, 12/02/92, Seção I, p.1709.

Diário Oficial do Estado, Seção I, São Paulo, 104(91), 19/05/94, p.23

Diário Oficial do Estado, Seção I, São Paulo, 14/04/95.

Diário Oficial do Estado, Seção I, São Paulo, 105(130), 11/07/95, p.32.

Estatutos da USP.

PAE - Boletim do Programa de Aperfeiçoamento de Ensino. São Paulo: USP, no 1 , maio/1995.

PAE - Boletim do Programa de Aperfeiçoamento de Ensino. São Paulo: USP, no 2, agosto/1995.

PAE - Boletim do Programa de Aperfeiçoamento de Ensino. São Paulo: USP, no 3, dezembro/1995.

PAE - Boletim do Programa de Aperfeiçoamento de Ensino. São Paulo: USP, no 4, abril/1996.

Portaria IFQSC n⿳0 529/86

Portaria IFQSC n⿳0 966/91.

Portaria MEC n⿳0 273 de 11/02/92.

Portaria IFQSC n $\mathrm{o}$ 1355/93.

Portaria IFQSC n⿳0 $1386 / 94$.

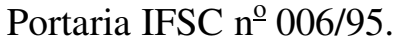

Processo USP $\mathrm{n}^{\mathrm{0}}$ 15868/80.

Processo USP $n^{0}$ 174/85.

Processo USP n⿳0 88-1-1168-54-0.

Processo USP n⿳⺈ 90-1-795-54-4.

Processo USP n⿳0 92-1-624-54-7.

Relatório da Comissão Permanente de Avaliação - USP, 1992.

Relatórios Internos CDCC/IFQSC/IFSC/USP.

Regimento do CDCC, 1995.

Resolução USP n ${ }^{\circ}$ 1974/80.

Resolução USP n ${ }^{0}$ 3731/90.

Resolução USP n⿳0 4077/94. 


\begin{abstract}
ANEXO 1
O roteiro para a primeira entrevista focalizou os seguintes aspectos: 1 - Como o professor encara a interação professor-aluno? Os elementos que se procurou extrair/observar foram: como é a sua interação com os alunos; o que faz para facilitá-la; tem preocupação com o clima em sala-deaula; dirige-se aos alunos no decorrer da aula; ao fazer uma pergunta dá tempo para que pensem e respondam; como percebe se os alunos estão compreendendo o assunto?

2 - O que o professor pensa a respeito da aprendizagem dos alunos? Elementos: preocupa-se com a compreensão pelos alunos; o cumprimento do programa o perturba; quais são seus objetivos de aprendizagem?

3 - Como o professor planeja seu curso? Elementos: prepara cada aula; faz plano detalhado ou esboço; quanto tempo em média utiliza para preparar as aulas; como executa o curso planejado; se ministra o curso em anos subsequentes, repete as aulas da maneira como havia programado na primeira vez; escolhe para cada unidade as noções que serão trabalhadas, o modo de trabalhar e a correspondente avaliação; organiza o próprio texto?

4 - Como o professor age se um aluno sugere uma pista interessante? Elementos: segue-a sem se perturbar, se ela foge ao que tinha planejado; não a segue; não deixa "passar em branco", mas volta rápido para a sua programação.

5 - Que tipo de técnicas e recursos o professor programa para utilizar em aula? Elementos: de quais técnicas de aula gosta mais e quais utiliza com mais frequência; que recursos realmente utiliza?

6 - Como o professor concebe a avaliação? Elementos: como avalia os seus alunos; tem dificuldades para avaliar?

7 - Houve modificação na atividade do professor no decorrer dos semestres e anos letivos da sua vida profissional? Em que aspectos?

8 - O que o professor penso sobre a relação ensino-pesquisa?
\end{abstract}




\section{ANEXO 2}

O roteiro para a segunda entrevista aplicada aos professores focalizou os seguintes aspectos:

1) Você gosta do que faz? Seu trabalho o satisfaz?

2) Você gosta de dar aula? Por quê?

3) Que relação você faz entre seu trabalho e realização/crescimento pessoal?

4) Que relação você faz entre seu trabalho e cidadania?

5) Que relação você faz entre seu trabalho e participação no desenvolvimento do país e da história?

6) Fale sobre seus conflitos, angústias, limitações, dificuldades que aconteceram ou acontecem na sua prática docente.

7) Fale sobre seus sonhos e idealizações de professor.

8) Fale sobre suas realizações e aprendizagens no exercício da sua profissão.

9) Preparar cursos com o mesmo zelo e compromisso como se prepara artigos para publicação, significa estar assumindo a docência com compromisso? Comente.

10) Como você construiu sua prática docente?

11) Quais as competências que os professores deveriam ajudar os alunos a desenvolver?

12) Que tipos de conhecimentos e de habilidades permitem aos professores desempenhar o seu trabalho eficazmente?

13) Quais os fatores mais determinantes para que professores se tornem bem sucedidos?

14) Os professores tomam micro decisões inesperadas que têm um "tom" pessoal no ensino que ministra e portanto na aprendizagem e atitudes dos alunos. Você concorda? Discorda? Por quê?

15) Qual o eixo norteador de seu trabalho como formador de professores? Como procede para concretizar este eixo condutor?

16) E no seu trabalho como formador de bacharéis?

17) Quais suas expectativas quanto aos seus alunos? E quanto à sua disciplina?

18) Quais são suas expectativas quanto a você como docente?

19) Que indicadores você utiliza para analisar sua prática a fim de compreender como e porquê suas atuações foram bem ou mal sucedidas? 
20) As constatações e aprendizagens do professor em exercício deveriam resultar em benefícios para a formação inicial? De que modo poderia ser feito?

21) Pede aos alunos para avaliarem seu curso? Leva em conta as opiniões deles, modificando o que lhe parece procedente?

22) Que papel desempenha a intuição na prática docente?

23) Todas as vezes em que modificou alguma coisa na sua prática, você o fez motivado, principalmente, por quais fatores? 